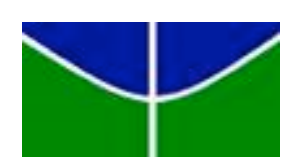

Universidade de Brasília - UnB

Instituto de Ciências Humanas - IH

Departamento de História - HIS

Programa de Pós-Graduação em História - PPGHIS

Tese de Doutorado

\title{
A REPRESSÃO POLÍTICA NA FRONTEIRA URUGUAIANA - PASO DE LOS LIBRES NO FINAL DA DÉCADA DE 1970
}

SABRINA STEINKE

Brasília 


\section{A REPRESSÃO POLÍTICA NA FRONTEIRA URUGUAIANA}

- PASO DE LOS LIBRES NO FINAL DA DÉCADA DE 1970

Tese apresentada ao Programa de PósGraduação em História, do Departamento de História, do Instituto de Ciências Humanas da Universidade de Brasília como parte dos requisitos para obtenção do grau de Doutora em História.

Orientador: Prof. Dr. Francisco Fernando Monteoliva Doratioto. 
Universidade de Brasília - UnB

Instituto de Ciências Humanas - IH

Departamento de História - HIS

Programa de Pós-Graduação em História - PPGHIS

Tese de Doutorado

SABRINA STEINKE

\section{A REPRESSÃO POLÍTICA NA FRONTEIRA URUGUAIANA} - PASO DE LOS LIBRES NO FINAL DA DÉCADA DE 1970

Tese apresentada ao Programa de Pós-Graduação em História, do Departamento de História, do Instituto de Ciências Humanas da Universidade de Brasília como parte dos requisitos para obtenção do grau de Doutor em História.

Orientador: Prof. Dr. Francisco Fernando Monteoliva Doratioto Banca Examinadora:
Prof. Dr. Francisco Fernando Monteoliva Doratioto - Orientador PPGHIS/HIS/IH/UnB

Prof. Dr. Daniel Barbosa Faria - Membro PPGHIS/HIS/IH/UnB

Prof. Dr. José Otávio Guimarães - Membro

UnB

Profa. Dra. Ione de Fátima Oliveira - Membro

UnB

Prof. Dr. Douglas Antonio Rocha Pinheiro - Membro UFG

Prof. Dr. Carlos Eduardo Vidigal - Suplente

$\mathrm{UnB}$

Aprovado em 27/04/2016. 
Lorenzo Ismael Viñas, presente!

Jorge Oscar Adur, presente!

Cristina Gloria Fiori de Vino, presente! 
Para que não se esqueça, para que nunca mais aconteça! 


\section{AGRADECIMENTOS}

Faça uma lista de grandes amigos

Quem você mais via há dez anos atrás

Quantos você ainda vê todo dia

Quantos você já não encontra mais [...]. ${ }^{1}$

Há 11 anos ingressei no curso de História. Nesta jornada - graduação, mestrado e doutorado, a lista de grandes amigos que se fez é imensa. Agradeço os amigos que eu mais via há dez anos atrás: Edison Brito, Marilene Ribeiro, Lilian, Tati e Danilo. E, principalmente, ao Igor Lisboa, a quem conheci na graduação e que me acolheu generosamente durante uma parte do doutorado, em sua casa: seu apoio foi fundamental para esta jornada. Muitíssimo obrigada!

Muito obrigada aos meus grandes amigos que não vejo todos os dias, que já não encontro mais (ou não tanto quanto gostaria); esses, ausentes, são os mais presentes, presentes na minha vida, e presentes de vida: Daniela Queiroz Campos, João Júlio Gomes dos Santos Júnior, Paula Rafaela da Silva, Mariana Flores da Cunha Thompson Flores, Andrius Noronha, Inara Bezerra de Sousa, Jaime Valim Mansan e Glaci Braga.

\section{[...] Faça uma lista dos sonhos que tinha Quantos você desistiu de sonhar! [... $]^{2}$}

O sonho que tinha eu não desisti de sonhar, e somente foi possível realizar pelo apoio e generosidade financeira de duas pessoas muito especiais: Douglas e Aletéia Soares, que custearam passagens aéreas para que eu pudesse assistir as aulas, semanalmente, em Brasília, mesmo morando em Porto Alegre, no primeiro semestre do curso de Doutorado - além de me liberarem do trabalho para assistir às aulas e realizar atividades acadêmicas. Mais que a ajuda financeira, vocês sonharam junto comigo e tornaram possível algo que não estava ao meu alcance naquele momento. Muito obrigada!

Do mesmo modo, agradeço ao Programa de Pós-Graduação em História (PPGHIS) da Universidade de Brasília (UnB) por me acolher. Aproveito para agradecer a todos os funcionários do Programa, sempre solícitos e generosos, em especial, Rodolfo e Jorge. Gostaria de agradecer à Coordenação de Aperfeiçoamento de Pessoal de Nível Superior

\footnotetext{
${ }^{1}$ MONTENEGRO, Oswaldo. A lista. In: Ao vivo 25 anos: disco 1. 2004.

${ }^{2}$ Ibidem.

${ }^{3}$ NGiderTENEGRO, Oswaldo. A lista. In: Ao vivo 25 anos: disco 1. 2004.
} 
(CAPES) - agência de fomento que possibilitou a realização desta pesquisa, pela bolsa no Brasil e no exterior. 
[...] Quantos amores jurados pra sempre

Quantos você conseguiu preservar $[\ldots]^{3}$

Os amores jurados não são para sempre, porque: al poner condición se evapora el amor. Agradeço ao amor sem amarras, sem cobranças, livre e intenso, que preservei junto com Oscar Camilo Silva Evangelista, o melhor companheiro que poderia ter encontrado. Principalmente por não jurar! Por se comprometer, me apoiar, me ajudar e me acompanhar desde o começo do Mestrado até o final desta jornada. Camis, obrigada! "É óbvio".

[...] Onde você ainda se reconhece

$\mathrm{Na}$ foto passada ou no espelho de agora? $[\ldots]^{4}$

Agradeço aos professores do PPGHIS/UnB: ao Professor Dr. Francisco Fernando Monteoliva Doratioto, pela acolhida e imensa generosidade. Ao Professor Dr. Pablo Pozzi, que me recebeu na Universidad de Buenos Aires. Pela compreensão e dedicação: Dra. Filomena, Dr. Arthur e Dr. Henrique. Pela contribuição acadêmica e pela amizade: Profa. Dra. Cléria Botelho e Profa. Dra. Eloísa Barroso. Aos professores do curso de Mestrado: Dr. Helder Volmar Gordim da Silveira, Dr. Jurandir Malerba, Dr. René Ernaini Gertz e a Dra. Janete Silveira Abrão. Vocês são onde me reconheço e quem eu busco ser enquanto historiadora e cidadã. Aos professores: Dr. Daniel Barbosa Faria; Dr. José Otávio Guimarães; Dra. Ione de Fátima Oliveira; Dr. Douglas Antonio Rocha Pinheiro; Prof. Dr. Carlos Eduardo Vidigal, que aceitaram participar da banca. Muito obrigada!

[...] Hoje é do jeito que achou que seria Quantos amigos você jogou fora? [... $]^{5}$

Nunca é do jeito que achamos que seria! Não joguei fora amigos! Agreguei! À toda comunidade colombiana em Brasília, principalmente aos moradores da "comarca": Tiga, David, Milton, Juan Pablo e Edson. Levo vocês no meu coração, para sempre! Aos colegas da Comissão de Anistia: Sarah, Carol, Elton, Andrei, Oadir, Jenny, Angélica, David, Jandyra, Simone Botelho e Bel Leite, que foram maravilhosos quando eu mais precisei. Aos amigos e colegas da UnB: Ramon Barroncas, Clerismar Longo, Mariana Yokoya, Michelle Nunes de Morais, Maura Leal, Gilson Brandão, Júlia Orioli, Mário Rosa, Maria Lúcia Pardi, Artur Santos, Walkiria Oliveira, Juan David Figueroa, Vitória Fox e Dirceu Marchini.

\footnotetext{
${ }^{3}$ MONTENEGRO, Oswaldo. A lista. In: Ao vivo 25 anos: disco 1. 2004.

${ }^{4}$ Ibidem.

${ }^{5}$ Idem
} 
$\mathrm{Na}$ empreitada que foi mudar de cidade e de Estado, conheci pessoas maravilhosas, que ajudaram a tornar o cotidiano mais leve. Aos queridos: Flávio Salvini, Rafael Silveira, Joás Barbosa e, em especial, Victor Ribeiro. Às maravilhosas: Isabela Costa, Fernanda MacGinity e Rosália Olivieri - garotas, vocês são sensacionais! Muito obrigada! A família da Inara, que me acolheu como se eu fosse parte dela: obrigada! Nestas idas e vindas, agradeço a família do Oscar Camilo Silva Evangelista, que sempre me recebeu muito bem e me acolheram carinhosamente inúmeras vezes: obrigada, sra. Cleide Silva e sr. Oscar de Oliveira Evangelista!

Aos grandes amigos conquistados em Buenos Aires, especialmente ao Rodrigo, ou melhor, Rodri, dos cosas: gracias y muchas gracias por tanta felicidade compartilhada. Aos amigos do Tango Casa Carlos Gardel: maravilhosos! Los extraño mucho! Aos meus amados Nati e Saulo: vocês estarão sempre no meu coração.

Ao Dante Flávio da Costa Reis Júnior, meu grande amigo, e que é a minha família em Brasília. Pela amizade em Buenos Aires, pela enorme generosidade e empatia. Pelas alegrias e tristezas compartilhadas: Dantchê, gracias, gracias y gracias.

\section{[...] Quantos mistérios que você sondava Quantos você conseguiu entender? [...] $]^{6}$}

Aos funcionários de todos os arquivos pesquisados. São inúmeros! Não teria como nomear sem esquecer de muitos. Às pessoas que desde sempre colaboraram com minhas pesquisas: Francisco Amorim, Nilson Mariano, Ivan Cláudio Marx, Aluízio Ferreira Palmar, André Saboia Martins, entre tantos outros que compartilharam documentos, emprestaram livros, indicaram leituras: muito obrigada! Seguirei sondando mistérios.

\section{[...] Quantas pessoas que você amava}

Hoje acredita que amam você? ${ }^{7}$

Por fim, e mais emblemático, àqueles que eu amo e que me amam em qualquer condição. Meus pais Valter e Sueli, meus irmãos Susi, Nicio e Valdir, aos meus sobrinhos e minha cunhada Juliana! Minha irmã "emprestada" Bete Dorneles, que cuida dos meus quando eu não estou e quando estou também. Muito obrigada!

\footnotetext{
${ }^{6}$ MONTENEGRO, Oswaldo. A lista. In: Ao vivo 25 anos: disco 1. 2004.

${ }^{7}$ Ibidem.
} 



\section{RESUMO}

A presente Tese tem como tema a repressão política na fronteira localizada entre as cidades de Uruguaiana (Brasil) e Paso de los Libres (Argentina) no final dos anos 1970, em especial, as conexões repressivas estabelecidas entre as ditaduras do Brasil e Argentina na referida região. Tem-se uma análise dos casos de sequestro/desaparecimento ocorridos na fronteira Uruguaiana-Paso de los Libres-Corrientes, esta última, na Argentina. A hipótese aqui empreendida é deque a cooperação repressiva na fronteira Uruguaiana-Paso de los Libres no final dos anos 1970, fazia parte do aparato da Operação Condor, e que as atividades operacionais ligadas ao contrato repressivo do Condor ocorreram em Uruguaiana e Paso de los Libres. A História do Tempo Presente é a fundamentação argumentativa da Tese e sua chave analítica é a Doutrina de Segurança Nacional, que propiciou a instalação do terrorismo de Estado implementado pelas ditaduras do Brasil e da Argentina e que repercutiram nos demais países do Cone Sul. Para tanto, a pesquisa está estruturada em três eixos, a saber: o primeiro contempla uma discussão acerca dos golpes no Cone Sul e de como se deu a articulação repressiva internacional da Operação Condor; o segundo aborda a composição da fronteira Uruguaiana-Paso de los Libres acerca de sua história e as atividades formais de conexões binacionais que ocorriam na aduana entre esses dois países; e, o terceiro, compreende as atividades clandestinas ocorridas nesta fronteira, quem circulava e como se estruturou a repressão na aduana nela existente. A Tese conta com seis capítulos, que compreendem desde a implantação das ditaduras de segurança nacional no Brasil e na Argentina, as colaborações entre estas, a fronteira objeto de estudo e os casos de sequestro/desaparecimento analisados, quais sejam: Lorenzo Ismael Viñas, Jorge Oscar Adur, Margarita Mengol Villas de Moroz e Cristina Gloria Fiori.

Palavras-chave: Operação Condor. Fronteira Brasil-Argentina. Conexões repressivas. Repressão em Uruguaiana. Repressão em Paso de los Libres. 


\begin{abstract}
This thesis has as subject the political repression on the frontier between Uruguaiana and Paso de los Libres, in the end of the 1970's, specially the repressive connections among the dictatorships of Brazil and Argentina on this borderland. We analyzed cases of kidnapping/disappearance that occurred on this border between Uruguaiana - Rio Grande do Sul - Brazil and Paso de los Libres - Corrientes - Argentina. Our hypothesis is that repressive cooperation on the frontier was part of the Condor Operation, and we believe that operational activities linked to the repressive contract of the Condor occurred in both Uruguaiana and Paso de los Libres. The History of Present Time is the argumentative foundation of the thesis, and the analytical key is the National Security Doctrine, which provided the establishment of the State Terrorism implemented by the dictatorships of Brazil and Argentina with large repercussion on Southern Cone. To comply with that goal, we structured the thesis in three parts: the first discusses about those political overthrows on the Southern Cone and how the international repressive articulation of the Condor Operation happened; the second examine the history and the formal activities of bi-national connections that took place on the custom between those countries; the third is about the surreptitious activities that occurred on this border, who circulated and how the repression on that custom was structured. This thesis has six chapters that embrace the implementation of the National Security Dictatorships in Brazil and Argentina, the collaboration among them, the frontier as matter of study and the cases of kidnapping/disappearance of Lorenzo Ismael Viñas, Jorge Oscar Adur, Margarita Mengol Villas de Moroz and Cristina Gloria Fiori.
\end{abstract}

Keywords: Condor Operation; Brazil-Argentina frontier; Repressive connections; Repression in Uruguaiana; Repression in Paso de los Libres. 


\section{RESUMEN}

Esta tesis tiene como objeto la represión política en la frontera entre las ciudades de Uruguayana (Brasil) y Paso de los Libres (Argentina) a finales de 1970, en particular, las conexiones entre las dictaduras represivas de Brasil y Argentina en esa región. Se ha realizado un análisis de los casos de secuestro/desaparición que se produjo en la frontera UruguayanaPaso de los Libres-Corrientes, esta última en Argentina. La hipótesis aquí es llevado a cabo la cooperación represiva fronteriza Uruguayana-Paso los Libres a finales de 1970. Formó parte del aparato de la Operativo Condor, y que las actividades operacionales relacionadas con el contrato represivo del Condor se produjo en Uruguayana y Paso de los Libres. La Historia del Tiempo presente es el razonamiento argumentativo de la tesis y su clave de análisis es la Doctrina de Seguridad Nacional, que permitió la instalación del terrorismo de Estado implementado por las dictaduras de Brasil y Argentina y que tuvo repercusiones en otros países del Cono Sur. Por lo tanto, la investigación se estructura en tres ejes, a saber: la primera contempla una discusión de los golpes en el Cono Sur y cómo se dio la articulación represiva internacional de la Operación Condor; el segundo trata de la composición de la frontera Uruguayana-Paso de los Libres, su historia y las actividades formales de conexiones binacionales que se producen en la aduana entre los dos países; y la tercera comprende las actividades clandestinas que han ocurrido en esta frontera, quién circulaba y como se estructuro la represión ocurrida en la Aduana. La tesis consta de seis capítulos, que van desde la implementación de las dictaduras de seguridad nacional en Brasil y Argentina, la colaboración entre ambos, la frontera objeto de estudio y los casos de secuestro/desaparición analizados, a saber: Lorenzo Ismael Viñas, Jorge Oscar Adur, Margarita Mengol Villas Moroz y Cristina Gloria Fiori.

Palabras clave: Operativo Condor. Frontera Brasil y Argentina. Conexiones represivas. Represión en Uruguayana. Represión en Paso de los Libres. 


\section{LISTA DE FIGURAS}

Figura 1 - Mapa das prisões e centros de interrogatórios no Rio Grande do Sul..........

Figura 2 - Mapa demonstrativo acerca das distâncias de Uruguaiana até as capitais de Argentina e Uruguai, e da capital do Rio Grande do Sul - Porto Alegre

Figura 3 - $\quad$ Imagem da inauguração da ponte em 21 de maio de 1947.

Figura 4 - Mapa demonstrativo da região estudada nesta Tese: Uruguaiana-Paso de los Libres.

Figura 5 - Juzgado Federal de Paso de los Libres............................... 106

Figura 6 - $\quad$ Telegrama enviado da Embaixada de Buenos Aires para o Brasil.............. 114

Figura 7 - Vista da casa principal da estância La Polaca, Juzgado Federal argentino,

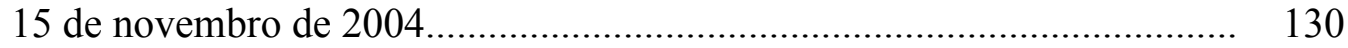

Figura 8 - Júlio Héctor Simon - "El turco Julían”........................... 153

Figura $9-\quad$ Lorenzo Ismael Viñas............................................ 157

Figura $10-\quad$ Ficha de Lorenzo Ismael Viñas.................................... 160

Figura 11 - Padre Jorge Oscar Adur............................................................................. 163

Figura 12 - Lista de passageiros do ônibus em que Jorge Oscar Adur viajava quando

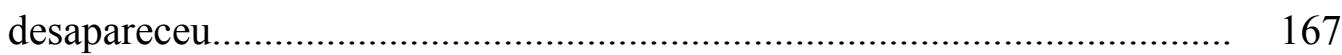

Figura 13 - Foto publicada no Diário Página 12 ..................................................... 178 


\section{LISTA DE ABREVIATURAS E SIGLAS}

\begin{tabular}{|c|c|}
\hline ACNUR & - Alto Comissariado das Nações Unidas para Refugiados \\
\hline ALN & - Aliança Libertadora Nacional \\
\hline B 601 & - Batalhão 601 \\
\hline Cadhu & - Comisión Argentina de Derechos Humanos \\
\hline CEPDOC & - Centro de Pesquisa e Documentação Histórica Contemporânea do Brasil \\
\hline CIE & - Centro de Informações do Exército \\
\hline CIEx & - Centro de Informações ao Exterior \\
\hline $\mathrm{CNV}$ & - Comissão Nacional da Verdade \\
\hline CONADEP & - Comissión Nacional sobre Desaparecimiento de Personas \\
\hline D 123 & - Destacamento 123 \\
\hline DOI-CODI & $\begin{array}{l}\text { - Destacamento de Operações de Informações do Centro de Operações de } \\
\text { Defesa interna }\end{array}$ \\
\hline DINA & - Direción de Inteligencia Nacional \\
\hline DOPS & - Departamento de Ordem Política e Social \\
\hline DSN & - Doutrina de Segurança Nacional \\
\hline EGP & - Ejército Guerrillero del Pueblo \\
\hline ERP & - Ejército Revolucionario del Pueblo \\
\hline EUA & - Estados Unidos da América \\
\hline FAB & - Força Aérea Brasileira \\
\hline FAL & - Fuerzas Argentinas de Liberación \\
\hline FAP & - Forças Armadas Peronistas \\
\hline FAR & - Forças Armadas Revolucionárias \\
\hline FGV & - Fundação Getúlio Vargas \\
\hline GEL & - Guerrilla para el Ejército de Liberación \\
\hline IBGE & - Instituto Brasileiro de Geografia e Estatística \\
\hline $\mathrm{M} 3 \mathrm{G}$ & - Marx, Mao, Marighella e Guevara \\
\hline MDB & - Movimento Democrático Brasileiro \\
\hline MERCOSUL & - Mercado Comum do Sul \\
\hline MNR & - Movimento Nacionalista Revolucionário \\
\hline MRE & - Ministério das Relações Exteriores \\
\hline MRT & - Movimento Revolucionário Tiradentes \\
\hline
\end{tabular}




$\begin{array}{ll}\text { OBAN } & \text { - Organização Bandeirantes } \\ \text { PRT } & \text { - Partido Revolucionario del Pueblo } \\ \text { PVP } & \text { - Partido por la Victória del Pueblo } \\ \text { PCB } & - \text { Partido Comunista Brasileiro } \\ \text { SIDE } & - \text { Servicio de Informaciones del Estado } \\ \text { SNI } & - \text { Serviço Nacional de Informações } \\ \text { SOPS } & - \text { Seções de Ordem Política e Social } \\ \text { VAR- } & - \text { Vanguarda Armada Revolucionária } \\ \text { Palmares } & \\ \text { VPR } & - \text { Vanguarda Popular Revolucionária }\end{array}$




\section{SUMÁRIO}

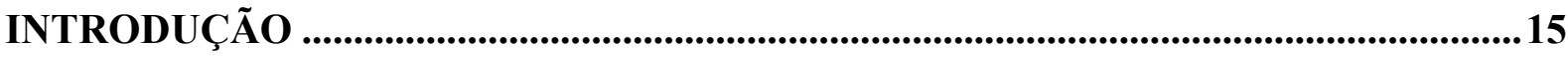

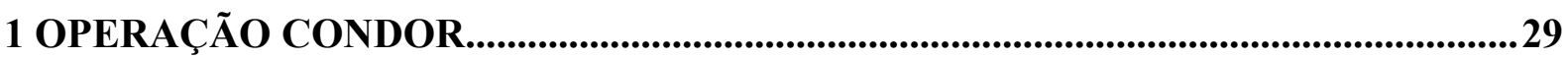

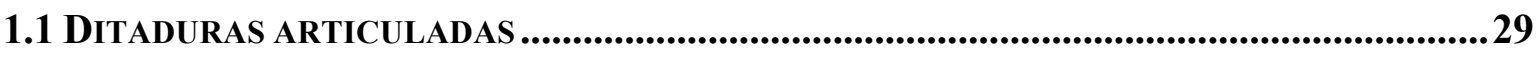

1.1.1 Ditaduras no Cone Sul nos anos 1970 _............................................................31

1.1.2 Terrorismo de Estado e segurança nacional no Cone Sul ....................................35

1.2 Brasil, ARgentina E ChILE: AS ditaduras de SEguranÇa naCiOnAL ....................42

1.2.1 O Brasil e seus 21 anos de ditadura ....................................................................42

1.2.2 A experiência chilena..................................................................................46

1.2.3 A "reorganização" argentina............................................................................................4 47

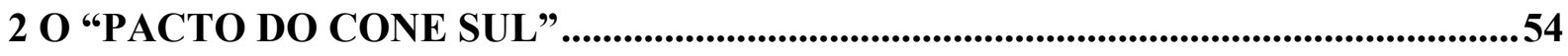

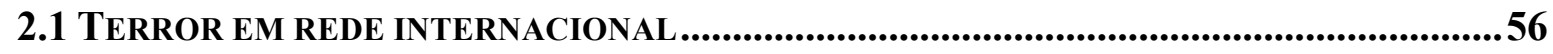

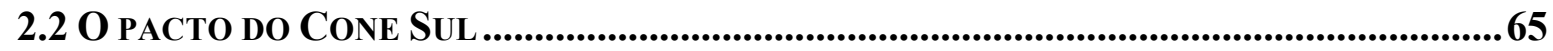

2.3 O Rio Grande do SUl na OPERAÇão Condor .....................................................68

3 FRONTEIRA E CONEXÕES NA/DE FRONTEIRA.....................................................75

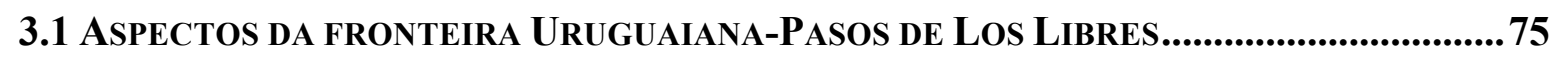

3.2 Uruguaiana e Pasos de Los Libres.........................................................................8

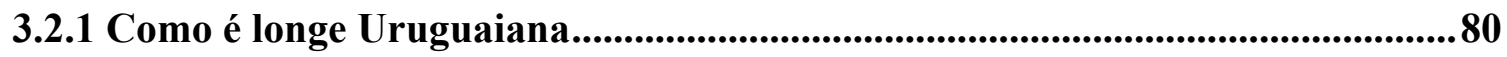

3.2.2 Paso de lós Libres: a passagem dos 108 .......................................................83

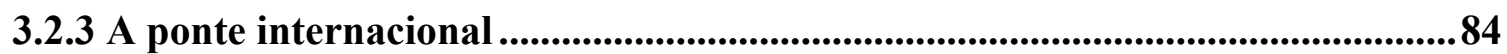

3.3 FRONTEIRA, FRONTEIRIZAÇÃO, FRONTEIRA MANEJADA, FRONTEIRA IDEOLÓGICA ...89 4 CONEXÕES NA FRONTEIRA URUGUAIANA-PASO DE LOS LIBRES.................98

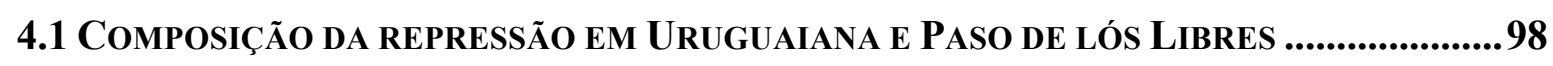
4.2 O CRUZE DE FRONTEIRA - EL CRUZE DE LA FRONTERA: COTIDIANOS FRONTEIRIÇOS 103

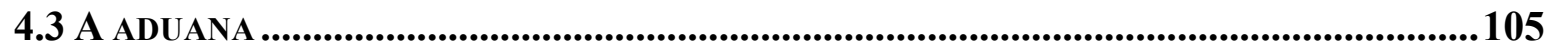

4.3.1 Aduana Uruguaiana-Paso de los Libres no final dos anos 1970 ......................107

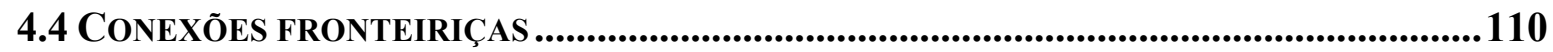

4.4.1 Fugas, prisões e conexões fronteiriças ...........................................................113

4.4.2 Jacques de Souza Coimbra e a rede repressiva ..............................................114

4.4.3 Cônsul Ney Corrêa: ocorrências pontuais na aduana.....................................121 5 ESTRUTURA REPRESSIVA NA FRONTEIRA URUGUAIANA-PASO DE LOS 
5.1 A PRISÃo CLANDESTINA E O TRÂNSITO DE "INIMIGOS" ..........................................129

5.1.1 La Polaca, la chacra.........................................................................................130

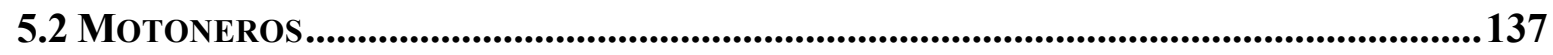

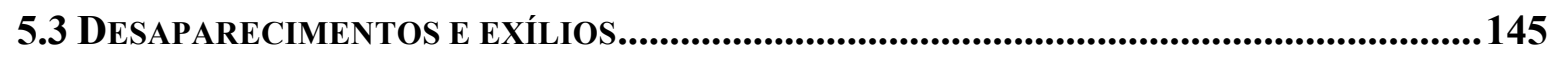

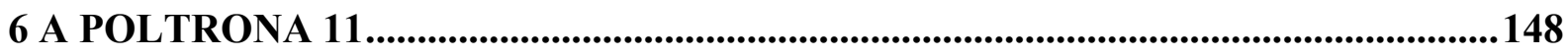

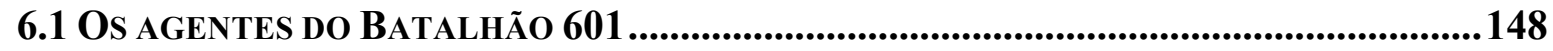

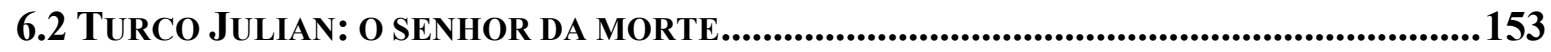

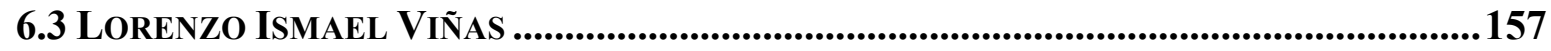

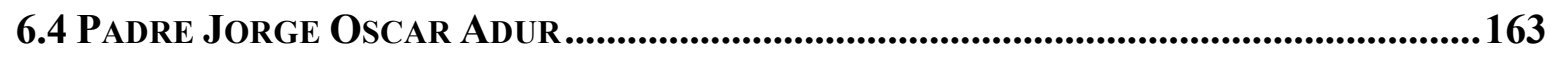

6.5 Margarita e CRistina: SEqUestro binacional.............................................172

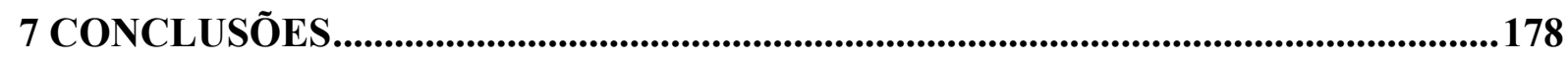

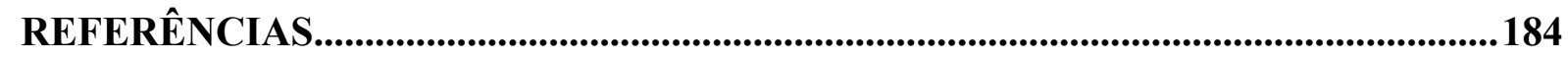




\section{INTRODUÇÃO}

Em dezembro de 2004, durante minha graduação em História, fiz estágio na Secretaria de Turismo do Estado do Rio Grande do Sul. Meu local de trabalho era uma sala na Aduana integrada do Brasil e da Argentina. Durante o estágio tive contato direto com os Gendarmes ${ }^{8}$, e eram recorrentes as conversas acerca das atividades ocorridas alhures naquele local. Por meio de relatos desses agentes argentinos, tomei conhecimento de que a sala ao lado da qual eu trabalhava teria sido local de tortura durante os anos do Processo de Reorganização Nacional $^{9}$. E que muito perto da Aduana teria funcionado uma prisão clandestina, a famigerada estância La Polaca.

Desde então, procurei alcançar os acontecimentos naquela sala, daquela prisão, daquela cidade, daquela fronteira. Esta Tese é uma reverberação dessa busca, com o objetivo de trabalhar de maneira mais densa a questão de repressão fronteiriça, de conexões repressivas ali perpetradas, e de sequestros e desaparecimentos ali ocorridos, e as articulações internacionais que permitiram a ocorrência desses casos. Dessa forma, a Tese sintetiza minha trajetória acadêmica iniciada na graduação.

Em junho de 1980, Lorenzo Ismael Viñas desapareceu na fronteira entre Uruguaiana e Paso de los Libres. Na mesma data e local, o padre Jorge Oscar Adur também ali desapareceu. Ambos partiram de Buenos Aires no dia 26 de junho, com passagens para o Brasil, mas nunca chegaram ao destino. Em 1979, uma cidadã espanhola e uma argentina foram vítimas de um sequestro em Uruguaiana, executado por policiais brasileiros e argentinos. Margarita Mengol

\footnotetext{
${ }^{8}$ A Gendarmeria Nacional Argentina, foi criada em 1938, durante a presidência de Roberto M. Ortiz, com o objetivo de consolidar limites internacionais e garantir a segurança das populações nas regiões mais afastadas do centro do país. Seus primeiros "postos" se localizaram com intuito de guardar as fronteiras, seus componentes tem formação militar e são subordinados do Ministério de Segurança. Informações: http://www.gendarmeria.gov.ar/historia/index.html acesso em: 11 de janeiro de 2012.

${ }^{9}$ O Processo de Reorganização Nacional é a denominação usada pelos militares para o golde militar de março de 1976 na Argentina. As forças armadas prometiam com o Proceso uma regeneração social e política. Intervindo não apenas nas instituições, mas sim tendo a nação como objeto de reconstrução. Usavam em seu discurso de maneira corriqueira as palavras: "extirpar, erradicar, reestructurar". Prometiam assim livrar a sociedade argentina de todo o "mal" que a contaminava, prejudicando seu desenvolvimento. O diagnóstico oferecido pelas forças armadas afirmava que esse "mal" estava incutido na própria sociedade e era a natureza dos conflitos existentes. Esse mal se chamava subversão. Para dar conta dessa empreitada, a junta militar que orquestrou o golpe não mediu esforços a fim de garantir que seus projetos fossem desenvolvidos. A preocupação com o elevado número de militantes no país fez com que se estruturasse um aparato repressivo sem precedentes na Argentina. Nesse sentido, esse regime militar foi pioneiro. Cf.: NOVARO, Marcos; PALERMO, Vicente. A Ditadura Militar argentina 1976-1983: do golpe de Estado à restauração democrática. São Paulo: Editora da Universidade de São Paulo, 2007. p. 26; O’DONNELL. Guillermo. Contrapuntos: ensayos escogidos sobre autoritarismo y democratización. Buenos Aires: Paidós, 2004. p. 101.
} 
Villas de Moroz - a espanhola - escapou e vive na Espanha. A argentina Cristina Gloria Fiori de Vino está desaparecida desde então.

Estes e outros casos que estão presentes nos capítulos três e quatro, e seu contexto são objeto de análise da presente Tese. Me propuz tratar dessas citadas atividades repressivas ocorridas na fronteira de Uruguaiana e Paso de los Libres, com intuito de demonstrar como essa região foi palco de conexões de cunho repressivo no âmbito da Operação Condor. Registra-se que nessa fronteira também se estabeleceram redes de solidariedade às vitimas da repressão, no entanto o objeto desta Tese é unicamente as citadas conexões repressivas políticas. A pergunta principal desta Tese é: qual foi o caráter da cooperação repressiva na fronteira entre Uruguaiana e Paso de los Libres? De que forma a repressão influenciou o cotidiano de fronteira? Os acontecimentos repressivos colaborativos, registrados na fronteira entre Uruguaiana e Paso de los Libres no final dos anos 70, foram atividades repressivas pontuais, ou estavam imbricadas nas atividades da Operação Condor?

Em 1979, o General Manuel Contreras ${ }^{10}$, em entrevista para a revista Ercilla, afirmou: "Lógicamente, como todo servicio de que nace, tuvimos contactos con servicios de inteligencia amigos, los cuales nos ayudaron en forma permanente y a los que, con el tiempo, ayudamos nosotros también. ",1

A chamada Operação Condor, considerada por Contreras como um "acordo", constituiu uma rede de colaboração entre organismos de informação e/ou repressão de seis países latinos americanos: Chile, Brasil, Paraguai, Uruguai, Argentina e Bolívia. Tal rede de colaboração foi oficialmente formalizada em 1975, sendo esses organismos ligados aos seus respectivos Estados que, nesse período, estavam sob a gestão de regimes ditatoriais - com exceção da Argentina, que sofreu o seu mais recente golpe militar em março de 1976.

A Operação Condor foi organizada e sistematizada para formalizar as colaborações repressivas, que já eram efetuadas de forma ocasional entre os citados países antes de sua oficialização no Chile em $1975^{13}$. Estavam presentes neste ato agentes da Bolívia, Chile, Uruguai, Paraguai e Brasil. ${ }^{14}$

\footnotetext{
${ }^{10}$ Juan Manuel Guillermo Contreras Sepúlveda, nasceu em 04 de maio de 1929 no Chile, filho mais velho de um oficial do Exército chileno ficou orfão de mãe aos 6 anos. Foi criado pelas tias e a avó, aos 14 anos ingressou na escola militar, em 1966, já oficial, foi professor de inteligência na Academia de Guerra, em 1967 finalizou o curso de luta antiguerrilheira na escola Forte Benning em Virgínia Estados Unidos. Foi chefe da polícia política chilena a Direción de Inteligencia Nacional - DINA durante o governo de Augusto Pinochet. Era um dos homens mais "temidos" e poderosos do Chile nos seus anos ditatoriais, é tido como o articulador e gerenciador da Operação Condor.

${ }^{11}$ MARTORELL, Francisco. Operación Cóndor: el vuelo de la muerte. Santiago: LOM Ediciones, 1999. p. 18.

12 Ibidem, p. 23.

${ }^{13}$ Como o "I Seminário de Polícia sobre a Luta Antisubversiva no Cone Sul" realizado em fevereiro de 1974 em Buenos Aires, contou com representantes dos seis países envolvidos na formalização da Operação Condor.
} 
A Operação Condor foi, no geral, estruturada em três fases: a primeira, de troca de informações - em princípio, a distribuição de listas dos "subversivos" procurados entre os países participantes; a segunda, de operações e ações na América Latina; e a terceira teria como foco operações fora do território latino americano. O termo "operações", no âmbito desse sistema repressivo, significava, entre outras atividades: sequestros, torturas e desaparecimentos. Importante salientar que essas fases não são separadas - elas ocorriam de forma simultânea, ou seja, ao mesmo tempo em que se trocava informação, pessoas eram capturadas através das operações do Plano Condor.

$\mathrm{O}$ objeto de pesquisa desta Tese está diretamente ligado às atividades repressivas da Operação Condor em sua segunda fase - as operações na região fronteiriça do sudoeste do Brasil, em Uruguaiana. De forma específica, este trabalho aborda ocorrências repressivas políticas na fronteira entre Uruguaiana-RS e Paso de los Libres-Corrientes, no final dos anos 1970, durante os mais recentes regimes ditatoriais vivenciados no Brasil (1964-1985) e Argentina (1976-1983).

O tema de análise dessa Tese está contemplado no que podemos chamar de "passado que dói" 15 , já que "inegavelmente, os crimes produzidos pelas ditaduras de segurança nacional têm sido historicamente escamoteados pelos responsáveis daquelas ditaduras e pelos governos posteriores em conluio ou coniventes com aqueles"16, são ocorrências em aberto, feridas não curadas. Conforme Romero, os estudos do passado que dói são de difícil análise para o historiador, por estarem inseridos em "questões conflitivas, que dividem a opinião, quem trata de compreender costuma ser acusado de justificar, ou de colocar em questão verdades que são centrais para as crenças" ${ }^{17}$. É tarefa hercúlea para o historiador tratar do coetâneo; as pressões diretas e indiretas exigem um esforço acadêmico apurado, visto que se trata de um campo repleto de tensões políticas e de memória.

Cf:: http://www.viomundo.com.br/politica/luiz-claudio-cunha-as-garras-do-brasil-na-operacao-condor.html acesso em 08 de julho de 2012 às $10 \mathrm{~h}$. No desenvolvimento do primeiro capítulo essas articulações estão mais detalhadas.

14 Disponível em: http://www.viomundo.com.br/politica/luiz-claudio-cunha-as-garras-do-brasil-na-operacaocondor.html acesso em 08 de julho de 2012 às $10 \mathrm{~h}$.

${ }^{15}$ ROMERO, Luis A. A memória, o historiador e o cidadão. A memória do Proceso argentino e os problemas da democracia. TOPOI, v. 8, n. 15, p. 9-23, jul./dez. 2007.

${ }^{16}$ PADRÓS, Enrique S. A história e a memória confiscada: o tempo presente e as ditaduras de segurança nacional. In: Clínicas do testemunho: reparação psíquica e construção de memórias. Porto Alegre: Criação Humana, 2014. p. 202.

${ }^{17}$ ROMERO, op. cit., p. 11. 
Os estudos que envolvem questões que estão em aberto, ou seja, que não são processos encerrados, como o dos desaparecimentos do último ciclo de ditaduras no Cone Sul, ecoam no presente. As feridas abertas do "passado que dói” exigem uma análise que compreenda o uso político dessas histórias e memórias, ou dos esquecimentos e omissões. A proposta conceitual do "passado que dói” é uma viável alternativa para compreender esses processos históricos de dores não sanadas, de ocultações e de disputas políticas, pois apresenta uma análise para além de maniqueísmos, de bem e mal.

$\mathrm{O}$ historiador que pretende tratar desses temas tem de ter em conta alguns critérios. A escolha de uma versão crítica, complexa e matizada, oferecendo lições menos evidentes do que o ponto de vista: quem eram os amigos ou quem eram os inimigos? Mas de compreensão mais abrangente de circunstâncias reais. Portanto, um historiador que trata do "passado que dói” é um historiador que se propõe analisar diversas facetas de um processo em aberto. Desse modo a análise desta Tese está inserida no "passado que dói", quando analisa a repressão na fronteira Uruguaiana - Paso de los Libres sob diversas perspectivas, desde o cotidiano fronteiriço, o modo de viver na fronteira, como se estruturou a repressão em ambas margens do rio Uruguai, a formação destes municípios até os casos de sequestro/desaparecimento que ocorream na região.

É importante ressaltar que os estudos do "passado que dói” estão inseridos, também, nos estudos sobre o Tempo Presente. Trata-se de um entendimento para além de corte cronológico próximo da atualidade, mas sim, de processo histórico que está sendo afetado pelo coetâneo, como o dos casos analisados nesta Tese.

A discussão dessa agenda tem como inspiração a forma que Vezzetti aponta em seus estudos sobre o Tempo Presente: "la recuperación de la experiencia pasada se abre hacia un contexto presente, móvil y conflictivo" ${ }^{\prime 18}$. Esse contexto é ainda mais polêmico ao abordar um passado que trata de "feridas produzidas pela impunidade e pela ausência de esclarecimentos, sobretudo nos casos de desaparecimento"19. Para Sarlo, que alerta sobre os "sinistros" que se tornam públicos, o conhecimento que circula é ao mesmo tempo excessivo e escasso; corremos o risco da utopia de informação total, de encontrar todas as vítimas e todos os carrascos, porém é salutar que saibamos: é impossível a totalidade acerca de processos

\footnotetext{
${ }^{18}$ VEZZETTI. Hugo (a). Pasado y presente: guerra, dictadura e sociedade en la Argentina. Buenos Aires: Siglo Veintiuno Editores, 2009. p. 15.

${ }^{19}$ PADRÓS, Enrique Serra. Como el Uruguay no hay... Terror de Estado e Segurança Nacional - Uruguai (1968-1985): do Pachecato à Ditadura Civil-Militar. Porto Alegre: UFRGS, 2005. Tese, Doutorado em História - UFRGS. Porto Alegre, 2005. p. 16.
} 
históricos, já que nenhuma história poderá reconstruir tudo, mas a utópica busca pelo saber nos serve como um horizonte e uma advertência. ${ }^{20}$

Ao trabalhar com questões e com um contexto que "dói" do passado recente, o pesquisador precisa estar atento às tentações ideológicas e políticas que vão ser colocadas diante dele durante toda a elaboração da pesquisa. Segundo Romero, os historiadores possuem mais de uma alma, somos ao mesmo tempo historiadores e cidadãos, e essas "almas" estão em conflito, pois quando tratamos do "passado que dói” somos atores comprometidos e analistas, defendemos valores e praticamos a relativização do saber. ${ }^{21}$

Cabe ao historiador buscar fugir da armadilha de querer "julgar o passado em vez de tentar explicá-lo" ${ }^{22}$. A tarefa do pesquisador consiste em:

Levantar dados, relacionar fatos, explicar processos e avaliar os resultados dessas operações mentais fundamentam uma constante contribuição da história à produção de conhecimento científico e, conseqüentemente, à sociedade. Fora disso, corresponde a outras estâncias dessa sociedade desempenhar certas tarefas e assumir determinadas responsabilidades como a de querer julgar. ${ }^{23}$

Como se portar enquanto historiador ao tratar de um tema que está muito próximo a ele? Robert Frank afirma que os historiadores do presente debatem com suas próprias fontes e trabalham, de certa forma, se vigiando, estabelecendo uma cumplicidade com o objeto, a qual é, ao mesmo tempo conflituosa. É esse diálogo que pode tornar nosso trabalho fecundo, pois historiadores têm o papel de buscar compreender o que há de representativo, ou seja, que informações contidas nos depoimentos são esclarecedoras para acontecimentos tão próximos - devemos explicar, selecionar e hierarquizar. ${ }^{24}$

Analisando um processo histórico recente e traumático, como o aqui proposto, a pesquisa é peculiar, uma vez que em geral seus protagonistas estão inseridos em um campo de disputa - política, ideológica e de memória. Cabe ao historiador, quando se defronta com esses debates, buscar uma explicação plausível para uma agenda marcada por lacunas. As explicações que podemos oferecer sobre os processos do Tempo Presente, podem - e geralmente são -, provisórias, porém isso não desmerece o esforço para que se dê sentido para

${ }^{20}$ SARLO, Beatriz. Tempo presente: notas sobre a mudança de uma cultura. Rio de Janeiro: José Olympio, 2005. p. 42.

${ }^{21}$ ROMERO, Luis A. A memória, o historiador e o cidadão. A memória do Proceso argentino e os problemas da democracia. TOPOI, v. 8, n. 15, p. 9-23, jul./dez. 2007.

${ }^{22}$ PADRÓS, Enrique Serra. Como el Uruguay no hay... Terror de Estado e Segurança Nacional - Uruguai (1968-1985): do Pachecato à Ditadura Civil-Militar. Porto Alegre: UFRGS, 2005. Tese, Doutorado em História - UFRGS. Porto Alegre, 2005. p. 16.

${ }^{23}$ Ibidem, p. 42-43.

${ }^{24}$ FRANK, Robert. Questões para as fontes do presente. In: CHAUVEAU, Agnès; TÉTART, Philippe (Org.). Questões para a história do presente. Bauru, SP: EDUSC, 1999. p. 116. 
"cenários ainda desordenados ou com lacunas" ${ }^{25}$ é uma sistematização, organização e passo importante para que esses emaranhados de acontecimentos sejam debatidos e ampliados, a intenção é poder "constituir um ponto de partida mais qualificado para futuras análises". ${ }^{26}$

Quando se trabalha com ditaduras militares, é notória a dificuldade no acesso às fontes. Isso pode tornar-se um grande problema para o pesquisador. A acessibilidade aos documentos dos arquivos - quando esses existem - é praticamente nula. Perde-se, assim, muita informação que poderia ser de utilidade na elaboração do quadro explicativo do processo histórico analisado. Como consequência da interdição de arquivos, há a necessidade de buscar informações em diferentes fontes, para tentar reconstruir e explicar esse passado. Essa dificuldade, porém não impede que se realize um trabalho com rigor metodológico, ficando particularmente explicitado, nesse caso, o caráter provisório do conhecimento historiográfico.

Nesta Tese a questão de fontes é mais sensível, pois as ocorrências repressivas produziram-se em mais de um país e cada qual tem suas espeficidades quanto à geração de documentos durante os respectivos períodos repressivos e acesso a esses registros.

Ainda quanto à dificuldade de acesso as fontes, Hobsbawm afirma que esta é uma limitação óbvia para o historiador coetâneo. A dificuldade de acesso aos documentos é o menor dos problemas, pois nesse quesito o pesquisador do seu próprio tempo não está pior, ou melhor amparado, que um historiador de um século distante. Ao menos temos a perspectiva de mais cedo ou mais tarde ter disponíveis acervos que no momento da pesquisa estavam inacessíveis, ao passo que as lacunas nos registros passados mais longínquos, em maioria, são permanentes. $^{27}$

O historiador, ao reconstruir episódios da história, tem a missão de montar um quebracabeça. Pela especificidade dos casos estudados e do tema abordado nessa Tese, foi necessário durante a pesquisa buscar diversos arquivos e agregar uma diversidade de documentos. O substrato documental nessa Tese é plural: além de documentos produzidos por organismos vinculados ao aparato estatal, fazem parte do acervo utilizado cartas, livros produzidos tanto pelo Estado quanto por militantes contrários ao sistema imposto -, fotografias, relatos e testemunhos, em sua maioria de cunho judicial. Esse material, arrolado durante os anos de pesquisa, formam o construto desse trabalho.

\footnotetext{
${ }^{25}$ PADRÓS, Enrique Serra. Como el Uruguay no hay... Terror de Estado e Segurança Nacional - Uruguai (1968-1985): do Pachecato à Ditadura Civil-Militar. Porto Alegre: UFRGS, 2005. Tese, Doutorado em História - UFRGS. Porto Alegre, 2005. p. 40.

${ }^{26}$ Ibidem, p. 40.

27 HOBSBAWM, Eric. O presente como História. In: HOBSBAWM, Eric. Sobre história. São Paulo: Companhia das Letras, 1998. p. 253-254.
} 
A análise será detalhada, principalmente quanto a relatos e depoimentos, conforme proposto por Sarlo:

\begin{abstract}
O que um testemunho entrega a seus leitores? Histórias verdadeiras. Como elas são construídas? Com detalhes verdadeiros. Tudo pode ser falso num testemunho, menos os detalhes. [...] Quando alguém se lembra com tantos detalhes das coisas menores, ficamos certos de que os fatos maiores estão sendo reproduzidos com exatidão diante dos nossos olhos. ${ }^{28}$
\end{abstract}

A fronteira Uruguaiana-Paso de los Libres foi uma das regiões mais significativas das conexões repressivas perpretadas durante o último ciclo de ditaduras do Cone Sul. Advogo a descentralização que a historiografia apresenta dos temas da repressão, elencando e hierarquizando territórios, quantativamente, como mais importantes que outros, principalmente se tratando de uma localidade distante dos grandes centros. Dessa forma, a fronteira é vista como zona de contato, de tensão e protagonismo.

Quando abordamos repressão e crimes violentos praticados pelo Estado, e se tratando de uma época em que não vivemos, imediatamente alguns pensam que são ocorrências distantes, geograficamente e temporalmente, salvo quando há um familiar ou conhecido vitimado pelo terrorismo de Estado. Quando comecei as pesquisas nessa temática, me surpreendeu o quanto as pessoas se espantavam quando ouviam que Uruguaiana-RS foi cenário de ocorrências repressivas durante a mais recente ditadura. Em realidade, as pessoas, em geral, acreditavam que nem o Rio Grande do Sul teria sido palco de repressão desse porte. Acredito que isso seja uma reverberação da política de memória adotada no Brasil: a do esquecimento.

Durante décadas foi imposto um condicionamento do silêncio, isso culminou em, "uma atitude social de rumores, sussurros e indiferença, todas formas de expressão de uma sociedade que, em parte, virou as costas ou preferiu não ouvir o que aqueles sobreviventes nunca deixaram de 'bradar', nem que fosse ao vento". ${ }^{29}$ A questão é que, para a surpresa de boa parcela da sociedade e, de certa forma, de conhecimento relativamente difundido entre a comunidade acadêmica, o Rio Grande do Sul foi estratégico para a repressão, principalmente quanto às conexões repressivas com seus vizinhos Uruguai e Argentina:

\footnotetext{
${ }^{28}$ SARLO, Beatriz. Tempo presente: notas sobre a mudança de uma cultura. Rio de Janeiro: José Olympio, 2005. p. 152

${ }^{29}$ PADRÓS, Enrique S. A história e a memória confiscada: o tempo presente e as ditaduras de segurança nacional. In: Clínicas do Testemunho: reparação psíquica e construção de memórias. Porto Alegre: Criação Humana, 2014. p. 194.
} 
O fato do Rio Grande do Sul possuir fronteira comum com o Uruguai e a Argentina, respectivamente, delegou, por parte do regime, um papel de baluarte da defesa nacional; o aparato repressivo local incorporou essa preocupação com afinco. Paradoxalmente, seu território constituía, para a oposição, uma espécie de corredor ou uma rota estratégica para conectar a resistência interna com aquela organizada no exterior. $^{30}$

A temática discutida nessa Tese está em efervescência, por diversos fatores: os documentos sobre as articulações no Cone Sul que foram liberados pelos Estados Unidos da América; a repercussão das atividades da Comissão Nacional da Verdade (CNV); e os processos judiciais acerca da Operação Condor em andamento na cidade Buenos Aires e em Roma. Além disso, é frequente o aparecimento de notícias sobre a Operação Condor na mídia. Acredito que reconstruir esses episódios, com rigor historiográfico, e debater o tema por meio de novas perspectivas, é contribuir de forma revigorada para a historiografia acerca desse período, ainda repleto de lacunas - assim como acredito que debater a fronteira UruguaianaPaso de los Libres é latente para a percepção dos vários sentidos que esse local pode acomodar conforme o processo histórico.

O caminho até as fontes utilizadas nessa pesquisa está vinculado à minha trajetória acadêmica. Durante os anos de pesquisa fui organizando um arquivo, de diversas instituições. Graças à Lei de Acesso à Informação (Lei no 12.527 de 2011, que começou vigorar em maio de 2012), foi possível verificar as informações já publicadas sobre esses casos, bem como agregar novos conhecimentos acerca desses acontecimentos. Ademais, além das fontes inéditas sobre os casos, também foi localizado no Arquivo Nacional um livro da organização dos Montoneros ${ }^{31}$, datado de 1979, que trata do Pacto do Cone Sul, utilizado no segundo capítulo dessa Tese. Importa salientar, que mesmo após a efetivação da Lei de Acesso à Informação, grande parte dos documentos do período ditatorial não estão disponíveis para consulta, devido o processo de digitalização.

Minhas pesquisas foram realizadas no Brasil e Argentina, iniciadas ainda no mestrado no Juzgado Federal de Paso de los Libres, de onde se originou um relevante - e inédito acervo acerca da repressão em Paso de los Libres e Uruguaiana, composto por documentos do processo movido para averiguação das atividades ocorridas na fazenda La Polaca, com o desmembramento deste processo em 2011, os arquivos foram separados em diversas províncias, desta forma, sou a única com o arquivo completo. No Arquivo Nacional, foram

\footnotetext{
${ }^{30}$ PADRÓS, Enrique Serra; MARÇAL, Fábio Azambuja. O Rio Grande do Sul no cenário da coordenação repressive de segurança nacional. In.: PADRÓS... [et. al.] Ditadura de Segurança Nacional no Rio Grande do Sul (1964-1985): história e memória. 2. ed. rev. e ampl. Porto Alegre: Corag, 2010. v. 3. p. 37.

31 "Diante dos acordos Videla-Figueiredo o PACTO DO CONE SUL". Fundo SNI - Documento AC_ACE_16680_81.
} 
realizadas quatro coletas. No acervo do Itamaraty, uma importante documentação sobre atividades de monitoramento e investigação ocorridas na fronteira, objeto dessa Tese, foi coletada. No Rio Grande do Sul, estive no Arquivo do Museu de Comunicação Social Hipólito José da Costa, bem como tive acesso aos documentos do Movimento Justiça e Direitos Humanos. Durante meu período de estágio sanduíche em Buenos Aires, fiz pesquisas no acervo da Comissión Nacional sobre Desaparecimiento de Personas (CONADEP), na Biblioteca Nacional Argentina, Centro de Documentación e Investigación de la Cultura de Izquierdas en Argentina (CEDINCI) e Centro de Estudios Legales y Sociales (CELS).

Historiadores que se propõe pesquisar períodos de violência praticada por instituições estatais, precisam construir um acervo próprio, buscar o máximo possível de informações para que se possa compreender o objeto de pesquisa proposto. Para escrever, nesta Tese, sobre a repressão em Uruguaiana e Paso de los Libres, foi necessária extensa pesquisa o que repercutiu na construção de um acervo quantitativamente significativo. Esses documentos permitiram obter respostas, o que era de se esperar, mas nem por isso deixou de surpreender, também revelaram informações que, por sua vez, remetem a novas perguntas.

Portanto, às perguntas apresentadas no projeto inicial deste Doutorado acrescentaramse outras durante as pesquisas em fontes primárias. Outra consideração relevante é a de que a documentação referente à repressão, embora tenha sido escamoteada por muito tempo aos pesquisadores, o que induz a crer ser importante, muitas vezes não trouxe informações relevantes para esta Tese; o sigilo não é, necessariamente, garantia de informação. Para identificar e explicar as ocorrências ocultas é necessário denso acervo, para encontrar, nas linhas e entrelinhas, no explícito e no insinuado, na afirmação e no silêncio, detalhes que ao serem amalgamados e relacionados a contextos e outras documentações permitam reconstruir e compreender esse passado. Os pesquisadores de conexões entre ditaduras de segurança nacional, sempre vão precisar de um extenso acervo, e diante dele eleger o que faz sentido no seu recorte, para seu tema e objeto, bem como identificar os silêncios e omissões nos acervos que, por si só, tornam-se alertas ao historiador.

De que se trata um arquivo? Dois pontos que auxiliam no esclarecimento: os arquivistas consideram que o arquivo é um conjunto de documentos, que são reunidos por processo de acumulação, no decorrer de atividades de pessoas físicas ou jurídicas, públicas ou privadas. Por outro lado, e para além de um espaço com objetivo de guardar documentos, um 
arquivo comporta uma relação tripla: acervos-espaço-agentes ${ }^{32}$. Nesta pesquisa o acervo foi abordado sob essa perspectiva, em que documentos, pesquisador e espaço dialogaram.

Um acervo documental ${ }^{33}$ denota diversos usos, e muitas vezes seus atos de origem podem se transmutar e reverberar questões que não estavam em seu escopo de raiz. Dessa forma os acervos pesquisados guardam documentos que a priori serviram para perseguir pessoas. Acervos da repressão comportam o que se chama informação "sensível”, pois contêm informações que, em muitos casos, carregam intimidade e situações com as quais os envolvidos diretamente - enquanto vítimas - podem não estar preparados para ter contato, ou mesmo não ter interesse em difundir publicamente.

Portanto, é imprescindível que se tome alguns cuidados, mesmo considerando que "os acervos da repressão são patrimônio de todo um Povo, que devem ser preservados da forma mais íntegra possível. Em seu conjunto e por extensão, é patrimônio de toda a Humanidade enquanto podem fortalecer sua memória." ${ }^{34}$ Esse fortalecimento de memória, todavia, deve levar em consideração que se tratam de pessoas que carregam traumas.

É preciso ressaltar, também, os "ciclos dos documentos"35 e apontar como se encaixam os que constam dos acervos pesquisados: Como documentos correntes, eles serviram ao instante do presente, no aguardo do
despacho necessário. A espera da realização de ações decorrentes da decisão inscrita
nos documentos caracteriza a fase intermediária da vida documental. Sua terceira
fase de vida, a fase permanente, é a memória da ação produzida e consumada. ${ }^{36}$

Dessa forma, para além de representar e reverberar ocorrências do passado, os documentos que compõem acervos de cunho repressivo, que no presente são utilizados para ampliar as políticas de memória, apresentam uma transmutação da realidade social e política.

Um documento que alhures serviu para condenar como "inimigo do Estado" determinado cidadão, hoje é um instrumento de garantia dos direitos desse mesmo cidadão. Ou seja, o mesmo conteúdo e corpo documental apresenta uma razão diversa e contrária da sua primeira função. Seu sentido só mudou porque a sociedade que o comporta também se

32 CATELA, Ludmila da Silva. O mundo dos arquivos. In: REATEGUI, Felix (Org.). Justiça de Transição Manual para a América Latina. Brasília/Nova Iorque: Ministério da Justiça/ICTJ, 2011. p. 379-401.

33 Entende-se como documento todo tipo de substrato que esclareça, evidencie e/ou narre algo, fotografias, filmes, letras musicais, poemas, enfim uma série de vestígios que auxiliam a reconstruir o passado histórico.

${ }^{34}$ QUINTANA, G. A. Archives of the Security Services of Former Repressive Regimes. Janus, n. 2, p. 7-23, 1998.

${ }^{35}$ BELLOTO, Heloísa. Arquivos permanentes: tratamento documental. Rio de Janeiro: FGV, 2007.

${ }^{36}$ KNAUSS, Paulo; OLIVEIRA, Camila Costa. Usos do passado e arquivos da polícia política. In: QUADRAT, Samantha Viz (Org.). Caminhos cruzados: história e memoria dos exílios latino-americanos no século XX. Rio de Janeiro: Editora FGV, 2011. p. 290. 
alterou, suas estruturas e instituições foram substituídas, seu modelo de exceção foi transmutado pelo regime democrático. A preservação destes documentos atesta a alteração social e política do Estado. "O sistema de arquivos é base da superação da opacidade do Estado. Interessa sublinhar que, diante desse duplo caráter, os arquivos são expressão da democracia e afirmam o campo da cultura e da memória como um campo de garantias de direitos" $"$.

São objetivos desta Tese:

- Descrever o caráter e funcionamento da Operação Condor;

- Expor como os Montoneros analisavam a colaboração repressiva na fronteira;

- Apresentar o conceito de fronteira e identificar as relações fronteiriças na região de estudo da Tese;

- Identificar as instituições que atuaram na repressão da fronteira estudada;

- Analisar as ocorrências repressivas na região fronteiriça Uruguaiana - Paso de los Libres.

Para atender a esses objetivos, a Tese está estruturada em três eixos, divididos em dois capítulos cada. O primeiro tem como tema a Operação Condor, e sua finalidade é compreender essa rede de colaboração, que alcança o Rio Grande do Sul. Para tanto, são analisadas as ditaduras militares do Brasil, Argentina e Chile, as conexões repressivas e o terrorismo de Estado (TdE).

O segundo eixo tem como objetivo entender essas conexões no contexto de fronteira. Foi feita uma discussão do conceito de fronteira, e daquela objeto desta Tese, Uruguaiana Paso de los Libres. Esta região é área de contato e afastamento, onde coexistem integrações e diferenças. Como se comporta e o que comporta essa fronteira, no contexto ditatorial? Como esse território é vivenciado e como foram executadas as colaborações repressivas? Essas são as perguntas que serão respondidas neste segundo eixo. Para além disso, é demonstrada a composição da repressão nessa região, e são estudados casos ocorridos ali, que retratam como nela funcionavam as conexões repressivas.

No terceiro eixo encontra-se a repressão oculta, a estruturação desta com a instalação de um centro de detenção clandestino, qual era o grupo em que as vítimas, destas ocorrências ocultas, participavam de que modo este grupo: montoneros tornou-se prioridade da repressão

\footnotetext{
${ }^{37}$ KNAUSS, Paulo; OLIVEIRA, Camila Costa. Usos do passado e arquivos da polícia política. In: QUADRAT, Samantha Viz (Org.). Caminhos cruzados: história e memoria dos exílios latino-americanos no século XX. Rio de Janeiro: Editora FGV, 2011. p. 292.
} 
nos anos do Plano Condor, que contempla o período delimitado nesta Tese. Para então tratar dos mais emblemáticos casos de conexão repressiva ocorridos no local.

Os casos de Lorenzo Ismael Viñas e padre Jorge Adur já foram citados em outros trabalhos: na dissertação de mestrado de Nilson Mariano ${ }^{38}$, que abordou o sequestro de seis argentinos militantes Montoneros ocorridos no Brasil durante o mais recente ciclo de ditaduras, através de estudo de caso o autor revela as atividades da Operação Condor. Os casos que este autor analisou ocorreram no Paraná, Rio de Janeiro e na fronteira do Rio Grande do Sul, são eles: Enrique Ernesto Ruggia, Noberto Habegger, Horácio Domingo Campiglia, Mônica Pinus de Binstock, Padre Jorge Oscar Adur e Lorenzo Ismael Viñas. Esse autor analisa os Montoneros sequestrados no Brasil, enquanto esta Tese busca, a partir dos casos analisados, reconstruir e explicar as articulações repressivas na fronteira.

No livro de José Mitchell ${ }^{39}$, repórter que trabalhou em jornais como Zero Hora, Diário de Notícias e Jornal do Brasil, os casos que são analisados nesta Tese foram abordados de forma genérica, no contexto da repressão e das redes de solidariedade no Rio Grande do Sul. Seu livro é a versão de um repórter sobre a esquerda e a direita durante a última ditadura brasileira, suas percepções agregadas com documentos e entrevistas com agentes importantes no cenário abordado pelo autor. Neste livro além dos casos de Adur e Viñas o autor aborda os casos de Margarita e Cristina, ainda dentro do seu objetivo de desvelar histórias no contexto gaúcho.

A tese de Jorge C. Fernandez ${ }^{40}$, concentra-se na imigração argentina no Brasil. O autor tem como objetivo realizar uma pesquisa qualitativa acerca da presença de argentinos na região sul do Brasil, entre os anos 1966 e 1989. E sua intenção é a de compreender esses fluxos migratórios, abordando-os pela perspectiva histórica. Ele aborda os casos tratados nesta Tese no aspecto migratório e imbricados com diversos outros casos, singulares e plurais.

Esta tese se diferencia desses trabalhos porque, além de utilizar documentação inédita, o corte espacial é o fronteirço e a contextualização vai mais além das dimensões nacionais, de Argentina e Brasil, para também inserir as ocorrências repressivas na dinâmica cotidiana de Uruguaiana e Paso de los Libres.

\footnotetext{
${ }^{38}$ MARIANO, S. Nilson. Montoneros no Brasil - Terrorismo de Estado no seqüestro-desaparecimento de seis guerrilheiros argentinos. Porto Alegre: PUCRS, 2006. Dissertação, Mestrado em História - PUCRS. Porto Alegre, 2006.

${ }^{39}$ MITCHELL, José. Segredos à direita e à esquerda na ditadura militar. Porto Alegre: RBS Publicações, 2007.

${ }^{40}$ FERNANDEZ, Jorge C. Anclaos en Brasil: a presença argentina no Rio Grande do Sul (1966-1989). Porto Alegre: UFRGS, 2011 Tese (Doutorado em História) - Programa de Pós-Graduação em História da UFRGS. Universidade Federal do Rio Grande do Sul, Porto Alegre, 2011.
} 
Mariano escreveu sobre os Montoneros no Brasil e a Operação Condor, já Mitchell analisou a direita e esquerda no Rio Grande do Sul e Fernandez tratou do caso de Viñas, padre Adur, Margarita e Cristina de forma objetiva, abordando os exílios de argentinos no Brasil ${ }^{41}$. Esta Tese, por sua vez, analisa os casos de desaparecimento, para identificar como eles ocorriam em uma região fronteiriça e eram viabilizados ideologicamente, pela utilização de novos conceitos como Segurança Nacional e inimigo interno por parte das ditaduras brasileira e argentina.

Há uma considerável bibliografia sobre a repressão no Cone Sul na década de 1970 e alguns dos livros mais relevantes encontram-se citados nesta Tese. Destaque-se as obras que no decorrer da Tese o leitor encontrará. As obras que abordam o eixo temático da Operação Condor: o livro clássico de John Dinges ${ }^{42}$ uma das mais abrangentes obras sobre o tema; bem como o trabalho de Stella Calloni ${ }^{43}$ que foi pioneira nas publicações sobre a temática e o importante livro de Luiz Cláudio Cunha ${ }^{44}$ que retrata a experiência vivenciada pelo repórter diante de uma ação do Condor no Rio Grande do Sul.

Acerca do segundo eixo temático da tese, sobre especificamente Uruguaiana e Paso de los Libres, a bibliografia é escassa. Existem alguns trabalhos memorialísticos, mas os de cunho historiográfico são raros. Já sobre o conceito de fronteira e a fronteira Sul, foi de grande valia duas obras. O livro de Alejandro Grimson ${ }^{45}$ baseado em sua tese de doutorado, que tratou especificamente sobre a fronteira Uruguaiana e Paso de los Libres; quanto ao conceito de fronteira que foi empregado nesta Tese, teve como inspiração a tese de doutorado de Mariana Flores da Cunha Thompson Flores ${ }^{46}$, que estuda o contrabando de gado na região no século XIX e demonstra o manejo da fronteira, ou seja, como ela pode ser flexível de protagonismo conforme o contexto histórico.

${ }^{41}$ FERNANDEZ, Jorge C. A banalização da Operação Condor: o estranho caso de Cristina Fiori de Vina, novembro de 1979. In: XXVI Simpósio Nacional de História: Anpuh 50 anos, 2011, São Paulo. Anais do XXVI Simpósio Nacional da Anpuh - Associação Nacional de História. São Paulo: ANPUH-SP, 2011.

42 DINGES, John. Os anos do Condor: uma década de terrorismo internacional no Cone Sul. 1 ed. São Paulo: Companhia das Letras, 2005.

43 CALLONI, Stella. Operación Condor: los años del lobo. 1. ed. Buenos Aires: Peña Lillo Ediciones Continente, 1999.

${ }^{44}$ CUNHA, Luiz Cláudio. Operação Condor. O Sequestro dos Uruguaios. Uma reportagem dos tempos da ditadura. Porto Alegre: L\&PM, 2008.

${ }^{45}$ GRIMSON, A. La nación en sus límites - Contrabandistas y exilados en la frontera Argentina-Brasil. Barcelona: Editorial Gedisa S/A, 2003.

46 THOMPSON FLORES, Mariana F. da C. Crimes de fronteira: a criminalidade na fronteira meridional do Brasil (1845-1889). Porto Alegre: PUCRS, 2012. Tese de doutorado em História. Programa de PósGraduação em História PUCRS. 
No campo do Terrorismo de Estado e Doutrina de Segurança Nacional (DSN), as principais obras elencadas e trabalhadas na Tese, destaque-se o emblemático "a ideologia da Segurança Nacional", de Joseph Comblin ${ }^{47}$ que demonstra como o poderio militar apossou-se de uma ideologia para impor o poder e manter-se nele na América Latina. Também foi utilizado "Geopolítica do Brasil", do general Golbery do Couto e Silva, cuja análise repercutiu na fundamentaçãoo teórica da Doutrina de Segurança Nacional no Brasil.

A respeito do conceito de Terrorismo de Estado, foram utilizadas principalmente as obras de Enrique Serra Padrós, um dos mais relevantes pesquisadores sobre esta temática, em especial sua tese de doutoramento ${ }^{48}$ que de forma exaustiva e densa definiu como o Terrorismo de Estado foi implantado no Uruguai. Também foi utilizada a obra de Alejandra Pascual $^{49}$ que fez um dos primeiros trabalhos que definiu o conceito de Terror de Estado na Argentina. Já a dissertação de mestrado de Caroline Silveira Bauer ${ }^{50}$, analisa as práticas do Departamento de Ordem Política e Social do Rio Grande do Sul (DOPS/RS) durante a mais recente ditadura brasileira. Esta autora apresenta fortes indícios de Terrorismo de Estado na montagem do aparato estatal de cunho repressivo.

Esta Tese entende o Terrorismo de Estado não como terror generalizado, ou seja, que alcançava todos os setores sociais, todos os habitantes do país. O TdE apresenta-se com suas violências física - sequestros, torturas e mortes - e as de outro caráter - vigilância de pessoas, a censura a autores, os expurgos nas Universidades, etc., - privilegiando setores políticos e profissionais específicos, de oposição. O Terror de Estado não tem um único modus operandi mas, sim, compreende um conjunto de práticas embasadas teoricamente na Doutrina da Segurança Nacional.

\footnotetext{
${ }^{47}$ COMBLIN, Joseph. A ideologia da segurança nacional: o poder militar na América Latina. Trad. de Veiga Fialho. 3. ed. Rio de Janeiro: Civilização Brasileira, 1980.

${ }^{48}$ PADRÓS, Enrique Serra. Como el Uruguay no hay...Terror de Estado e Segurança Nacional - Uruguai (1968-1985): do Pachecato à Ditadura Civil-Militar. Porto Alegre: UFRGS, 2005. Tese, Doutorado em História - UFRGS. Porto Alegre, 2005.

${ }^{49}$ PASCUAL, Alejandra L. Terrorismo de Estado - A Argentina de 1976 a 1983. Florianópolis: UFSC, 1997. Tese, Doutorado em Direito - UFSC. Florianópolis, 1997.

${ }^{50}$ BAUER, Caroline Silveira. Avenida João Pessoa, 2050 - 3o andar: terrorismo de Estado e ação de polícia política do Departamento de Ordem Política e Social do Rio Grande do Sul (1964-1982). Dissertação de Mestrado Programa de Pós-Graduação em História da Universidade Federal do Rio Grande do Sul. UFRGS, Porto Alegre, 2006.
} 


\section{OPERAÇÃO CONDOR}

El cóndor es una espécie de buitre, que habita en casi toda América del Sur, vuela a gran altura y con sus alas desplegadas puede llegar a medir más de tres metros. Tiene una vista privilegiada y es muy dificil que una presa que se cruza en su horizonte logre escapar de sus fuertes garras. ${ }^{51}$

\subsection{Ditaduras articuladas}

A partir dos anos 1960 a América Latina, de maneira sistemática, foi palco de uma tomada do poder estatal por militares. Foram ocorrências praticamente em cadeia, com características peculiares em cada caso. Essa Tese trata do último ciclo de ditaduras no Cone Sul, em especial nas conexões de repressão estabelecidas nesse contexto. Nos anos 1970 relações foram formalizadas, no Cone Sul, com intuito de ampliar o poder repressivo estatal; essa normatização foi a chamada Operação Condor ou Plano Condor. A centralização e a formalização ocorreram no Chile, sob responsabilidade da Direción de Inteligencia Nacional (DINA).

As disputas internas pelo poder não eram novidade no Cone Sul - as tensões são um contínuo. A Argentina em 1930 e 1943 teve o governo civil derrubado por militares, e em 1946 o "peronismo" "52 venceu as eleições. O presidente Juan Domingo Perón foi deposto em 1955 - nessa ocasião, a articulação foi entre o Exército e a Igreja Católica, com o apoio dos Estados Unidos da América (EUA). Em 1962, uma crise política levou a renúncia de Arturo Frondizi. Essa situação reverberou em uma ruptura interna no Exército argentino: duas facções se enfrentaram, e os "azuis" venceram. Seu representante era Juan Carlos Onganía, que em 1966 assumiu o poder por meio de um golpe militar. Em 1973, o peronismo voltou ao governo da Argentina, e foi derrubado em 1976 pela junta militar.

A monarquia foi derrubada no Brasil em 1889 - o primeiro presidente da República foi Marechal Deodoro da Fonseca, que renunciou em 1891, mesmo ano da primeira Constituição Republicana. Em seu lugar, outro militar assumiu a presidência: Floriano Peixoto. A Revolução de 1930, entre diversas tentativas de revolta contra o governo na República Velha, foi a que conseguiu derrubar o presidente da República Washington Luís e

\footnotetext{
${ }^{51}$ MARTORELL, Francisco. Operación Cóndor: el vuelo de la muerte. Santiago: LOM Ediciones, 1999. p. 36.

52 Juan Domingo Perón foi eleito presidente da Argentina em três ocasiões: 1946, 1951 e 1973, foi um dos fundadores e principal expoente do Movimento Nacional Justicialista, que posteriormente se tornou o Partido Justicialista. A doutrina e filosofia desse movimento se "apropriou" do sobrenome de seu membro mais saliente e ficou conhecida como peronismo. São discutíveis suas plataformas e o quanto tem de populista e autoritário, é emblemático na política Argentina e também latino americana.
} 
impediu a posse do eleito Júlio Prestes. Getúlio Vargas assume a posse do que chamou de "governo provisório".

Getúlio Vargas optou pela via autoritária: instaurou o Estado Novo em 1937 e suprimiu o parlamento. Em 1945, após o fim do Estado Novo, o Brasil se "democratizou" novamente, e o Partido Comunista do Brasil foi legalizado. Porém, em 1964, os militares assumiram o poder no Brasil, e deram início aos 21 anos de regime ditatorial.

Em 1973, o parlamento do Uruguai foi dissolvido através de um golpe militar. O país já havia enfrentado outro período de supressão democrática em 1934, quando o presidente Gabriel Terra, que governava por decreto desde 1933, promulgou uma nova constituição transferindo todos os poderes ao presidente.

O Chile teve sua democracia derrubada por Augusto Pinochet com apoio e financiamento dos EUA em 1973. Foi iniciado um processo com objetivo de eliminar os partidos de esquerda, movimentos sociais e sindicatos. O golpe de Pinochet pôs fim a uma longa história política do Chile, o qual já na década de 1840 consolidara o Estado Nacional, construindo uma estabilidade política e tradição parlamentar e, no século XX, de 1925 a 1973 vivenciou uma democracia liberal. ${ }^{53}$

Em 1947, no Paraguai, uma guerra civil começou, e culminou com a vitória do Partido Colorado. Em 1954, Alfredo Stroessner se apossou do poder e instaurou paulatinamente uma ditadura. O Paraguai enfrentou uma sequência de golpes de Estado iniciados em 1904, com diversos presidentes interinos, até a tomada de poder por Stroessner, que permaneceu até 1989 na presidência.

A Bolívia, em 1952, após a vitória do Movimento Nacionalista Revolucionário (MNR), sofreu uma ameaça de anulação dessas eleições pelos militares, que foram contidos por meio de uma insurreição popular; porém, em 1964 o governo do MNR foi derrubado. Em 1969, o general Alfredo Ovando Candia toma o poder de seu colega René Barrientos, e um governo nacionalista tem início, até que Hugo Bánzer Suárez comanda um golpe militar e toma o poder, dissolve a Assembleia Popular, e começa a perseguição de seus opositores. ${ }^{54}$

Essa exposição breve tem o intuito de pontuar que a ocupação do poder pelos militares não foi um processo imediato e único, pois todos esses países vivenciaram situações complexas no campo político, terminando com a intervenção militar. A influência militar no

\footnotetext{
${ }^{53}$ VILLALOBOS, Sergio R. Breve historia de Chile. Santiago do Chile: Editorial Universitaria, S.A., 1983. P. 25.

${ }^{54}$ COMBLIN, Joseph. A ideologia da segurança nacional: o poder militar na América Latina. Trad. de Veiga Fialho. 3. ed. Rio de Janeiro: Civilização Brasileira, 1980. p. 19-20.
} 
campo político não foi uma situação exclusiva das ditaduras mais recentes no Cone $\mathrm{Sul}^{55}$. As particularidades desses regimes vigentes nos anos 1970 serão tratadas nesse capítulo: suas conexões, interesses e atuações, especialmente os casos da Argentina e do Brasil, e suas implicações na Operação Condor.

\subsubsection{Ditaduras no Cone Sul nos anos 1970}

No final dos anos 1970 a população latino-americana era estimada em 400 milhões de pessoas; dessas, dois terços, ou seja, em torno de 270 milhões de pessoas, estavam vivendo em Estados sob regimes ditatoriais, impostos por militares e/ou geridos por representantes castrenses. ${ }^{56}$ Esses dados são extremamente representativos. Como isso se configurou é o que será tratado nesse capítulo. As sociedades vivenciaram o Estado sendo tomado por modelos antidemocráticos de governo, e que, em geral, implantaram o terrorismo de Estado (TdE) como forma de coerção, com intuito de permanecer no poder.

As ditaduras mais recentes na América Latina, no seu nascimento, estão intimamente ligadas com o poderio dos Estados Unidos. A influência norte-americana na implantação destes sistemas de governo na América Latina foi viabilizada em todos os campos, mas principalmente no aspecto econômico e político. Devemos ressaltar que o período que antecedeu as implantações das últimas ditaduras latino-americanas coincide também com a Guerra Fria e com a tomada do poder em Cuba, por Fidel Castro, em 1959. Os Estados Unidos assistiriam impassíveis a uma mudança política significativa nos países latino americanos, na área de sua influência direta? Várias medidas foram tomadas para conter um possível avanço do comunismo na América Latina: um exemplo é a Aliança para o Progresso, plano que previa ajuda dos Estados Unidos para o desenvolvimento econômico de outros países, e que contribui para uma aproximação mais estreita dos Estados Unidos da América. ${ }^{57}$

\footnotetext{
${ }^{55}$ Sobre essa efervescência de supressão da democracia, em cadeia, na América Latina, Calloni pontua muito bem, em síntese esse aspecto. Cf. CALLONI, Stella. Operación Condor: los años del lobo. 1. ed. Buenos Aires: Peña Lillo Ediciones Continente, 1999. p. 15-16.

56 BORGES, Nilson. A Doutrina de Segurança Nacional e os governos militares. In: FERREIRA, Jorge; DELGADO, Lucília de A. N. O tempo da ditadura: regime militar e movimentos sociais em fins do século XX. Rio de Janeiro: Civilização Brasileira, 2009. p. 25. (O Brasil Republicano; v. 4).

${ }^{57}$ GUAZZELli, Cesar Augusto Barcellos. História Contemporânea da América Latina: 1960-1990. 2. ed. Porto Alegre: Editora da UFRGS, 2004. p. 15; WASSERMAN, Claudia; GUAZZELLI, Carlos Augusto Barcellos; MIX, Miguel Rojas... [et al]. Porto Alegre: Editora da UFRGS, 2004. p. 29.
} 
Portanto a região tinha de ser cooptada com intuito de não se espelhar no exemplo cubano e promover uma grande revolução latina, que pudesse desestabilizar o poderio norteamericano e o seu sistema capitalista, pauta deste contexto histórico, que não significa uma interferência durante todo o período ditatorial implantado em cada país da América Latina.

O panorama da América Latina na década de 1960 era diverso: países que se encontravam em um sistema ainda oligárquico pré-capitalista, inalterado por mais de um século; ou então, países onde a separação da oligarquia e do Estado tinha se consolidado com sucesso, que receberam assistência para o desenvolvimento industrial, culminando na ampliação do mercado interno e atendendo aos interesses de grupos médios e populares. Os países latinos encontravam-se divididos economicamente (divisão interna), onde as políticas ditas populistas de seus governantes não atendiam plenamente às burguesias e também não conseguiam atender aos anseios das camadas sociais menos favorecidas.

Com a implantação e difusão de práticas capitalistas, temos um distanciamento ainda mais saliente entre as burguesias e os setores médios e populares. Este distanciamento não era favorável aos objetivos econômicos do sistema capitalista, pois rupturas poderiam levar a revoltas. Portanto, uma das justificativas, utilizadas pelos responsáveis pelos golpes em cada país, para retroceder com a democracia era conter revoltas populares. Conforme Guazzelli, “os governos latino-americanos paulatinamente tornaram-se ditatoriais, militarizados, capacitando-se com o apoio dos Estados Unidos, para o enfrentamento da ameaça que pairava" ${ }^{, 58}$. Ressaltando, que este apoio ocorreu na implementaçãoo dos regimes ditatoriais, mas, posteriormente, no governo de Jimmy Carter (1977-1981) foi implementada uma política de defesa dos Direitos Humanos que colocou-o em atrito com regimes autoritários que, afinal, seus antecessores tinham colocado no poder.

De que maneira os Estados Unidos far-se-iam presentes no Brasil? Aproveitando-se da fragilidade da aliança burguesia-populismo - e do receio destas burguesias diante das antigas oligarquias, bem como das camadas populares, no sentido de que encontrassem e articulassem alguma hegemonia ideológica - os norte-americanos sugeriam uma aliança com as forças armadas, e essas se alinhariam com a elite. Assim, estes grupos mais favorecidos economicamente, representantes do poderio econômico, estariam assegurando-se de desestabilizar, no primeiro momento, o regime dito populista de João Goulart, e também dos supostos comunistas instalados na sociedade. ${ }^{59}$

\footnotetext{
${ }^{58}$ GUAZZELli, Cesar Augusto Barcellos. História Contemporânea da América Latina: 1960-1990. 2. ed. Porto Alegre: Editora da UFRGS, 2004. p. 24.

${ }^{59}$ Para uma análise dessas alianças, cf. DREIFUSS, René Armand. 1964: a conquista do Estado. Petrópolis, RJ:
} 
Ressalte-se que havia um processo de industrialização já se desenhando com os governos ditos populistas, mas que ganhou força e apoio quando esses governos encontraram financiamento na América do Norte. Em troca desse impulso econômico, os favorecidos colaboram com a intervenção militar, ficando assim divididas as tarefas e responsabilidades. O desenvolvimento econômico ocorreria de maneira paulatina, e dessa forma eficaz, já que contava com o apoio e segurança do Exército, que controlava todas as atitudes desfavoráveis ao modelo de gestão que implantariam. Parece que a "revolução" - como os militares brasileiros se referem ao golpe de Estado de 1964 - e o "processo" na Argentina em 1976, citando apenas dois exemplos na América Latina, foram acordos de cavalheiros entre classes dominantes, com apoio no princípio do imperialismo norte-americano. ${ }^{60}$

Uma vez instaurado o sistema de governo ditatorial militar, há mais alguns aspectos gerais no caso latino-americano para analisar antes de verificar as ditaduras do Brasil e Argentina e suas articulações. Parcelas da sociedade aceitaram as intervenções militares, pois era um "mal menor" diante da ameaça das revoltas populares e da situação econômica, caótica em alguns $\operatorname{casos}^{61}$, mas que, mesmo assim, não justificava a intervenção militar implantada. Assim, o cenário da América Latina é montado sob um esquema no qual a economia agroexportadora podia desenvolver-se e atender à demanda mundial por seus produtos amparada por uma política onde os detentores da matéria-prima eram o rosto da nação, garantidos no poder econômico pela força militar que os escoltava, deixando nos bastidores e alijando todos os demais setores sociais.

Esses setores que foram alijados do novo modo de governo, principalmente no sentido político, configuravam o segundo motivo do apoio e empenho norte-americano para a implantação das ditaduras latinas. Além de obter vantagens econômicas com essa intervenção, politicamente estariam freando as manifestações comunistas ou socialistas que pudessem florescer no seio dos respectivos países. Desse modo, os setores que foram mais impactados

Vozes, 1986; MORAES, Thiago Aguiar de. "Entreguemos a emprêsa ao povo antes que o comunista a entregue ao Estado": os discursos da fração "vanguardista" da classe empresarial gaúcha na revista "Democracia e Emprêsa" do Instituto de Pesquisas Econômicas e Sociais do Rio Grande do Sul (1962-1971). 2012. 227 p. Dissertação (Programa de Pós-Graduação em História) - Pontifícia Universidade Católica do Rio Grande do Sul, Porto Alegre; STARLING, Heloísa Maria Gurgel. Os senhores das gerais: os novos inconfidentes e o golpe de 1964. Petrópolis, RJ: Vozes, 1986.

${ }^{60}$ GUAZZELLI, Cesar Augusto Barcellos. História Contemporânea da América Latina: 1960-1990. 2. ed. Porto Alegre: Editora da UFRGS, 2004. p. 28.

${ }^{61}$ Vezzetti, em dois livros: VEZZETTI (a), 2009; e VEZZETTI, Hugo (b). Sobre la violencia revolucionaria: memorias y olvidos. Buenos Aires: Siglo Veintiuno Editores, 2009, trata desse tema, ainda, pouco debatido na academia e fora dela, a participação - ativa ou passiva- de parcelas da sociedade civil. Nesse parágrafo, se refere aos passivos, ou seja, que não questionaram a intervenção militar, ou poderiam acreditar que, de fato, era necessária tal medida. Muitas bibliografias mais arejadas sobre o tema, já contemplam essa discussão, como as de Vezzetti que no decorrer dessas duas obras esclarece, que sim, uma parcela significativa das sociedades latinas apoiavam essas intervenções - principalmente na fase inicial. 
com o isolamento e a repressão foi o de militantes de esquerda, sindicatos e organizações populares.

O antagonismo ideológico mundial entre capitalismo e socialismo criava um ambiente conflituoso, onde o vencedor seria a nova hegemonia político-econômica, e serviria de paradigma para todos os países em desenvolvimento. Evitar que outros países no continente americano aderissem ao socialismo foi a meta desta ocasião e, para tanto, não foram poupados esforços de nenhuma ordem:

\begin{abstract}
Em poucos anos, o panorama político da América Latina mudou: as oligarquias mais conservadoras, que tinham vivido breves momentos de aprêmio, eram consolidadas; os regimes populistas desabavam um após o outro como castelo de cartas. Ditaduras militares implantavam-se por todo o subcontinente e desenvolviam sofisticados métodos de repressão interna para sufocar toda e qualquer forma de oposição. Como fiadores desta realidade, os Estados Unidos, envolvidos em conflitos por todos os continentes, tratavam de garantir ferreamente a dominação sobre o seu quintal. ${ }^{62}$
\end{abstract}

Iniciava-se na América Latina, com o golpe civil-militar de 1964 uma temporada ditatorial, onde o Estado detinha o poder e controle, e as parcelas que estavam contrárias aos regimes impostos, foram submetidas a repressão, agressão e violação de seus direitos, não só os constitucionais de cada país, mas dos direitos humanos como um todo, principalmente quando, estes governos ditatoriais, passaram a atuar em conjunto na agenda repressiva. A década de 1970, para os latino-americanos, foi um período onde imperou o desrespeito, a injustiça, a violência e a impunidade:

Direitos do homem, democracia e paz são três momentos necessários do mesmo movimento histórico: sem direitos do homem reconhecidos e protegidos, não há democracia; sem democracia, não existem a condições mínimas para a solução pacífica dos conflitos. ${ }^{63}$

Conforme destacado, diante de um regime ditatorial, que regrava o cotidiano social e político, os cidadãos latinos estiveram com seus direitos negados. Em perspectiva advogada por Bobbio, na obra aludida, e da qual compartilho, os direitos do homem são históricos. Ou seja, são fruto de pactos, de lutas e disputas, entre os poderes estabelecidos e as necessidades de conjuntura social. Nesse sentido, entende-se que os direitos se ampliam, visto que é um processo que não está encerrado, assistem-se avanços e retrocessos no decorrer do movimento histórico. Essa ampliação, que Bobbio chama de evolução paulatina de direitos, acarreta em

\footnotetext{
${ }^{62}$ GUAZZELLI, Cesar Augusto Barcellos. História Contemporânea da América Latina: 1960-1990. 2. ed. Porto Alegre: Editora da UFRGS, 2004. p. 27-28.

${ }^{63}$ BOBBIO, Norberto. A era dos direitos. Rio de Janeiro: Elsevier, 2004. p. 1.
} 
um número maior de diversidade social sendo contemplada no pacto da sociedade com o Estado - conquistas que são históricas e graduais. Quando o Estado sofre uma intervenção que suspende os direitos já adquiridos, temos não só uma ruptura no conjunto de direitos do homem, mas um retrocesso nesse processo de conquista.

Os Estados ditatoriais no Cone Sul implantados no último ciclo de supressão democrática, mais do que suprimir os direitos do homem, implantaram um sistema de repressão e terror sem precedentes na região citada: o Terrorismo de Estado. É esse processo que diferencia as mais recentes ditaduras do Cone Sul das suas experiências anteriores. O Estado que deveria suprir a segurança é o mesmo que impõe o terror, e esse mecanismo transcende fronteiras quando os agentes de repressão atuam em vários países e os cidadãos são, literalmente, caçados em diversos Estados.

\subsubsection{Terrorismo de Estado e segurança nacional no Cone Sul}

Sem dúvida, as experiências de supressão da democracia nos anos 1970 no Cone Sul se distinguem das ocorridas alhures nos países desta região por dois processos, até então inéditos: o Terrorismo de Estado e a Doutrina de Segurança Nacional. A preocupação nas mais recentes experiências ditatoriais esteve centrada dentro de suas fronteiras, com os "inimigos internos", ou seja, aqueles que se colocavam contra o modelo ditatorial implantado.

Nessa toada, tivemos o que o historiador Rodrigo Patto Sá Motta chama de "indústria do anticomunismo", ou seja, um amálgama entre ações e representações contra o "perigo vermelho"; foram explorados de forma vantajosa medos já existentes ao comunismo, ao mesmo tempo em que se difundia e ampliava supostas ameaças que um sistema político comunista acarretaria na sociedade. A "indústria do anticomunismo" assumiu diversas características ao longo do tempo e foi explorada por diversos agentes sociais: o Estado, imprensa, líderes políticos e religiosos, agentes da repressão. O Estado, com ajuda de outros setores, dessa forma, produziu um "inimigo interno", um perigo que deveria ser contido. ${ }^{64}$

Com essa justificativa, a experiência das ditaduras do Cone Sul contemplou uma caçada, literalmente, aos ditos "subversivos". A característica comum desses regimes ditatoriais era conter o comunismo e evitar efeitos ideológicos da Revolução Cubana, conforme versa Coggiola: "a tensão internacional - Estados Unidos versus URSS, ou 'comunismo versus mundo livre' - forneceria justamente o álibi ideológico para os golpes

\footnotetext{
${ }^{64}$ MOTTA, Rodrigo Patto Sá. Em guarda contra o perigo vermelho: o anticomunismo no Brasil (1917-1964).
} São Paulo: Perspectiva, 2002. p. 137. 
militares, que afirmaram com unanimidade ser a democracia 'incapaz de conter o comunismo'“. ${ }^{65}$ É nesse quadro que se implanta a Doutrina de Segurança Nacional - que, além de conter a "ameaça comunista", acabava com o regime democrático.

Como se deu a contenção do comunismo? Qual o sistema utilizado para evitar revoluções populares, ao mesmo tempo em que interrompia o exercício democrático? Cada país, embora com algumas preocupações em comum, utilizou um método para que os militares chegassem e se consolidassem no poder, usando como alicerce a almejada segurança nacional. Sabe-se que um governo ditatorial tem especificidades conforme o contexto, mas, ainda assim, conserva parâmetros gerais, como a dissolução das instituições representativas, a militarização da vida social e política e, nesse período, uma ascendência financeira da instituição militar, bem como de seus apoiadores em cada país.

A Doutrina de Segurança Nacional é advinda dos Estados Unidos. Essa ideologia, quando praticada, coloca as massas populares distanciadas da condução do Estado e alijadas de participação em qualquer esfera pública. A Doutrina de Segurança Nacional difundida e estruturada, a priori, pelos Estados Unidos, foi aprimorada - no sentido de localizar, ou seja, atender às especificidades regionais - pelos países do Cone Sul, por meio das escolas militares. Conforme Comblin, ao comparar os conceitos destas doutrinas em diferentes países, percebe-se que a rigidez ideológica advém dos EUA e foi amplamente utilizada na América Latina. ${ }^{66}$ No que se refere à adaptação ou adequação desta doutrina, Ianni aponta:

Segundo esta doutrina, a segurança nacional não depende somente das relações de interdependência (militar, política, econômica e cultural) das várias nações, inclusive e principalmente dos Estados Unidos. Agora, a segurança de cada país depende do inter-relacionamento das forças armadas nacionais com as elites políticas, empresariais, universitárias e religiosas. Assim, cada cidadão, em suas funções profissionais ou fora delas, é responsável pela segurança nacional. ${ }^{67}$

A Doutrina de Segurança Nacional teve como pressuposto a geopolítica, ou seja, a questão territorial no âmbito político - dessa forma, se ancorava no conceito de nação. Um fórmula robusta, já que compreende a nação como um todo, representando os interesses coletivos, ou seja, o interesse nacional, do Estado e, logo, dos cidadãos em geral. Quando a nação está coesa, os conflitos internos tendem a desaparecer, visto que neste sistema o Estado

\footnotetext{
${ }^{65}$ COGGIOLA, Oswaldo. Governos militares na América Latina. São Paulo: Contexto, 2001. p. 11.

${ }^{66}$ COMBLIN, Joseph. A ideologia da segurança nacional: o poder militar na América Latina. Trad. de Veiga Fialho. 3. ed. Rio de Janeiro: Civilização Brasileira, 1980. p. 27-28.

${ }^{67}$ IANNI, Octavio. Imperialismo e cultura. Rio de Janeiro: Vozes, 1976. p. 103.
} 
deveria atender a segurança do território e dos cidadãos. E todos deveriam estar de acordo, já que o objetivo é defender o Estado.

Um modelo eficiente para as circunstâncias do momento, o mundo dividido em dois modelos: capitalismo versus comunismo. Neste quadro, o Brasil detinha uma importância ímpar na questão da segurança na América Latina. É, também, nessa moldura que se insere o inimigo interno, ou seja, aquele que se posicionava contra seu Estado e contra o modelo capitalista ocidental, representando um perigo para toda a nação. Parece simples, mas é extremamente complexo e denso, e na aplicabilidade muito efetivo: os governos ditatoriais na América Latina contaram com apoio além da caserna, para manter a segurança da nação. $\mathrm{O}$ que poderia ser considerado inimigo? Os comunistas? Quem eram os "subversivos"? Conforme as listas de vítimas dos regimes ditatoriais, estes ideologicamente pautados na Doutrina de Segurança Nacional, temos uma pluralidade de indivíduos identificados como inimigos do Estado. Nesse ponto Padrós esclarece:

\begin{abstract}
Em realidade, o perigo é identificado nas "ideologias estranhas", forâneas, externas, diferentes das locais. Pelo desdobramento dos fatos históricos, constata-se que aqueles cidadãos que acabaram identificados internamente com essas "ideologias estranhas" foram tratados como inimigos perigosos dos interesses da unidade nacional, uma vez que não compartilhavam nem defendiam a tradição política (da elite) local. ${ }^{68}$
\end{abstract}

Compreende-se, assim, o inimigo como aqueles que questionam essa pretendida unidade nacional, a saber, comunistas, liberais, democratas, liberais democratas cristãos, entre outros engajados em uma agenda não conservadora e, principalmente, defensores da democracia. A atuação se dá em diversas frentes: difusão nas escolas (por meio de disciplinas doutrinárias), vinculação de propaganda política a favor dos regimes ditatoriais como defensores da nação, e a contrarrevolução ou contra-insurgência.

Identificar e traçar um perfil dos ditos "subversivos" contempla analisar uma pluralidade de indivíduos, que torna muito flexível a sua definição e caracterização. As vítimas do Terrorismo de Estado eram de diversos segmentos sociais, profissões e posições políticas. Segundo Calveiro, os militares tinham incutida a imagem de pessoas perigosas, e a ideia do "mal social" que causavam. Podia ser um guerrilheiro, um simpatizante ou familiar de guerrilheiro. ${ }^{69}$

\footnotetext{
${ }^{68}$ PADRÓS, Enrique Serra. Repressão e violência: segurança nacional e terror de Estado nas ditaduras latinoamericanas. In: FICO... [et al.] Ditadura e democracia na América Latina: balanço histórico e perspectivas. Rio de Janeiro: Editora FGV, 2008. p. 144.

${ }^{69}$ CALVEIRO, Pilar. Poder y desaparición: los campos de concentración en Argentina. 1. ed. 6. reimp. Buenos Aires: Colihue, 2008. p. 35-36.
} 
$\mathrm{Na}$ Argentina circularam manuais com definições criteriosas sobre subversão, subversivos, e como tratar com esses indivíduos. Entre esses o "RE-9-51 Instrucción de lucha contra elementos subversivos" de 1976 e "RC-9-1 Operaciones contra elementos subversivos (proyecto)" de 1975. Foram distribuídos entre unidades militares da Argentina. Estes manuais podem ajudar a refletir sobre o que foi considerado um "subversivo" sob a ótica dos militares argentinos na década de 1970. O primeiro manual define o que é "subversão":

Se entenderá por tal, a la acción clandestina o abierta insidiosa o violenta que busca la alteración o la destrucción de los criterios morales y de la forma de vida de un pueblo, con la finalidad de tomar el poder e imponer desde él, una nueva forma basada en una escala de valores diferente. ${ }^{70}$

Em seguida define a contrasubversión, conjunto de medidas conduzidas por instituições e organismos estatais, forças armadas, de segurança e policiais que tivessem objetivo de eliminar causas e situações subversivas, poderia também: "neutralizar o aniquilar el aparato político-militar del enemigo", ${ }^{\text {, }}$.

Já o segundo manual, "RC-9-1 Operaciones contra elementos subversivos (proyecto)", compreende sete capítulos. Esta obra é mais abrangente que a anterior, além de conceitos sobre subversão, ação subversiva, e táticas militares de "contra subversão", contempla um guia de como deveriam agir na contra-subversão: locais, maneiras e com que tipo de apoio poderiam contar. ${ }^{72}$

$\mathrm{Na}$ terceira parte desta mesma obra, foram determinadas as características dos "subversivos", entre essas: regime de vida e disciplina. O manual justifica a importância dessa classificação:

[...] poseer un profundo conocimiento de la mística, de la formación y de la instruicción de los elementos subversivos, facilitará la preparación de la propria Fuerza y el perfeccionamiento de técnicas que permitan combatirlo con mayor eficacia. ${ }^{73}$

\footnotetext{
${ }^{70}$ Ejército Argentino. RE-9-51: Instrucción de lucha contra elementos subversivos". Buenos Aires, Ejército Argentino. 1976. p. 1.

${ }^{71}$ Ibid. p. 1.

${ }^{72}$ Ejército Argentino. RC-9-1: Operaciones contra elementos subversivos (Proyecto). Buenos Aires, Ejército Argentino 1975. Reservado Ejemplar número 157. p. 1.

${ }^{73}$ Ibidem, p. 29.
} 
Dentre as características das pessoas classificadas como subversivas as mais acentuadas eram o fanatismo, a resistência física e a disciplina. ${ }^{74}$ Detalhadamente:

\begin{abstract}
a) aspectos generales: 1) ser en lo possible de la zona. 2) conocer el medio ambiente 3)tener como idade óptima entre 20 y 30 años, sendo aceptable de 16 a 40 años. 3) ser de temperamento callado y discreto.

b)aspectos de carácter: 1)ser luchador implacable, no aceptando debilidades proprias ni de compañeros. 2) violento, capaz de asesinar a sangre fria. 3) ser desconfiado, para evitar sorpresas. 4) con afan de perfeccionamiento constante.

c) aspecto fisico: tener contextura fisica acorde a las exigencias del tipo de acciones que realizará:resistência a la fatiga, al hambre y a la sed, y ser adaptable a la medio ambiente.

d)aspectos intelectuales: 1) ser inteligente e intuitivo. 2) tener agilidad mental para resolver rápidamente situaciones imprevistas. 3) ser observador y tener buena memoria. 4) tener sagacidad y astucia.

e) aspectos síquicos: 1) tener agresividad. 2) estar preparado para afrontar situaciones de incertitumbre y angustias. 3) tener capacidad para conducirse solo por largos periodos. 4) resistencia a los interrogatorios y a la acción sicológica a que pueda ser sometido. 5) tener espírito de sacrificio. 6) ser capaz de arriesgar su vida, pero no innecesariamente. 6) aceptar el uso de drogas como efervorizante. 8) conocer y participar de la ideologia en la que se apoya la subversión. ${ }^{75}$
\end{abstract}

No manual que trata das operações ainda consta que essas pessoas mantinham uma vida discreta, sem chamar a atenção, com intuito de ocultar suas atividades em grupos de viés "subversivo". 76 Apesar de todo detalhadamento existente nesses manuais, na prática o conceito de subversivo continuava muito flexível e subjetivo, permitindo que uma gama considerável de pessoas pudesse ser caracterizada dessa forma.

É nessa guerra contra os inimigos da nação que se implanta o Terrorismo de Estado. A contenção de pessoas e/ou grupos contrários ao sistema vigente foi executada com base na força e violência - no caso, violência promovida pelo aparato estatal. Nesse ponto, o jogo de poder assume um papel decisivo na aplicabilidade da Doutrina de Segurança Nacional, pois o Estado, responsável pela gestão de segurança, se torna o violador dos direitos dos cidadãos. Bobbio defende que, sem democracia - que pressupõe direitos reconhecidos e protegidos -, “não existem as condições mínimas para a solução pacífica dos conflitos que surgem entre os indivíduos, entre grupos e entre as grandes coletividades"

Dessa forma, a questão da solução de conflitos é o que justifica tanto a democracia como a Doutrina de Segurança Nacional. A grande diferença é que na democracia os conflitos tendem a ser resolvidos por meio do parlamento e manifestações da sociedade civil, enquanto

\footnotetext{
${ }^{74}$ Ejército Argentino. RC-9-1: Operaciones contra elementos subversivos (Proyecto). Buenos Aires, Ejército Argentino 1975. Reservado Ejemplar número 157. p. 30.

${ }^{75}$ Ibidem, p. 30-31.

${ }^{76}$ Idem, p. 32.

${ }^{77}$ BOBBIO, Norberto. A era dos direitos. Rio de Janeiro: Elsevier, 2004. p. 203.
} 
em um regime ditatorial baseado na DSN as tensões internas são contidas de maneira violenta - e violência não apenas física. Conforme Padrós:

\begin{abstract}
A essência de análise sobre o TDE não está na comprovação da discriminação da tortura ou da censura, por exemplo, e sim na compreensão da abrangência, da multiplicidade e da complementação das iniciativas repressivas que, sob hipótese alguma, podem ser reduzidas à violência física, e que compõem esse quadro opressivo, "cinzento", resultado da dinâmica de aplicação do terror de Estado. Terror de Estado que, mesmo respeitando as especificidades, se mostrou abrangente, prolongado, indiscriminado, retroativo, preventivo e extraterritorial. $^{78}$
\end{abstract}

As experiências de violência nas ditaduras mais recentes no Cone Sul apontam para uma forma de coerção diferenciada, com intuito de desmobilizar os inimigos do Estado. Conforme Pascual, quando debateu o Terrorismo de Estado na Argentina, este estava baseado na repressão clandestina, terror e negação de responsabilidades - nas palavras da autora, "criar uma máscara de paz por quanto tinha sido concebido um método repressivo clandestino, à margem da lei" ${ }^{\prime 79}$. Essa modalidade de repressão não divulgada foi efetiva, pois o número elevado de desaparecidos fez com que grande parcela da população ficasse ciente das atividades violentas estatais de forma sutil - ainda que tais atividades não fossem divulgadas, o elevado número de cidadãos desaparecidos informava a existência de uma política violenta e oculta, espalhando de forma velada o terror estatal.

É importante ressaltar que os desaparecidos são emblemáticos para compreender as mais recentes ditaduras na América Latina - principalmente na Argentina, e nas atividades da Operação Condor -, e a lógica do Terrorismo de Estado. A negação das atividades repressivas e a responsabilidade nos desaparecimentos não servem apenas para esfumar e diluir a culpabilidade na violação dos direitos humanos - é de muita utilidade para aterrorizar, e, dessa forma, conter manifestações contrárias ao governo ditatorial. Conforme Calveiro, durante o Processo de Reorganização Nacional, foi utilizado um direito arbitrário como forma de disseminar o terror na sociedade, com intuito de disciplinar, regular e controlar esses cidadãos em conflito:

La exhibición de un poder arbitrario y total en la administración de la vida y la muerte pero, al mismo tiempo, negado y subterráneo emitía un mensaje: toda la población estaba expuesta a un derecho de muerte por parte del Estado. Un derecho que se ejercía con una única racionalidad: la omnipotencia de un poder que queria

\footnotetext{
${ }^{78}$ PADRÓS, Enrique Serra. Repressão e violência: segurança nacional e terror de Estado nas ditaduras latinoamericanas. In: FICO... [et al.] Ditadura e democracia na América Latina: balanço histórico e perspectivas. Rio de Janeiro: Editora FGV, 2008. p. 154.

${ }^{79}$ PASCUAL, Alejandra L. Terrorismo de Estado - A Argentina de 1976 a 1983. Florianópolis: UFSC, 1997. Tese, Doutorado em Direito - UFSC. Florianópolis, 1997. p. 60-61.
} 
parecerse a Dios. Vidas de hombres y mujeres, destinos de niños e incluso de seres que aún no habian nacido, nada podria escapar a él. ${ }^{80}$

Foi com essa perspectiva que as ditaduras dos anos 1970 agiram na América Latina, e articularam seus serviços de repressão com base na tríade do terror - ou seja, sequestrando, torturando e desaparecendo com os inimigos - implantaram um terror estatal, experiência ímpar nos governos não democráticos já vivenciados pelos países latinos. A questão do Terrorismo de Estado, merece uma reflexão que vai além sobre a generalização do medo. No Brasil, parcelas significativas da sociedade não sentiam um ambiente de terror, bem como não viviam essa experiência por não se posicionarem em oposição ao regime. Este concentrou sua capacidade repressiva contra a oposição, particularmente aquela armada ${ }^{81}$.

Pascual, ao analisar o Terrorismo de Estado na Argentina apresenta uma tese que pode ser aplicada aos demais países que vivenciaram regimes ditatoriais baseados na Doutrina de Segurança Nacional, esta autora avalia que uma das estratégias foi a de desmobilizar quem estivesse contra o regime. Afirma que entre as principais preocupações dos militares argentinos estava a de evitar que os grupos armados de oposição angariassem apoio popular e conseguissem, assim, organizar a luta por direitos sociais e políticos que haviam sido perdidos, questionando o modelo socioeconômico imposto pelo regime ditatorial. ${ }^{82}$

Portanto, o terror estatal aplicado no Brasil, Argentina, Chile, Uruguai, Paraguai e Bolívia, por meio do Plano Condor, consistiu em ações e estratégias para conter o avanço das oposições. O terror implantado pelos instrumentos estatais deixaram sequelas nas histórias recentes desses países. Assim, no caso do Brasil, encontram-se no período do regime militar as raízes da violência policial e o modus operandi de fazer interrogatórios violentos, enquanto no plano educacional o ensino de Educação Moral e Cívica persistiu alguns anos do período democrático.

\footnotetext{
${ }^{80}$ CALVEIRO, Pilar. Poder y desaparición: los campos de concentración en Argentina. 1. ed. 6. reimp. Buenos Aires: Colihue, 2008. p. 59.

81 VICENTE, Maria de Fátima. Violência de Estado e resistência (s). In.: OCARIZ, Maria Cristina (Org.). Violência de Estado na ditadura civil-militar brasileira (1964-1985): efeitos psíquicos e testemunhos clínicos. São Paulo: Escuta, 2015. p. 218-219.

${ }^{82}$ PASCUAL, Alejandra L. Terrorismo de Estado - A Argentina de 1976 a 1983. Florianópolis: UFSC, 1997. Tese, Doutorado em Direito - UFSC. Florianópolis, 1997. p. 178.
} 


\subsection{Brasil, Argentina e Chile: as ditaduras de segurança nacional}

Esta seção trata das conexões repressivas institucionalizadas por meio da Operação Condor, e para tanto analisa as experiências ditatoriais brasileira e argentina, para atender à contextualização do estudo de caso Uruguaiana-Paso de los Libres. Analisa ainda a ditadura chilena, pois a formalização da verdadeira internacional do terror ocorreu em território chileno, bem como a sua gestão logística ficou centrada no Chile. Sabemos que os demais países (Uruguai, Paraguai e Bolívia), são importantes signatários ${ }^{83}$ nessa empreitada estatal de contenção de "subversivos" em nível internacional, mas, para as circunstâncias desta Tese, uma análise mais pontual será conduzida para os três países citados, sendo explanadas experiências destes outros países quando necessário, para melhor entendimento do tema e objeto desta Tese.

\subsubsection{O Brasil e seus 21 anos de ditadura}

O último período ditatorial brasileiro foi implantado em 1964, imposto pelos militares com apoio de grandes empresários, setores da Igreja Católica, grandes parcelas da classe média e amplo respaldo midiático. Contou, também, com apoio - inclusive bélico - dos EUA. A participação brasileira na II Guerra Mundial reverberou em uma aproximação e simpatia entre os militares brasileiros e os Estados Unidos, que se tornou o principal fornecedor de armas para o Brasil. A questão cubana, que após a tomada do poder por Fidel Castro se declarou oficialmente comunista em 1961, segundo Fico, fez com que uma nova política para a América Latina fosse desenvolvida pelos Estados Unidos:

[...] baseada no fortalecimento dos militares da região, vistos como bastiões contra quaisquer sonhos revolucionários, e na política de ajuda econômica, sobretudo como pretexto para a construção de uma imagem mais positiva dos Estados Unidos e para a ampliação de sua capacidade de influir. ${ }^{84}$

Nesse intuito e diante do fracasso das tropas cubanas, treinadas militarmente pelos EUA, contra a guerrilha de Castro, as mudanças foram sendo implantadas - não bastava só investir em armamento e treinar Forças Armadas com vistas a um inimigo externo. A tática oferecida, e que vinha sendo desenhada desde o final da década de 1950, de conceber de

${ }^{83}$ Ata disponível em: http://www.documentosrevelados.com.br/condor-2/operacao-condor/ata-de-fundacao-daoperacao-condor-2/ acesso em 20 de janeiro de 2012 às $19 \mathrm{~h}$.

${ }^{84}$ FICO, Carlos. O golpe de 1964 e o papel do governo dos EUA. In.: FICO, Carlos... [et al.] org. Ditadura e democracia na América Latina. Rio de Janeiro: Editora FGV, 2008. p. 58. 
"algum modo supunha as Forças Armadas latino-americanas como gendarmes a serviço dos interesses dos Estados Unidos. Grande quantidade de militares latino-americanos seria treinada em unidades militares nos Estados Unidos ou na Escola das Américas". ${ }^{85}$

O Brasil, em 1964, estava em uma situação política ambígua: a pressão no populismo brasileiro vinha de uma boa parte dos segmentos da sociedade, com uma forte tendência de revolta sindical e camponesa. Essa situação, agregada à importância geopolítica do Brasil para a América Latina, tornava decisiva a intervenção militar - de fato, esta ocorreu o apoio dos Estados Unidos na sua implantação. Não permitir "mais uma Cuba" na América foi parte da estratégia de manter e ampliar seu poderio.

O golpe de 1964 não foi violento no sentido de usar força extrema para a tomada de poder - o Estado foi militarizado com o intuito de regularizar a economia, começar um programa de desenvolvimento econômico nos moldes capitalistas, e combater seu inimigo interno, os comunistas, que ameaçavam a coesão nacional. Quanto a este último aspecto, o país viveu uma situação em que a segurança interna nacional foi uma das protagonistas.

Os anos ditatoriais no Brasil não só reprimiram grupos contrários ao governo militar, como ocasionaram uma estagnação na educação, na cultura e no processo de construção e consolidação da cidadania. Uma parcela significativa dos agentes engajados nessas pautas se identificava ideologicamente com o que podemos chamar de pensamento de esquerda. Por conta do alinhamento ideológico, os grupos de intelectuais foram alvo de retaliações - anos no exílio, torturas, e desaparecimento/morte.

Os "subversivos" eram identificados para além de estarem envolvidos ou não com organizações guerrilheiras; acerca dos intelectuais e artistas, a opressão visava conter desdobramentos "esquerdistas" na sociedade por influência dessas pessoas, formadoras de opinião em algum sentido:

O número de mortos e desaparecidos nos países latino-americanos como conseqüência dessa brutal repressão é ainda hoje imperfeitamente conhecido. Se considerarmos ainda aqueles que permaneceram encarcerados e os que se exilaram, podemos imaginar o significado da "guerra suja" que foi desencadeada em nome da "segurança nacional". Alguns relatos dão conta do tipo de perseguição que atingiu pessoas muito distantes de quaisquer atitudes verdadeiramente ameaçadoras, alcançando artistas, intelectuais, familiares de militantes de partidos políticos, incluindo até crianças (CONADEP, 1985). ${ }^{86}$

\footnotetext{
${ }^{85}$ FICO, Carlos. O golpe de 1964 e o papel do governo dos EUA. In.: FICO, Carlos... [et al.] org. Ditadura e democracia na América Latina. Rio de Janeiro: Editora FGV, 2008. p. 59.

${ }^{86}$ GUAZZELLI, Cesar Augusto Barcellos. História Contemporânea da América Latina: 1960-1990. 2. ed. Porto Alegre: Editora da UFRGS, 2004. p. 33.
} 
O número de mortos e desaparecidos políticos, nos vinte e um anos de ditadura militar no Brasil, segundo dados da Comissão Nacional da Verdade, é de 434 pessoas - destas, 210 estão desaparecidas. É importante ressaltar que esses dados não são estanques, pois ainda há em curso diversas comissões paralelas (estaduais, municipais, de universidades, entre outras) elaborando seus relatórios, e esse número pode ser ampliado. Além de ser impossível quantificar de modo total o número de vítimas, há as que desapareceram e não tinham familiares, ou as que sobreviveram mas, traumatizadas, não relatam sua experiência.

Partindo desse dado quantitativo, pode-se perder a noção qualitativa da questão. Um país territorialmente extenso, no qual em duas décadas de repressão conta com "apenas" quatrocentos mortos e desaparecidos, dá impressão de que, aqui, as atividades repressivas tiveram um cunho ameno de violência - como se o número de vítimas pudesse dimensionar o terror. Nesse ponto, esta Tese concorda com Calveiro:

Diez, veinte, treinta mil torturados, muertos, desaparecidos... En estos rangos las cifras dejan de tener una significación humana. En médio de los grandes volúmenes los hombres se transforman en números constitutivos de una cantidad, es entonces cuando se perde la noción de que se está hablando de individuos. ${ }^{87}$

No Ato Institucional $\mathrm{n}^{\mathrm{o}} 1$, de 9 de abril de 1964, foram definidas as regras que conduziriam a vida política brasileira dali em diante. Nele ficava claro o aspecto da "revolução" feita pelos militares - seria o fim de um governo constitucional, baseado na constituição de 1946, que em seu primeiro artigo proclamava: "Todo Poder emana do povo e em seu nome será exercido"; o povo estava fora de qualquer tipo de participação.

Este foi o primeiro Ato Institucional, e durante a vigência da ditadura militar foram decretados 17 desses atos regulamentados por 104 atos complementares. Passaram a ser criados mecanismos e instituições governamentais que, conforme o discurso do regime, auxiliariam a manter a ordem e a paz social do país, como aponta Quadrat:

Logo nos primeiros dias da ditadura militar, uma das principais características do novo governo começou a ser esboçada. A ditadura brasileira foi obsessivamente preocupada com a formação de um arcabouço legal e jurídico que lhe desse respaldo e legitimidade. A edição de Atos Institucionais ao longo de praticamente todo o período ditatorial é um claro exemplo dessa obsessão. No Brasil ditatorial fazia-se lei para tudo. ${ }^{88}$

\footnotetext{
${ }^{87}$ CALVEIRO, Pilar. Poder y desaparición: los campos de concentración en Argentina. 1. ed. 6. reimp. Buenos Aires: Colihue, 2008. p. 29-30.

${ }^{88}$ QUADRAT, Samantha V. A ditadura civil-militat em tempo de (in)definições (1964-1968). In.: MARTINHO, Francisco C. P. Democracia e ditadura no Brasil. Rio de Janeiro: EdUERJ, 2006. p. 130.
} 
Nos primeiros anos de ditadura, a repressão estava focada em alvos pré-determinados, cidadãos que já tinham um histórico de luta em prol das classes populares e os ditos comunistas (ativos e simpatizantes). Porém, o período mais conturbado da ditadura brasileira estava por vir: de 1969 a 1979, quando os Generais Emílio Garrastazu Médici (1969-1974), e Ernesto Geisel (1974-1979) governaram o país. A perseguição intensificou-se para outras pessoas, que não eram a prioridade, e as eliminações foram executadas com a mobilização de tropas estruturadas, a partir do aparelho repressivo do Estado. Sobre o governo de Médici:

\begin{abstract}
O período foi marcado pelo recrudescimento da repressão política, da censura aos meios de comunicação e pelas denúncias de tortura aos presos políticos. A esquerda intensificou sua ação, com várias organizações optando pela luta armada. Durante o governo Médici, foram combatidos dois focos de guerrilha rural: Ribeira, em São Paulo, e Araguaia, no Pará. Verificou-se também a intensificação da guerrilha urbana, com assaltos a bancos, seqüestro de aviões e de diplomatas estrangeiros. Em resposta à radicalização das organizações armadas de esquerda, o governo transferiu o comando das operações repressivas para a recém-criada Operação Bandeirantes (Oban), em São Paulo, que passou a se chamar Comando de Operações de Defesa Interna (CODI) e coordenava as atividades dos Departamentos de Operações e Informações (DOIs). O aparato repressivo do governo contava, ainda, com os centros de informação das forças armadas: o Ciex, do Exército, o Cenimar, da Marinha, e o Cisa, da Aeronáutica. Nesse período, assistiu-se à desestruturação das organizações de esquerda, com a prisão, exílio ou morte de seus principais líderes. ${ }^{89}$
\end{abstract}

Foi também neste período que os Estados Unidos intensificaram a colaboração para manter o Brasil como um país livre de comunistas. Havia uma aproximação entre Médici e Richard Nixon - presidente dos Estados Unidos entre 1969 e 1974:

A relação entre Nixon e Médici começou de forma desconfiada, e avançou para uma colaboração estreita e freqüente, baseada no sentimento anticomunista de ambos: para ganhar a confiança e a intimidade de Médici, os Estados Unidos deram ao Brasil tratamento de potência emergente e a Médici, de líder influente no mundo. [...] Médici frequentemente alertava Nixon sobre os movimentos subversivos na América Latina. ${ }^{90}$

O arquivo do Conselho de Segurança Nacional de Nixon contém muitos documentos que comprovam a relação com Médici, e apontam também que o Brasil, além de garantir a "segurança nacional" no seu território, estava preocupado com os países vizinhos. Pode-se

\footnotetext{
${ }^{89}$ CASA CIVIL PRESIDÊNCIA DA REPÚBLICA - ARQUIVO NACIONAL. Os presidentes e a ditadura militar. Rio de Janeiro, 2001. p. 32.

${ }^{90}$ COGGIOLA, Oswaldo. Governos militares na América Latina. São Paulo: Contexto, 2001. p. 25.
} 
verificar que Médici não negava informação aos Estados Unidos sobre o que considerava "movimentos suspeitos" na América Latina. ${ }^{91}$

Com esta aproximação, o Brasil se tornou mais que um informante dos americanos; era também colaborador, para a efetivação da militarização do poder na América Latina. A preocupação de que o Brasil e os países latinos se tornassem comunistas era tanto norteamericana quanto do governo militar brasileiro.

Dessa forma, foi alinhavada a implantação de ditaduras militares na América Latina. O Brasil já participava da coreografia ditatorial norte-americana desde o golpe militar em 1964. Na década de 1960, o Brasil passou a reformular seu aparato repressivo e opressor, e na década de 1970 implantam-se no Chile e na Argentina ditaduras de caráter visivelmente contra-revolucionárias. Os anos anteriores foram de prevenção ao comunismo; agora, a "guerra contra os vermelhos" estava declarada e seu agente mais importante encontrava-se no Chile.

\subsubsection{A experiência chilena}

Santiago, Chile, 11 de setembro de 1973: a democracia mais longa e duradoura da América Latina foi derrubada. O general Augusto Pinochet Ugarte, comandante do exército chileno que chefiou a junta militar, tomou o poder, destituindo Salvador Allende, presidente socialista que morreu acossado no Palácio de la Moneda. Este golpe de Estado foi o primeiro ato para o início de uma "guerra ao terrorismo", pois os terroristas, na visão de Pinochet, eram forças políticas com ideologias comunistas.

O Chile foi precursor quando elegeu democraticamente Salvador Allende à Presidência, sendo o primeiro marxista a governar um país ocidental por meio de eleições. Allende defendia a força e a preservação dos valores e tradições democráticas. Quem nomeou Augusto Pinochet chefe do exército foi o próprio Allende.

O Chile era tido como exemplo de democracia, pela sua estabilidade ante a América já convulsionada pelo militarismo. Mas foi justamente o Oficial chileno de maior envergadura que atuou para que o golpe de 1973 ocorresse. Com esse golpe no Chile, as ações dos Estados militarizados atingem outro patamar, de uma luta contra o "terrorismo" dentro dos Estados.

Daí em diante, o Chile começou uma busca intensa aos apoiadores de Allende, em que qualquer cidadão passou a ser alvo dos militares. A execução em massa fez com que a

91 Todos os memorandos desclassificados e que tratam deste tema, onde a autora desta Tese consultou encontram-se disponíveis no link: http://nsarchive.gwu.edu/NSAEBB/NSAEBB282/index.htm 
resistência ao regime fosse curta: mais de mil indivíduos, partidários de Allende, foram “amontoados em campos de concentração improvisados, como o Estádio Nacional de Santiago" $"$. As pessoas eram tiradas de suas casas, torturadas e executadas, e os corpos, geralmente, ocultados:

\footnotetext{
No Chile, nas primeiras semanas depois do golpe de Pinochet, a tristemente célebre 'caravana da morte' - detenção sistemática de ativistas políticos destinados aos campos de concentração e assassinato - impôs torturas indescritíveis e covardes a inúmeros opositores. Sob o regime de Pinochet surgia a figura do 'desaparecido político', o preso não-reconhecido submetido a torturas piores que as da Inquisição, e posteriormente assassinado na clandestinidade. ${ }^{93}$
}

A América Latina estava sendo enclausurada, figurativa e literalmente, para qualquer prática de cunho esquerdista. Livrar-se dos, ditos, comunistas era objetivo dos governos militares - assim, a ordem estaria estabelecida e, junto a ela, a paz social. Devemos nos perguntar: que paz foi esta, ou melhor, quem estaria vivendo em paz? Os cidadãos latinoamericanos viviam em fuga; Pinochet, através de sua varredura anticomunista, passou a agir dentro do seu país e, logo, em toda a América Latina.

\subsubsection{A "reorganização" argentina}

Em 1976, na torrente dos países vizinhos, ocorreu o "processo", assim denominado pela junta militar que deu o golpe, na Argentina - com a justificativa de que a Argentina enfrentava caos econômico, organizações guerrilheiras atuando de modo violento, lutas facciosas e uma disseminação de terror promovida pelos militares. A crise econômica e a desordem social que assolavam a Argentina desde o final da década de 60 foram se agravando, e o Estado perdia paulatinamente o controle da situação. Diversas tentativas de reestruturação econômica foram tentadas até 1976, mas os governos que se sucediam não conseguiam aliviar a tensão.

Seguindo os passos de seus vizinhos, a Argentina viu-se diante de um golpe violento: em 24 de março de 1976, o general Videla ${ }^{94}$ tornou-se presidente. Não foi uma atitude isolada:

\footnotetext{
${ }^{92}$ DINGES, John. Os anos do Condor: uma década de terrorismo internacional no Cone Sul. 1. ed. São Paulo: Companhia das Letras, 2005. p. 20.

${ }^{93}$ COGGIOLA, Oswaldo. Governos militares na América Latina. São Paulo: Contexto, 2001. p. 52.

${ }^{94}$ Chefe da Junta de Reorganização Nacional, que fazia parte junto com Agosti (chefe da Aviação) e Massera (chefe da Marinha), do "trio da morte". Os três haviam assumido o comando militar, que antes era chefiado por Lopez Rega.
} 
O golpe na verdade, foi uma operação integral de repressão, cuidadosamente planejada pela direção das três armas, ensaiada primeiro em Tucumán, onde o Exército intervinha oficialmente desde 1975, e depois executada sistematicamente em todo o país. ${ }^{95}$

Em fevereiro de 1975 foi realizada uma operação na província de Tucumán, região montanhosa do Nordeste da Argentina, e local de grandes vales produtores de açúcar. Ali havia um foco da guerrilha rural do Partido Revolucionário del Pueblo (PRT), que justificou uma ação de luta contra a ação subversiva. Em realidade, em muitos setores da Argentina, o golpe que ocorreu em março de 1976 já vinha sendo articulado, e não foi uma ação sem planejamento. Conforme o relatório do Tribunal Russell $\mathrm{II}^{96}$ :

\begin{abstract}
Em 24 de março de 1976, quando de Buenos Aires começaram a chegar as primeiras notícias do golpe de Estado com que a Junta Militar, dirigida pelo general Jorge Rafael Videla, havia derrubado o governo de Maria Estela Martinez de Perón (Isabelita), alguns suspiraram aliviados. De tal modo estava esfacelada a Argentina de Isabelita (dois assassinatos por dia, cinco mil detentos políticos, $350 \%$ inflação ao ano) que parecia impossível um ulterior agravamento. Agora, há distância de três meses do golpe, mesmo os mais céticos devem mudar de opinião. Se a Argentina estava à beira do abismo, o golpe de Videla a empurrou para dentro dele: 15 mil prisioneiros políticos, 48 partidos postos fora da lei, 150 pessoas assassinadas em poucas semanas. ${ }^{97}$
\end{abstract}

A Argentina foi o último país latino, na década de 1970, a ter sua democracia suspensa, e em apenas sete anos contabiliza-se, conforme instituições de direitos humanos, trinta mil desaparecidos políticos. Os números ajudam a corroborar a informação supracitada, pela qual podemos perceber que as ditaduras implantadas na década de 1970 eram de caráter contrarrevolucionário.

Os desaparecimentos, então, aumentaram significativamente, porque quando uma pessoa é desaparecida não existem provas de execução. O sumiço é um mistério, mas com esta ruptura na Argentina - único país latino onde houve decisão judicial contra o governo

${ }^{95}$ ROMERO, A. Luis. História Contemporânea da Argentina. Rio de Janeiro: Jorge Zahar Ed. 2006. p. 196.

96 Em 1966, Bertrand Russel (prêmio Nobel da Paz) convocou em Londres um Tribunal para os crimes americanos no Vietnã, chamou cerca de quinze pessoas do mundo todo para dicutir questões do Direito Internacional. O Tribunal Russell II teve uma primeira sessão em Roma em 1974 e uma segunda em Bruxelas em 1975, foi uma iniciativa privada de pronunciar sentenças em âmbito internacional contra Estados e chefes de Estado. Adquiriu muito prestígio que passou a ser citado nos tratados de direito internacional e na Comissão das Organizações Unidas dos Direitos Humanos. O Tribunal Russell II em sua terceira sessão, ocorrida em 1976, também em Roma, tratou da repressão na América Latina.

${ }^{97}$ LAFFONT, Roberto; MEYER, Philippe. O exemplo da Argentina. In: TOSI, Giuseppe; FERREIRA, Lúcia de Fátima (orgs.). Contrarrevolução na América Latina: subversão militar e instrumentalização dos sindicatos, da cultura, das Igrejas -Tribunal Russell II. João Pessoa: Editora sa UFPB, 2014. p. 92. 
militar durante o exercício deste - a responsabilidade em relação à vida dos milhares de presos não é de ninguém. Ademais de todo o desrespeito com os direitos humanos, os anos ditatoriais também foram marcados por abusos financeiros:

\begin{abstract}
A "corrupção" foi elevada a níveis estratosféricos, com negociatas, mas também roubo e venda dos bens das pessoas "desaparecidas", sem falar nas mordomias do astronômico orçamento militar, responsável por mais de um quarto da dívida externa do país, que atingiu 45 bilhões de dólares. O Estado, por meio do poder militar, virou literalmente uma máfia. ${ }^{98}$
\end{abstract}

Entende-se aqui por "máfia" uma organização criminosa, em que as atividades estão submetidas a uma direção oculta, que tem por objetivo intervir na sociedade a qual está inserida. E criminosa no sentido de executar tarefas à margem das leis do país de origem de seus membros, exercendo assim atividades ilegais, e que visam os interesses de algum grupo determinado e não o bem comum de toda a sociedade. A mais recente ditadura militar da Argentina foi iniciada em março de 1976. Este não foi o primeiro golpe de Estado sofrido pelos argentinos, mas sem dúvida foi o mais violento, no sentido de todo o aparato repressivo que foi montado e utilizado para combater a ameaça comunista.

Para isto foram desenvolvidas diversas atividades, que consistiam em práticas contra o grande número de "subversivos" atuantes no país. Na Argentina, desde a década de 1960, começaram a surgir organizações guerrilheiras que se articulavam em grupos, dentre os quais os de maior relevância foram os Montoneros $^{99}$ e o Ejército Revolucionario del Pueblo $(\mathrm{ERP})^{100}$, que se fortaleceram a partir de 1967. Ainda coexistiram as Forças Armadas Peronistas (FAP), os Descamisados, as Forças Armadas Revolucionárias (FAR) e as Forças Armadas de Libertação, que foram paulatinamente sendo absorvidos pelos dois grupos mais consistentes.

$\mathrm{Na}$ Argentina, podemos notar uma afluência mais engajada e organizada de grupos que contestavam a ordem estabelecida, com ideologia, de certa forma, coesa dentre os seus grupos, que investiram em uma revolta armada. Mesmo havendo diferenças políticas e teóricas entre estas, a ação armada era, além de desejo, vista como uma solução:

A revolução era vista como algo possível. E, para aqueles que acreditavam numa teoria marxista da história, inevitável. Àquela época, a revolução era uma realidade concreta. Era a vitória de Fidel Castro em Cuba. [..] A revolução era uma ideia para o futuro imediato. [...] Era uma revolução que se espalharia cada vez mais, por

\footnotetext{
${ }^{98}$ COGGIOLA, Oswaldo. Governos militares na América Latina. São Paulo: Contexto, 2001. p. 58.

${ }^{99}$ Surgiu por volta de 1970, a partir do integralismo católico e nacionalista, que se tornou peronista.

${ }^{100}$ Vinculado ao grupo trotskista do Partido Revolucionário dos Trabalhadores.
} 
exemplo, pela ideologia, por uma organização casa-a-casa e fábrica-a-fábrica, e sobretudo - pelo que chamavam la lucha armada, a luta armada. ${ }^{101}$

O golpe na Argentina se aproxima do brasileiro, instaurado em 1964, pelo fato de não ter utilizado a violência no primeiro momento, ou seja, na tomada do poder em si, como no Chile. O governo ditatorial foi acolhido por uma parcela significativa da sociedade, uma vez que a promessa da Junta Militar que operacionalizou o golpe estava centrada no fim do caos econômico e da violência, que era crescente. Como já citado, nos primeiros meses após o golpe, o quadro se agravou. Além de não amainar os índices de violência, o golpe agregou a violência política perpretada pelo Estado.

Um dado relevante é que, quando da reunião que efetivou a Operação Condor, ao contrário dos outros países que estavam sob regimes militares, a Argentina estava sob o governo de Isabel Perón, de caráter democrático:

\begin{abstract}
$\mathrm{O}$ acordo para formar o Condor foi muito provavelmente firmado às escondidas do governo conflituoso de Isabel Perón na Argentina. No final de 1975 e no inicio de 1976, o regime civil estremecia à beira da desintegração, e cedia mais e mais autonomia aos militares. A criação da aliança do Condor foi um dos primeiros passos na estratégia militar de desferir um golpe mortal no caos e terrorismo político argentino que, na visão dos militares, tinha sido gerado pelo peronismo. No mapa da futura ação do Condor, a Argentina devia ser a primeira e maior arena para a operação em múltiplos países. ${ }^{102}$
\end{abstract}

A Argentina militarizada pode ser considerada a arena latino-americana da década de 1970. Para compreendermos este papel, tem de se destacar duas peculiaridades: a primeira é de que a Argentina foi o último país latino-americano na década de 1970 a aderir ao governo militar. A segunda é a mobilização esquerdista na Argentina, que estava muito empenhada e organizada em sua causa, disposta a lutar em favor do que consideravam ser o melhor para o país.

Esta mobilização esquerdista e o número elevado de pessoas contrárias à ditadura foram justificativas utilizadas pelo governo militar para a violência empregada. "A repressão foi, em suma, uma ação sistemática realizada pelo estado. Tratou-se de uma ação terrorista, dividida em quatro momentos principais: seqüestro, tortura, prisão e execução". ${ }^{103}$ Após o golpe as ações do Estado para eliminar os "guerrilheiros" passaram a ser sistematizadas, confirmando que os militares já planejavam a tomada de poder, bem como denotando as

\footnotetext{
${ }^{101}$ DINGES, John. Os anos do Condor: uma década de terrorismo internacional no Cone Sul. 1. ed. São Paulo: Companhia das Letras, 2005. p. 74-75.

${ }^{102}$ Ibidem, p. 204-205.

${ }^{103}$ ROMERO, A. Luis. História Contemporânea da Argentina. Rio de Janeiro: Jorge Zahar Ed. 2006. p. 197.
} 
atitudes que seriam executadas para colocar o país em ordem, já que, para os militares, a Argentina estava desorganizada.

Neste sentido, uma prática política de duas faces foi utilizada; o governo militar tenta mostrar-se brando, quando todas as suas atitudes foram apresentadas como institucionalizadas e legalizadas pela Junta Militar - desconsiderando que, no momento em que rompe com a legislação democrática anterior, torna todas as ações ilegais - não há legalidade em um Estado a priori ilegal, já que está contra a Constituição até o golpe vigente. Ao mesmo tempo, o governo instaurado agiu clandestinamente:

\begin{abstract}
Por trás das faces amenas dos novos governantes militares estava uma ditadura muito pior - em vários graus de magnitude - do que o experimento de Pinochet na erradicação anticomunista. Um sistema de extermínio clandestino operava por toda a nação desde que os militares tinham assumido a guerra contra os subversivos no outubro anterior. ${ }^{104}$

Apesar de a Junta Militar ter estabelecido a pena de morte, esta nunca foi aplicada, e todas as execuções foram clandestinas. Às vezes, os cadáveres apareciam na rua, como se tivessem morrido em confrontos ou tentativas de fuga. [...] Mas, na maioria dos casos, os cadáveres eram ocultados, enterrados em cemitérios como indigentes, queimados em valas coletivas [...]. Assim, não houve mortos, apenas "desaparecidos". 105
\end{abstract}

A perseguição oculta foi a tática governamental latino-americana da década de 1970 para efetuar a "limpeza" dos comunistas em seus países, amplamente apoiada pela também clandestina articulação da Operação Condor.

Quanto aos militantes de esquerda, ou melhor, às pessoas que agiam contra o governo militar, estavam dispostos a morrer pela causa ou em defesa dos seus "companheiros". A realidade era tal que estes militantes planejavam suicídios para evitar a tortura e/ou para não delatar seus pares, como é retratado, por exemplo, no caso de Pelado José ${ }^{106}$ por Mariano:

Conferiu os documentos e se a pastilha de cianureto de potássio estava no interior do cinto da calça. Com a mão direita, praticou a retirada do veneno em direção à boca. Se fosse descoberto, cravaria o dente no plástico branco com bordas vermelhas do invólucro do veneno. Deixaria a pastilha à mercê do canino mais eficiente, o direito. Preferia o suicídio do que ser preso - um mandamento da organização. ${ }^{107}$

\footnotetext{
${ }^{104}$ DINGES, John. Os anos do Condor: uma década de terrorismo internacional no Cone Sul. 1. ed. São Paulo: Companhia das Letras, 2005. p. 209.

${ }^{105}$ ROMERO, A. Luis. História Contemporânea da Argentina. Rio de Janeiro: Jorge Zahar Ed. 2006. p. 198199.

${ }^{106}$ Eduardo Astiz, chamado pelo codinome de pelado José, guerrilheiro montonero que recebeu treinamento com guerrilheiros cubanos, ao narrar a sua chegada no Rio de Janeiro, em 23 de abril de 1979.

${ }^{107}$ MARIANO, S. Nilson. Montoneros no Brasil - Terrorismo de Estado no seqüestro-desaparecimento de seis guerrilheiros argentinos. Porto Alegre: PUCRS, 2006. Dissertação, Mestrado em História - PUCRS. Porto Alegre, p. 60.
} 
Com isso, podemos perceber a dimensão da repressão a que estes grupos estavam submetidos. Era frequente entre os guerrilheiros a técnica das pílulas de cianureto como forma de resistência à repressão - mesmo que não as utilizassem, grande parte dos guerrilheiros tinha junto de si as pastilhas.

Quanto à primeira peculiaridade, em relação à Argentina ter sido o último país, no recorte desta Tese, que sucumbiu ao militarismo, é possível compreender tal característica como elucidativa, no que se refere ao número elevado de mortos e desaparecidos em apenas sete anos, de governo ditatorial, neste país. Os estimados trinta mil mortos/desparecidos na Argentina não eram somente cidadãos argentinos, mas pessoas de diversas nacionalidades: uruguaios, paraguaios, chilenos, brasileiros, além de cidadãos europeus e alguns com dupla cidadania.

A repressão estava interpenetrando todo o continente, e as pessoas estavam em busca de duas coisas: continuar atuando contra estes regimes e garantir a sua integridade física e moral. Isso fez com que muitos procurassem refúgio na Argentina:

Com a restauração populista de Perón, a Argentina se tornou um porto para os refugiados políticos e as organizações revolucionárias. À medida que os ditadores militares obstruíam a política num país após o outro, bolivianos, uruguaios, paraguaios, brasileiros e agora chilenos, todos afluíam para aproveitar a liberdade inebriante na Argentina. [...] Além dos ativistas realmente envolvidos com as organizações subterrâneas, milhares de refugiados políticos dos países vizinhos estavam vivendo na Argentina à época do golpe. ${ }^{108}$

Mas, com o golpe de 1976, o cerco estava fechado. A presença de ditaduras em quase toda a América Latina e uma audaciosa - no sentido de formalizar a repressão conjunta - e eficaz articulação através da Operação Condor fizeram com que a Argentina se tornasse palco de graves violações aos direitos humanos: aquele governo prendeu, torturou, executou e ocultou corpos de pessoas de diferentes nacionalidades. Nesta tese o entendimento é do protagonismo da Argentina, nas ações praticadas por meio da Operação Condor, após o golpe de 24 de março de 1976. A violência policial já estava atuando desde 1974 contra os montoneros, principalmente, mas também reprimindo e aniquilando com outros grupos guerrilheiros. Diante dos golpes em cadeia no Cone Sul, as alternativas de fuga se tornavam cada vez mais escassas, o fluxo de exílio se direcionou, após o golpe chileno em 1973, para a Argentina, portanto após o golpe de 1976 o número de estrangeiros no país era alto, e isto reverberou no elevado número de mortos e desaparecidos da ditadura Argentina. As

${ }^{108}$ DINGES, John. Os anos do Condor: uma década de terrorismo internacional no Cone Sul. 1. ed. São Paulo: Companhia das Letras, 2005. p. 209. 
articulações que possibilitaram esse protagonismo da Argentina, no âmbito da Operação Condor são o tema do capítulo a seguir. 


\section{O "PACTO DO CONE SUL"}

Os serviços de informação do Brasil, Argentina e Chile - também conhecidos como, serviços de inteligência, órgãos de segurança ou repressão, ou ainda serviços secretos - foram criados geralmente, no contexto da Doutrina de Segurança Nacional. Esses serviços faziam parte do núcleo estatal, o núcleo de contenção do que chamavam de subversão. Tiveram papel importante no exercício do terror estatal, no período compreendido nesta Tese. Antunes, analisou em perspectiva comparada os serviços de informações de Brasil, Argentina e Chile. Conforme suas pesquisas, a ditadura na Argentina teve como característica um nível baixo de institucionalização, devido a fragmentação e falta de legitimidade do governo militar. Quanto ao caso brasileiro, ela afirma que houve um alto índice de institucionalização, devido uma separação entre governo, as instituições militares e o apoio de importantes setores da elite política/econômica. Já o regime chileno teve, no entendimento da autora, um nível muito elevado de institucionalização, devido principalmente pela personificação do poder em uma figura política, o general Pinochet, isso amalgamado com uma forte repressão e apoio de parcelas da elite política chilena. ${ }^{109}$

Apesar das particularidades de cada país, visto que as circunstâncias de cada Estado reverberam em um tipo específico de construto político, econômico, social e cultural - bem como com a absorção de influências externas - é consenso que havia traços comuns diante do quadro latino de repressão e violência. Essas similitudes e diferenças foram absorvidas, estruturadas e formalizadas nas conexões repressivas estabelecidas na Operação Condor. A significativa mudança que o Operativo Condor traz é a formalização destas ações de colaborações de cunho repressivo.

A Operação Condor foi uma rede de colaboração repressiva e contou com apoio dos Estados Unidos, que "proporcionó inspiración, finaciamiento y asistencia técnica a la represión y pudo haber plantado las semillas de la Operación Condor. La CIA promovió una mayor coordinación entre los servicios de inteligencia de la región". ${ }^{110}$ Calloni, em 1999 em sua obra mais emblemática -, não afirmava categoricamente que os EUA tinham colaborado com a Operação Condor. A autora apontava essa hipótese, confirmada anos depois por meio dos documentos descartados dos Estados Unidos.

\footnotetext{
${ }^{109}$ ANTUNES, Priscila. Ditaduras militares e institucionalização dos serviços de informações na Argentina, no Brasil e no Chile. In.: FICO... [et al.] Ditadura e democracia na América Latina: balanço histórico e perspectivas. Rio de Janeiro: Editora FGV, 2008. p. 239-240.

110 CALLONI, Stella. Operación Condor: los años del lobo. 1. ed. Buenos Aires: Peña Lillo Ediciones Continente, 1999. p. 17.
} 
O apoio dos EUA no Plano Condor foi importante na parte de estruturação e logística, bem como na questão tecnológica; a gestão era chilena, sob a supervisão de Contreras. As atividades eram executadas entre os países do Cone Sul participantes, e a documentação aponta que, em geral, os EUA sabiam das atividades repressivas. ${ }^{111}$ Dinges, em 2005, também apresenta documentos dos Estados Unidos que corroboram a hipótese que Calloni apresentou.

O dia 19 de dezembro de 1970 é a data de um documento, expedido pela embaixada do Brasil na Argentina - sob custódia do Arquivo Nacional, no fundo do Serviço Nacional de Informações -, que trata da cooperação repressiva entre agentes do Estado naquele ano. É um relato sobre o caso do ex-militar brasileiro Jeferson Cardim de Alencar Osorio e seu filho. ${ }^{112}$ Sabe-se que brasileiros eram monitorados no exterior, como demonstram os casos emblemáticos de Leonel Brizola e João Goulart, bem como os de diversos outros atores de destaque - ou não - no cenário político. Jeferson Cardim foi preso e torturado na Argentina, antes de ser encaminhado ao Brasil. Nesse informe enviado pela embaixada brasileira está comprovado que, ao menos nesse caso, o Estado brasileiro sabia o que acontecia em território estrangeiro e cooperava em atividades repressivas.

Conforme os documentos, era de conhecimento do Estado brasileiro, nos mínimos detalhes, a data da viagem, como ela seria feita, com que carro, e quem estaria acompanhando Jeferson Cardim. Destaca-se:

[...] pude saber que a chegada estava prevista para às 15.00 hs o que me dava mais tempo para acionar uma cooperação da Direção de Coordenação Federal, órgão de inteligência da Polícia Federal Argentina, cujo titular da Subcomissária de Assuntos Estrangeiros tem matido [sic] comigo o mais estreito e eficiente contato. Tendo informado ao subcomissário em causa dos detalhes que permitiriam a identificação do grupo, pude acompanhar, indo ao porto e permanecendo afastado do local de desembarque, a interceptação do carro e os movimentos que se seguiram até o embarque do grupo em um carro da Polícia [Argentina] e sua saída do recinto seguido pelo Aero Willis. Tudo indicava que os elementos da Coordenação Federal, haviam preferido deter o grupo ao invés de acompanhá-lo a fim de levantar os contatos que iriam manter. ${ }^{13}$

111 Grande parte destes documentos encontra-se no acervo da Comissão Nacional da Verdade. Disponível em: http://www.cnv.gov.br/index.php/2-uncategorised/417-operacao-condor-e-a-ditadura-no-brasil-analise-dedocumentos-desclassificados

112 Sobre essa documentação encontra-se na internet duas referências. Uma publicada em novembro de 2012, de maneira bem sucinta, é apenas uma indicação da existência desses documentos, no site da revista Época, disponível no link: http://colunas.revistaepoca.globo.com/felipepatury/tag/jefferson-cardim-osorio/ acessado em 16 de janeiro de 2013 às 9h40min. E uma reportagem mais abrangente, que cita os documentos, e disponibiliza uma parte deles no site Página 12 disponível em: http://www.pagina12.com.ar/diario/deportes/8-226505-2013-08-11.html acessado em 12 de agosto de 2013 às $17 \mathrm{~h} 30 \mathrm{~min}$.

113 BRASIL. Casa Civil da Presidência da República. Arquivo Nacional. ACE 32.368. Prisão de Jeferson Cardim e seu filho. 20/01/1971. 
A prisão de Jerferson ocorreu em dezembro de 1970, cinco anos antes da formalização da Operação Condor . Conforme a documentação e o relato do ex-preso político Jarbas Silva Marques, Jeferson chegou da Argentina muito debilitado pela tortura. Segundo Jarbas, ambos dividiram uma cela no Brasil. A colaboração entre Brasil, Chile e Argentina é explícita neste caso, o qual demonstra que já havia uma estrutura em funcionamento, que antecedeu a Operação Condor.

São inúmeras as vítimas da Operação Condor; tantos outros foram sequestrados, e muitos tiveram seus filhos roubados pelos agentes da repressão. É o caso de Pablo Gérman Athanasiu Laschan, que, por meio de um exame de DNA, confirmou, aos 37 anos, as suspeitas de que era filho de desaparecidos. Pablo é o neto 109, divulgado no começo de agosto de 2013 pelas Avós da Praça de Maio. Filho de chilenos que se exilaram na Argentina após o golpe de Pinochet, Pablo nasceu em outubro de 1975 e foi sequestrado junto com seus pais em abril de 1976. Conforme a coletiva de imprensa das Avós da Praça de Maio, o sequestro de Pablo e seus pais foi fruto da Operação Condor. O homem que registrou Pablo como filho mantinha relações estreitas com o regime militar, e está preso por crimes lesahumanidade. ${ }^{114}$

Sabe-se que as ditaduras não agiam isoladamente, visto que os distintos regimes governamentais, em diferentes graus, relacionam-se no campo politico, econômico e social com outros países. O que surpreende não é a proximidade entre os agentes do Estado; surpreende a colaboração com métodos violentos: ações contra seus cidadãos em diferentes países, com apoio logístico e colaboração mútua entre Estados, violando todos os direitos do homem.

\subsection{Terror em rede internacional}

A efetivação formal da Operação Condor aconteceu em Santiago do Chile, em 28 de novembro de 1975, durante o Primeiro Encontro de Trabalho Interamericano sobre Inteligência Nacional, e contou com a participação de oficiais da Argentina, Paraguai, Uruguai, Bolívia e Brasil. Durante esse encontro foi assinada a ata pelas delegações participantes - apenas a delegação do Brasil não assinou. Para esse fato, Mariano levanta a

114 
hipótese de discrição brasileira, ${ }^{115}$ mas também é factível concluir que não interessava ao regime militar brasileiro ser signatário da referida ata. Afinal, no Brasil o regime buscava a distensão, com o discurso de abertura política, e, ademais, também não interessaria, no campo diplomático, colocar o país como coadjuvante no sistema repressivo, enquanto os militares brasileiros defendiam um Brasil potência.

Nesta ocasião estiveram presentes os seguintes agentes: Jorge Casas - Argentina; Carlos Mena Burgos - Bolívia; Manuel Contreras Sepúlveda - Chile; José Fons - Uruguai e Benito Guanes Serrano - Paraguai. ${ }^{116}$ O Brasil enviou dois representantes, porém como observadores, por isso a ata de formalização não conta com a assinatura de brasileiros. Conforme Luiz Claudio Cunha, os enviados para essa reunião foram Flavio de Marco e Thaumaturgo Sotero Vaz, ambos militares do Centro de Informações do Exército (CIE) e participantes da Guerrilha do Araguaia. ${ }^{117}$

Nota-se, portanto, a participação dos altos escalões de todos os governos que fariam parte deste sistema articulado no Chile, através de Manuel Contreras; era um acordo sem precedentes, no sentido de criar laços colaborativos de repressão entre países conhecidamente de relações estremecidas:

\begin{abstract}
Não foi uma aliança entre vizinhos fraternos. Em nome da causa comum, precisaram superar antigas rivalidades. Por exemplo: o Chile, que propôs a Operação Condor, enfrentava a animosidade da Bolívia desde que lhe cortara o acesso ao Oceano Pacífico e tinha disputas de fronteira com a Argentina pela posse do Canal de Beagle. [...] O Brasil também era visto com desconfianças. Na época, a Argentina não assimilara a Itaipu Binacional (hidrelétrica construída na fronteira com o Paraguai, a partir de 1973). ${ }^{118}$
\end{abstract}

Mas, diante do inimigo comum, infiltrado em toda a América Latina, ajudar-se-ão mutuamente, "deixando de lado" por um período as suas desavenças, em nome do "bemestar" do povo latino americano:

A aliança do Condor nasceu dos instintos agressivos dos líderes militares que se viam diante de um conflito de âmbito mundial. Eles usavam o termo Terceira Guerra Mundial sem ironia ou ressalvas. Mais do que uma guerra de tropas irregulares extinguindo levantes ocasionais de guerrilha, o eixo do Cone Sul estava equipado

\footnotetext{
${ }^{115}$ MARIANO, S. Nilson. Montoneros no Brasil - Terrorismo de Estado no seqüestro-desaparecimento de seis guerrilheiros argentinos. Porto Alegre: PUCRS, 2006. Dissertação, Mestrado em História - PUCRS. Porto Alegre, 2006. P. 19.

${ }^{116}$ Ata disponível em: http://www.documentosrevelados.com.br/condor-2/operacao-condor/ata-de-fundacao-daoperacao-condor-2/ acesso em 20 de janeiro de 2012 às $19 \mathrm{~h}$.

117 Disponível em: http://www.viomundo.com.br/politica/luiz-claudio-cunha-as-garras-do-brasil-na-operacaocondor.html acesso em 08 de julho de 2012 às $10 \mathrm{~h}$.

${ }^{118}$ MARIANO, op. cit., p. 17.
} 
para projetar seu poder no exterior [...] As forças então unidas a fim de preservar o "modo de vida ocidental". 119

No Arquivo Nacional em Brasília-DF, onde estão os documentos do Serviço Nacional de Informações (SNI), nada consta sobre a participação brasileira; pelo contrário, dos poucos documentos lá encontrados que tratam sobre a Operação Condor é omitido o envolvimento do país no grupo. Este silêncio do arquivo, denota que a intenção era de ocultar a participação nessas atividades, mas não consegue servir como prova de que o regime militar delas não participou pois, afinal, existem os fatos, a saber, dois casos demonstrados nesta Tese.

Um documento datado de 01/11/1985 relata as atividades do $\mathrm{M}^{120}$ na fronteira brasileira, e seu resumo diz:

\begin{abstract}
Atividades do M19, grupo subversivo que atua na Colômbia, consoante com os dados obtidos em operações militares realizadas pelo exército brasileiro, em set. 85, na fronteira noroeste do Amazonas. Destaca-se que anteriormente, as Forças Armadas do Peru e da Colômbia desenvolveram a chamada Operação Condor, uma operação militar conjunta de combate aos grupos subversivos atuantes naqueles países, da qual pode se constatar a internacionalização do M19 e SL. Verifica-se que: a atuação do M19 na área de fronteira com o Brasil tem sido passiva e sem grandes atividades, não havendo indícios de que se processe do lado brasileiro $[\ldots] .{ }^{121}$
\end{abstract}

A participação brasileira na Operação Condor é consenso entre os pesquisadores acerca do tema, principalmente após a desclassificação de documentos dos Estados Unidos. Vários desses documentos apontam as conexões com intuito repressivo com intensa participação brasileira. E, mesmo antes dessa desclassificação, documentos que apontavam a participação do Brasil nas atividades do Condor foram encontrados no Arquivo do Terror, no Paraguai.

O Arquivo do Terror foi descoberto pelo advogado Martim Almada, vítima da repressão no Paraguai. Foram encontrados milhares de documentos que registraram a repressão paraguaia. Em 2009 o Arquivo do Terror foi aberto ao público, e em seu acervo encontram-se documentos que demonstram a efetiva participação brasileira na repressão além das fronteiras:

${ }^{119}$ DINGES, John. Os anos do Condor: uma década de terrorismo internacional no Cone Sul. 1. ed. São Paulo: Companhia das Letras, 2005. p. 191.

120 Após a vitória apertada do conservador Misael Pastrana nas eleições presidenciais de abril de 1970, os partidários do ex-ditador Rojas Pinilla acusam a Frente Nacional de fraude e formam a organização guerrilheira Movimento Revolucionário 19 de Abril (M-19). A este se juntam dissidentes das Forças Armadas Revolucionárias da Colômbia (FARC).

${ }^{121}$ BRASIL. Casa Civil da Presidência da República. Arquivo Nacional. ACE L00058919. Atividades do M19 na fronteira. 01/11/1985. 
Alli se encontraron las invitaciones para la reunión inaugural de Operativo Cóndor [...], la idea original del jefe de la Dina chilena, Manuel Contreras; las atividades desarrolhadas por las delegaciones participantes; y hasta los códigos secretos de comunicación que serían utilizados. A partir de esas constataciones, investigadores de todo el mundo recurrieron a dichos archivos para intentar completar el rompecabezas, confirmar sus teorías y documentar sus publicaciones. ${ }^{122}$

Como citado anteriormente, a Operação Condor compreendia três fases, sendo que a primeira tinha o intuito de trocar informações entre os países participantes: Chile, Uruguai, Argentina, Bolívia, Paraguai e Brasil, através das suas agências de inteligência. A coordenação ficou centralizada no Chile, sob as ordens do coronel do Exército Manuel Contreras, que era também chefe da Dirección de Inteligencia Nacional. Foi utilizada nesta primeira fase a melhor tecnologia da época, incluindo telex, computadores e microfilmes:

Un informe del Comité de Relaciones del Senado de Estados Unidos en 1979, fundamentado en los archivos de la CIA, explicaba que la Operación tenía três fases: y que fue planeada en 1974, después del asesinato de un embajador de Bolivia en París, de un funcionário chileno en Medio Oriente y de un agregado uruguayo (Trabal) en París. Cóndor planeó una operación destinada a asesinar tres izquierdistas en Europa $[\ldots]^{123}$

Neste banco de dados encontravam-se informações a respeito dos cidadãos considerados subversivos e organizações que exercessem algum tipo de atividade "suspeita" nos países latinos. Para isso, foi criado um sistema de telex chamado Condortel, no qual cada país tinha um número identificador: Condor um (Chile, sede do Condor), Condor dois (Argentina), Condor três (Uruguai), Condor quatro (Paraguai) e Condor cinco (Bolívia). O Brasil, o Equador e o Peru se juntaram mais tarde à organização como Condor seis, sete e oito:

À medida que os subversivos e seus aliados se moviam de país para país, as informações sobre seu paradeiro e atividades deviam ser introduzidas no banco de dados central pelos serviços de Inteligência. [...] Cada país fornecia, e cada país recebia as informações, usando o sistema de comunicação. ${ }^{124}$

${ }^{122}$ PA, Alfredo Boccia. Los "archivos del horror"del Paraguay: los papeles que resignificaron la memoria del stronismo. In: FICO ... [et al.] Ditadura e democracia na América Latina: balanço histórico e perspectivas. Rio de Janeiro: Editora FGV, 2008. p. 39.

${ }^{123}$ CALLONI, Stella. Operación Condor: los años del lobo. 1. ed. Buenos Aires: Peña Lillo Ediciones Continente, 1999. p. 24.

${ }^{124}$ DINGES, John. Os anos do Condor: uma década de terrorismo internacional no Cone Sul. 1. ed. São Paulo: Companhia das Letras, 2005. p. 188. 
Caracterizada a primeira fase como de informação, a segunda e a terceira foram (ou deveriam ser) de operações, ou seja, de ações. Ressalta-se novamente que as fases não se distinguem, ou seja, laboraram em conjunto. Em meados dos anos 1970 na América Latina, operação, na linguagem dos aparelhos repressivos de Estado, significava sequestro, interrogatório sob tortura e extermínio. A fase três pode ser considerada a mais audaciosa, já que previa ações fora da América Latina.

Nas conexões repressivas impetradas pelo Condor não houve limites, ou respeito aos direitos humanos. O motivo principal para o foco de análise dessa Tese ser na logística da fase dois é devido ao hibridismo entre a primeira e a segunda fase, relacionados especialmente com a implantação da ditadura militar Argentina. "As operações de Condor, tanto da Fase Dois como da Fase Três, atingiram o clímax no período posterior ao golpe militar na Argentina em março de 1976". ${ }^{125}$

A operacionalização dos planos do Condor foi um processo rápido. Analisando as datas, temos sua formalização no final de 1975, e no primeiro semestre de 1976 sua segunda fase já estava em pleno funcionamento. Notamos assim que esta operação de intuito internacional já vinha sendo articulada, pelo menos, desde 1973, quando Pinochet tomou o poder no Chile e nomeou Manuel Contreras chefe do Exército. A reunião de 1975 com a assinatura dos "sócios" desse empreendimento foi apenas a oficialização do que já ocorria de maneira informal - como indicam os casos de colaboração com intuito repressivo, explicitada, por exemplo, na prisão de Jeferson Cardim, caso tratado no capítulo anterior desta Tese.

Ou seja, ao menos cinco anos antes da assinatura do convênio repressivo, os agentes do Estado já agiam em conjunto. Outros dois casos são emblemáticos das conexões repressivas no Cone Sul: Edmur Péricles Camargo e Joaquim Pires Cerveira.

Edmur Péricles Camargo, paulista, foi dirigente da organização Marx, Mao, Marighella e Guevara (M3G). Atuou no Partido Comunista Brasileiro (PCB), no Sindicato dos Armadores (RJ) e também no jornal A Tribuna, em Porto Alegre-RS. Em 1964, por causa do golpe no Brasil, foi para o Uruguai e fez treinamento guerrilheiro com os Tupamaros. Em 1967, quando retornou ao Brasil, Edmur foi militante na Ação Libertadora Nacional (ALN) e mantinha contatos com a Vanguarda Armada Revolucionária Palmares (VAR-Palmares). Foi preso em 1970 e banido do Brasil em janeiro de 1971, na ocasião do sequestro de Giovanni Enrico Bucher, embaixador suíço no Brasil. Edmur foi para o Chile, um caminho seguido por

${ }^{125}$ DINGES, John. Os anos do Condor: uma década de terrorismo internacional no Cone Sul. 1. ed. São Paulo: Companhia das Letras, 2005. p. 39. 
muitos brasileiros banidos ou no exílio forçado. Seu desaparecimento foi em 16 de junho de 1971, quando saía de Santiago do Chile com destino final em Montevideo.

As investigações da Comissão Nacional da Verdade (CNV) apontaram que a prisão de Edmur ocorreu no Aeroporto de Ezeiza em Buenos Aires, em ação da polícia argentina, que o entregou para as autoridades brasileiras. A prisão de Edmur só foi possível pela colaboração entre os organismos de repressão do Brasil, Argentina e Uruguai, com participação efetiva da chancelaria brasileira nesses países. Um avião da Força Aérea Brasileira (FAB) levou Edmur para o Rio de Janeiro na madrugada de 17 de junho de 1971. ${ }^{126}$ A CNV responsabilizou 16 pessoas pelo desaparecimento de Edmur ${ }^{127}$. As conclusões para o caso são:

\begin{abstract}
Diante das investigações realizadas, conclui-se que Edmur Péricles Camargo desapareceu a partir de ações perpetradas por agentes do Estado brasileiro, em contexto de sistemáticas violações de direitos humanos promovidas pela ditadura militar, implantada no país a partir de abril de 1964. As circunstâncias do desaparecimento de Edmur Péricles Camargo evidenciam a articulação entre os serviços policiais brasileiros e argentinos e o trabalho clandestino desses para monitorar, perseguir e sequestrar exilados políticos no Cone Sul. ${ }^{128}$
\end{abstract}

Após o ato institucional no 1 (1964), Joaquim Pires Cerveira, então major do Exército Brasileiro, passou à reserva. Foi preso em outubro de 1965, e em 1967 absolvido do crime de subversão. Em 1970 foi preso novamente e banido do país. Em 11 de dezembro de 1973, foi preso em Buenos Aires, torturado e trazido para o Brasil, em uma operação conjunta dos órgãos repressivos brasileiros e argentinos ${ }^{129}$.

O caso de Joaquim Pires Cerveira é considerado um dos primeiros atos de conexão repressiva no cone sul - tese advogada por diversas organizações de direitos humanos no Brasil e exterior. A tese "Memória da Dor: A Operação Condor no Brasil (1973-1985)"

${ }^{126}$ Relatório da Comissão Nacional da Verdade - GT Operação Condor com os detalhes e documentos do caso de Edmur disponível em: http://www.cnv.gov.br/images/pdf/publicacaoes/claudio/publicacoes_edmur_pericles.pdf.

${ }^{127}$ Presidente da República do Brasil: general de Exército Emilio Garrastazú Medici, Ministro da Aeronáutica: major-brigadeiro Marcio de Souza e Mello, Adido da Aeronáutica junto à Embaixada do Brasil em Buenos Aires: Miguel Cunha Lanna, Chefe do Serviço Nacional de Informações (SNI): general de Divisão Carlos Alberto Fontoura, Ministro das Relações Exteriores: Mário Gibson Barbosa, Embaixador do Brasil na Argentina: Antônio Francisco Azeredo da Silveira, Chefe do Ciex: Paulo Sérgio Nery, Ministro da Marinha: almirante de Esquadra Adalberto de Barros Nunes, Adido Naval junto à Embaixada do Brasil no Chile: Benedito Jordão de Andrade, Embaixador do Brasil no Chile: Antônio Cândido Câmara Canto, Cônsul Geral do Brasil no Chile: Melillo Moreira de Mello, Embaixador do Brasil no Uruguai: Luiz Leivas Bastian Pinto, Ministro do Exército: general de Exército Orlando Beckmann Geisel, Chefe do Estado Maior do Exército: Murillo Bastos do Valle e Silva, Adido do Exército junto à Embaixada do Brasil em Montevidéu: coronel Moacyr Pereira, Adido do Exército junto à Embaixada do Brasil em Buenos Aires: coronel Sebastião José Ramos de Castro. Disponível em: http://verdadeaberta.org/mortos-desaparecidos/edmur-pericles-camargo.

${ }^{128}$ Relatório final Comissão da Verdade. Mortos e Desaparecidos 1970-1971. p. 357.

${ }^{129}$ Informações disponíveis em: http://www.torturanuncamaisrj.org.br/MDDetalhes.asp?CodMortosDesaparecidos=271. 
defendida no Programa de Pós-Graduação em História da USP de Neusa Maria Romanzini Pires Cerveira em 2007, tem como objeto de estudo esse caso, e conta com vasta documentação acerca das atividades repressivas colaborativas antes de 1975, além de defender a hipótese de que o Brasil foi o articulador da Operação Condor ${ }^{130} \mathrm{O}$ desaparecimento de Cerveira suscita algumas polêmicas: o ex-delegado de polícia Cláudio Guerra declarou que o corpo do major foi incinerado em uma usina de açúcar em Campos-RJ - versão contestada por Neusa Cerveira. De fato, a justificativa de Guerra para ter reconhecido Cerveira é frágil: o agente afirmou que após ver fotos, recentemente, de desaparecidos políticos, identificou Cerveira como um dos corpos que ele levou para a usina. $^{131}$

Todos os relatos sobre este caso dão conta de que Cerveira estava com o rosto desfigurado após as inúmeras torturas sofridas na Argentina e no Brasil, e muito diferente das fotos que estão publicadas - inclusive, em nota no livro de Guerra consta uma descrição de Cerveira, e que o mesmo estaria com o rosto "inchado, esburacado e muito sangue na cabeça" ${ }^{132}$. O caso de desaparecimento do Major Cerveira é citado no livro de Calloni, e aponta que ele foi preso em 1973 em Buenos Aires, assim como Edmur Péricles Camargo. Cerveira foi trazido para o Brasil, e possivelmente morto, em 1974, no Rio de Janeiro. ${ }^{133}$ Seu desaparecimento foi em 5 de dezembro de 1973 em Buenos Aires, quando estava acompanhado de João Batista Rita. O relatório da CNV afirma que há indícios de que Cerveira morreu nas dependências do DOI-CODI/I Exército depois de torturado ${ }^{134}$. A conclusão sobre o desaparecimento do major pela Comissão da Verdade é:

Diante das investigações realizadas, conclui-se que Joaquim Pires Cerveira foi sequestrado, torturado e desapareceu em ações perpetradas por agentes do Estado brasileiro, em contexto de sistemáticas violações de direitos humanos promovidas pela ditadura militar, implantada no país a partir de abril de 1964. As circunstâncias do desaparecimento de Joaquim Pires Cerveira comprovam a coordenação entre os serviços de informações militares brasileiros e argentinos e o trabalho clandestino deles para monitorar, perseguir e sequestrar exilados políticos no Cone Sul. ${ }^{135}$

\footnotetext{
${ }^{130}$ As informações citadas aqui são de entrevistas concedidas pela pesquisadora, de conversas informais que tive com Neusa via internet e do seguinte artigo: CERVEIRA, Neusa R. P. Rumo à Operação Condor -Ditadura, tortura e outros crimes. Projeto História, São Paulo, n. 38, p. 97-118, jun. 2009.

131 GUERRA, C.; NETTO, M.; MEDEIROS, R. Memórias de uma guerra suja. Rio de Janeiro: Topbooks, 2012. p. 226.

${ }^{132}$ Ibidem, p. 227.

133 CALLONI, Stella. Operación Condor: los años del lobo. 1. ed. Buenos Aires: Peña Lillo Ediciones Continente, 1999. p. 123.

${ }^{134}$ Relatório final Comissão da Verdade. Mortos e Desaparecidos junho de 1973- abril de 1974. p. 337-360.

${ }^{135}$ Ibidem, p. 349.
} 
A resolução final da CNV para esses casos se difere em uma palavra: as circusntâncias de desaparecimento de Edmur apontam "evidências" de coordenação entre serviços de informação do Brasil e Argentina. Já o caso de Cerveira "comprova” essa coordenação, uma vez que o substrato de documentos sobre esse desaparecimento é mais substancial que o de Edmur. Em ambos a CNV não classifica como Operação Condor, mas sim como coordenação repressiva.

Por meio desses casos, fica explícito que as conexões repressivas não começaram com a acta de 1975; esta tese compreende a concepção de articulação com intuito repressivo além fronteiras, antes da oficialização do Plano Condor:

\footnotetext{
Ao longo dos anos, especialmente a partir da década de 50, os laços de camaradagem e cooperação entre as Forças Armadas foram estreitados através da convivência nas academias militares de treinamento tanto no Panamá como nos Estados Unidos. A divulgação da ideologia da segurança nacional e a crença na necessidade de combater o comunismo na América Latina acabou por aproximar os oficiais e as próprias instituições. ${ }^{136}$
}

Era consenso entre os líderes do Cone Sul a existência de uma ameaça real de comunismo para a região. A possibilidade de impedir uma possível tomada de poder pelo comunismo fez com que seus governos ditatoriais se unissem em torno de um objetivo comum: acabar com essa ameaça. Para isto usaram a força, eliminando os que se atreveram a lutar contra o autoritarismo imposto. Essas eliminações serviram, também, como alerta para as pessoas que, por alguma razão, tivessem intenções de engajar-se ou apoiar alguma causa de ideologia difusa da imposta pelo governo.

A união entre Brasil, Argentina e Chile durante os Anos do Condor foi não apenas de troca de informações, mas também de práticas. Brasil e Chile tiveram uma aproximação intensa durante esses anos; mesmo com a negativa oficial brasileira podemos constatar que as relações foram intensificadas no período do Condor, e que o Brasil agiu nesta aliança contra os, supostos, inimigos de cada Estado, e colaborou sistematicamente com o Chile, bem como com a Argentina.

136 QUADRAT, Samantha Viz. Operação Condor: o "Mercosul” do Terror. Estudos Ibero-Americanos, PUCRS, Porto Alegre, v. XXVIII, n. 1, p. 167-182, jun. 2002. 
Em 16 de setembro de 1975, a DINA encaminhou um memorando para o Presidente da República do Brasil (Ernesto Geisel) ${ }^{137}$, o qual trata de um acordo firmado entre esta instituição e o Brasil. Foi solicitado, pelo Chile, a quantia de "600 mil dólares", para que fossem atendidas quatro demandas:

1) Aumentar o número de agentes da DINA no exterior - seriam dez pessoas distribuídas em alguns países: duas no Perú, duas no Brasil, duas na Argentina, e uma pessoa na Venezuela, Costa Rica, Bélgica e Itália;

2) Gastos adicionais para a neutralização de adversários no exterior (México, Argentina, Costa Rica, Estados Unidos, França e Itália);

3) Despesas para operações com intuito de ajudar partidários do governo chileno no Perú, que estariam atuando na "Aramada Peruana" e nos jornais "Equis" e "Operación Libre";

4) Custo de oficiais da DINA que estavam em Manaus, fazendo treinamento antiguerrilheiro. ${ }^{138}$

A segunda fase da Operação Condor consistiu no seguinte procedimento: depois de identificados os suspeitos, em geral pelos "marcadores"" interrogatório e a tortura, executados comumente em um centro de detenção clandestino, que poderia estar situado em casas, depósitos, galpões ou fazendas - alugadas ou cedidas para o Exército, bem como nas próprias instalações das instituições militares.

As operações executadas no âmbito da Operação Condor foram clandestinas; a clandestinidade nas ações do Estado denota a intenção deste em mascarar suas práticas, deixando claro para a sociedade que estava "agindo", mantendo boa parte da população coagida, porém sem deixar prova material destas ações, já que os corpos dos executados não

${ }^{137}$ O governo de Geisel é tido como de abertura política, de transição para a democracia, uma transição segura. Fato dado na historiografia acerca do período que a estrutura repressiva não foi desmontada, portanto, apesar da propaganda de "abertura" política, os meios para conter a "subversão" continuaram estruturados e agindo.

138 Telegrama disponível no banco de dados do site Documentos Revelados. http://www.documentosrevelados.com.br/condor-2/operacao-condor/documento-revela-cooperacao-entre-asditaduras-do-brasil-e-do-chile/

139 Ativistas de esquerda, que ao ser capturados, se dispunham auxiliar os sequestradores em troca da sua sobrevivência, permaneciam nas fronteiras para identificar os suspeitos, eram geralmente os considerados menos resistentes" ou os que tinham informações estratégicas sobre os grupos guerrilheiros. Submetidos no primeiro momento a tortura física e psicológica, porém "poupados" quando decidiam colaborar fornecendo informações. Conhecidos também como "quebrados" uma alusão a sua condição física e psicológica diante da tortura. Uma discussão mais aprofundada sobre os marcadores está no sexto capítulo desta tese, quando trata-se dos casos da fronteira Uruguaiana-Paso de los Libres, mais especificamente o papel de Silvia Tolchinsky, que atuou na aduana integrada do Brasil e Argentina durante as mais recentes ditaduras. 
foram entregues às famílias. Constando como desaparecidos, o Estado eximia-se de dar algum tipo de informação formal sobre o paradeiro destas pessoas.

Em geral, estas prisões clandestinas na Argentina passaram a surgir logo após o golpe de 1976 - os argentinos foram mais discretos que os chilenos, com suas execuções em massa no Estádio Nacional de Santiago, em 1973. Os argentinos optaram por manter pequenas fazendas que não ficavam longe de pontos estratégicos como Buenos Aires e das fronteiras ${ }^{140}$.

\subsection{O pacto do Cone Sul}

Durante pesquisas no Arquivo Nacional de Brasília, a busca pela palavra-chave “operação condor" indicou um arquivo ${ }^{141}$ não digitalizado. $\mathrm{O}$ assunto nos registros do SNI estava como "correspondência do Movimento Peronista Montonero", e a descrição, conforme o SNI, "documentação remetida ao Sindicato dos Metalúrgicos de Belo Horizonte-MG”. Foi postada da agência dos correios da Praça XV no Rio de Janeiro no dia 18 de abril de 1981, e havia uma nota afirmando que, conforme as normas de distribuição, o endereço do remetente era fictício.

Trata-se de um livro, intitulado "Diante dos acordos Videla-Figueiredo: o pacto do cone sul", publicação do Movimiento Peronista Montonero Conducción Nacional. É uma publicação da condução nacional dos Montoneros, elaborada pela revista Vencer, em outubro de 1980.

Esse livro trata do "namoro" (como a publicação se refere aos acordos entre esses países) das ditaduras do Brasil e Argentina, representadas naquele momento por Videla e Figueiredo. Conforme a publicação, essa aproximação se deu por conta de uma crise econômica das ditaduras, onde alianças se produzem com interesse em manter-se no poder. $\mathrm{O}$ impulso para essas alianças foi ofertado por investidores estrangeiros alemães, franceses e norte-americanos. Os protagonistas desses acordos seriam as oligarquias do pampa argentino e a burguesia paulista, que atuariam, principalmente, na importação de produtos excedentes dos países impulsionadores; pretendiam, com isso, uma reestruturação regional da América Latina, usando estratégias econômicas, políticas e militares, e intentavam agir construindo um mercado comum no litoral atlântico sul.

\footnotetext{
${ }^{140}$ Buenos Aires por ser a capital federal onde residiam centenas de refugiados políticos, seguidamente se encontravam os mais procurados guerrilheiros na capital. As fronteiras, por ser rota de fuga.

141 BRASIL. Casa Civil da Presidência da República. Arquivo Nacional. Correspondência do Movimento Peronista Montonero. AC_ACE 16680_81.01/06/1981.
} 
Essa articulação, segundo o livro, seria um perigo econômico para todos os povos latinos, uma ameaça das oligarquias aos alijados da sociedade capitalista, ou seja, os explorados. Quando outros Estados legitimavam as articulações (do Brasil e da Argentina), estavam apoiando o sistema ditatorial vigente, bem como um "projeto oligárquicomonopólico reacionário e belicista". Ainda conforme essa publicação, países como Estados Unidos e Inglaterra apoiavam tais empreitadas com interesses financeiros.

Os montoneros acreditavam não ser uma aliança invencível, e que poderiam derrotá-la por meio da união dos povos latinos. Nesse ponto, são explicitadas algumas formas de como conduzir essa união dos povos, o poder dos povos para os povos. Em síntese, a orientação é uma união interna e externa de resistência aos sistemas vigentes.

Uma das justificativas utilizadas por militares para a colaboração entre os aparatos estatais para conter a militância contrária às ditaduras foi a de que essas já estavam articuladas em torno de um projeto para o Cone Sul. Uma articulação internacional, dos Estados, com intuito de defender suas nações do comunismo era necessária, já que os "subversivos" estariam articulados em âmbito internacional. Ou seja, a já conhecida argumentação utilizada para justificar a violência interna, a segurança nacional, agora para além das fronteiras.

Essa articulação de "subversivos" é conhecida, e nunca foi negada pelos militantes ao contrário dos Estados, que ocultaram uma parte significativa de suas atividades repressivas, de modo que alguns ainda negam atualmente suas ações para por fim aos grupos de oposição aos seus governos. Pode-se perceber que a obra citada foi elaborada com intuito de alertar os povos latinos para as alianças econômicas que poderiam prejudicar os excluídos do sistema capitalista. O livro, publicado originalmente em espanhol e traduzido para o português, indica que as esquerdas estavam preocupadas com o que acontecia além de suas fronteiras. É assinado pela Condución Nacional del Movimiento Peronista Montonero: Mario Eduardo Firmenich, Oscar R. Bidegain, Raúl C. Yager, Rodolfo J. Puiggrós, Roberto C. Perdia, Ricardo Obregón Cano, Fernando Vaca Narvaja e Eduardo Pereira.

Ao analisar esta obra, apesar de tratar de temas, em amplitude, de acordos políticos e econômicos, que eram de conhecimento razoavelmente difundido, os indícios nos mostram que também se tratou de pactos com intuito repressivo. Como, quando comenta o golpe boliviano em 1980:

[...] é nesta lógica da estratégia econômica e política dos acordos Videla-Figueiredo que se produziu o golpe de Estado criminoso do General Garcia Meza, na Bolívia, já não é nenhum segredo a participação aberta do Exército Argentino no mencionado golpe, não somente como instigador, tampouco somente como apoio logístico, mas 
como oficiais do campo de batalha da "guerra suja", ou seja, como diretores da tortura, sequestros assassinatos". ${ }^{142}$

Esta afirmação tem uma nota de rodapé, que relata uma ação ocorrida em uma mina em San José (Bolívia), em 18 de julho de 1980, em que um grupo de paramilitares dirigidos por vários argentinos atacou trabalhadores destruindo o aparelho de rádio e atirando contra a bandeira da Bolívia. Também dá conta de que 50 oficiais do Serviço de Inteligência do Exército Argentino ingressaram na Bolívia como "agregados especiais" da embaixada Argentina em La Paz. ${ }^{143}$

Sobre o Terrorismo de Estado, o livro lembra que Videla agradeceu publicamente Figueiredo em Buenos Aires, pela ajuda na "guerra suja" contra a "subversão"; indica também uma internacionalização do terror estatal quando cita em nota de rodapé de um plano apresentado na Colômbia, no final de 1979, pelo General Viola, então Comandante-em-chefe do Exército Argentino:

[...] em 7 de novembro de 1979, em uma sessão da XIII Conferência de Exércitos realizada em Bogotá, Colômbia, [...] tenente-general Roberto Eduardo Viola pronunciou um discurso que se converteu em ponto capital para a reunião e que, em um de seus pontos propunha: 'articular a concentração de esforços dos exércitos americanos na luta contra a subversão marxista, sem limites de fronteiras ou espaço'. ${ }^{144}$

Para exemplificar como reagir nessa conjuntura, os autores oferecem um exemplo, que, segundo sua visão, fez com que essas atividades clandestinas tivessem visibilidade internacional, e, dessa forma, ajudassem a agregar simpatizantes para a causa e denunciar os crimes velados dos Estados articulados. Trata-se do sequestro de montoneros no Peru em 12 de julho de $1980 .{ }^{145}$ Nesta ocasião, Maria Inês Raverta, Noemí Esther Gianotti de Molfino, Júlio César Ramirez e Frederico Frías Alberga foram sequestrados, por meio de uma ação conjunta entre as forças armadas da Argentina e Peru.

Em 21 de julho de 1980 o corpo de Noemí foi encontrado na Espanha. Segundo reportagem $^{146}$ veiculada em 7 de agosto de 1980 pelo jornal El País, a morte de Noemí foi um crime político - oficialmente, foi informado que teria sido de causas naturais, versão contestada na crônica. Baseando-se em informações divulgadas em 6 de agosto de 1980 pela

${ }^{142}$ BRASIL. Casa Civil da Presidência da República. Arquivo Nacional. Correspondência do Movimento Peronista Motonero. AC_ACE 16680_81.01/06/1981.p.9.

${ }^{143}$ Ibidem, p. 32.

${ }^{144}$ Idem, p. 33.

${ }^{145}$ Idem, p. 34.

146 Arquivo digital do jornal argentino El País, disponível em: http://elpais.com/diario/1980/08/07/internacional/334447219_850215.html 
Comisión Argentina de Derechos Humanos (Cadhu), que contradiziam a nota oficial da embaixada Argentina em Madrid, este sequestro ocorrido no Peru foi parte das investigações promovidas pela Justiça Italiana, que apurava crimes contra cidadãos italianos na Operação Condor. Noemí era ativa integrante das Mães da Praça de Maio, já que, de seus seis filhos, quatro estavam envolvidos com política militante. Uma de suas filhas, que era dirigente da Juventude Montonera, desapareceu junto com o marido, bem como dois de seus netos, que foram encontrados três anos depois. Tinha também uma filha exilada em Paris por motivos políticos, e seu filho mais velho foi preso e só obteve liberdade após o fim do regime militar na Argentina. ${ }^{147}$ Utilizar a exposição desses sequestros, desaparecimentos e mortes, com colaboração repressiva entre Estados, foi uma das formas propostas neste livro pela Condução Montonera para tentar vencer essa "aliança latina contra os povos".

\subsection{O Rio Grande do Sul na Operação Condor}

As fronteiras do Rio Grande do Sul com Argentina e Uruguai, durante a ditadura militar, principalmente, foram estritamente vigiadas. "Cruzar a fronteira" não era tarefa hercúlea, porém com grandes chances de ser capturado. Além das fronteiras secas - ChuyChuí, Rivera-Santana do Livramento - e das cidades que tem ligação por meio de pontes, são notórios os "cruzes" feitos por cidadãos que dispõe de pequenos barcos, para todo o tipo de atividade lícita e ilícita - e utilizados, em diversos períodos, tanto por quem está fugindo quanto por quem está perseguindo.

Essa localização estratégica permitiu que muitas colaborações fossem executadas, não apenas de repressão, mas de solidariedade. Certamente, o caso mais emblemático das garras do Condor ocorreu em Porto Alegre: o sequestro frustrado de Lílian Celiberti e Universindo Diaz, que desvelou publicamente as conexões repressivas internacionais.

Lílian e Universindo militavam no Partido por la Victória del Pueblo (PVP), e estavam em Porto Alegre com seus dois filhos, Camilo e Francesca. Em novembro de 1978, uma ação conjunta entre brasileiros e uruguaios os sequestrou e os levou para o Palácio da Polícia, onde sofreram torturas. Após essa detenção, foram conduzidos até a fronteira do Brasil com o Uruguai. Diante da grande possibilidade de morte, Lílian, em resistência, pediu que entregassem seus filhos para os avós. Em contrapartida, ela disse que tinha um encontro com uma pessoa importante de sua organização, em Porto Alegre.

${ }^{147}$ Informações acerca do caso de Noemí disponíveis em: http://www.urgente24.com/208030-baltasar-garzonque-la-sombra-de-noemi-molfino-le-alcance. 
Universindo e as crianças foram para Montevidéu, e Lílian voltou para Porto Alegre. A intenção dos repressores era montar uma armadilha. Porém, avisado por um telefonema anônimo, o jornalista Luiz Claudio Cunha e o fotógrafo João Batista Scalco chegaram de surpresa no apartamento em que Lílian estava presa. Sobre essa passagem, Luiz Cláudio Cunha afirmou que ele é um sobrevivente do Condor, que olhou nos olhos do Condor. ${ }^{148}$

O "sequestro dos uruguaios", como foi chamado o notório caso, teve grande repercussão na mídia nacional e internacional. Diante da pressão, a ditadura uruguaia teve de recuar. Lílian e Universindo apareceram presos no Uruguai. Um “combinado" entre os Estados tentou que se mostrasse uma história muito diferente da realmente ocorrida, a conhecida "farsa de Bagé". 149

Apesar dos esforços em esconder as atividades criminosas, nesta ocasião não foi possível. O "sequestro dos uruguaios" comprovou que o Brasil colaborava nas conexões repressivas - nas palavras de Jair Krischke, "foi o primeiro caso em todo o Cone Sul no qual foram exibidas as vísceras do Condor, comprovando cabalmente a sua existência e seu modo de agir". ${ }^{150}$

Antes desse emblemático caso, Fernandez, que trata em sua tese de doutoramento sobre as experiências de argentinos no Rio Grande do Sul, lança luz em outro caso de articulação repressiva internacional aos moldes do Condor. Trata-se da prisão do engenheiro Carlos Claret. Em setembro de 1978, na cidade de Passo Fundo, militares do Exército Brasileiro, policiais civis e federais realizaram uma operação para prender Claret. Cidadão argentino, estava morando no Brasil havia dois anos, com visto de turista que constantemente tinha de ser renovado - um dos motivos pelo qual foi viver em Passo Fundo-RS, cidade próxima da fronteira, para que as viagens de três em três meses não fossem tão cansativas, mas distante dos "olhos" da ditadura Argentina.

${ }^{148}$ Fala de Luiz Cláudio Cunha no Seminário Operação Condor, promovido pela Câmara dos Deputados em 05 de Julho de 2012 em Brasília-DF.

${ }^{149}$ Sobre o caso Lílian Celiberti e Universindo Diaz, discussões avançadas e densas podem ser encontradas nos seguintes trabalhos: CUNHA, Luiz Cláudio. Operação Condor. O Sequestro dos Uruguaios. Uma reportagem dos tempos da ditadura. Porto Alegre: L\&PM, 2008; MITCHELL, José. Segredos à direita e à esquerda na ditadura militar. Porto Alegre: RBS Publicações, 2007. PADRÓS, E. Conexão repressiva internacional: o Rio Grande do Sul e o Brasil na rota do Condor. In: PADRÓS, Enrique Serra et al. (Orgs.). A ditadura de Segurança Nacional no Rio Grande do Sul (1964-1985): história e memória. Conexão Repressiva e Operação Condor. Porto Alegre: Corag, 2009. v. 3. REIS, Ramiro José. Operação Condor e o sequestro dos uruguaios nas ruas de um porto não muito alegre. Porto Alegre: UFRGS, 2012 Dissertação (Mestrado em História) - Programa de Pós-Graduação em História da UFRGS. Universidade Federal do Rio Grande do Sul, Porto Alegre, 2012.

${ }^{150}$ KRISCHKE, Jair. O Brasil inspirou a Operação Condor. In.: SILVA, Haike R. Kleber (Org.). A luta pela anistia. São Paulo: IMESP, 2010. 
Claret saiu da Argentina por conta da repressão imposta pelos militares. Participou da Juventude Peronista, mas não era militante ativo; recebeu muitos argentinos que também procuravam se proteger do Estado vindo para o Brasil. Quando estava estabilizado em Passo Fundo, acreditou que seria oportuno regularizar sua situação no país, pedindo um visto de residência. Poucos dias após realizar o pedido de documentação no consulado argentino, foi preso e levado para um quartel de Passo Fundo. Seguiu para as dependências da Polícia Federal em Porto Alegre, onde foi mantido preso, interrogado e torturado por brasileiros e argentinos. Foi salvo por uma rede de solidariedade: a empresa em que trabalhava em Passo Fundo contratou advogados, foram acionadas a Conferência dos Bispos do Brasil, a Comissão Justiça e Paz e o Alto Comissariado da Organização das Nações Unidas para Refugiados (ACNUR), e Jair Krischke. Claret foi para o exílio na Suécia, junto com sua esposa e filhos. $^{151}$

O relatório da Comissão Nacional da Verdade apontou que o Rio Grande do Sul contou com 39 centros de prisão e tortura, durante a mais recente ditadura civil-militar. Uma das maiores estruturas repressivas no Brasil: a quantidade de locais utilizados para executar violações aos direitos humanos supera o número de Minas Gerais, São Paulo e Rio de Janeiro, estados considerados estratégicos para a repressão.

Delegacias de Polícia Civil, quartéis da Brigada Militar e do Exército, e unidades da Polícia Federal foram utilizadas para prender, interrogar e torturar presos políticos. Conforme o levantamento da CNV, esses locais funcionaram em 16 cidades: Três Passos, Frederico Westphalen, Palmeira das Missões, São Borja, Alegrete, Santa Maria, São Gabriel, Santa do Livramento, Rio Grande, Guaíba, Porto Alegre, Charqueadas, Canoas, Caxias do Sul, São Leopoldo e Viamão.

\footnotetext{
${ }^{151}$ Sobre este caso, Fernandez traz uma análise detalhada acerca de todas as circunstâncias, desde a trajetória de Carlos Claret como especificidades de sua prisão e das colaborações repressivas e de solidariedade. Como não é objeto desta Tese, cf. FERNANDEZ, 2011. FERNANDEZ, Jorge C. Anclaos en Brasil: a presença argentina no Rio Grande do Sul (1966-1989). Porto Alegre: UFRGS, 2011 Tese (Doutorado em História) Programa de Pós-Graduação em História da UFRGS. Universidade Federal do Rio Grande do Sul, Porto Alegre, 2011.
} 


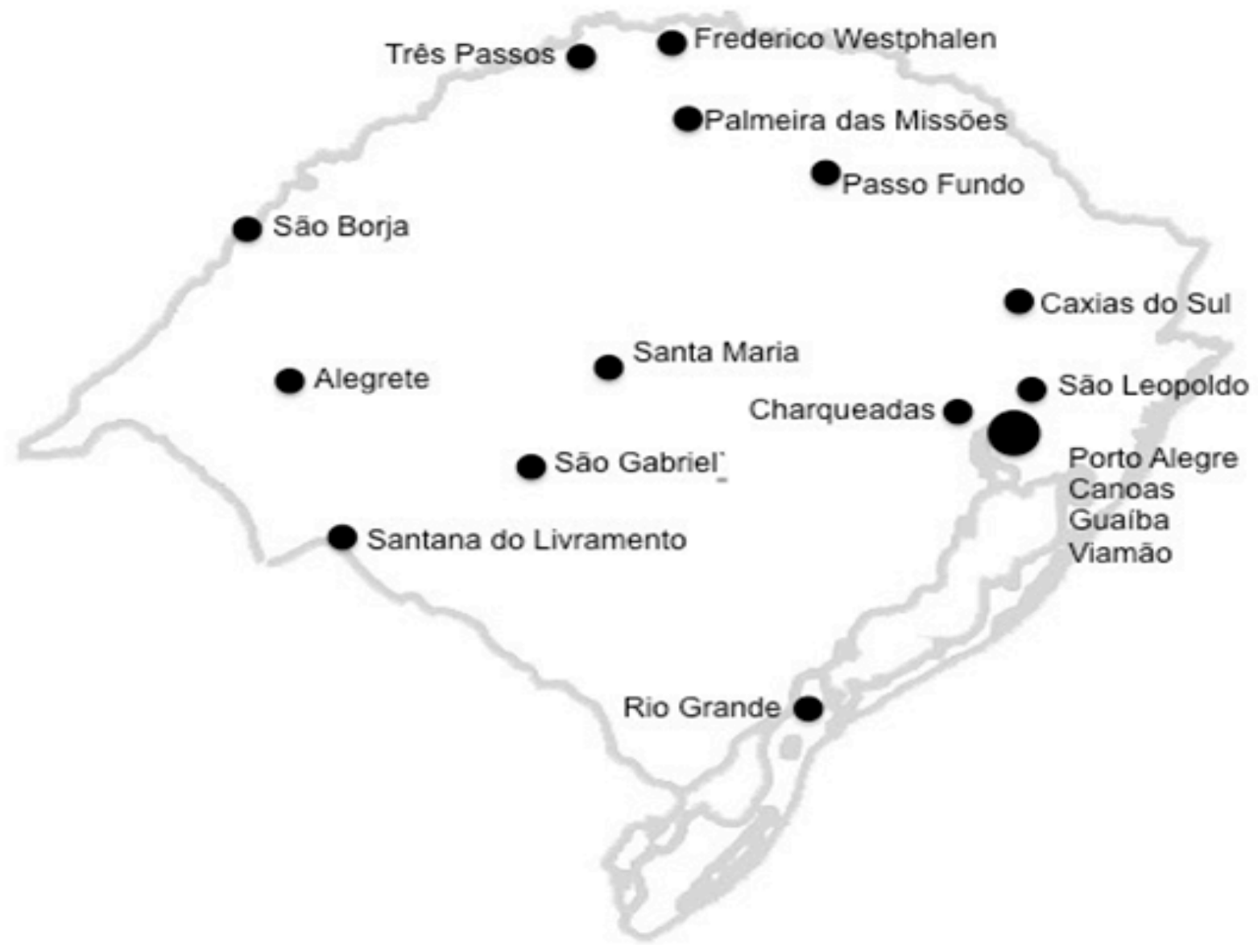

Figura 1 - Mapa das prisões e centros de interrogatórios no Rio Grande do Sul.

Fonte: Adaptado de Relatório Final da CNV (2014).

Além da região metropolitana, pode-se perceber que toda a faixa de fronteira do Rio Grande do Sul com Argentina e Uruguai estava sob controle. Essas unidades foram sendo instaladas paulatinamente, principalmente após 1970. Em abril deste ano, o cônsul americano em Porto Alegre, Curtis Carly Cutter, sofreu uma tentativa de sequestro por um grupo da VPR. O cônsul escapou do sequestro; após esse episódio, ainda no mesmo mês, o major do CIE do Rio de Janeiro Paulo Malhães e o sargento Clodoaldo Cabral foram enviados ao Rio Grande do Sul. Apontados, pelo relatório da CNV, como dois dos maiores especialistas em tortura, assassinato e ocultação de cadáver, Malhães e Cabral ensinaram técnicas aos agentes da repressão gaúchos. No seu depoimento na CNV, o major - que chegou a coronel do Exército - declarou ser amigo de Pedro Seelig, delegado do DOPS e um dos mais conhecidos torturadores que atuou no Rio Grande do Sul. ${ }^{152}$

${ }^{152}$ Brasil. Comissão Nacional da Verdade. Relatório/Comissão Nacional da Verdade. - Brasília: CNV, 2014. Volume I. Tomo II. Parte IV Dinâmica das graves violações de direitos humanos: Casos emblemáticos, locais e autores. O Judiciário. Capítulo 16. A autoria das graves violações de Direitos Humanos. 
A Comissão Nacional da Verdade listou no relatório final 377 agentes da repressão. Destes, ao menos dezenove estão diretamente ligados ao aparato repressivo gaúcho:

Quadro 1 - Lista de agentes da repressão ligados ao aparato repressivo gaúcho.

\begin{tabular}{|c|c|}
\hline Nome & Atividade \\
\hline Alberi Vieira dos Santos & $\begin{array}{l}\text { Sargento da Brigada Militar. Participou de detenções ilegais, execuções, } \\
\text { desaparecimentos e ocultação de cadáveres. }\end{array}$ \\
\hline Arthur da Costa e Silva & Foi presidente da República entre 1967 e 1969. Gaúcho de Taquari. \\
\hline Átila Rohrsetzer & Coronel do Exército. \\
\hline Carlos Alberto Brilhante Ustra & $\begin{array}{l}\text { Coronel do Exército comandou o Doi-Codi do II Exército de } 1970 \text { a } \\
1974 .\end{array}$ \\
\hline Carlos Alberto da Fontoura & General do Exército, chefe do SNI de 1969 a 1974. \\
\hline Carlos Alberto Ponzi & $\begin{array}{l}\text { Coronel do Exército, comandou a agência do SNI em Porto Alegre entre } \\
\text { o final da década de } 1970 \text { e início da de } 1980 .\end{array}$ \\
\hline Emilio Garrastazú Medici & General do Exército, presidente de 1969 a 1974. \\
\hline Enir Barcelos da Silva & Delegado de polícia, trabalhou no DOPS/RS entre 1965 e 1967. \\
\hline Ernesto Beckmann Geisel & $\begin{array}{l}\text { General do Exército e presidente da República de } 15 \text { de março de } 1974 \text { a } \\
15 \text { de março de } 1979 .\end{array}$ \\
\hline Firmino Peres Rodrigues & Delegado de polícia civil \\
\hline Golbery do Couto e Silva & $\begin{array}{l}\text { Comandou o SNI de } 1964 \text { a } 1967 . \text { Chefe do gabinete civil de } 1974 \text { a } \\
1981 .\end{array}$ \\
\hline João Oswaldo Leivas Job & $\begin{array}{l}\text { Coronel do Exército e secretário de Segurança do Rio Grande do Sul de } \\
1979 \text { a } 1982 . \text { Participou do sequestro dos uruguaios. }\end{array}$ \\
\hline José Morsch & Delegado de polícia e diretor-substituto do DOPS/RS. \\
\hline Luiz Carlos Menna Barreto & Tenente-coronel do Exército \\
\hline Luiz Macksen de Castro Rodrigues & Superintendente da Polícia Federal do Rio Grande do Sul em 1978. \\
\hline Marco Aurélio da Silva Reis & Delegado de polícia, serviu no DOPS no Rio Grande do Sul. \\
\hline Orlando Beckmann Geisel & $\begin{array}{l}\text { General do Exército e ministro do Exército de novembro de } 1969 \text { a } \\
\text { março de } 1974 .\end{array}$ \\
\hline Paulo Malhães & $\begin{array}{l}\text { O coronel serviu no Centro de Informações do Exército com intensa } \\
\text { participação em atividades de repressão em Estados como Rio de Janeiro } \\
\text { e Rio Grande do Sul — onde atuou na Capital e em Três Passos. }\end{array}$ \\
\hline Pedro Carlos Seelig & $\begin{array}{l}\text { Delegado de polícia, serviu no Dops no Rio Grande do Sul. Teve } \\
\text { participação em casos de detenção ilegal, tortura e execução. }\end{array}$ \\
\hline
\end{tabular}

Fonte: Adaptado de Relatório Final da CNV (2014).

Os gaúchos tiveram um papel destacado na estrutura repressiva brasileira durante a ditadura civil-militar: presidentes, ministros e emblemáticos violadores de direitos humanos. No Rio Grande do Sul, foi montado um sistema de repressão eficiente, executado por 
militares em conjunto com a Secretaria Estadual de Segurança. Golbery do Couto Silva, que além de chefiar o Serviço Nacional de Informações (SNI) defendia a doutrina de segurança nacional, sendo um dos expoentes desse debate no Brasil, que proporcionou a militarização da polícia, que passou a atuar como agente da repressão militar.

Foram criados, os Destacamentos de Operações de Informação (DOI), entre 1970 e 1974, a partir da Operação Bandeirante (OBAN). O objetivo do DOI-CODI era o de investigar, prender, interrogar e analisar informações sobre os "subversivos". O DOI-CDI Foi instalado em São Paulo, Rio de Janeiro, Recife, Brasília, Belo Horizonte, Salvador, Belém, Curitiba e Porto Alegre, consideradas as principais capitais do país.

Em Porto Alegre, apesar da existência do DOI, o mais importante articulador e implementador do Terrorismo de Estado foi o Departamento de Ordem Social e Política - o que não significa que não agissem isoladamente. No interior do Rio Grande do Sul funcionavam, na Polícia Civil, as Seções de Ordem Política e Social (SOPS) subordinadas ao DOPS/RS que enviavam informações para a sede em Porto Alegre.

Conforme analisado por Bauer, o DOPS/RS, após o golpe de 1964, adquiriu um caráter repressivo amparado na Doutrina de Segurança Nacional, havendo uma militarização desta instituição e suas práticas de polícia política aplicadas foram práticas de Terrorismo de Estado, nos anos da mais recente ditadura brasileira. Ainda conforme esta autora, as ações repressivas desta instituição, não estavam restritas ao Rio Grande do Sul, mas "tendo o órgão agido em colaboração e cooperação com os demais regimes de segurança nacional do Cone Sul, desde a instauração da ditadura brasileira, até momentos em que a coordenação repressiva encontrava-se no seu auge, como durante a Operação Condor". ${ }^{153}$ Embora não tenham sido encontradas referências diretas entre os casos analisados nesta Tese ou atuação do DOPS/RS - como no caso do sequestro de Lilian e Universindo -, as evidências, pela atuação destes órgãos e pela hierarquia do aparato repressivo, permitem concluir que este órgão acompanhou o que ocorreu em Uruguaiana e Paso de los Libres no período estudado nesta Tese.

O Rio Grande do Sul não pode ser visto apenas no espaço territorial brasileiro, ao se analisar seu papel na estrutura repressiva. É preciso ampliar o olhar para entender que a sua relevância no quesito "segurança nacional", e todo o aparato repressivo montado, resulta em sua localização estratégica. Nesse caso, o Rio Grande do Sul precisa ser analisado sob a

${ }^{153}$ BAUER, Caroline Silveira. Avenida João Pessoa, 2050 - 3o andar: terrorismo de Estado e ação de polícia política do Departamento de Ordem Política e Social do Rio Grande do Sul (1964-1982). Dissertação de mestrado Programa de Pós-Graduação em História da Universidade Federal do Rio Grande do Sul. UFRGS, Porto Alegre, 2006. 
perspectiva do Cone Sul, uma perspectiva regional.

O Rio Grande do Sul se constituiu, desde o início da sua existência, como ponta de lança do império brasileiro e os Estados platinos. O fato de possuir simultaneamente fronteira com Argentina e Uruguai deu a esse estado uma configuração e um protagonismo político-estratégico muito particular, especialmente diante de processos e contextos de tensão ou de aproximação entre o Brasil e os países citados. $^{154}$

O Rio Grande do Sul serviu de rota, ponto de passagem, para cidadãos que estavam em fuga das ditaduras do Cone Sul. A fronteira Uruguaiana-Paso de los Libres, por suas características geográficas e logísticas, apresentou-se como uma das alternativas mais viáveis para que essa fuga, como se demonstrará no próximo capítulo desta Tese.

${ }^{154}$ PADRÓS, Enrique Serra; VIVAR, Jorge Eduardo Enríquez. Memórias da resistência e da solidariedade: o Movimento de Justiça e Direitos Humanos contra as ditaduras do Cone Sul e sua conexão repressiva. Porto Alegre: Ed. ASF, 2013. p. 27. 


\section{FRONTEIRA E CONEXÕES NA/DE FRONTEIRA}

Yo no sé dónde soy, mi casa está en la frontera, y las fronteras se mueven, como las banderas. ${ }^{155}$

As fronteiras são regiões peculiares que afetam e transformam as sociedades limítrofes de diversas formas, oferecendo uma moldura específica e complexa para cada um desses locais de contato e também de separação. Há quem sinta repulsa, bem como os que se encantam. Cada "passo" de fronteira se construiu particularmente em seu Estado, bem como em conjunto com seu vizinho. Portanto, para tratar da fronteira que é o local onde ocorreram os casos analisados nesta Tese, é necessário um olhar específico e pontual.

Neste capítulo, as questões abordadas são: como essa fronteira foi constituída e vivenciada; quais suas peculiaridades; que conjunto de motivos a colocaram como um dos locais de colaboração (de solidariedade e de repressão) durante os últimos regimes militares no Brasil e Argentina; como se constitui essa fronteira, para que se alcance quem transitava, e como se movia neste local; e de que modo as instituições atuaram por meio de seus agentes e instituições na fronteira Uruguaiana-Paso de los Libres. E por fim, como se entende a fronteira enquanto conceito nesta Tese.

\subsection{Aspectos da fronteira Uruguaiana-Pasos de Los Libres}

Advoga esta Tese que as relações de fronteira vivenciadas entre Uruguaiana e Paso de los Libres são de integração, e que durante as mais recentes ditaduras a fronteira ideológica se fez presente por meio das ocorrências no local, reverberada pela conjuntura repressiva transnacional tanto do ponto de vista das instituições estatais, quanto das relações entre os habitantes desse local. Assim, alguns pontos que se reportam ao aspecto de "identidade de fronteira" serão discutidos.

A fronteira é parte significativa da experiência dos habitantes locais; o modo como ela é vivenciada e narrada remete muito ao modo como cotidianamente se constrói distinção entre as nações. Nesse espaço, em especial, a nação se consolida com base na alteridade e na presença constante do outro, do diferente, do estrangeiro. As relações estabelecidas entre os habitantes de ambas as margens do Rio Uruguai são duais e denotam uma espécie de "jogo de interesses", principalmente na questão econômica, onde a conjuntura econômica do país

\footnotetext{
${ }^{155}$ DREXLER, Jorge. Frontera. In: Frontera. Virgin Records España, S.A. 1999.
} 
vizinho afeta o habitante do outro lado do rio, pois em determinadas circunstâncias a moeda brasileira está valorizada frente à moeda argentina, e em outras ocorre o contrário.

Mas, além disso, nota-se uma evidente cooperação entre alguns grupos dessas comunidades. Acerca da língua, ocorre uma integração substancial em ambos os países, favorecida pelo ensino de português em Paso de los Libres e de espanhol em Uruguaiana - em ambos os casos, o idioma vizinho é parte da grade curricular das escolas públicas. Ademais, a Lei 11.161/2005 tornou obrigatório o ensino de espanhol para os alunos do ensino médio no Brasil, ao mesmo tempo o Ministério da Educação do Brasil e o Ministerio de Educación, Ciencia y Tecnología da Argentina acordaram um projeto de escolas bilíngues de fronteira:

\footnotetext{
O Programa Escolas Bilíngües de Fronteira / PEBF nasceu da necessidade de estreitar laços de interculturalidade entre cidades vizinhas de países que fazem fronteira com o Brasil. A experiência dos primeiros anos a partir da sua efetiva implementação permite estabelecer uma discussão sobre os passos já dados e os que estão por vir. É objetivo deste documento, em versão preliminar, apresentar um pequeno histórico do Programa, uma rápida exposição de situações de fronteira e uma descrição do Modelo que vem sendo desenvolvido e seu funcionamento. ${ }^{156}$
}

Esse programa atua por meio do uso da língua, ensinada nas escolas. Um falante nativo da segunda língua participa desse processo: professores brasileiros atuam na cidade argentina vizinha, e professores argentinos atuam no Brasil. Além de fortalecer o ensino da língua, essa relação possibilita que fatores culturais do país limítrofe sejam vivenciados pelos estudantes e professores. Essa proposta aproxima os cidadãos fronteiriços para além de instrumentalizar uma nova língua.

O carnaval também é uma experiência de aproximação entre argentinos e brasileiros. Uruguaiana tem um dos carnavais mais concorridos do Rio Grande do Sul, e Paso de los Libres também possui uma festa carnavalesca reconhecida na Argentina. A integração é substancial, visto que as datas dos eventos são discutidas, para que não ocorram no mesmo período; sendo assim, além dos habitantes poderem prestigiar a festa em ambas cidades, as próprias agremiações carnavalescas fazem intercâmbio entre si, desfilando na cidade vizinha - isso também ocorre com o Uruguai - e ajudando na estrutura das agremiações e do desfile em si.

Qual a identidade da fronteira Uruguaiana-Paso de los Libres? As pesquisas acerca dessa fronteira apontam para uma zona de contato, de fronteirização, de vizinhança. Será feito contexto "sob medida" - não é objetivo destrinchar a identidade de fronteira desde a mais

\footnotetext{
156 Programa Bscolas Bilíngues de Fronteira. Disponível em: http://portal.mec.gov.br/seb/arquivos/pdf/Escolafronteiras/doc_final.pdf. Março/2008.
} 
remota pista, pois a Tese busca abordar a possível identidade vivenciada nos anos de exceção e nos quais o problema da Tese está inserido. Não é pretensão definir uma identidade para essas comunidades, mas sim tentar alcançar como se percebiam esses cidadãos enquanto fronteiriços (moradores ou de passagem). Nesse sentido, a identidade é abordada como percepção do eu e do outro.

A proximidade geográfica das duas cidades faz com que a população compartilhe não somente um território, mas, consequentemente, a construção cultural dos fronteiriços. $\mathrm{O}$ passeio no comércio da cidade vizinha, principalmente na Avenida Colón ${ }^{157}$ em Paso de los Libres, e Rua Duque de Caxias em Uruguaiana. As compras em supermercados argentinos e brasileiros, as músicas, enfim, um modo de vida presente no cotidiano dessas pessoas engendra um sentimento de pertencimento ao lugar, à região, à fronteira. É quando estas experiências materializadas e o sentimento deixam de pertencer a um ou a outro país, passando a pertencer aos fronteiriços.

Do ponto de vista econômico, as duas cidades têm sua produção basicamente calcada na agropecuária. Todavia, para a cidade argentina, o comércio tem acentuado papel na agenda econômica, diferente de Uruguaiana. A prática comercial entre os moradores dos dois países propicia uma interação e cria vínculos entre esses. Paso de los Libres é notadamente mais comercial, enquanto Uruguaiana tem um grande potencial agropecuário. A lógica econômica da região pouco se alterou com o processo de desenvolvimento. Tecnologias inovadoras são presentes, principalmente na agenda rural, porém não houve um processo de industrialização ou mudança significativa que pudesse trazer outros investimentos na área econômica.

A identidade é processo de construção de referenciais significativos com base em atributos culturais que se interseccionam. Na constituição da identidade pessoal ou social há uma dependência, segundo Goffman, "dos interesses e definições de outras pessoas em relação ao indivíduo cuja identidade está em questão"158. Com fundamento nesse autor, estudos sobre a identidade indicam que aquilo que o "outro" pensa a respeito do sujeito é fundamental no processo de identificação ${ }^{159}$. Como se observa na proposição de Mello, a

\footnotetext{
${ }^{157}$ A Avenida Colón é uma das mais importantes de Paso de los Libres, concentra um comércio significativo bem como bares e restaurantes. Lugar comumente frequentado por brasileiros aos finais de tarde, visto que o comércio brasileiro, em geral, encerra as atividades entre às $18 \mathrm{~h}$ e $19 \mathrm{~h}$ e o de Paso de los Libres entre $21 \mathrm{~h}$ e 22h. A Rua Duque de Caxias, em Uruguaiana, é que a concentra o maior número de lojas da cidade e comumente frequentada por argentinos.

${ }^{158}$ GOFFMAN, E. Estigma: notas sobre a manipulação da identidade deteriorada. 4. ed. Rio de Janeiro: Zahar, 1988. p. 116.

${ }^{159}$ STEINKE, Sabrina. Fronteira Brasil-Argentina, relações estabelecidas por meio de uma prisão clandestina.
} Revista Múltipla, a. XVII, v. 26, n. 34, p. 37, jun. 2013. 
identidade tem origem no outro, em como esse diferente nos define, elaboramos a identidade por meio de similitudes e semelhanças, igualdades e desigualdades. ${ }^{160}$

Dessa forma, o reconhecimento ${ }^{161}$ por parte do "outro" é elemento essencial para a construção da identidade, visto que o "eu" é uma construção de referências cruzadas, que se realiza entre indivíduos próximos que são significativos. No decorrer da vida do sujeito, os conteúdos e os raciocínios tendem a separar-se daqueles e daquelas que o emitiram; assim, Singly interpreta que: "[..] no interior da consciência, o indivíduo identifica-se não apenas com outros significativos mas também como uma generalidade de outros, isto é, com uma sociedade". ${ }^{162}$

Em face do exposto, compreende-se que há nexo entre o reconhecimento e a identidade, ou seja, ter uma identidade pressupõe não apenas o conhecimento próprio, mas também o reconhecimento alheio. Para manter sua auto identificação, o indivíduo precisa do outro. Nesse sentido, uma zona de fronteira é rica em relação a reconhecer a si e aos outros, e também proporciona uma identidade compartilhada quando se entende como fronteiriço. A vivência em um espaço de fronteira propicia que uma identidade seja construída com aspectos de ambos os países. Os sujeitos que ocupam esse espaço experimentam, no cotidiano, situações binacionais. A identidade de fronteira é ambígua, assim como a fronteira. A "separação" geográfica tem uma dimensão muito mais abrangente quando a reflexão se volta para as questões de convivência, reconhecimento e diferenciação. As leis, os costumes, a comida, a cultura são diferentes de um lado e de outro do rio. Ocorre uma interpenetração entre as identidades, que se sobrepõe ao modelo nacional. Um cidadão fronteiriço precisa aprender a compreender o outro, o diferente e, dessa forma, amplia o seu conjunto de fatores que constroem sua identidade.

As relações entre Argentina e Brasil, no campo político, podem ser tidas como conflituosas. A proximidade geográfica em determinadas ocasiões propõe que o vizinho é um potencial inimigo, que pode invadir seu território - desse modo, para os cidadãos da província de Corrientes o vizinho poderia atacar suas terras, assim como para os gaúchos. O espaço fronteiriço é um espaço de tensão. Para além do intercâmbio cotidiano e da construção da identidade fronteiriça como de encontro, na agenda política e de espaço, a fronteira é um local

\footnotetext{
${ }^{160}$ MELLO, S. L. A identidade uma tentativa de aproximação. In: Anais do I Encontro Interdisciplinar Sobre Identidade. São Paulo: Boletim do Grupo de Pesquisa sobre Identidade Social, 1983. p. 59.

161 Entende-se por reconhecimento da diversidade cultural a ação de valorização da diferença, seguida de sua naturalização. Ou seja, reconhecimento da diversidade cultural é a não-essencialização da diferença, visto que esta é marca distintiva e inerente à condição humana.

162 SINGly, F. O eu, o casal e a família. Trad. de Magda Bigotte Figueiredo. Lisboa: Publicações Dom Quixote, 2000.p.3.
} 
de conflito. Na fronteira Uruguaiana-Paso de los Libres essa dualidade é presente, integrada em aspectos habituais e de tensão no campo formal.

Essa condição dupla pode ser vivenciada no trâmite de ingresso aos países vizinhos, principalmente após a construção da ponte internacional. Com a travessia simplificada o controle foi intensificado, tornando muito mais difíceis de se executar atividades ilegais, por exemplo, bem como a burocracia para ingressar no país vizinho passou a ser aplicada com mais regularidade e intensidade.

É comum o trânsito de cidadãos das cidades desta fronteira em ambos os países, principalmente para comprar e atividades de lazer, episódios que ocorrem desde que a travessia era feita apenas por balsa. Nesse sentido, temos uma vivência de fronteira integrada, as "idas e vindas" ao país vizinho. Essas "idas e vindas", porém, ratificam que esse espaço é o que "separa" um país do outro, além da tensão intrínseca nas fronteiras representada pelo enorme contingente de policiais, servidores de diversas instituições de controle e militares. A fronteira que agrega e possibilita uma identidade compartilhada é também um espaço de controle.

Durante os anos de vigência de Estados ditatoriais é de se esperar, analisando uma fronteira entre países de relações, por vezes, estremecidas, práticas de proteção em relação ao outro, principalmente em um período de zelo mais rigoroso com a segurança nacional. Mas o que se percebe é que ocorreu uma intensa relação de vizinhança e de ajuda mútua entre esses diferentes.

As cooperações de solidariedade entre cidadãos fronteiriços foram praticadas movidas por afinidade ideológica, do mesmo modo que as conexões repressivas estabelecidas através do aparato estatal. Houve diversos casos que demonstram cooperação entre instituições de segurança brasileiras e argentinas agindo colaborativamente contra os "inimigos" - assim como há registros destes ditos "inimigos" cooperando entre si. Pode-se dizer que em alguns casos de exceção, determinados grupos transcendem seu suposto nacionalismo para proteger algo que consideram mais relevante no campo político, ou que, naquele momento e dentro de suas perspectivas, vai reverberar benefícios para um número mais significativo de pessoas e para si.

A fronteira Uruguaiana-Paso de los Libres é uma zona dinâmica, e uma de suas especificidades é a estruturação de sistemas cooperativos transnacionais de grupos aliados ideologicamente - de um lado, agentes públicos "defendendo-se dos inimigos" e de outro, os ditos "inimigos" lutando por liberdade e democracia. Portanto para compreender como a 
repressão no final dos anos 1970 ocorreu nesta região fronteiriça, é preciso entender como ela foi formada.

\subsection{Uruguaiana e Pasos de Los Libres}

Uruguaiana e Paso de los Libres foram fundadas e constituídas por meio de uma série de processos políticos e econômicos que remontam ao século XIX, ambas com características comuns presentes no cerne do surgimento dessas cidades: a logística comercial que o Rio Uruguai oferece; lutas dos governos locais/regionais com os poderes centrais; e alianças mútuas e expansão de território. ${ }^{163}$

Nesse ponto da Tese o objetivo é tratar dos processos de fundação de ambas as cidades, com intuito de compreender esses espaços em suas particularidades para entender as interações de fronteira ocorridas no período estudado.

\subsubsection{Como é longe Uruguaiana}

[...] não te preocupa bagual, que campeiro não se engana, quem segue o rastro do sol, sempre chega a Uruguaiana. ${ }^{164}$

“Como é longe Uruguaiana" Aires, está localizada na fronteira oeste do Rio Grande do Sul. Uruguaiana possui uma população de 130.000 habitantes, segundo o último Censo do Instituto Brasileiro de Geografia e Estatística $(\mathrm{IBGE})^{166}$. Conforme informação da Prefeitura Municipal, é o quarto maior município do Rio Grande do Sul e o maior porto seco da América Latina - por Uruguaiana ingressam anualmente mais de 100.000 turistas em território brasileiro. ${ }^{167} \mathrm{~A}$ economia da cidade e região é calcada no agronegócio, sendo destaque a produção de arroz, criação de ovelhas e cavalos crioulos, atividades que não necessitam de um número expressivo de funcionários. Essa peculiaridade na produção é um dos fatores para a desigualdade social

\footnotetext{
163 GRIMSON, A. La nación en sus límites - Contrabandistas y exilados en la frontera Argentina-Brasil. Barcelona: Editorial Gedisa S/A, 2003. p. 64.

${ }^{164}$ LEITE, João Chagas; DUARDE, Vaine. Por quem cantam os cardeais. In: Por quem cantam os cardeais. ACIT Discos. 1985. Lado A, cancão 1.

${ }^{165}$ Expressão muito utilizada no Rio Grande do Sul, em geral quando de uma viagem para a cidade, partindo da capital do Estado - Porto Alegre. Faz referência ao tempo de viagem em torno de nove horas de ônibus, e da paisagem da campanha que dá impressão de que "não se saí do lugar".

${ }^{166}$ Em 2010 a população era de 125. 435 habitantes e a estimativa para 2014 de 129.580. Fonte IBGE disponível em: http://cidades.ibge.gov.br/xtras/perfil.php?lang=\&codmun=432240 acesso em 14 de setembro de 2014 às $14 \mathrm{~h}$.

${ }^{167}$ Dados disponíveis em: http://www.uruguaiana.rs.gov.br Acesso em 12 de agosto de 2014 às $11 \mathrm{~h} 44 \mathrm{~min}$.
} 
característica da região, visto que o setor de comércio não atende a demanda da população quanto ao número de empregos existentes. O transporte é a atividade com maior fluxo financeiro da cidade, mas, assim como o comércio, não atende diretamente a população local. Uma das características importantes de Uruguaiana é sua localização: próxima de Buenos Aires, Porto Alegre e Montevideo.

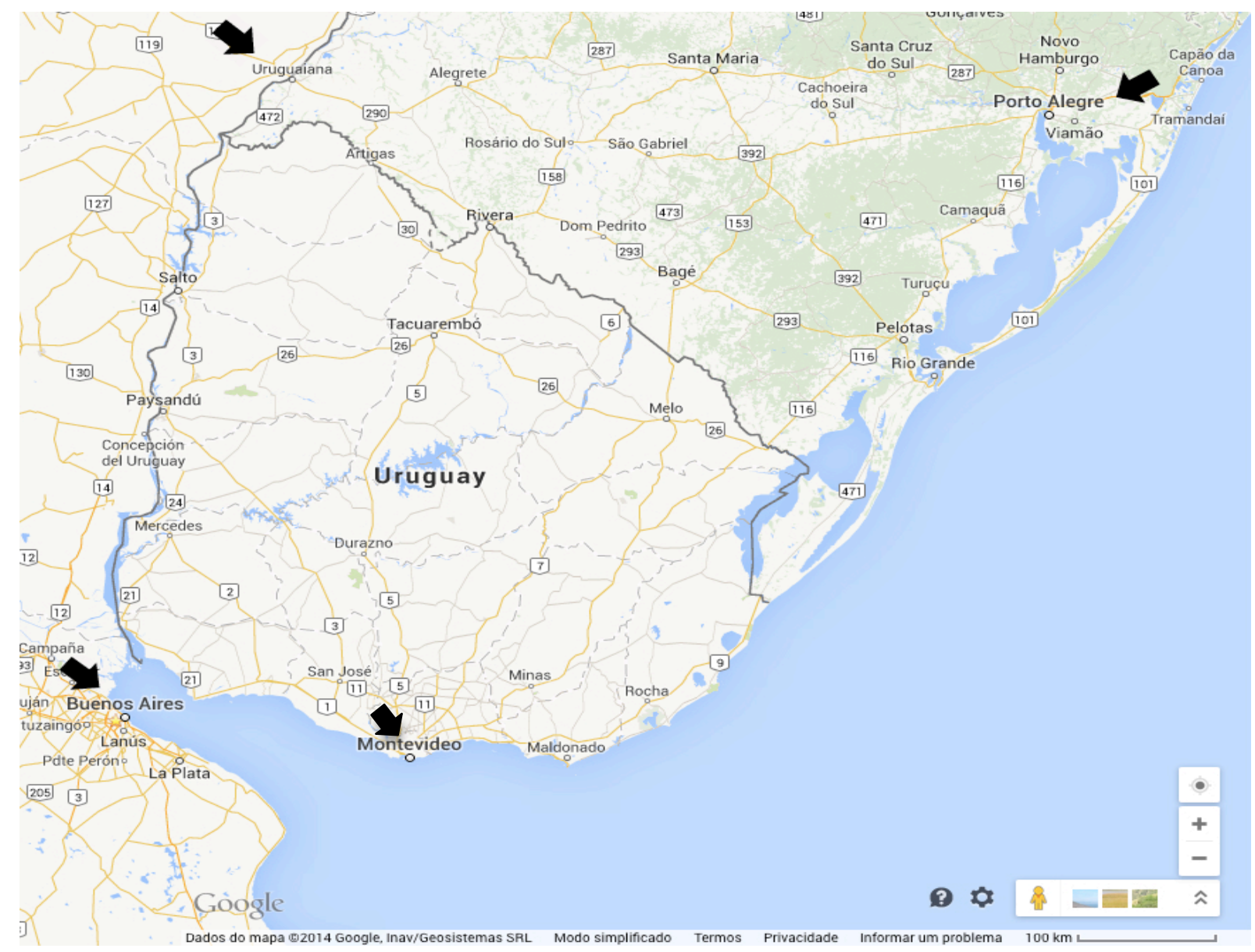

Figura 2 - Mapa demonstrativo acerca das distâncias de Uruguaiana até as capitais de Argentina e Uruguai, e da capital do Rio Grande do Sul - Porto Alegre.

Fonte: Adaptado de Google Maps (2014).

\section{A formação de Uruguaiana se origina das disputas entre as coroas Portuguesa e} Espanhola no século XVIII. Esta região foi de sesmarias ${ }^{168}$, o que ajuda explicar a conjuntura

${ }^{168}$ Diante da crise agrícola que acometeu a Europa, Portugal criou a Lei das Sesmarias em 1375. Objetivava manter o campo povoado, e dava certa autonomia aos que viviam da agricultura. Durante a colonização utilizou essa agenda, com ajustes, no Brasil a sesmaria passava a ser uma propiedade que foi cedida para o "sesmeiro". A distribuição de terras na colônia tinha intuito de povoar. Uma sesmaria tinha em media 13.000 hectares, mas isso era muito variável. Em alguns casos o "sesmeiro" podia ser agraciado com mais de uma sesmaria, ou com um território muito maior que outros. Conforme Costa: "Na década de 1730, fora dado início à doação de sesmarias na região abaixo do rio Mampituba, como forma de garantir as terras para Portugal por meio do uti possidetis, que fazia parte dos novos aportes postos em voga pelo direito natural 
econômica baseada, principalmente, no agronegócio, os grandes latifúndios e a prática do coronelismo $^{169}$ predominante na região.

Nas margens do Rio Uruguai, no começo do século XIX, uma localidade chamada Santana Velha se formou com intuito de cobrar impostos dos comerciantes que atravessavam mercadorias entre as margens do rio - posteriormente Uruguaiana e Paso de los Libres. Para executar essa cobrança, tentar minimizar o contrabando e garantir segurança para o território, esse local contava com um posto fiscal, acampamento militar e poucos moradores - em geral, as famílias de quem trabalhava nessas atividades.

Em 1840 uma inundação destruiu essa localidade. ${ }^{170} \mathrm{~A}$ região, por ser estratégica, precisava ser "povoada" novamente, e o governo do Rio Grande do Sul, à época independente do Brasil devido a Revolução Farroupilha ${ }^{171}$, criou um vilarejo nas redondezas da vila de Santana Velha - foi a única localidade fundada pelos farrapos. Em 1846, após o fim da Guerra dos Farrapos, o então governo provincial elevou essa localidade para a categoria de vila, que em 1874 se tornou cidade. A posição estratégica de Uruguaiana, motivo de sua fundação, é também o que acarretou a série de conflitos no local durante toda sua formação. E mesmo em "tempos de paz", a proximidade com a Argentina faz com que crimes como o contrabando sejam praticados até os dias atuais - é uma região conturbada em sua essência.

moderno. Assim, tentava-se garantir uma fronteira que se tornasse cada vez mais concreta para um espaço até então de penetração multifacetada". Cf. COSTA, Alex Jacques. Seguindo ordens, cruzando campos: o governador e capitão general Dom Diogo de Souza e a política do Império Português para o Rio da Prata (1808 - 1811). Dissertação de mestrado. Pontifícia Universidade Católica do Rio Grande do Sul - PUCRS. Porto Alegre, 2010. p. 47. Cf. GARCIA, Graciela Bonassa. O domínio da terra: conflitos e estrutura agrária na campanha rio- grandense oitocentista. Dissertação de Mestrado - UFRGS, Porto Alegre, 2005. Cf. COLVERO, Ronaldo Bernardino; SOARES, Luiz Francisco Matias. Uruguaiana: a estância como fronteira. Estudios históricos - CDHRP, n. 3, dez. 2009.

${ }^{169}$ Não se afirma que "sesmarias" e "coronelismo" são um processo conjunto, o intuito é pautar o coronelismo que é um fenômeno típico da Primeira República (1889-1930) - vivenciado na região de Uruguaiana, como uma herança das sesmarias, pois foi nesta ocasião que surgiram os grandes proprietários de terra. Entende-se o coronelismo como propõe Leal, que aponta os coronéis como uma amálgama de senhor de terras e administrador municipal, a relevância do coronel dependia da quantidade de votos que esse podia conseguir, e a influência de um coronel em sua sociedade em muito se deve a quantidade de terras que possui. Cf. LEAL, Vitor Nunes. Coronelismo, enxada e voto. São Paulo: Editora Alfa-Omega, 1976. Cf. FAORO, Raymundo. Os donos do poder. São Paulo: Editora Globo/EDUSP, 1975. v. 2.

170 COLVERO, Ronaldo Bernardino; SOARES, Luiz Francisco Matias. Uruguaiana: a estância como fronteira. Estudios históricos - CDHRP, n. 3, dez. 2009.

${ }^{171}$ Geralmente, a Revolução Farroupilha é a forma como se insere o Rio Grande do Sul nas aulas de História do Brasil, sem dúvida, o processo histórico mais "famoso" e difundido do Estado. Uma guerra promovida pelos estancieiros gaúchos que não estavam satisfeitos com a política imperial, particularmente, sentiam-se prejudicados com a taxação do charque. Entraram em confronto com o Império, conflito que durou 10 anos de 1835 à 1845. E terminou com um acordo, o Tratado de Poncho Verde, entre estancieiros e Império. Cf. PESAVENTO, Sandra. A Revolução Farroupilha. São Paulo: Brasiliense, 1985. 


\title{
3.2.2 Paso de los Libres: a passagem dos 108
}

\begin{abstract}
El pueblo está assentado sobre una colina cuyas pendientes en todas direcciones presentan un aspecto extraordinario de singular belleza, por la alfombra de vegetación que la circunda. La parte densa de la ciudad ocupa la cumbre de la cuchilla, elevándose majestuosa sobre el río Uruguay como si mirasse desde su trono de esmeralda a su vecina, la coqueta y hermosa Uruguayana, a través del espejo del soberbio estuário donde se retratan sus encantos impoderables [...]. ${ }^{172}$
\end{abstract}

Paso de los Libres não difere tanto, nos aspectos de sua formação, aos de Uruguaiana. As margens do Rio Uruguai, em 1843, foi criado o "Puerto de Paso de los Libres", um povoado erigido com objetivo comercial. Esse povoado, além de incentivar o comércio, foi construído também por motivo político, pois incitar o comércio com Brasil e Uruguai era uma das táticas “anti Rosas". Nesse período, os irmãos Madariaga estavam empenhados em tirar Juan Manuel de Rosas do poder ${ }^{173}$. Chegaram a se exilar no Brasil, no caso em Alegrete, à época capital da Revolução Farroupilha, e em São Borja. ${ }^{174}$ "En marzo de 1843 poco más de cien hombres cruzaron el Uruguay una legua al sur de Uruguayana. Un mes después, los Madariaga lograron derrocar al gobierno de Corrientes y desde el gobierno provincial el 12 de septiembre de 1843". ${ }^{175}$ Desde então, se rememora a passagem dos 108 libertadores, na data de fundação de Paso de los Libres. "Fue estancia jesuítica, "Rincón” lugar apropriado para guardar la hacienda, atesorando el Avá-Ñeé, hermanándonos con lazos particulares al Río Grande do Sul. Nació como expresión de libertad durante la guerra que envolvió a la Confederación Argentina. ". 176

Paso de los Libres, como aponta seu nome, é tida como "passo", local de passagem/cruze ${ }^{177}$; sua economia é voltada ao comércio, que é fomentado pela localização fronteiriça. Tem em torno de 50 mil habitantes. A oscilação da moeda, das importações e exportações fez com que a cidade tenha vivenciado experiências de forte desenvolvimento

${ }^{172}$ RUBIO, Gladis Dora Mango; AGUIRRE, Delia Antonia Guadalupe. Paso de los Libres: história, espacio y memoria. 1. ed. Corrientes: Moglia Ediciones, 2007.

${ }^{173}$ Desde 1835, quando Rosas assumiu pela segunda vez o governo de Buenos Aires, as relações com a província de Corrientes (Santa Fe e Entre Ríos, também não concordavam com a política de Rosas) não eram amigáveis. O governador de Santa Fe, Estanislao López atuava como um "apaziguador", após sua morte o rompimento de Corrientes com Rosas foi inevitável, assim como a batalha. Em 1839 correntinos foram vencidos na batalha de Pago Largo. Um grupo encontrou guarida no Rio Grande do Sul, entre eles estavam Juan e Joaquín Madariaga, Joaquín foi designado Comandante en Jefe de la División Libertadora do Cuarto Ejército Libertador. Que venceu as forças de Rosas em Corrientes. Cf. RUBIO, G. Paso de los Libres: una reivindicación a la libertad. In: RUBIO; AGUIRRE, op. cit., p. 37-41.

174 PELLEGRINI, Enrique. Paso de los Libres: crónicas y ensayos. Buenos Aires: López Libreros. p. 32-33.

${ }^{175}$ GRIMSON, A. La nación en sus límites - Contrabandistas y exilados en la frontera Argentina-Brasil. Barcelona: Editorial Gedisa S/A, 2003. p. 65.

${ }^{176}$ RUBIO, G.; GUADALUPE, D. La singularidade del Paso. In.: RUBIO; AGUIRRE, op. cit., p. 23.

177 A palavra "cruze" é utilizada na tese no sentido de atravessar, passar. É muito utilizada em regiões de fronteira. 
econômico e também graves crises. Paso de los Libres faz parte da província de Corrientes, que tem como base econômica a pecuária. Porém, diferente de Uruguaiana, Paso de los Libres não é uma cidade que tem sua economia baseada no agronegócio ou em latifúndios. O cultivo de arroz começou por volta de 1905, e não é uma atividade que se diferencie na economia local, como ocorre em Uruguaiana. É, e sempre foi, calcada no comércio internacional. Conforme Aguirre:

El intercambio oficial fue fluido desde el asentamiento del Pueblo, pero los primeros registros hallados sobre tráfico fronterizo fluvial datan de 1848 y fueron realizados por la Receptoría de Rentas, organismo que tenía a su cargo la recaudación por tasas a la introducción de mercaderías. [...] Revistio la categoria de Puerto de Segunda, el entonces Pueblo de Restauración, a partir de junio de 1854 y dependia de la Aduana de Corrientes. Dicha categoria significaba habilitación oficial para el comercio exterior. ${ }^{178}$

O transporte de passageiros, mercadorias e correspondência se intensificou em 1864 com a Ley Nacional $n^{\circ}$ 90, que tratava da navegação no Alto Uruguai, criando uma linha de navegação conhecida como "carrera del Alto Uruguay" - entre os portos de trânsito estava o de Paso de los Libres. Em 1877, foi fundada a primeira empresa de transporte fluvial da localidade. O desenvolvimento da economia levou que a ferrovia chegasse até o porto em 1894, ao mesmo tempo em que grandes depósitos foram construídos. Assim, Paso de los Libres foi se constituindo em função do porto. O comércio internacional e o tráfico fluvial foram os motores que impulsionaram o processo econômico e político da cidade. $\mathrm{O}$ tráfego de pessoas era feito por embarcações regulamentadas pela Marina Mercante. "Entre Paso de los Libres y Uruguayana el movimiento comercial diário [em 1893] era intenso, realizándose viajes con pasajeros y carga cada hora, repartidos entre 7 lanchas argentinas y 7 brasileñas". ${ }^{179}$

\subsubsection{A ponte internacional}

A construção da ponte ligando Brasil e Argentina foi sem dúvida um marco no que tange o câmbio de relações estabelecidas nessa fronteira - uma mudança que engloba todos os aspectos das sociedades envolvidas. Antes da construção da ponte, a travessia se realizava por meio de embarcações de pequeno porte com capacidade para até 20 pessoas.

\footnotetext{
${ }^{178}$ AGUIRRE, D. Cuando en Paso de los Libres había Puerto. In.: RUBIO, Gladis Dora Mango; AGUIRRE, Delia Antonia Guadalupe. Paso de los Libres: história, espacio y memoria. 1. ed. Corrientes: Moglia Ediciones, 2007. p. 79.

${ }^{179}$ Ibidem, p. 77-84.
} 
Conforme o acervo do Centro Cultural de Uruguaiana Dr. Pedro Marini, a construção da ponte se estendeu de 1940 a 1945, e sua inauguração oficial foi em 1947. A ponte tem dois nomes, um no lado brasileiro e outro no argentino: Ponte Internacional Presidente Getúlio Vargas e Ponte Internacional Presidente Agustín Justo, nomeadas em referência aos presidentes que firmaram o acordo de construção da ponte. Foi inaugurada oficialmente em 21 de maio de 1947 pelos presidentes Juan Domingo Perón, da Argentina, e Eurico Gaspar Dutra, do Brasil, embora estivesse aberta ao trânsito desde 12 de outubro de $1945{ }^{180}$

As negociações e mesmo a construção em si da ponte não foram o que se pode chamar de processo tranquilo; havia tensão entre os governos, e tensões internas de cada país envolvido. Conforme Dávila, no lado brasileiro o ponto de inflexão se dava entre as forças armadas e o governo - a autora aponta que o exército tentou postergar ao máximo a efetivação dessa obra, pois temia um ataque argentino, que seria facilitado devido a travessia pela ponte. Atrasar a construção daria tempo para que a instituição militar se preparasse melhor para defender o território brasileiro de ataques surpresas. Uma corrente do Exército trabalhava com a hipótese de uma invasão surpresa da Argentina. ${ }^{181}$

A região não estava preparada militarmente para conter uma incursão do país vizinho, seria preciso buscar reforços. Como Uruguaiana estava distante demais dos grandes centros e a comunicação na época não era fácil, até que o exército pudesse reagir, a cidade já estaria dominada. Dávila argumenta que esse receio se dava pelo aumento de arsenal e preparação do Exército argentino, bem como nos retrocessos nos acordos diplomáticos durante a fase de pesquisa para a construção da ponte, época em que o projeto permanecia estagnado. ${ }^{182}$

Outro acontecimento que influenciou o atraso nas obras foi a Segunda Guerra Mundial, já que as posições governamentais de Brasil e Argentina não eram as mesmas. O governo argentino, dizendo-se neutro, isolava-se no contexto americano, enquanto o brasileiro estava articulado com os Estados Unidos. Quando o Brasil declarou guerra contra a Alemanha, o Exército brasileiro passou a patrulhar intensamente a fronteira com a Argentina. Apesar das tensões, em 1943 - cinco anos depois da inauguração dos monolitos -, a construção da ponte foi iniciada, sendo finalizada em $1945 .{ }^{183}$ Os monolitos foram

\footnotetext{
${ }^{180}$ Acervo sobre a Ponte Internacional Presidente Justo e Presidente Vargas, Centro Cultural de Uruguaiana Dr. Pedro Marini. Pasta com material sem paginação. Ver mais informações em: http://www.radiolt12.com.ar/vernota.asp?id_noticia=56367 acesso em 13 de janeiro de 2014 às $17 \mathrm{~h}$.

${ }^{181}$ DÁ VILA, Maria de Lourdes Brondani. A ponte internacional Brasil-Argentina: limites e possibilidades da política de boa vizinhança. Dissertação de Mestrado. Pós-Graduação em História. IFCH Pontifícia Universidade Católica do Rio Grande do Sul. PUCRS. Porto Alegre, 1994.

${ }^{182}$ Ibidem.

${ }^{183}$ GRIMSON, A. La nación en sus límites - Contrabandistas y exilados en la frontera Argentina-Brasil. Barcelona: Editorial Gedisa S/A, 2003. p. 93.
} 
inaugurados em 9 de janeiro de 1938 e contaram com a participação dos presidentes Getúlio Vargas do Brasil e de Agustín Justo da Argentina.

Segundo o Ministério dos Transportes, a construção da ponte foi viabilizada pois o transporte por meio de balsas dificultava o intercâmbio - as características do Rio Uruguai (caudaloso em período de chuvas e com nível de água muito baixo na seca) complicavam a logística do transporte fluvial, tanto para o transbordo de pessoas como para o de mercadorias, o que acarretava em longas esperas e prejuízos. Ainda conforme o Ministério dos Transportes, esses problemas teriam sensibilizado os governantes de ambos os países, após inúmeros pedidos de moradores da região.

Para a realização da travessia havia três alternativas: Uruguaiana-Paso de los Libres; Itaqui-Alvear e São Borja-Santo Tomé. Em 1934 e 1935 foram assinados dois tratados, um em Buenos Aires e outro no Rio de Janeiro. Uma equipe foi designada para os trâmites da obra, chamada Comissão Mista Brasileira-Argentina, com intuito de realizar estudos e escolher o ponto de travessia. A região de Uruguaiana foi eleita, levando em conta características topográficas e hidrográficas. A pesquisa apontou que havia uma distância mínima de 1.200 metros entre as duas margens, mas devido à condição dos terrenos não poderia ser aproveitada.

Os trechos em que as margens eram distantes demais também foram excluídos (em geral com mais de 2.000 metros), bem como os com grande profundidade do leito. ${ }^{184}$ Dessa forma, Uruguaiana-Paso de los Libres foi a localização mais adequada, conforme os laudos técnicos, para a construção da ponte.

Após os acordos firmados, cada país ficou responsável pela construção de $50 \%$ da ponte, o que fez com que ocorressem duas licitações diferentes para a execução da obra. No Brasil, a coordenação e supervisão do trabalho foi de uma Comissão Construtora, dirigida pelo engenheiro Oscar Machado da Costa auxiliado por José Mauricio da Justa. A empresa responsável foi a empreiteira Matheus Martins Noronha \& Cia. ${ }^{185}$ As concorrências aconteceram ao mesmo tempo nos dois países. Na Argentina:

A construção do lado argentino foi confiada à Administración General de Ferrocarriles del Estado em colaboração com a empresa construtora Parodi y Figini e se estendeu de fins de 1942 a princípios de 1945, em plena época de guerra

\footnotetext{
184 Fonte: Ministério dos Transportes. Disponível em: http://www2.transportes.gov.br/bit/02-rodo/9-pontesviadutos/pontes/pt_divisa/br_arg_uruguaiana/GPTARGBR.HTM Acesso em 20/04/2014 às 14h.

${ }^{185}$ Brasil. Diário Oficial da União. Seção I. 25 de setembro de 1944. p. 32.
} 
mundial. As obras foram terminadas em 1945 pela Administración General de Vialidad Nacional sob a direção de Eng. Roberto Maffía. ${ }^{186}$

A abertura da ponte ocorreu dois anos antes de sua inauguração oficial, segundo Pellegrini, devido à tensão diplomática entre os países; a população local das duas margens, entretanto, comemorou a abertura, bem como dois anos depois participou da grande festa de inauguração. ${ }^{187}$ Ainda segundo esse autor, a ponte passou a ser o tema mais difundido na região:

El tema puente estaba en todas las conversaciones, era el centro del pensamiento comercial, social, turístico y deportivo: 'Te espero del otro lado'; 'Nos encontramos en la cabecera'; ‘Pasaste?'; ‘Como te fue?; 'Lo habian cerrado'; 'Hay conflicto'; y otras expresiones semejantes que siempre connotaban su nombre sin decirlo. ${ }^{188}$

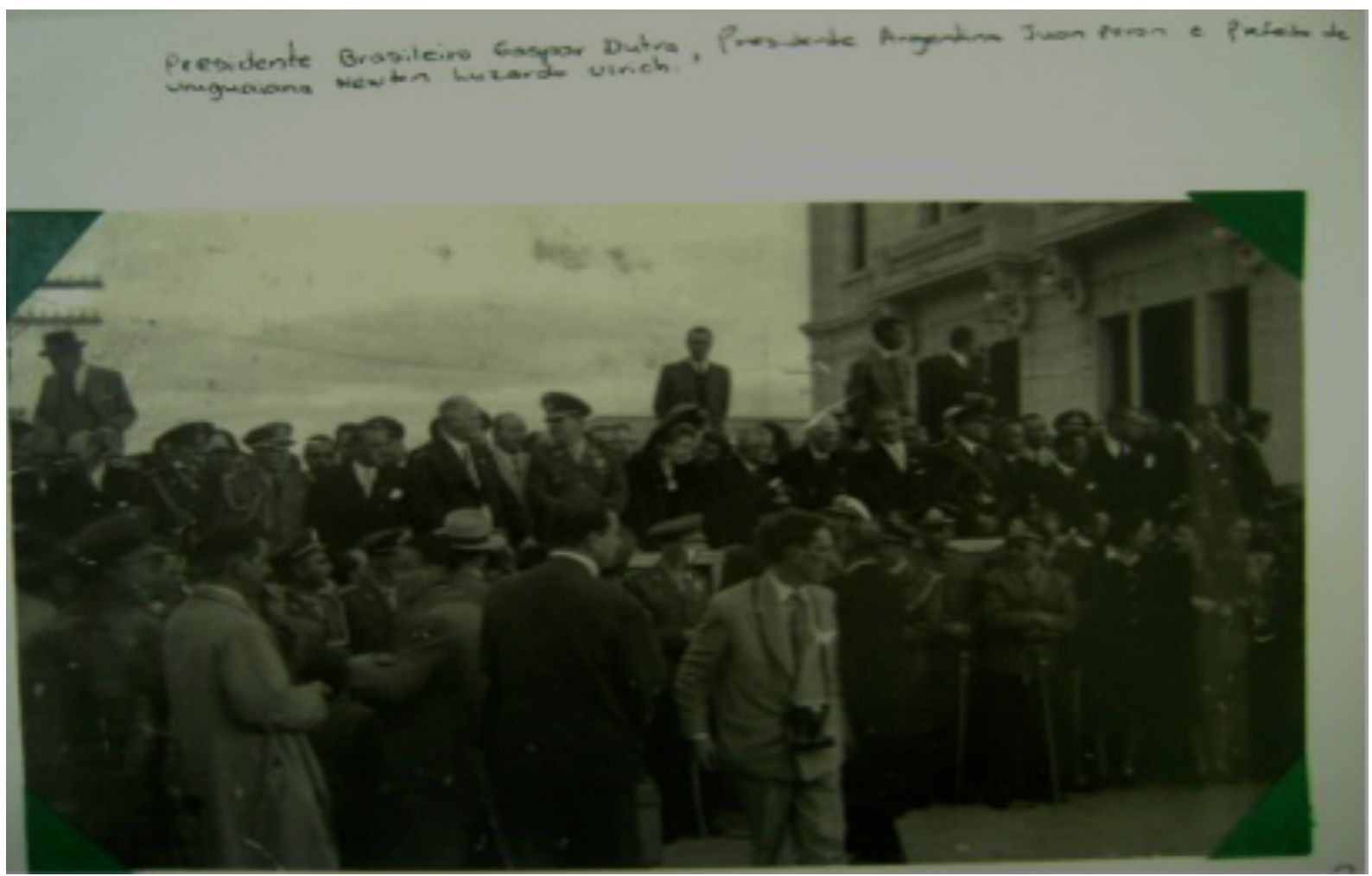

Figura 3 - Imagem da inauguração da ponte em 21 de maio de 1947.

Fonte: Acervo Centro Cultural Dr. Pedro Marini, Uruguaiana, Rio Grande do Sul (1947).

186 Fonte: Ministério dos Transportes. Disponível em: http://www2.transportes.gov.br/bit/02-rodo/9-pontesviadutos/pontes/pt_divisa/br_arg_uruguaiana/GPTARGBR.HTM Acesso em 20/04/2014 às 14h.

${ }^{187}$ PELLEGRINI, Enrique. Paso de los Libres: crónicas y ensayos. Buenos Aires: López Libreros. 1974. p. 138.

${ }^{188}$ Ibidem, p. 138-139. 
O jornal Correio do Povo, na seção chamada "Há um século do Correio do Povo", disponibiliza a transcrição de uma reportagem sobre a inauguração da ponte feita pelo enviado especial Abdias Silva:

\begin{abstract}
Uruguaiana e Libres estão vivendo momentos de grande significação na história americana. A inauguração oficial da ponte chamou a atenção de todo o hemisfério ocidental, sendo prova bastante e expressiva o grande número de representantes da imprensa de diversos países que aqui se encontram. A cidade viveu até ontem em relativa calma. Hoje, entretanto, o seu aspecto é completamente outro, bastando dizer que há nada menos de cinquenta aviões pousados aqui. As acomodações nos hotéis e casas de família foram completamente exgotadas. A caravana de jornalistas cariocas, para os quais lamentavelmente não havia sido feita a reserva de cômodos, desembarcou nesta cidade inteiramente sem rumo, enquanto se providenciava de qualquer jeito a sua distribuição. O movimento nas ruas principais é intenso, os cafés regorgitam e em meio ao povo estão as mais altas autoridades do país. No caso dêste batismo, entretando, não é a afilhada que centraliza propriamente a atenção, mas os dois padrinhos que amanhã se encontrarão para o importante ato público a ter como cenário o rio Uruguai, o qual, neste momento transborda as suas águas, principalmente no lado argentino, mais baixo. Um dêsses padrinhos, o general Eurico Dutra, chegou hoje a esta cidade e o outro, o general Perón, chegará amanhã. O cerimonial da inauguração é o mais simbólico possível, estando tudo preparado à base da confraternização argentino-brasileira. O povo aguarda, contudo, com o mais justificado interesse, que os dois presidentes discutam o problema vital dos interesses da Argentina e do Brasil: o do seu intercambio comercial. Nada transpirou até o momento sobre os assuntos concretos que serão discutidos nas conversações Dutra-Perón, reinando enorme expectativa em tôrno do histórico encontro. E não há como negar, que se nada ficar assentado no sentido de resolver o importante problema, o colorido dos cartazes anunciando brasileiros e argentinos como 'hermanos', não terá passado de ficção. ${ }^{189}$
\end{abstract}

As relações fronteiriças entre Uruguaiana e Paso de los Libres certamente sofreram um câmbio considerável a partir da inauguração da ponte internacional. A ponte foi um grande facilitador das relações sociais entre os cidadãos dessa região, ao mesmo tempo que reconfigurou a economia local, em ambas margens do Rio Uruguai. Conforme Grimson: " $E l$ puente le ha outorgado a la zona de Paso de los Libres - Uruguayana una gran peculiaridade en la amplia y heterogénea frontera argentino-brasileña". ${ }^{190} \mathrm{O}$ conceito de fronteira e as peculiaridades dela em Uruguaiana-Paso de los Libres, úteis para compreender a repressão política na região, são apresentados no próximo item.

\footnotetext{
189 "Hermanos" por Abdias Silva. Jornal Correio do Povo, quarta-feira, 21 de maio de 1947. Disponível em: http://www.cpovo.net/jornal/A114/N236/HTML/Seculo.htm acesso em 12 de janeiro de 2014 às $9 \mathrm{~h}$.

${ }^{190}$ GRIMSON, A. La nación en sus límites - Contrabandistas y exilados en la frontera Argentina-Brasil. Barcelona: Editorial Gedisa S/A, 2003. p. 17.
} 


\subsection{Fronteira, fronteirização, fronteira manejada, fronteira ideológica}

O tema desta Tese demanda uma reflexão sobre o conceito de fronteira, considerandoa além de um lugar físico, um locus de intercâmbio de experiências individuais, de contatos institucionais e de colaboraçãoo repressivas. As especificidades das experiências analisadas aqui estão diretamente ligadas ao espaço fronteiriço. Dessa forma, é necessário explicitar como a fronteira é percebida nesta pesquisa.

A fronteira é um limite geográfico; na concepção clássica da geografia política e, particularmente, da geopolítica, a noção de fronteira está associada às "estruturas espaciais elementares, de forma linear que correspondem ao invólucro contínuo de um conjunto espacial e, mais especificamente, de um Estado-Nação" ${ }^{\text {191 }}$. Restringida à escala nacional e privilegiando suas funções demarcatórias, reais e simbólicas, a fronteira designa normalmente uma descontinuidade política, o limite jurídico da soberania e da competência territorial de um Estado ${ }^{192}$.

Importante ressaltar a relação do termo fronteira com limites de zonas de povoamento. Segundo Gottmann ${ }^{193}$, a maioria das línguas tem uma palavra que caracteriza as populações situadas ao longo do "limite", existindo uma diferenciação para essas pessoas: características, direitos específicos ${ }^{194}$, significando que em diversas línguas a fronteira tem conotação de zona povoada e não de linha geométrica.

Fronteiras são, além de limites territoriais, separação entre nações, algo que nos parece tão familiar, tributárias de processos que remetem à Renascença europeia, por meio do desenvolvimento da cartografia, centralização de burocracias de reinos europeus que foram provocando um câmbio de escala acerca da representação, entraves para a circulação e exercício de autoridade que até então vivenciava-se na grande escala e se incorporam em

\footnotetext{
${ }^{191}$ FOUCHER, M. (1988). Fronts et frontières - Un tour du monde géopolitique. Paris: Fayard. 1991.

192 BRUNET, R. (Org.) Les mots de la Géographie - Dictionnaire critique. Montpellier-Paris, RECLUS.

193 GOTTMANN, J. (1973). The significance of territory. Charlottesville: University Press of Virginia. 1992. p. 134.

${ }^{194}$ Um exemplo atual é a "carteira de transfronteiriço" que os habitantes de Uruguaiana e Paso de los Libres tem direito, é uma identificação transnacional, permitindo que os cidadãos dessas cidades possam usufruir da saúde pública de ambas cidades vizinhas, trabalhar, bem como, facilitar o trâmite de aduana para circular entre as duas cidades, quem não reside em Uruguaiana ou Paso de los Libres, ou reside e não tem a carteira de transfronteiriço tem de fazer migração na aduana, o que até 2014 era desnecessário caso o destino fosse apenas a cidade de Paso de los Libres ou Uruguaiana.
} 
pequena escala, nas práticas de populações limítrofes. ${ }^{195}$ Ou como aponta Raffestin: "uma representação vaga para uma representação clara"196.

Com a instrumentalização por meio de mapas (em crescente produção), a demarcação de limites lineares e contínuos entre os reinos foi progressiva, concorrendo para a centralização do poder monárquico, já que permitia gerir e organizar um território que passa a ser percebido - no âmbito interno - como uno (no sentido de compreender um conjunto de regras ou leis para todo esse território demarcado). Também, de certa forma, era visto como homogêneo ${ }^{197}$. Paulatinamente, com o surgimento e a consolidação dos Estados Nacionais, as funções de controle legal, fiscal e militar - defesa do território - agregam uma característica de atuação, também, como filtro de fluxo internacional. Regrados pelos sistemas jurídicos internos, que por sua vez regulam as práticas aduaneiras, em especial de migração, sanitárias e comerciais.

A fronteira, enquanto limite de um Estado é o seu início e também seu fim, é um objeto geopolítico. Esse limite internacional, depois de instituído, é uma convenção, que foi ratificada e reconhecida por acordos diplomáticos; a área abarcada é um complexo conjunto de instituições e normas que visam regulamentar as atividades da sociedade que desse Estado faz parte ${ }^{198}$.

Percebe-se que o conceito de fronteira enquanto limite jurídico tem uma construção muito forte. Esse caráter de soberania e competência territorial de um Estado, no entanto, enfatiza processos e ações que são de cunho separativo - no longo prazo, isso encaminha para uma diferenciação do que podemos chamar de conjuntos espaciais envolvidos nas zonas limítrofes. São, porém, sistemas contíguos, separados juridicamente, mas unificados por uma série de fatores concretos (vegetação, clima) e abstratos (comunicação, contatos que se estabelecem). Nesse sentido, já podemos perceber que a fronteira é, para além de limite jurídico e estático, uma zona de transição, de intercâmbio e hibridização. Podemos, inclusive, agregar a característica de interface, ou seja, comunidades com características distintas mas com pontos em comum. A fronteira é uma zona de disputa, seja ela política, territorial ou cultural, onde os Estados se impõem - é o encontro do "eu” com o "outro".

\footnotetext{
${ }^{195}$ FOUCHER, M. (1988). Fronts et frontières - Un tour du monde géopolitique. Paris: Fayard. 1991. p. 81.

${ }^{196}$ RAFFESTIN, C. (1980). O território e o poder. In: Por uma geografia do poder. São Paulo: Ática, 1993. p. 169.

${ }^{197}$ Cf. FOUCHER, op. cit. Cf. RAFFESTIN, op.cit.

${ }^{198}$ RAFFESTIN, op. cit.
} 
Clássico dos estudos de fronteira, Turner ${ }^{199}$ propõe uma fronteira enquanto processo, não apenas um limite fixado; oferece para a fronteira o sentido de nascimento, um ponto de encontro entre civilizados e bárbaros, visto que o autor trata da expansão americana. Turner oferece "movimento" para a região de fronteira ${ }^{200}$. Esse "movimento" de Turner interessa a essa Tese, no sentido de avanço - não um avanço territorial, mas avanço de trocas entre fronteiriços, avanço enquanto ampliação cultural. Como explicitado por Thompson Flores: "O homem da fronteira não desconhece sua referência original, mas estabelece sua vivência considerando a existência da fronteira em si e as possibilidades que ela coloca em ambos os lados"201. O homem fronteiriço pertence ao seu Estado de nascimento, e ao mesmo tempo pertence ao espaço de fronteira, vivenciando trocas, compartilhando cultura, compreendendo o "outro", ou seja, a lógica e valores do cidadão do país vizinho. Em muitos casos ele incorpora valores do "outro" em seu cotidiano, mantendo porém seus referenciais de origem.

Para Castello ${ }^{202}$, fronteira se constitui em um espaço dual, de separação e trocas. Limites se estabelecem entre os Estados, ao mesmo tempo que ocorrem cruzamentos devido a proximidade física e interesses comuns. Em uma perspectiva clássica e/ou tradicional, pode-se pensar fronteira como uma região defensiva, fechada, com a atenção voltada para dentro.

Dissociar fronteira de separação e/ou segurança não é tarefa fácil, e nem intuito, já que a priori uma fronteira é um limite, que indica fim - ou começo; é onde um Estado começa que o outro termina, separa "nós" do "outro", ou seja, a fronteira é um limite que tem como um dos objetivos separar. Para este trabalho interessa trabalhar essa fronteira na dimensão de espaço de contato e de trocas. A Tese aborda essa dualidade entre separação e ligação afinal, tratam-se de sequestros e desaparecimentos de cunho político, com participação de agentes de ambos países atuando coordenadamente, ocorridos em tentativas de fugas. Logo, fronteira e segurança são uma abordagem presente nesta Tese, principalmente nas ligações de fronteira, nos intercâmbios e no fluxo de fronteira.

\footnotetext{
${ }^{199}$ TURNER, Frederick Jackson. The frontier in american history. New York: Dover, 1996.

${ }^{200}$ Acerca da teoria de Turner de uma fronteira em movimento, cf. AVILA, Arthur Lima de. E da fronteira veio um pioneiro: a frontier thesis de Frederick Jackson Turner (1861-1932). Dissertação de Mestrado PPGHIST/UFRGS, Porto Alegre, 2006.

201 THOMPSON FLORES, Mariana F. da C. Crimes de fronteira: a criminalidade na fronteira meridional do Brasil (1845-1889). Porto Alegre: PUCRS, 2012. Tese de doutorado em História. Programa de PósGraduação em História PUCRS.

${ }^{202}$ CASTELLO, R. Iara. Áreas de fronteira: Territórios de integração, espaços culturalmente identificados? In: ; HAUSEN, C. Ênio et al. Práticas de integração nas fronteiras: temas para o MERCOSUL. Porto Alegre: Ed. da Universidade/UFRGS, Instituto Goethe/ICBA, 1995.
} 
A proposta desta Tese no tratamento da fronteira não compreende uma visão de espaço defensivo e fechado, que se orienta para dentro. Essa seria uma opção reducionista do que ocorre nesse espaço, que abarca, também, uma pluralidade de diferenças e integrações. Sacchetti $^{203}$ expõe que o conceito de fronteira está em construção, assim como a própria fronteira. Constitui uma evolução, no sentido de ampliação, de ambos: a fronteira e o conceito de fronteira. A intenção é apreender a fronteira no aspecto de integração, sob a perspectiva que trata-se de, principalmente, conexões repressivas.

As fronteiras viabilizam fluxos e influências, são superfícies porosas de contato entre Estados, com realidades sociais, econômicas, culturais e políticas distintas. Os contatos entre os cidadãos que ali vivem, bem como os que por ali passaram, não se restringem em apenas uma perspectiva, mas se moldam conforme as condições estabelecidas pela burocracia de ambos os países. Durante os anos de pesquisa e de elaboração da Tese, acerca da questão fronteiriça, foram estabelecidos alguns pressupostos que guiam essa empreitada: fronteirização, fronteira manejada e fronteira ideológica.

Em primeiro lugar, a Tese aborda a fronteirização como proposta por Alejandro Grimson $^{204}$, autor com vasta pesquisa de fronteira e na fronteira que esta Tese trata. Em sua tese de doutorado, o pesquisador se deteve em analisar as relações estabelecidas entre cidadãos de Uruguaiana e Paso de los Libres na larga duração. Chindemi ${ }^{205}$ também se aproxima dessa perspectiva de análise fronteiriça, porém com uma abordagem espacial diferente da de Grimson. Partindo de uma perspectiva pontual, no quesito de espaço, o autor objetiva debater acerca do desafio de entender os diversos significados da nação e as formas em que ela é expressa e vivida pelos sujeitos que habitam o espaço fronteiriço.

Do ponto de vista político e jurídico, os limites de um Estado são definidos por demarcações territoriais baseadas em acidentes naturais ou em convenções internacionais. Grimson se propõe a explicar as fronteiras de uma perspectiva diferente, não a partir de suas características objetivas, como entidades fixas e predefinidas, mas como construções humanas historicamente contextualizadas que condicionam realidades dinâmicas. Entendendo a fronteira como uma construção simbólica em constante reformulação, na qual participam diversos agentes sociais com interesses particulares, o autor sugere o conceito de

\footnotetext{
${ }^{203}$ SACCHETTI, F. E. Antônio. Fronteiras - Novos conceitos questões fronteiriças. Grupo de estudo e reflexão estratégica. Cadernos Novais, Lisboa, n. 6, jul./set. 2003.

${ }^{204}$ GRIMSON, A. La nación en sus límites - Contrabandistas y exilados en la frontera Argentina-Brasil. Barcelona: Editorial Gedisa S/A, 2003.

${ }^{205}$ CHINDEMI, Julia Valeria. Las tradiciones de frontera internacional em Rio Grande del Sur: un análisis em la larga duración. Dissertação (Mestrado) - Universidade de Brasília, Brasília, 1999.
} 
"fronteirização", que funcionaria como uma ferramenta para analisar a constituição e o estabelecimento da fronteira através do tempo.

Para entender esse processo de longa duração, Grimson utilizou a etnografia histórica, que consiste em conjugar de um modo especial etnografia e história. Dessa forma, o autor busca encontrar as origens da fronteira, indo o mais distante que lhe seja possível, para entender como se concretam as identificações vistas como evidentes pela sociedade. $\mathrm{O}$ trabalho de Grimson contempla um processo de afirmação nacional como confrontamento de interesses locais, regionais e nacionais.

O autor propõe entender a nação e a fronteira por meio da população, sujeitos tidos como comuns, que são os que se apropriam dessa fronteira. Os cidadãos fronteiriços são pessoas que incorporam uma nação e uma fronteira ao seu sentido comum. A intelegibilidade dessas pessoas se classifica no âmbito nacional, sua nacionalidade própria e a nacionalidade do vizinho.

A pesquisa de Grimson se constitui em três períodos de análise, com intuito de compreender como burocraticamente foi se constituindo a fronteira entre Brasil e Argentina. Começa discutindo os limites e as disputas ocorridas até a demarcação do território - desse modo, trata desde a colonização até os Estados nacionais, incluindo as disputas que envolvem esses conturbados processos de consolidação - conflitos bélicos, tratados negociados, e as dificuldades em tentar atender interesses do Estado, da população e econômicos, que muito raramente conseguiram contemplar as aspirações de todos os grupos envolvidos.

Na sequência o autor aponta a questão da defesa territorial, ou seja, manter os limites estabelecidos, que constantemente estavam sob ameaças - de fato ou não - de invasão. A fronteira é por si um local de tensão, mesmo em tempos de paz. Segundo Grimson, os Estados nessa conjuntura de consolidar o território trataram de enfatizar um sentimento nacional; assim, por meio das escolas e outras instituições governamentais, se intensificou a propagação de um nacionalismo.

É certo que os sentimentos de invasão eminente, de conflitos bélicos, foram perdendo força com o passar dos anos. Em 1990, as discussões acerca do Mercado Comum do Sul MERCOSUL tomam forma oficial, afastando mais ainda esses rumores de conflito entre Estados. O MERCOSUL aponta para uma integração - no caso, econômica - dos grandes centros produtivos.

Nesse sentido, ainda segundo Grimson, esses acordos com pautas de cunho central e generalistas decepcionaram os cidadãos de ambos os países, já que esses esperavam ter atendidas necessidades de integração pontuais. Uma integração institucionalizada e com 
intuito de atender interesses comerciais e industriais de maior ressonância, além de, na prática, não reverberar no curto prazo, ainda torna mais complexo o processo de fronteira integrada no âmbito local, visto que os controles na fronteira se intensificam sistematicamente. O Estado passa a se presentificar por meio do controle e regulamentação mais do que por meio de políticas públicas. Essa característica está presente quando, após a inauguração da ponte entre Uruguaiana e Paso de los Libres o controle sobre a circulação na fronteira passou a ser mais rígido.

Importa ressaltar que, na análise de Grimson, o relacionamento transfronteiriço entre brasileiros e argentinos não é uno. Cada população vizinha tem suas particularidades e práticas exclusivas, que fazem sentido ligadas aos seus respectivos países, mas não no contexto de fronteira. Ao mesmo tempo, algumas práticas são típicas de fronteira e da fronteira analisada. Dessa forma, Grimson oferece um substrato de análise para essa fronteira:

Es decir, estudiar desde una perspectiva relacional los conflitos, las alianzas y las redes que atraviesan la frontera. Así, resulta necesario analizar las relaciones entre ambas poblaciones, las relaciones entre cada población fronteriza y su respectivo Estado central, y las relaciones entre los diferentes grupos que conformam las poblaciones fronterizas. $^{206}$

Essa é uma das perspectivas elegidas para analisar a fronteira nesta Tese, ou seja abordar a fronteira por meio dos contatos estabelecidos, das redes constituídas e do cotidiano vivenciado, durante o período específico em que os casos repressivos ocorreram.

Outro trabalho significativo acerca de fronteira, e da fronteira tratada aqui, é o de Thompson Flores ${ }^{207}$, que apresenta a "fronteira manejada". Ao estudar, em sua tese de doutorado, crimes de contrabando na fronteira oeste do Rio Grande do Sul entre os anos de 1845 e 1889, Thompson Flores nos apresenta a sua perspectiva de fronteira. Antes de expor sua perspectiva de análise fronteiriça, a autora fez uma síntese debatendo criticamente as diversas correntes de abordagem de fronteira, montando um alicerce consistente para sua proposta de trabalho: a fronteira manejada. Conforme a autora, a fronteira manejada é composta dos seguintes elementos, que sucintamente são:

a) Centralizar no individual sem perder noção das ações macro - Estado e contexto histórico amplo;

\footnotetext{
${ }^{206}$ GRIMSON, A. La nación en sus límites - Contrabandistas y exilados en la frontera Argentina-Brasil. Barcelona: Editorial Gedisa S/A, 2003. p. 25.

${ }^{207}$ THOMPSON FLORES, Mariana F. da C. Crimes de fronteira: a criminalidade na fronteira meridional do Brasil (1845-1889). Porto Alegre: PUCRS, 2012. Tese de doutorado em História. Programa de PósGraduação em História PUCRS.
} 
b) Compreender as ambiguidades de fim e início; de contato e separação;

c) O limite é reconhecido pelos fronteiriços, bem como é aceita a noção de ser estrangeiro e do outro ser estrangeiro;

d) As relações são transfonteiriças, pois perpassam a fronteira, mas não desconsideram as questões simbólicas das diversas identidades;

e) Pressupõe análises "sob medida" para a contextualização;

f) O espaço fronteiriço se altera constantemente;

g) Compreender a fronteira além das relações duais;

h) Os sujeitos fronteiriços não são homogêneos, é preciso compreendê-los em suas singularidades e recursos com que lidam com a fronteira, visto que é um local estratégico para os indivíduos. ${ }^{208}$

Dito isso, as considerações acerca de "fronteira manejada" são de grande valia para essa Tese, principalmente em dois aspectos: recursos dos indivíduos e análise sob medida. Os recursos, já que a forma como as experiências vivenciadas na fronteira pelos diversos agentes são diferenciadas conforme sua posição (social, política, financeira). E a análise sob medida dos casos abordados no decorrer da Tese, serão pontuados alguns dos indivíduos que se apresentam nesta Tese e sua diferenciação para com os demais, que justifica sua presença na análise.

A experiência de um Cônsul na Aduana não é a mesma de uma pessoa que estava em fuga - assim como ambos não se aproximam da experiência de um agente de segurança brasileiro ou argentino, ou de um "chibeiro" 209 . Ou seja, todos estão imbricados em uma situação comum - cruzar a fronteira -, e todos estão atuando e praticando uma experiência única, já que suas perspectivas e seus recursos são diferentes. Dessa forma, cada caso de que trata esta Tese será abordado conforme sua especificidade, no que se refere aos recursos e objetivos na fronteira, mas inseridos no contexto histórico que emoldura esse cruze, que é o contexto sob medida.

\footnotetext{
208 THOMPSON FLORES, Mariana F. da C. Crimes de fronteira: a criminalidade na fronteira meridional do Brasil (1845-1889). Porto Alegre: PUCRS, 2012. Tese de doutorado em História. Programa de PósGraduação em História PUCRS. p. 71-72.

${ }^{209}$ Conhecidos como "chibeiros" as pessoas que atravessam a fronteira com compras efetuadas no país vizinho. Ou seja, conforme o câmbio um cidadão atravessa a fronteira para comprar produtos para revender em seu país, esses produtos que podem ser eletrônicos, alimentos, objetos de uso pessoal são conhecidos como "chibo".
} 
Ao abordar casos de sequestro/desaparecimento ocorridos sob conexões repressivas entre governos, faz-se necessário explicar como isso pode ser possível, de que forma essas experiências se reverberam, como se sucederam, quais experiências carregavam e de que maneira isso se fundiu na repressão desta fronteira.

Nesse ponto, apresenta-se a terceira definição de fronteira da Tese, que é a de fronteira ideológica. Como visto no primeiro capítulo, o Rio Grande do Sul foi uma das rotas de fuga utilizadas durante os anos ditatoriais devido à sua localização contígua a Uruguai e Argentina. Nesse sentido, as fronteiras como rota de fuga/salvamento agregam uma conotação ideológica, superando-se o conceito tradicional de limite, de separação, em favor da ação repressiva de colaboração de agentes de nacionalidades diferentes.

Quando "del otro lado del río, los perseguidos ya no estaban a salvo. Al desarrollarse una coordinación supranacional, sin distinciones de soberania, la represión política no tenía fronteras ${ }^{, 210}$, ou seja, atravessar a fronteira não garante segurança, exilado ou não, se percebe que os limites geográficos e burocráticos se tornam no contexto repressivo um expediente não prioritário, em prol de garantir a segurança do Estado, e dos Estados que se unem para garantir a segurança dos regimes castrenses.

As ditaduras articuladas agiam em diferentes países; a fronteira ideológica preocupava-se não só com o "meu inimigo interno" mas também com o "inimigo interno do outro", que torna-se um "inimigo interno e externo", interno em seu país e externo quando ultrapassa a fronteira. Conforme Fernandes:

\begin{abstract}
$\mathrm{Na}$ concepção de "fronteiras ideológicas", diante da ameaça e da expansão do comunismo para o "Mundo Livre", as fronteiras territoriais e geográficas não estavam mais em questão. Elas poderiam ser ultrapassadas, visto que não havia mais soberania nacional a ser respeitada quando os valores da civilização democrática e cristã estivessem sendo ameaçados. Assim, o que importava era a ideologia vigente no governo em questão ou se havia algum grupo/movimento que pudesse desestabilizar o governo. Desse modo, na lógica da Doutrina de Segurança Nacional, invasões e interferências em países considerados de perfil "comunista" ou ameaçados por ele seriam consideradas naturais, a fim de manter sua segurança interna. $^{211}$
\end{abstract}

A segurança assume um caráter transnacional, na medida em que o inimigo não é mais um Estado estrangeiro, mas organizações estruturadas em rede, fundadas em critérios de solidariedade que pouco tem a ver com o sentimento de pertencimento a um Estado Nacional

${ }^{210}$ GRIMSON, A. La nación en sus límites - Contrabandistas y exilados en la frontera Argentina-Brasil. Barcelona: Editorial Gedisa S/A, 2003. p. 186.

211 FERNANDES, Ananda S. A perseguição além fronteira: os orgãos de repressão e espionagem da ditadura brasileira para o controle dos exilados no Uruguai. Estudios Historicos - CDHRP, n. 1, p. 2, maio 2009. 
- nesse caso, o dos "inimigos internos" que tentavam fugir de seus países através das fronteiras. Todo cidadão que estivesse posicionado contra seu governo era tido como inimigo e assim deveria ser tratado, como já demonstrado nesta Tese. Desta forma o próximo capítulo tem como objetivo demonstrar conexões estabelecidas nessa fronteira e o seu funcionamento. 


\section{CONEXÕES NA FRONTEIRA URUGUAIANA-PASO DE LOS LIBRES}

No transcorrer das mais recentes experiências ditatoriais vivenciadas no Brasil e Argentina, a fronteira Uruguaiana-Paso de los Libres apresentou características singulares nesse contexto. Foram experiências internas e externas, já que uma sociedade influencia a outra no cotidiano fronteiriço. O objetivo de ambos os Estados, naquele momento sob intervenção das forças armadas e respaldados por parcelas no campo civil da sociedade, era de evitar qualquer tentativa de manifestação contrária ao seu ilegítimo governo. Dessa forma, os olhares que os mandatários oferecem para as fronteiras e as ações políticas executadas se transfiguram. O Brasil sob ditatura ininterrupta desde 1964 constitui uma agenda muito mais complexa e definida, no sentido de implantar diversas burocracias para as regiões de fronteira, do que a Argentina que passou por diversos golpes de Estado até o derradeiro de 1976, que implantou o Terrorismo de Estado.

Desta forma, entende esta Tese que o Terrorismo de Estado no Brasil foi implantado de modo paulatino, apropriando-se de espaços outrora democráticos. Foi diferente da Argentina onde, após o golpe militar, houve imedita implementaçãoo da prática de prisões clandestinas e desaparecimentos.

O governo brasileiro instituiu uma agenda que contemplava as regiões de fronteira desde os anos 1960. Por ela o aparato repressivo atuação e alcançou dimensões sem precedentes, bem como a colaboração entre as instituições de segurança pública brasileiras e argentinas de modo a permitir que atividades repressivas binacionais fossem executadas.

\subsection{Composição da repressão em Uruguaiana e Paso de lós Libres}

Em 4 de junho de 1968, foi assinada pelo Presidente Costa e Silva a Lei 5.449, que declarava alguns munícipios como área de interesse da segurança nacional. Esta lei definia regras para, inicialmente, 71 municípios brasileiros, dentre os quais 24 gaúchos, incluindo Uruguaiana. O primeiro artigo da lei listou as cidades incluídas e o segundo artigo estabeleceu novas regras políticas para esses munícipios: deste dia em diante, os prefeitos das cidades listadas,passariam a ser nomeados pelo governador de seu respectivo Estado, desde que esse fosse aprovado pelo Presidente da República. ${ }^{212}$ Esta lei não se referia aos vereadores; sendo assim, os eleitores poderiam votar em seus edis, mas não no prefeito. Entende-se que

${ }^{212}$ Lei 5.449 de 04 de Junho de 1968. Disponível em: http://www.planalto.gov.br/ccivil_03/leis/19501969/L5449.htm acesso em 20/06/2014. 
Uruguaiana estivesse nesse grupo devido à sua localização, enquanto outras cidades foram declaradas como área de interesse de segurança nacional por ter, segundo a repressão, um número substancial de organizações contrárias ao governo.

A institucionalização das regiões de fronteira como áreas sensíveis do ponto de vista da segurança, com clara preocupação com a região sul, remete ao trabalho do General Golbery Couto e Silva ${ }^{213}$ acerca da geopolítica brasileira. Golbery, quando escreveu sobre fronteiras, pontuou duas grandes áreas: bacia do Amazonas e bacia do Prata, sendo que a segunda concentraria tensão máxima no aspecto de segurança. Dessa forma, foi significativo o número de munícipios da região sul que se tornaram área de interesse de segurança nacional por questão geopolítica e com critérios ideológicos e políticos do regime ditatorial, reverberando o discurso estatal de garantir a ordem e dando substrato para a implantação de outras medidas com intuito de, cada vez mais, impor o fim da democracia.

Nos regimes autoritários as decisões, em geral, não precisam ter apoio dos políticos locais, assim como não dependem da simpatia das sociedades afetadas. Dessa forma, a inclusão de Uruguaiana na lista de cidades em área de interesse da segurança nacional não foi uma decisão que agradou os vereadores de Uruguaiana. No acervo da Câmara Municipal de Uruguaiana $^{214}$, a primeira menção encontrada sobre este tema ocorreu em sessão realizada em 19 de abril de $1968^{215}$ : o vereador Arnaldo D'Augustin Ribeiro apresentou um requerimento para que fosse encaminhada uma carta para alguns deputados pedindo apoio para que Uruguaiana fosse excluída da lista. Esse tema voltou ser debatido nas duas sessões posteriores, em 25 e 30 de abril de 1968. Aprovada por todos os presentes na sessão de 30 de abril de 1968, a correspondência foi enviada em 2 de maio de 1968. Parte do texto justificava o pedido de exclusão nos seguintes termos:

[...] Nada justifica tal medida que visa cassar os direitos cívicos de uma das comunidades mais politizadas do país e com um acervo dos mais gloriosos da história pátria. A medida incluindo Uruguaiana como área de segurança, não só é desaconselhada porque possui fronteiras com países tradicionalmente amigos, como também, poderá trazer desconfiança e sentimentos incompatíveis com os princípios panamericanos de confraternização dos povos do nosso continente. ${ }^{216}$

\footnotetext{
${ }^{213}$ SILVA, Golbery C. Geopolítica do Brasil. Rio de Janeiro: José Olympio, 1967.

${ }^{214}$ A pesquisa foi realizada primeiro no registro das atas de sessões da Câmara e posteriormente nos documentos relativos aos anos pesquisados, que foram: 1964, 1967 à 1969, 1976, 1979 e 1980.

${ }^{215}$ Câmara Municipal de Uruguaiana. Ata número 10. 19 de Abril de 1968. Uruguaiana/RS.

${ }^{216}$ Câmara Municipal de Uruguaiana. Ofício número 2/68. 02 de maio de 1968. Uruguaiana/RS.
} 
Os deputados que receberam essa carta foram: Aldo Fagundes, Alcides Flores Soares Junior, Paulo Brossard de Souza Pinto, Vasco Amaro da Silveira e Jairo Brum, Adylo M. Viana, Cunho Bunho, Vitorino James, e dois senadores: Daniel Krieger e Aurélio Viana. Antes do envio dessa carta, os dois receberam apoio do Senador Mário Martins, que afirmou ser, em conjunto com o Movimento Democrático Brasileiro (MDB), seu partido, contra essa medida restritiva.

Dos deputados e senadores que receberam pedido de apoio dos vereadores uruguaianenses, somente encontram-se, no acervo da Câmara de Vereadores, registro de resposta do deputado Aldo Fagundes, recebido dia 13 de maio de 1968. No final do mês de maio, a Câmara Municipal recebeu desse mesmo deputado uma carta com uma síntese dos acontecimentos sobre a temática em questão.

O deputado conta que recebeu três documentos referentes ao tema da área de segurança e que os leu e comentou na tribuna, tentando, sem sucesso, excluir Uruguaiana por meio de emenda. O projeto, que vinha sendo debatido em grupos de parlamentares de diversos estados e acompanhado por vereadores de cidades incluídas no que o deputado chama de "mensagem", sequer foi colocado em discussão no Congresso para ser votado. Ainda nesta correspondência, Aldo se compromete em seguir tentando excluir Uruguaiana das áreas de segurança nacional, por meio de alteração na lei. ${ }^{217}$ Mesmo com uma aparente intensa movimentação política, os pedidos antes e após a promulgação da Lei 5.449 não foram atendidos, e Uruguaiana não foi excluída das áreas de interesse de segurança nacional.

Interessa perceber que os edis uruguaianenses, na justificativa que foi enviada aos deputados, alegam que essa fronteira comporta nações amigas, e que essa medida poderia gerar desconfianças acerca de um possível conflito. Vale ressaltar que essa justificativa não serviria para demover o Poder Executivo da escolha de Uruguaiana - para as ditaduras de segurança nacional importava o "inimigo" interno, conter a "subversão" e monitorar a entrada e saída de "suspeitos", e nesse aspecto Uruguaiana é uma das áreas mais sensíveis e estratégicas, rota de fuga de "inimigos". Como se demonstra por meio de documento do Arquivo Nacional que trata sobre Luiz Carlos Prestes. Em março de 1968, sinaliza que este poderia utilizar essa fronteira para fuga:

\footnotetext{
${ }^{217}$ Câmara Municipal de Uruguaiana. Carta Deputado Aldo Fagundes para o Presidente da Câmara Municipal de Uruguaiana Nivaldo Soares. Pasta documentos recebidos 1968. 31 de maio de 1968.
} 
b) Outro informe diz que há possibilidade dele [Luiz Carlos Prestes] atravessar a fronteira em URUGUAIANA e neste caso usaria a cidade de PASO DE LOS LIBRES, na ARGENTINA para o início de sua viagem.

c) $\mathrm{O}$ item $\underline{b}$ focaliza uma possibilidade, razão pela qual não se deve abandonar a hipótese deste deixar o BRASIL diretamente para a Europa $\left[\ldots . .{ }^{218}\right.$

Enquanto Uruguaiana presentificava a intervenção militar direta na política local com o impedimento de eleições para o Poder Executivo, Paso de los Libres sedimentava paulatinamente a repressão em sua fronteira com a proliferação de instituições de segurança, amparando-se na hipótese de um conflito bélico entre Brasil e Argentina. Essa tese era difundida pelas elites militares e apoiadores dos golpes dos dois países, pois interessava utilizar essa justificativa para evitar a exposição da institucionalização do Terrorismo de Estado, que já vinha se desenhando e sendo discutido entre os militares.

Sobre a percepção argentina acerca de um conflito bélico, Guglialmelli comenta: "negociar desde adecuadas condiciones de fuerza y con la firme convicción de enfrentar, en caso necesario, las peores alternativas, incluido el conflito armado". 219 Nos anos 1970, diversos artigos com o teor do citado foram publicados na Argentina, tratando de uma possível guerra entre Brasil e Argentina. Apesar da difusão dessas hipóteses de guerra entre os países, no que se refere às ditaduras de segurança nacional, é dado que de fato não era esse o motivo da ampliação do aparato militar, mas sim garantir a ordem interna e eliminar os "inimigos" do Estado, primeiro em seu país e depois onde estivessem foragidos.

A Argentina, assim como o Brasil, também criou leis com intuito de garantir a segurança de suas fronteiras; essas leis contemplavam uma gama bem plural de ações, como incentivar o povoamento, investir, integrar - ou seja, inserir essas fronteiras nos projetos nacionais. Até os anos 1960, não havia uma preocupação efetiva institucional em relação a esses locais; legitimá-los enquanto parte da nação e ao mesmo tempo caracterizá-los em suas peculiaridades foi uma das agendas para todas as fronteiras argentinas dos anos $1960 \mathrm{em}$ diante. $^{220}$

A atuação governamental argentina durante o Terrorismo de Estado é dupla também no quesito fronteira: ao mesmo tempo em que instalava escolas, ampliava a infraestrutura e buscava integrar essas regiões mais afastadas de Buenos Aires, também estendia o aparato

${ }^{218}$ BR_AN_BSB_VAZ_021A_0090. Viagem planejada por Luiz Carlos Prestes. Ministério Aeronáutica Quarta Zona Aérea Quartel-General 2a Seção. 04 de Março de 1968. Arquivo Nacional.

${ }^{219}$ GUGLIALMELLI, Juan. Argentina-Brasil: enfrentamiento o alianza para la liberación. Estratégia, Buenos Aires, n. 36, 1975.

${ }^{220}$ O governo militar de 1966 iniciou essa série de leis específicas para a fronteira, assim como o iniciado em 1976 também criou normas para essas regiões, algumas das leis: ley 18.575; ley 19.24, decreto 2336 de 1978. 
repressivo instalando grupos de controle, aumentando o número de militares e unidades das forças de segurança, e mantendo centros clandestinos de detenção que serviram para prisão, tortura e morte de perseguidos políticos.

Duas vias, diurna e noturna: durante o dia, ou seja, às claras, amplia a gama de benfeitorias para a população em geral, agregando apoio social para o regime; à noite, ou seja, no escuro, para que ninguém possa ver, sequestra, mantém em cativeiro, tortura, mata e desaparece com o corpo. Sem corpo, sem prova? Essas atuações não eram noticiadas. Assim como agia "turco Julián" "221, que durante as tardes de inverno oferecia casacos para crianças de rua na aduana e contava piadas para os agentes, ao mesmo tempo que, de portas fechadas em sua sala, na mesma aduana, interrogava supostos "subversivos", interrogatório que nesse contexto entende-se como depoimentos sob coerção e tortura.

A militarização da região de Uruguaiana e Paso de los Libres nos anos 1970 estava consolidada, bem como a estrutura e logística de controle aduaneiro sistematizada. Paso de los Libres contava com uma emissora de rádio do Estado, tinha prefeitura, polícia federal, aduana instituída, serviços de inteligência, polícia provincial, gendarmeria e três regimentos militares que compreendiam uma média de três mil homens servindo as forças armadas.

Ao mesmo tempo que as redes estabelecidas entre militantes, de diversos grupos e ideologias díspares, de ambos os países foram se estabelecendo e consolidando, e não foram novidade da década de 1970 :

Desde la década de 1950 hasta el tercer gobierno de Perón en 1973 había militantes peronistas que concurrían desde ciudades brasileñas y desde Buenos Aires hasta la frontera. Porque aunque el exilio en Uruguayana se limito a los años inmediatamente posteriores al golpe de Estado, la presencia del peronismo en ambas ciudades de frontera se extendió un tiempo mayor. ${ }^{222}$

A fronteira Uruguaiana-Paso de los Libres sempre foi mais do que apenas um espaço de passagem entre Porto Alegre e Buenos Aires, pois grupos políticos brasileiros e argentinos se organizavam nos dois municípios, atuando em conjunto, principalmente com a militarização de seus países. O que aconteceu na década de 1970 foi uma mudança significativa no modo de articulação das redes de repressão promovidas pelo aparato estatal, assim como nas redes de solidariedade que se intensificam e se ressignificam devido uma nova modalidade de repressão, a formalização de um acordo entre ditaduras.

${ }^{221}$ Turco Julián um dos torturadores mais conhecidos da Argentina, e atuou na fronteira Uruguaiana-Paso de los Libres.

${ }^{222}$ GRIMSON, A. La nación en sus límites - Contrabandistas y exilados en la frontera Argentina-Brasil. Barcelona: Editorial Gedisa S/A, 2003. p. 178. 
A mudança significativa ocorrida na fronteira é que até os anos 1970 esse local era visto como de certa segurança pelos militantes de diversas nacionalidades que passavam por ali. Era um lugar para escapar da repressão em seu país; atravessar a fronteira dava segurança, no sentido de não ser mais um "inimigo" do Estado que deveria ser combatido.

Com os governos militares articulados, a fronteira passa a ser uma zona de perigo, buscar a proteção no país vizinho não era garantia de eficácia, visto que os aparatos repressivos operavam além fronteira. Além disso, difere de outros períodos, pois na década de 1970 e 1980 as redes não eram as mesmas dos tempos de peronismo na Argentina e trabalhismo no Brasil. Em geral, essa fronteira - por não ser mais segura para quem precisava fugir da repressão - se torna um lugar de passagem para os militantes políticos, se torna um corredor. A fronteira deixa de ser lugar de exílio, já que praticamente não existem contatos significativos do outro lado do rio, e passa ser um local de "cruce". Portanto, também nesse caso se demonstra a fronteira manejada conforme as peculiaridades do processo histórico. As fronteiras não são regiões em que prevalece equilíbrio político, econômico, há protagonismo de um dos países limítrofes, conforme a conjuntura esse protagonismo se altera.

\subsection{O cruze de fronteira - El cruze de la frontera: cotidianos fronteiriços}

É intuito desse item dessa Tese apontar como a alfândega entre Uruguaiana e Paso de los Libres funcionou durante as últimas ditaduras do Brasil e Argentina, partindo das burocracias já existentes, ou as criadas especificamente nos anos ditatoriais, e demonstrando como se davam os intercâmbios fronteiriços, e como a agenda política local lidou com a intervenção militar. É uma abordagem pontual e específica dos processos ocorridos nessa fronteira e nos anos dos casos estudados nesta pesquisa.

Como funciona o, dito, corredor Uruguaiana-Paso de los Libres? As cidades são separadas e unidas pela ponte internacional - abaixo mapa para visualização desse espaço. Para que se entenda que o modo como se efetiva o duo: ligação - separação, é preciso ressaltar que uma fronteira seca, como, por exemplo, a de Santana do Livramento e Rivera: Brasil e Uruguai, tem um modo de vivenciar as experiências repressivas no mesmo período e com aparato similar, muito díspare do que o estudado na fronteira tema desta Tese. Há uma diferença substancial entre, no exemplo proposto, a divisa ser uma rua, e no caso desta Tese, ser uma ponte. 
Os procedimentos são diferentes, as ações secretas ou não, são talhadas de outra forma. Conforme analisa Aseff acerca das cidades geminadas Livramento-Rivera, a fronteira seca possibilitou que perseguidos políticos fossem salvos por estar a poucos metros do outro país, "Em Livramento, dezenas de ruas atravessavam os dois países, unindo as cidades em uma só dimensão". ${ }^{223}$ A contraponto da divisa ser uma ponte que conta com fiscalização nas cabeceiras de ambas as margens, em que se a travessia não for efetuada de modo oculto, como, por exemplo, de barco à noite, não há como evitar as instituições de segurança, o controle é mais rigoroso. Nem a "obsessiva vigilância militar conseguia vasculhar a extensa região de fronteira seca com o Uruguai" ${ }^{224}$. Portanto, do ponto de vista de fuga dos brasileiros - ou que estavam no Brasil -, a fronteira de Livramento, pela logística, era melhor opção que Uruguaiana. Assim como, para quem estava em fuga da Argentina, a fronteira com Uruguaiana era melhor opção do que tentar escapar via aérea.

Em ambas as cidades estudadas para esta Tese, existe uma estrutura alfandegária para que as instituições estatais operem na região. É um lugar a priori de controle, que conta com diversas instituições do Estado operando em diferentes esferas (controle de mercadorias, de impostos, de pessoas etc.), com flexibilidade nas operações e instituições que ali permanecem conforme a conjuntura política, econômica e social. Durante o TdE, o que se destacava era a presença de agentes de segurança de ambos os países, pois esse era o foco estatal para a aduana e a fronteira, bem mais que o controle de mercadorias, a primeira motivação não exclui a segunda, e os controles de mercadorias seguiram ocorrendo e inclusive causando conflitos, como se percebe nos caso dos televisores, tratado em seguida.

\footnotetext{
${ }^{223}$ ASEFF, Marlon Gonsales. Retratos do exílio: solidariedade e resistência na fronteira. Santa Cruz do Sul, RS: EDUNISC, 2009. p. 95.

${ }^{224}$ Ibidem, p. 95.
} 


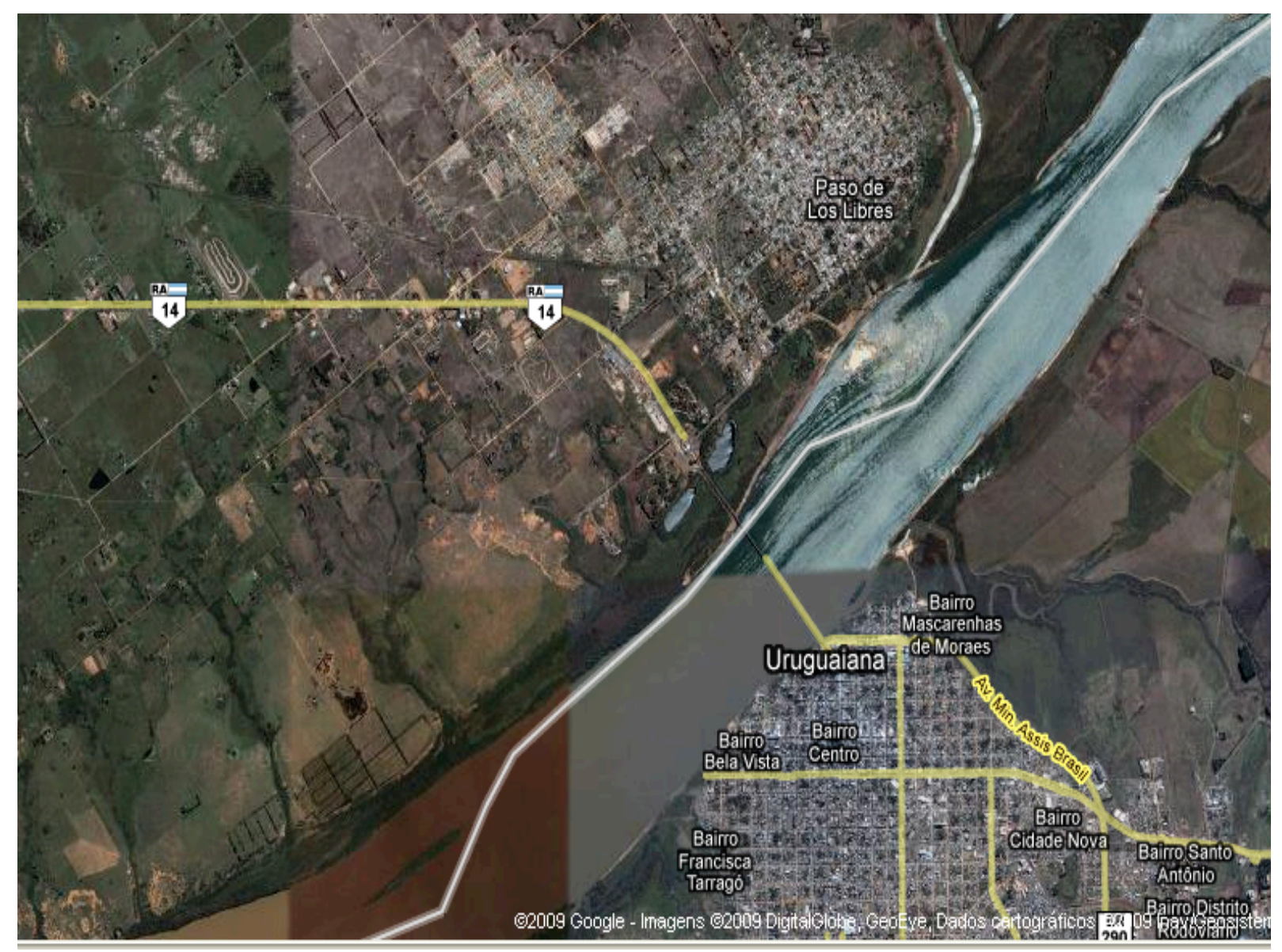

Figura 4 - Mapa demonstrativo da região estudada nesta Tese: Uruguaiana-Paso de los Libres

Fonte: Google Maps (2009).

\subsection{A aduana}

Ao cruzar a ponte no sentido Brasil-Argentina está localizada a aduana internacional $^{225}$, onde via de regra todas as pessoas deveriam ser paradas para fins de fiscalização, o que na prática não ocorre; nem todos os veículos são revistados, por exemplo, e não são todas as pessoas que precisam apresentar documentos - essa escolha de quem será parado ou não é algo subjetivo, já que não existe uma regra firmada que deva ser seguida pelos funcionários alfandegários. Percebe-se que, nas operações rotineiras, os agentes atuam conforme a quantidade de veículos automotores - ou em casos de denúncias, que ocorrem com bastante frequência, o procedimento adotado difere do usual.

${ }^{225}$ O lado brasileiro também conta com estrutura alfandegária, mas essa é voltada ao transporte internacional de cargas, não se detendo na fiscalização de pessoas. 
Neste local estão os órgãos que atuam na alfândega de ambos os países. Abaixo uma planta baixa da estrutura aduaneira - disposição dos anos 1979 até 1983, localizada em território argentino.

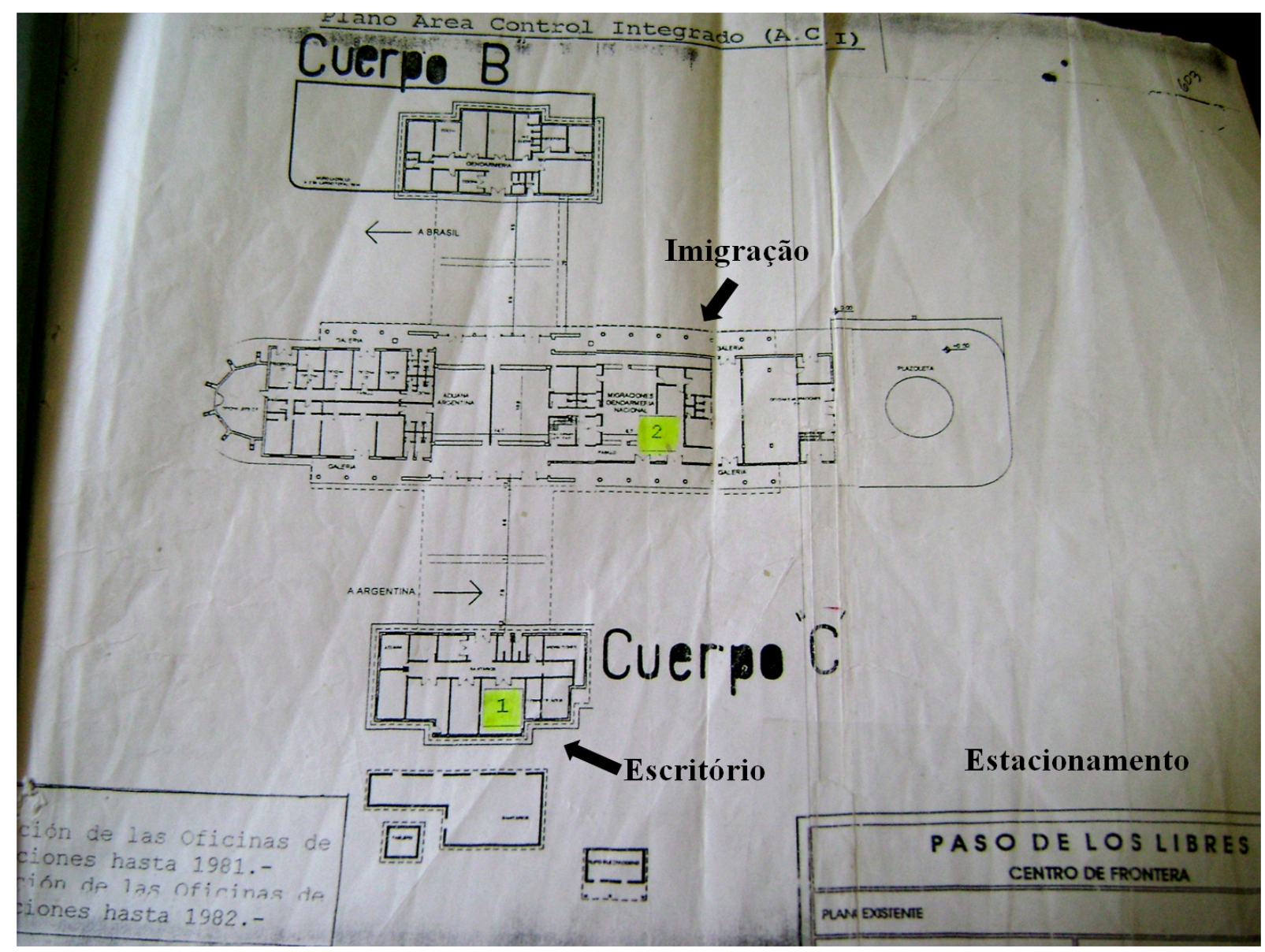

Figura 5 - Juzgado Federal de Paso de los Libres.

Fonte: Adaptado da planta baixa da Aduana (1983).

A estrutura da aduana em 1979 e 1980 era constituída pelas seguintes construções: cuerpo $b$ destinado para a Gendarmeria Nacional Argentina; parte central, onde estavam os órgãos migratórios de Brasil e Argentina; e cuerpo $C$, que não tinha uma designação oficial no período citado na planta baixa - esse cuerpo foi utilizado por agentes da repressão com objetivo de identificar possíveis "subversivos" que estivessem tentando atravessar a fronteira, e caso fosse feito o trajeto por terra não haveria como evitar esse local. Para entrar ou sair do estacionamento é necessário passar ao lado dessa construção. Para ingressar no Brasil ou na Argentina, é preciso que se "cruze" esse local ${ }^{226}$. O local que está identificado como escritório na imagem acima foi demolido entre 2012 e 2013, e uma nova construção foi edificada para

${ }^{226}$ É de conhecimento público que ocorrem ingressos clandestinos em ambos os países, realizados geralmente no período noturno por meio de barcos, mas não é este o tipo de travessia abordado nesta Tese. 
abrigar um setor da Direción Nacional de Migraciones específico para atender passageiros de ônibus, além de uma casa de câmbio.

\subsubsection{Aduana Uruguaiana-Paso de los Libres no final dos anos 1970}

O ano de 1980 foi o que os jornais de Uruguaiana, consultados na pesquisa dessa Tese, classificaram como de "invasão argentina". Na retrospectiva de 1980, o periódico local "O Jornal de Uruguaiana" ${ }^{, 22}$ publicou que em torno de 3.600 .000 argentinos ingressaram no Brasil por meio da fronteira Uruguaiana-Paso de los Libres - uma média de dez mil argentinos por dia, segundo dados fornecidos pela Gendarmeria Nacional Argentina ao jornal.

Essa "invasão", conforme informa o jornal, teria sido motivada principalmente pela compra de aparelhos televisores: até 18 de julho daquele ano, a média de televisores vendidos era de 400 nos dias úteis e 800 aos sábados; após essa data, devido à restrição de compras imposta pelo governo argentino, a média diária caiu drasticamente, para algo em torno de dez aparelhos vendidos por dia. ${ }^{228}$

Em matéria publicada em maio de 1980, "João o Jornal do Povão"229 traz reportagem sobre o elevado número de argentinos ingressando em Uruguaiana no primeiro final de semana desse mês, e também se refere como "invasão". A reportagem está dividida em tópicos: comércio, trânsito, acomodação, camelôs, transporte e alfândega. As lojas tiveram de abrir de madrugada e já havia fila em suas portas para compras, principalmente de televisores; vários acidentes de carros ocorriam durante todo o dia, ruas lotadas de argentinos de diversos lugares, falta de acomodação - algo que já era corriqueiro mas, segundo a crônica, teve seu ápice nesse começo de maio de 1980, pois além dos hotéis sem vagas, as acomodações em casas de famílias também não dispunham de quartos, o que gerou relatos de famílias dormindo ao ar livre ou em seus automóveis. O motivo para tantas pessoas na cidade seria o feriadão de $1^{\mathrm{o}}$ de maio. $\mathrm{O}$ jornal informa que foi impossível controlar todos, visto que somente um funcionário estava trabalhando na aduana argentina neste final de semana. ${ }^{230}$

\footnotetext{
${ }^{227}$ O Jornal de Uruguaiana foi fundado em 1980, pela Editora Três Fronteiras Ltda. Luiz Fernando Valls era o diretor e contava em 1980 com três redatores. Impresso em São Borja não consta tiragem.

228 3,6 milhões de argentinos estiveram aqui em 1980. O Jornal de Uruguaiana. Uruguaiana/RS, 31/12/1980 e 01/01/1981, número 36, ano 1. Retrospectiva 1980.

${ }^{229}$ Esse jornal foi fundado também em 1980, de propriedade da ABC Editora Jornalística tinha como diretora Vavá D. Arriaga Dias contava com dois redatores e 14 colaboradores.

${ }^{230}$ Em um dia Uruguaiana recebeu mais de 2.500 turistas argentinos. João: o Jornal do Povão. Uruguaiana, 08/05/1980, número 34, ano 1, p. 12.
} 
A significativa quantidade de argentinos em busca de televisores se deu pelo câmbio favorável à estes - desde 1979 essas viagens para compras em Uruguaiana ocorriam com mais frequência; moradores de Buenos Aires, Córdoba e até Tucumán se dirigiam para essa fronteira com intuito de fazer compras. Esse número expressivo de pessoas, pelo menos até agosto de 1980, não tinha como ser controlado individualmente na aduana. Do lado brasileiro, a restrição mais vigiada era quanto ao alho argentino, por receio de proliferação de uma praga nas plantações brasileiras. Segundo o Ministério da Agricultura, esse produto era muito utilizado por agricultores brasileiros, e na atualidade ainda é um dos produtos que o Brasil importa em grande quantidade da Argentina.

No que se reporta ao processo aduaneiro de "cruze", segundo reportagem do periódico “João O Jornal do Povão", em matéria acerca das restrições na fronteira, noticiou-se que "na aduana brasileira, está funcionando o esquema especial para facilitar a passagem de automóveis e ônibus"231. A conjuntura influenciava o controle de aduana; nesse caso, para essa região interessava facilitar a entrada de argentinos no Brasil, por questões econômicas. E nesse contexto pode-se entender que também ficou facilitada a entrada de militantes políticos, visto que havia uma flexibilização do controle e um fluxo muito alto de pessoas neste posto aduaneiro.

Não só o comércio foi afetado pela quantidade elevada de turistas argentinos em Uruguaiana, conforme comenta "O Jornal de Uruguaiana"; a falta de estrutura e organização para atender essa demanda foi motivo indireto para que o prefeito fosse substituído: "Ainda em março, a Prefeitura decidiu instituir o 'calçadão' no centro, que acabou acelerando o desgaste de Barros Coelho"232. Em apenas um mês o calçadão foi desativado.

Sobre a substituição do Prefeito, uma matéria específica do periódico citado acima aponta que: "decidida em Porto Alegre, sem qualquer consulta aos políticos locais, a volta do Coronel Antônio Brasil Carús surpreendeu até o antigo Prefeito, Francisco Barros Coelho, que ficou sabendo de seu afastamento através da imprensa”. Carús já havia sido prefeito - e quando os uruguaianenses puderam novamente eleger o representante do executivo, Carús foi eleito prefeito e em elição posterior vereador.

\footnotetext{
${ }^{231}$ Muita expectativa em torno das restrições argentinas. João: o Jornal do Povão. Uruguaiana/RS, 18/07/1980, número 51, ano 1, p. 08.

${ }^{232}$ A "invasão" argentina mudou a cidade. O Jornal de Uruguaiana. Uruguaiana/RS, 31/12/1980 e 01/01/1981, número 36, ano 1. Retrospectiva 1980.
} 
Ao ser nomeado prefeito em maio de 1980, estava atuando no governo estadual como secretário dos transportes, e, ainda conforme o jornal, "o novo prefeito trazia como principal objetivo político a conciliação no partido do governo". ${ }^{233}$ Porém, se essa era a intenção principal, não foi alcançada; todos os vereadores, incluindo os do partido do governo, se posicionaram contra essa medida, e teceram muitas críticas ao processo de indicação do prefeito. Ninguém foi consultado em Uruguaiana sobre essa troca.

Importante ressaltar que conforme a situação de área de interesse de segurança nacional o prefeito, segundo a Lei 5.449:

\footnotetext{
Art. $4^{\circ}$. Os prefeitos nomeados, nos termos dos artigos anteriores, serão exonerados quando decaírem da confiança do Presidente da República ou do Governador do Estado.

Parágrafo único. Comunicado pelo Presidente da República, por intermédio do Ministro da Justiça, ao Governador do Estado, que o Prefeito deixou de merecer confiança, deverá ser imediatamente exonerado. ${ }^{234}$
}

Afirmar que Barros Coelho por algum motivo deixou de merecer a confiança do presidente da república ou do governador com base apenas no que foi divulgado pelos jornais seria no mínimo imprudente. Mais significativo é que a Lei 5.449 dava total respaldo para que o prefeito fosse afastado sem aviso ou consulta prévia aos políticos locais, ou quem quer que seja. Os vereadores de Uruguaiana não foram favoráveis, alguns por causa da volta de Brasil Carús e todos devido ao modo como foi tomada essa decisão. Barros Coelho ficou sabendo pela manhã e de tarde Carús já estava assumindo a prefeitura. Na primeira ata da Câmara Municipal de Uruguaiana após a troca de prefeito todos os vereadores concordaram com as críticas feitas ao Poder Executivo acerca dessa questão. ${ }^{235}$

A “invasão argentina” entre os anos de 1979 e 1980 também impulsionou o aumento na criminalidade - uma consequência já esperada, devido ao aumento significativo de pessoas com quantias consideráveis de dinheiro circulando na cidade. Assim, o número de homicídios nos quatro primeiros meses dobrou em relação aos anos anteriores. ${ }^{236}$

\footnotetext{
${ }^{233}$ Uma surpresa na política: a troca de Prefeito. O Jornal de Uruguaiana. Uruguaiana/RS, 31/12/1980 e 01/01/1981, número 36, ano 1. Retrospectiva 1980.

234 Lei 5.449 de 04 de Junho de 1968. Disponível em: http://www.planalto.gov.br/ccivil_03/leis/19501969/L5449.htm acesso em 20/06/2014.

${ }^{235}$ Câmara Municipal de Uruguaiana. $1^{\circ}$ Período Legislativo. Sessão Ordinária. Ata número 05. 08 de maio de 1980. Uruguaiana/RS.

${ }^{236}$ Em um dia Uruguaiana recebeu mais de 2.500 turistas argentinos. João: o Jornal do Povão. Uruguaiana/RS, 08/05/1980, número 34, ano 1, p. 12.
} 
Em 1979, o Brasil completava 15 anos de "intervenção cívico-militar"237, enquanto a Argentina estava em seu terceiro ano sob experiência de Terrorismo de Estado. Em Uruguaiana, no dia 31 de março de 1979, houve uma série de atividades promovidas pelo Estado para comemorar a, denominada, intervenção, chamada também de revolução democrática por alguns periódicos. Conforme o "Jornal Ilustrado",238 aponta em matéria de capa: "Na tarde do dia 31 de março foi condignamente assinalado o transcurso do $15^{\circ}$ aniversário da Revolução Democrática de 1964"239. As atividades, segundo o jornal, constaram de um ato cívico realizado na Praça Barão do Rio Branco (a principal da cidade) em frente a Catedral Diocesana, missa realizada pelo Bispo Dom Augusto Petró, e desfile militar.

As autoridades presentes eram o general de brigada Everaldo de Oliveira Reis Comandante da $2^{\text {a }}$ Brigada de Cavalaria Mecanizada de Uruguaiana; vereador José Gomes de Souza; prefeito interino José Alcebíades Perrone de Oliveira; capitão de corveta Júlio Cesar Ferreira da Silva; o delegado da Capitania dos Portos de Uruguaiana; juiz de direito e Corpo Consular e autoridades civis e militares de Paso de los Libres ${ }^{240}$. Além das mais importantes autoridades de Uruguaiana, as da cidade vizinha também estiveram na solenidade oficial que legitima o golpe 15 anos após a supressão da democracia. No que se refere a Uruguaiana e Paso de los Libres, está claro o apoio aos regimes ditatoriais e uma suposta simpatia entre autoridades locais importantes de ambos países.

\subsection{Conexões fronteiriças}

O que e quem gerava interesse dos órgãos de controle brasileiros e argentinos nessa fronteira? Em 1973 o Ministério da Aeronáutica enviou uma lista ao Centro de Informações ao Exterior (CIEx) e ao SNI com 14 nomes de pessoas que teriam passado por Paso de los Libres $^{241}$ nesse ano. Na lista, além do nome das pessoas, consta um apanhado de informações de cunho político e pessoal.

\footnotetext{
${ }^{237}$ Em geral este foi o termo utilizado para tratar do golpe de $1964 \mathrm{em}$ todos os jornais locais pesquisados para esta Tese.

${ }^{238}$ O Jornal Ilustrado foi fundado em 1977 e circulava em Uruguaiana e região, não conta com informação acerca da tiragem. Seus diretores eram Alberto Moura e Pedro de los Santos, contava em 1979 com dez colaboradores e um representante em Porto Alegre. Era impresso em São Borja, em 1984 a empresa que representa o jornal recebe uma concessão para transmissão radiofônica.

${ }^{239}$ Festivamente comemorado o $15^{\circ}$ aniversário da Revolução de 1964. Jornal Ilustrado. Uruguaiana, 05 de abril de 1979, ano 2, número 71. Capa.

${ }^{240}$ Ibidem.

${ }^{241}$ ACE_ACE 58818-73. Entrada e saída de brasileiros por Paso de los Libres. Informe 283/CIEx. 11/11/1973. Arquivo Nacional.
} 
Os 14 listados são: Ana Maria Ladeira, Wander Felipe Leal, Rosa Roizen, Ney Roitman, Rejane Maria Carrion, Leocádio de Almeida Antunes, Eduardo Tavares Homem, Isaac Majer Roitman, Heiva Roitman, Nelson Danilevicz, Jarbas Ilgenfritz da Silva, Frederico Mathias Mazzuchelli, José Luiz Viana Gutierrez, Carlos Frederico Mares de Souza. Todos os listados são brasileiros e tinham algum envolvimento político de cunho esquerdista, ou parentesco com envolvidos em "subversão". Ana Maria foi apontada como "agitadora esquerdista"; os Roitman possivelmente seriam parentes de Ary Roitman, que estaria foragido na Argentina; e Leocádio foi identificado no documento como "pombo-correio de Jango". ${ }^{242}$

Esta lista de 1973 demonstra como o controle era intensivo nessa região e o interesse em saber o máximo de detalhes sobre quem "cruzava" o rio Uruguai. Fica explícito que não só quem, efetivamente, tinha algum tipo de atuação em movimentos contrários ao terrorismo de Estado implantado desde 1964 no Brasil, mas também pais, mães, primos, amigos de alguém que tivesse tido alguma passagem pelos órgãos de repressão da ditadura, ou apenas participado de uma reunião e/ou passeata, poderia ser alvo de inverstigação. Assim, também se corrobora que não existia critério estabelecido pela repressão sobre quem poderia ser considerado "subversivo".

Em 1975 foram detidos em Paso de los Libres pela Gendarmeria Nacional Argentina dois professores brasileiros, ambos residentes em Uruguaiana: Bartolomeu Donatila Bonorino Figueiredo e Divino Salvador da Silva. Após a liberação na Argentina, foram chamados pela Polícia Federal no Brasil para dar explicações sobre o ocorrido. Segundo os professores, que voltavam de uma viagem à Buenos Aires, ambos foram detidos e interrogados em Paso de los Libres pois havia suspeita de contrabando em sua bagagem, mas, foram liberados ao apresentar as notas fiscais solicitadas. A Polícia Federal, entretanto, queria saber sobre diversos livros marxistas que supostamente os professores traziam da viagem. Ambos responderam que tinham comprado alguns livros aleatórios em Buenos Aires e que os jogaram no rio Uruguai para evitar problemas no Brasil e que "não pretendiam introduzi-los em nosso país e sim ler os mesmos em Paso de los Libres e depois se desfazerem em território argentino". 243

${ }^{242}$ ACE_ACE 58818-73. Entrada e saída de brasileiros por Paso de los Libres. Informe 283/CIEx. 11/11/1973. Arquivo Nacional.

${ }^{243}$ APA_ACE 7108_84. Professores detidos em Paso de los Libres. Porto Alegre, 26/11/1975. Ministério da Justiça Departamento de Polícia Federal Superintendência Regional no Rio Grande do Sul. Arquivo Nacional. 
É sobejamente conhecida a preocupação de governos ditatoriais com a difusão de livros, principalmente os considerados prejudiciais ao sistema imposto. Os livros que os professores Bartolomeu e Divino jogaram no rio eram todos marxistas - nenhuma novidade ou ineditismo nessa informação no documento da Polícia Federal. O que precisa ser extraído é o que não está explícito no documento.

Dizem os professores que foram detidos por autoridades argentinas por conta de suspeita de contrabando; sabe-se, por sua vez, que livros não eram considerados contrabando, que se exijia nota fiscal na aduana, ou ao menos não era essa a praxe no lado argentino, o que não impedia de ser empecilho e motivo para alguém ser interrogado.

O relatório da Polícia Federal não trata do suposto contrabando, mas sim dos livros, colocando detalhadamente quais as obras estavam com os brasileiros quando foram detidos. Isso deixa evidente que a Polícia Federal recebeu esta informação da Gendarmeria Argentina, e não apenas sobre mercadorias:

Inquiridos sobre a coleção 'Pequena biblioteca Marxista Leninista' composta dos
livros: La Sociedad Comunista, Lucha Sindical y Lucha Politica, Revista Marxista
Latina Americana, Diário del CHE, El Proceso de Camiri, um livro sobre Mao Tse
Tung, Los Judios e Mil Luchas, além de alguns livros técnicos que foram
encontrados em seu poder quando da sua detenção [grifo da autora].

Esta passagem demonstra a troca de informações entre os órgãos de segurança e repressão de ambos os países. Conforme o relato no documento, os professores jogaram os livros no rio depois que foram inquiridos pela Gendarmeria que não confiscou as obras. Se os livros foram jogados no rio antes do interrogatório no Brasil, de que forma a Polícia Federal tinha a lista das obras? O não dito nos documentos produzidos pela repressão nos oferecem a evidência. Houve um primeiro depoimento na Argentina, ainda na aduana. Os professores foram liberados com todas as suas compras, inclusive os livros, assim que deixaram a sala de interrogatório os jogaram no rio. O que se entende é de que as obras foram listadas pelos agentes argentinos e esta informação foi transmitida para a Polícia Federal.

Por motivos evidentes, livros eram trazidos da Argentina rotineiramente, pois a maior diversidade de publicações no idioma espanhol e a censura da ditadura brasileira faziam da Argentina um ótimo local para adquirir literatura de esquerda. Em 1977, Ruy Barbosa de Andrade Bizarro foi preso pela Polícia Federal em Uruguaiana com diversos livros que seriam distribuídos em Porto Alegre - era um conhecido vendedor de livros e costumava fazer muitas

244 APA_ACE 7108_84. Professores detidos em Paso de los Libres. Porto Alegre, 26/11/1975. Ministério da Justiça Departamento de Polícia Federal Superintendência Regional no Rio Grande do Sul. Arquivo Nacional. 
viagens para Buenos Aires para atender pedidos de Porto Alegre, tanto de livrarias como de pessoas físicas.

O relatório da Polícia Federal sobre a sua prisão tem cinco páginas e detalha todos os livros que estavam com ele, bem como endereços de supostos clientes. Ruy foi preso em 30 de abril de 1977 no Hotel Centenário, pela Polícia Federal de Uruguaiana. Na primeira página do documento acerca desse episódio é informado que nesse caso também houve participação das autoridades do país vizinho, porém dessa vez de forma explícita: "2 - Posteriormente, em Paso de los Libres, as autoridades Argentinas efetuaram a apreensão de muitos livros de caráter político esquerdista que foram deixados pelo nominado [Ruy Barbosa de Andrade Bizarro] no Hotel Uruguai" ${ }^{245}$. Ao que consta no documento citado acima, a participação da Argentina foi apenas de recolher os livros que Ruy teria deixado em um hotel em Paso de los Libres; a DPF não esclarece, na documentação pesquisada, como essa ajuda aconteceu.

Como se davam efetivamente as conexões repressivas, ou no jargão militar, colaborações institucionais visando a segurança nacional, seus contatos e modus operandi, não estariam determinadas documentalmente, uma vez que tais documentos, mesmo sendo de cunho confidencial, circulavam em mais de um órgão da repressão. Importa que, mais uma vez, esse relatório explicita a colaboração entre as instituições de segurança do Brasil e da Argentina nessa fronteira. ${ }^{246}$

\subsubsection{Fugas, prisões e conexões fronteiriças}

A fronteira Uruguaiana-Paso de los Libres era vigiada, servia de rota de fuga, e foi cenário de operações repressivas antes da Argentina sofrer o golpe em 1976 - e mesmo antes da formalização da Operação Condor em 1975. Colaborações na aduana eram corriqueiras, bem como ações de apenas um país. Como qualquer processo histórico, este é complexo e tem suas peculiaridades.

Uma prisão ocorrida em Uruguaiana e que ainda não apresenta evidências de contar com a colaboração das instituições de segurança argentinas foi a de Jacques de Souza Coimbra. O caso de Jacques, porém, descortina como a embaixada brasileira em Buenos Aires atuava, por meio dos seus adidos militares, no combate aos "subversivos" fora do território brasileiro, e reforça o quanto essa região foi importante para a repressão e de como a

\footnotetext{
${ }^{245}$ APA_ACE_6455_83. Ruy Barbosa de Andrade Bizarro. Porto Alegre, 18/05/1977. Ministério da Justiça Departamento de Polícia Federal Superintendência Regional no Rio Grande do Sul. Arquivo Nacional. ${ }^{246}$ Ibidem.
} 
ação neste ponto fronteiriço era articulada no alto escalão de segurança do Brasil e da Argentina. Ese caso não só não foi abordado em trabalhos historiográficos como, também, é ignorado por militantes de esquerda, consultados por esta Tese, que buscam reconstituir o passado repressivo recente.

\subsubsection{Jacques de Souza Coimbra e a rede repressiva}

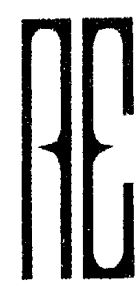

TELEGRAMA RECEBIDO
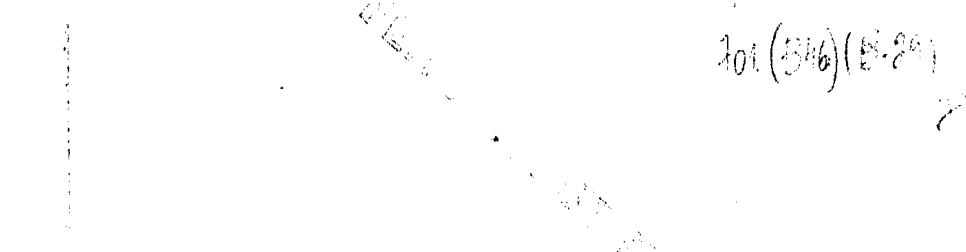

D. BRASELIB baIRES

EN $16 / 5 / 73$

SECRETO

52093

I) $1 /$

JACOUES DE SOUZA COIMBRA.

Deteticho.

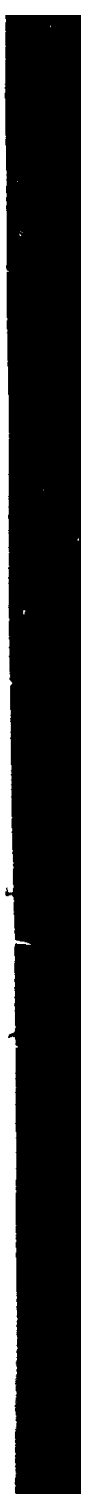

Figura 6 - Telegrama enviado da Embaixada de Buenos Aires para o Brasil.

Fonte: Brasil, MRE (1973).

Nos arquivos da Polícia Política de Minas Gerais, na pasta 0348, que trata da investigação acerca de um movimento guerrilheiro que intencionava fundar a "República das Rosas", Jacques de Souza Coimbra foi apontado como um dos organizadores desse 
movimento, e teria tido como parceiro Valter Cesário Ferreira. Uma reportagem do "Jornal do Brasil" de abril de 1968 aponta os dois como "irresponsáveis que queriam ser Presidente da República e Ministro do Exército da 'República das Rosas",. 247

A "República das Rosas" ou "Rebelião das Rosas" foi noticiada após o roubo de um carro, executado por Jacques e Valter. Amplamente difundida na imprensa, tal guerrilha iniciaria com um ataque à Escola Preparatória de Cadetes do Ar, localizada em BarbacenaMG, e depois ampliaria sua atuação para todo o Estado. Esse ataque não aconteceu, mas foi intensamente divulgado e investigado. Suposições foram divulgadas como a de que guerrilheiros mineiros estariam aliados com guerrilheiros da Bolívia. Jacques deu um depoimento longo para a polícia e afirmou organizar reuniões de cunho político para debater questões brasileiras, além de contar também do plano de ataque na Escola de Cadetes do Ar.

Desse episódio começou uma especulação da imprensa de que havia um grupo guerrilheiro armado em Barbacena-MG. No entanto, os documentos mostram que os militares duvidavam tanto do ataque quanto da existência de grupos guerrilheiros na região. No final, por falta de provas, o inquérito acerca da 'República das Rosas' foi arquivado. Também se difundiu que Jacques e Valter teriam inventado essa história para comprometer estudantes, filhos de pessoas respeitadas da sociedade mineira. Os dois foram tidos como jovens inconsequentes e com possíveis problemas psíquicos. Nada disso, porém, foi comprovado ou adensado naquele momento pelas autoridades. ${ }^{248}$

Apesar de absolvido, Jacques de Souza Coimbra foi monitorado; ao que consta, logo após esse episódio em Minas Gerais saiu do Brasil e foi viver no Chile, de lá foi para Buenos Aires e acabou preso em Uruguaiana-RS. A trajetória da prisão de Coimbra, segundo consta nos documentos do Ministério das Relações Exteriores do Brasil (MRE), é cheia de lacunas e com diversos pontos discutíveis.

Foram três telegramas enviados para o Brasil relatando o caso, e somente um foi respondido. No primeiro consta, "O Consulado-Geral do Brasil nesta capital comunicou-me que pediu repatriação o cidadão brasileiro Jacques Coimbra que registraria antecedentes por delitos contra a segurança e que recentemente teria entrado na Argentina proveniente do

${ }^{247}$ Jornal do Brasil. Jovens queriam assaltar escola e fundar "República das Rosas" em Barbacena. 05 de abril de 1968. Arquivos da Polícia Política acervo do periodo 1927 a 1982. Pasta 0348. Rolo 022. Documento 05. Acervo: Arquivo Público Mineiro (APM). Disponível em: http://www.siaapm.cultura.mg.gov.br/modules/dops_docs/photo.php?numero=0348\&imagem=346.

${ }^{248}$ Arquivos da Polícia Política acervo do periodo 1927 a 1982. Movimento guerrilheiro março - abril de 1968. Pasta 0348. Rolo 022. Documento 05. Acervo: Arquivo Público Mineiro (APM). Disponível em: http://www.siaapm.cultura.mg.gov.br/modules/dops/brtacervo.php?cid=0348. 
Chile"249. Os seguintes são um resumo do que, supostamente, aconteceu com Coimbra entre março e maio de 1973.

Segundo os relatos enviados pela Embaixada brasileira, enquanto esperava a resposta do pedido de repatriação Jacques procurou o coronel Ramos de Castro, adido do Exército na Embaixada do Brasil em Buenos Aires, cidade em que estava vivendo com sua esposa e cinco filhos e onde estaria passando por dificuldades financeiras, a ponto de querer ajuda para voltar ao Brasil. Teria dito que viveu no Chile com sua família e manteve contatos com esquerdistas brasileiros, porém não conseguiu emprego e não era bem recebido pelos esquerdistas de sua nacionalidade, pois era considerado suspeito. Por esses dois motivos, tentou voltar ao Brasil com ajuda da Embaixada brasileira, mas sua saída não foi autorizada. Consta no relato que durante sua visita consular o adido do Exército teria the oferecido dinheiro em troca de informações sobre outros brasileiros que estavam residindo no Chile. Jacques não aceitou a proposta do militar do Brasil - e não cita seu nome - pois estava "queimado" com os companheiros. Teve autorização para viajar para Buenos Aires e queria ajuda para voltar ao Brasil. A demora na resposta estava preocupando Coimbra, pois já não tinha mais dinheiro e contraiu dívidas na cidade.

Nesse encontro com o adido do Exército, já em Buenos Aires, Coimbra, conforme documento da Embaixada brasileira, disse que foi procurado por um homem chamado Major Celso, funcionário do SNI, que lhe ofereceu uma mesada de U\$ 200,00 em troca de informações - nesse caso, sobre as relações das esquerdas do Chile e Argentina e também sobre o trânsito de brasileiros na Argentina. Para efetivar esse acordo, deveria atender uma pessoa chamada Paulo César. Tiveram um encontro, e Jacques foi aconselhado mudar de hotel para não ser localizado - recebeu essa informação e U\$ 500,00. A ordem era de que não voltasse mais ao Consulado, porém por ter considerado essa quantia insuficiente para suas despesas e sem outro contato com Paulo, Jacques resolver pedir novamente ajuda consular e relatar o que havia ocorrido. "Consultei o Coronel Castro sobre se Coimbra havia sido contatado por pessoa ligada aos serviços de segurança brasileiros e recebi resposta negativa. A presença do Senhor Coimbra na Argentina é motivo de sérias preocupações" ${ }^{250}$. Essas informações estão nos telegramas enviados ao Brasil, e não há registro sobre o pedido de repatriação feito em março de 1973. Consta que:

\footnotetext{
249 BRASIL. Ministério das Relações Exteriores (MRE). Pedido de repatriação. Jacques Coimbra. Telegramas recebidos da Embaixada em Buenos Aires 1973. 08/03/1973. Acervo MRE.

${ }^{250}$ Ibidem.
} 
[...] encaminhei-o ao Consulado-Geral de comum acordo com o Coronel Castro, para que lhe sejam fornecidas passagens para regressar o mais breve possível ao Brasil, bem como a quantia necessária para pagar suas dívidas. O Consulado-Geral tomou as providências necessárias e amanhã [palavra não legível] partirá às 17 horas para Porto Alegre, em ônibus da empresa Porto Alegre-Brasília, via Paso de los Libres e Uruguaiana. $O$ adido do Exército comunicou as autoridades competentes todos os dados referentes a chegada do Sr. Coimbra para que sejam tomadas as providências cabíveis [grifo da autora]. ${ }^{251}$

O telegrama seguinte afirma que Jacques embarcou conforme previsto e que foi acompanhado de um funcionário da Embaixada. A pedido do Coronel Castro, esse funcionário levou fotos de "suspeitos". Coimbra, então identificou Major Celso e Paulo César, o primeiro seria um "banido" Plínio Petersen Ferreira, e Paulo César "elemento que mantém contatos com grupos subversivos brasileiros no Chile cuja atuação está sendo investigada". 252

Data de 16 de maio de 1973 o telegrama que abre este item da Tese e dá conta de informar que Jacques de Souza Coimbra foi preso em Uruguaiana e encaminhado para Porto Alegre para ser interrogado. Dois dias antes a Embaixada em Buenos Aires recebeu um telegrama da Secretaria de Estado das Relações Exteriores que informa,

\footnotetext{
Segundo acabo de ser informado pelo CIE, à falta de dispositivo para detectá-lo em viagem o terrorista JACQUES DE SOUZA COIMBRA só foi detido, pela Aeronáutica, em Barbacena, na semana passada [por volta de 08 de maio de 1973]. Declarou ter sido forçado a reconhecer em fotografias os terroristas PLÍNIO PETERSEN PEREIRA e ADILSON PINHEIRO PIMENTEL, e que na verdade não manteve contato algum em Buenos Aires. Para tranquilidade de Vossa Excelência, o referido elemento mostra sinais de agravamento de estado anterior de desequilíbrio mental, já não oferecendo maior perigo ${ }^{253}$ [grifo da autora].
}

As informações são contraditórias quando em 16 de maio a Embaixada brasileira afirma que Jacques foi preso em Uruguaiana. Em 14 de maio, a Secretaria de Estado das Relações Exteriores comunica que ele só foi preso em Minas Gerais, e ainda informa que ele não teve contato algum em Buenos Aires. A esposa e os cinco filhos de Jacques, viajaram? Se viajaram, como viajaram? Que dispositivo faltou em Uruguaiana para detectá-lo? Jacques de fato teria distúrbios mentais e "inventou" tudo? Esse parecer de transtorno mental se assemelha com a conclusão do inquérito de 1968, que ao final aponta como "invenção" o depoimento sobre a "República das Rosas".

251 BRASIL. Ministério das Relações Exteriores (MRE). Pedido de repatriação. Jacques Coimbra. Telegramas recebidos da Embaixada em Buenos Aires 1973. 08/03/1973. Acervo MRE.

252 Ibidem.

${ }^{253}$ Idem. 
Vale ressaltar que os nomes nesses telegramas merecem análise. Os telegramas acessados no arquivo do Ministério das Relações exteriores do Brasil são do acervo "secreto". Essa categoria de documento dificilmente seria encaminhada sem conhecimento do Embaixador, que na época era Antônio Francisco Azeredo da Silveira. Sua atuação em Buenos Aires foi de 1969 até 1974, quando sob o governo de Geisel assumiu o Ministério das Relações Exteriores. Permaneceu cinco anos como ministro e é considerado um dos mais influentes diplomatas que assumiu o posto. Azeredo faleceu em 1990 e deixou um considerável acervo pessoal de documentos. Atualmente seu arquivo está sob custódia do Centro de Pesquisa e Documentação de História Contemporânea do Brasil da Fundação Getúlio Vargas (CPDOC/FGV). A série "Embaixador na Argentina” é composta de seis dossiês, sendo que o mais significativo trata dos recursos naturais da Bacia do Prata, seguido por relatórios referentes a política interna e externa da Argentina. Durante pesquisa no MRE, de fato, a maioria dos telegramas tratava desses dois temas. Um livro foi publicado com base em depoimentos gravados entre 1979 e 1982, obra intitulada "Azeredo da Silveira um depoimento" 254 .

O adido do Exército citado nos telegramas, coronel Sebastião José Ramos de Castro foi apontado no relatório final da Comissão Nacional da Verdade na lista de:

São identificados como autores, neste capítulo, os autores materiais, que cometeram ou participaram, pessoal e diretamente, dos casos de tortura, morte, desaparecimento forçado e ocultação de cadáver, bem como os autores intelectuais, idealizadores e mandantes de tais violações. ${ }^{255}$

O coronel está citado no eixo "C" do relatório: responsabilidade pela autoria direta de condutas que ocasionaram graves violações de direitos humanos - não pelo caso de Jacques Coimbra, mas sim por outras quatros vítimas da ditadura brasileira:

364) Sebastião José Ramos de Castro

(1922-) General de exército. Adido do Exército na Embaixada do Brasil em Buenos Aires, de março de 1971 a fevereiro de 1973. Teve participação no sequestro e desaparecimento forçado de Edmur Péricles Camargo, em Buenos Aires, em 16 de junho de 1971. Em 1973, após voltar de Buenos Aires, passou a servir no Serviço Nacional de Informações (SNI), primeiro como assessor da direção do órgão, depois, por quase quatro anos, como chefe da agência central, tendo sido exonerado do cargo em 1978. No SNI, teve também participação no caso do sequestro dos cidadãos paraguaios Aníbal Abbate Soley, Alejandro Stumpfs e Rodolfo Mongelos, ocorrido em Foz do Iguaçu em dezembro de 1974. Vítimas relacionadas: Edmur

\footnotetext{
${ }^{254}$ Sobre esse livro mais informações no site da obra: http://silveiradepoimento.com.br/site/

${ }^{255}$ BRASIL. Comissão Nacional da Verdade. Relatório/Comissão Nacional da Verdade. - Brasília: CNV, 2014. Volume I. Tomo II. Parte IV Dinâmica das graves violações de direitos humanos: Casos emblemáticos, locais e autores. O Judiciário. Capítulo 16. A autoria das graves violações de Direitos Humanos. p. 873.
} 
Péricles Camargo (1971); Aníbal Abbate Soley, Alejandro Stumpfs e Rodolfo Mongelos (1974). ${ }^{256}$

Sobre os "suspeitos" Plínio Petersen Pereira e Adilson Pinheiro Pimentel, o primeiro foi militante do Movimento Revolucionário Tiradentes (MRT), participava da luta armada. No Arquivo da Polícia Política, um documento da Secretaria de Estado da Segurança Pública de Minas Gerais pede a localização e prisão de Plínio em maio de 1971, classificando-o como terrorista, e informando que em 1964 Plínio, também conhecido como "Gaúcho" ou "Marcos”, exilou-se no México e voltou ao Brasil pelo Uruguai. Sua esposa em 1971 estaria residindo em Porto Alegre-RS. No livro “Orvil - Tentativas de tomada de poder”, Plínio é citado como participante de diversas operações armadas, entre elas o sequestro de Nobuo Okuchi, Cônsul Geral do Japão em São Paulo, ocorrido em março de 1970 em ação conjunta entre o MRT e Vanguarda Popular Revolucionária (VPR). Na biografia "Pedro e os Lobos: os anos de chumbo na trajetória de um guerrilheiro urbano" consta a participação de Plínio nesse sequestro, que ocorreu para troca de presos. Sobre Plínio ter vivido em Buenos Aires nada consta nesses documentos e na bibliografia consultada. ${ }^{257}$

Já Adilson Pinheiro Pimentel foi preso acusado de "pretender" dar um tiro em Castelo Branco, durante um evento em memória das vítimas militares da Intentona Comunista de 1935, realizado no Cemitério São João Batista no Rio de Janeiro em 27 de novembro de 1965: "De repente um homem rompeu o cordão de isolamento supostamente pretendendo dar um tiro no presidente. Foi preso e levado para a Polícia do Exército" ${ }^{\text {258 }}$. Nesse trecho, uma nota aponta que o homem se chama Adilson Pinheiro Pimentel, um aeroviário, que seria internado para realizar exames de sanidade mental, porém fugiu do Hospital do Exército e exilou-se no Uruguai. ${ }^{259}$ Nos arquivos do Arquivo Público Mineiro consta um documento sobre Adilson, em que ele integra uma lista de pedido de detenção junto com Carlos Marighela e outros sete

\footnotetext{
${ }^{256}$ BRASIL. Comissão Nacional da Verdade. Relatório/Comissão Nacional da Verdade. - Brasília: CNV, 2014. Volume I. Tomo II. Parte IV Dinâmica das graves violações de direitos humanos: Casos emblemáticos, locais e autores. O Judiciário. Capítulo 16. A autoria das graves violações de Direitos Humanos. p. 928.

${ }^{257}$ Arquivos da Polícia Política acervo do período 1927 a 1982. Presos Políticos. Agosto 1969 - Novembro de 1971. Pasta 0060. Rolo 006. Documento 238 e 239. Acervo: Arquivo Público Mineiro (APM). LAQUE, João Roberto. Pedro e os lobos: os anos de chumbo na trajetória de um guerrilheiro urbano. Vega Editora Ltda. 2010. "Orvil - Tentativas de tomada de poder" disponível em: http://www.averdadesufocada.com/images/orvil/orvil_completo.pdf

258 TÉRCIO, Jason. A espada e a balança: crime e política no banco dos réus. Rio de Janeiro: Jorge Zahar Editor, 2002.p. 67.

${ }^{259}$ Ibidem.
} 
cidadãos. Esse pedido foi feito pelo Departamento de Polícia Federal - Delegacia Regional de Minas Gerais para o Secretário de Segurança Pública de Minas Gerais ${ }^{260}$.

Dito isso, importa ressaltar do caso de Jacques Coimbra e os envolvidos na documentação acerca dele, o funcionamento do sistema de monitoramento e logística repressivo da época. Jacques e os demais tinham a maioria dos seus passos monitorados, independente do país onde estivessem. Também importa ressaltar a importância dos detalhes nesse emaranhando de fatos; entre outras coisas, destaca-se a questão da prisão de Jacques ter duas ocorrências diferentes, algo que chama a atenção. Segundo as informações de Buenos Aires, ela ocorreu em Uruguaiana-RS, mas conforme os registros do Ministério das Relações Exteriores a prisão foi em Minas Gerais, devido à falta de "dispositivo para detectá-lo". Essa afirmação é estranha, visto que se entende por "dispositivo para detectá-lo" funcionários da repressão que pudessem identificá-lo e/ou prendê-lo. O que aconteceu para que Jacques não fosse preso em Uruguaiana? Convém apontar que tanto Jacques como Adilson foram "diagnosticados" com problemas mentais. Isso era comum à época, para desacreditar depoentes que denunciavam graves violações aos direitos humanos ocorridas sistematicamente.

A rede que está atrelada ao caso Jacques contribui para esclarecer a logística repressiva do Cone Sul quanto às trocas de informações. As ações dos opositores eram acompanhadas e compartilhadas entre os órgãos de repressão. Desde as delegacias de polícia estaduais, passando pelos serviços de informação militares até o Itamaraty. Nesse ponto também cabe ressaltar que os funcionários deslocados para Buenos Aires eram experientes em suas áreas, como o caso do Embaixador Azeredo e do Coronel Ramos, o primeiro assumindo o MRE após sua passagem pela Argentina e o segundo apontado, no relatório da CNV, como responsável por graves violações ao direitos humanos. Esse episódio, portanto, demonstra efetivamente que a fronteira Uruguaiana-Paso de los Libres era ponto importante para a logística repressiva das ditaduras de segurança nacional, bem como desvela um caso inédito na historiografia e os diversos órgãos que trocavam informações acerca de "subversivos". Não há um documento final, no cotidiano dos pesquisadores de períodos de repressão no Brasil, e com mais dificuldade para quem busca reconstruir as conexões estabelecidas no Cone Sul, faz parte do método de pesquisa, a análise de um número significativo de documentos, para

${ }^{260}$ Arquivos da Polícia Política acervo do período 1927 a 1982. Documentações e comunicações diversas sobre presos políticos. Dezembro de 1968 - Abril de 1970. Pasta 0058. Rolo 006. Documento 329. 03/07/1969. Acervo: Arquivo Público Mineiro (APM). 
encontrar pequenos vestígios. Esses juntos, dão sentido ao processo em análise, como no caso acima retratado.

\subsubsection{Cônsul Ney Corrêa: ocorrências pontuais na aduana}

O consulado brasileiro em Paso de los Libres, durante a ditadura civil-militar, foi designado como privativo; estava subordinado ao Consulado Geral de Buenos Aires. Dentre as atividades cotidianas, durante a repressão, estava o monitoramento sistemático de opositores, assim como receber e enviar informações para Buenos Aires. O cônsul Ney Floriano de Faria Corrêa atuou mais de uma vez intercedendo em trâmites aduaneiros de pessoas que saiam da Argentina.

Os "consulados privativos" não foram criados pelo governo militar; esse modelo é de 1930, quando o Presidente Getúlio Vargas assinou o Decreto n ${ }^{\circ} 19.466$ de 6 de dezembro, que instituía consulados privativos em cidades de fronteira:

\footnotetext{
Considerando a necessidade de manter em certos postos de fronteira do sul do país funcionários que estejam familiarizadas com o meio;

Considerando, também, a utilidade de que tais funcionários sejam, na medida do possível; inamovíveis, para que melhor possam prestar nesses postos os serviços que deles espera o Governo;

Considerando, ainda; que, no quadro atual dos funcionários consulares, poucos são os que preenchem esses requisitos;

DECRETA:

Art. $1^{\circ}$ Ficam criados consulados privativos nas cidades de Alvear, Artigas, Bela União, Melo, Paso de los Libres, Paissandú, Posadas, Rio Branco, Rivera e Santo Tomé.

Art. $2^{\circ}$ Serão nomeados, em comissão, para esses postos, no carater de cônsules privativos, brasileiros idôneos e que não pertençam ao quadro do Corpo Consular.

Art. $3^{\circ}$ Tais funcionários formarão um quadro à parte, não lhes sendo aplicaveis as normas regulamentares em matéria de ajudas de custo, férias extraordinárias, promoção, disponibilidade e aposentadoria.

Art. $4^{\circ} \mathrm{A}$ remoção dos consulados privativos só poderá ser feita para consulados dessa espécie. ${ }^{261}$
}

Em 26 de outubro de 1964 o Decreto $\mathrm{N}^{\mathrm{o}} 54.578$ revogou o anterior e o consulado voltou ser de carreira. Dois anos depois, em 1966, o Decreto № 1018 torna-se privativo, e a revogação só aconteceu em 1993. Enquanto consulado privativo o cônsul não era um diplomata de carreira, mas alguém que fosse considerado adequado para os "interesses do governo" no local. Ney Floriano de Faria Corrêa, graduado em ciências sociais e jurídicas e

261 BRASIL. Presidência da República. Decreto No 14.666 de 06 de Dezembro de 1930. Disponível em: http://www2.camara.leg.br/legin/fed/decret/1930-1939/decreto-19466-6-dezembro-1930-561324publicacaooriginal-84927-pe.html 
formado na Escola Superior de Guerra, foi indicado para ocupar o consulado brasileiro em Paso de los Libres.

Um dossiê de 1976 apresenta dois casos com a atuação direta de Ney. Em janeiro desse ano dois homens foram encaminhados até ele por um funcionário da Gendarmeria Argentina. O cônsul privativo os levou até o agente de plantão na Delegacia de Polícia Federal (na aduana). Os dois estavam a caminho de São Paulo e se apresentaram como pertencentes aos serviços de informações da Argentina. Viajavam de carro, que deixaram em uma garagem em Uruguaiana. Ambos seguiriam para Porto Alegre de ônibus. Não é usual que o cônsul, diretamente, encaminhe pessoas para os trâmites de fronteira.

Provavelmente, esses homens estavam sendo monitorados, apesar de não constar nenhuma informação que justifique a motivação da produção de um relatório tão denso. $\mathrm{O}$ dossiê sobre esse caso conta com documentos de unidades da Polícia Federal do Rio Grande do Sul, de Fortaleza e do Maranhão; do III Comando do Exército; da Secretaria de Segurança Pública do Rio Grande do Sul; e do Serviço Nacional de Informações. Ademais de toda a pesquisa executada nas instituições de segurança e informação, no final de 1976 o cônsul privativo também foi investigado, por interceder em trâmites de fronteira. ${ }^{262}$

Os homens apresentaram-se como Alexandre Mario Berar, cidadão argelino/francês com endereço em São Luiz-MA, e Miguel Angel Smutny, argentino, residente em Buenos Aires. Conforme os documentos desse dossiê, Alexandre afirmou que viajou para a Argentina, saindo de São Paulo no começo de janeiro de 1975. Para essa viagem ele afirma que não precisou apresentar documento de identificação e também não fez a imigração. Ele foi encontrar com Miguel em Buenos Aires e estavam em viagem com destino final em Porto Alegre.

Com auxílio do cônsul, foram liberados na fronteira de Uruguaiana, deixaram o automóvel que conduziam em uma garagem em Uruguaiana (endereço exato não informado) e voltaram na aduana em 7 de fevereiro de 1976, com intenção de ingressar na Argentina. Sobre os 13 dias que o carro ficou estacionado no Brasil o dossiê não traz informações.

Em fevereiro, ao tentar voltar para a Argentina com Miguel, Alexandre também não apresentou documentação na aduana e por isso foi impedido de seguir viagem. Miguel teria retornado para Buenos Aires no automóvel, e as autoridades brasileiras acreditaram que Alexandre "ludibriou as autoridades novamente"263. Novamente, já que a explicação no

\footnotetext{
262 APA_ACE_3253_81. Alexandre Mario Berar. 02/07/1976. Presidência da República. Serviço Nacional de Informações (SNI) Agência Porto Alegre. Arquivo Nacional.

${ }^{263}$ Ibidem.
} 
relatório para o ingresso sem documento de identificação na Argentina seria que ele "ludibriou" as autoridades brasileiras e argentinas.

As autoridades não informaram se, de fato, Alexandre voltou para a Argentina ou se ficou no Brasil, e não consta que tenha sido preso por falta de documentos. Elas não apresentam motivos para terem liberado Alexandre. Repetindo os termos utilizados pelas autoridades, como permitiram ser "ludibriados" se já estavam desconfiados do cidadão? Certamente Alexandre teve ajuda de alguém, e o relatório sobre sua presença em Uruguaiana é, no mínimo, omisso sobre essas questões. Pelo aferido na pesquisa, a pessoa que ajudou Alexandre, provavelmente foi o cônsul, que auxiliou-o quando chegou com Miguel na fronteira Paso de los Libres - Uruguaiana. O silêncio e as lacunas no caso de Alexandre indicam uma ação secreta em determinados aspectos, como o de ingressar na Argentina sem documentação, para onde se dirigiu quando foi impedido de retornar, e a sua não detenção ou um interrogatório mais apurado. As evidências indicam que ele teve auxílio, e o único nome que aparece ligado à ele é o do cônsul.

O enredo que envolve Alexandre é complexo. Conforme as investigações, o endereço fornecido por ele pertencia a Serge Mario Fabre. Não só o endereço é coincidente entre Alexandre e Fabre, pois:

[...] comparando-se os dados de qualificação de Mario Fabre e Alexandre Mario Berar, verifica-se que são coincidentes as datas e locais de nascimento de ambos, bem como, o número de registro de identidade para estrangeiro, $\mathrm{RE} \mathrm{n}^{\mathrm{o}} 1058$. [...] Depreende-se dos itens anteriores, [...] salvo melhor juízo, que Alexandre Mario Berar é o nome falso usado por Serge Mario Fabre. ${ }^{264}$

A partir daí, a investigação passou a ser sobre Serge, até porque segundo o SNI não havia registros de Alexandre, exceto os documentos (um comprovante de residência) que ele apresentou em Uruguaiana, onde constam os mesmos dados de Serge. O dossiê não afirma categoricamente que Alexandre de fato seja Serge, mas aponta fortes evidências. Serge foi casado com Alcione Diaz Nazareth - a cantora Alcione, também conhecida como "Marrom". O casal, junto com Pedro Bezerra Cavalcante Filho, foram sócios da empresa Cocamar Comércio de Camarões Ltda, “que encerrou suas atividades no Maranhão no início de 1975 deixando um péssimo conceito naquela área, resultante de não ter saldado compromissos

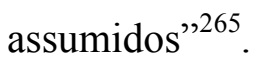

\footnotetext{
${ }^{264}$ APA_ACE_3253_81. Alexandre Mario Berar. 02/07/1976. Presidência da República. Serviço Nacional de Informações (SNI) Agência Porto Alegre. Arquivo Nacional.

265 Ibidem.
} 
Serge Mario Fabre foi preso em setembro de 1999 e extraditado para a França em 2000, com diversas acusações de atividades anteriores a sua passagem pelo Brasil e Argentina: atentados, participação em grupos armados de extrema direita, e tráfico internacional de drogas. Informações publicadas em junho de 2000 dão conta de que Fabre viveu 30 anos no Brasil e detalha suas atividades ilegais. Foi condenado a prisão perpétua na França por participar de crimes políticos. ${ }^{266}$

Já sobre Miguel Angel o dossiê pouco comenta, assim como poucas reportagens sobre ele são encontradas. Ao analisar os dados dos documentos apresentados por ele na aduana quando saiu do Brasil em fevereiro de 1976, o número do Documento Nacional de Identificação que foi citado no dossiê, nos registros argentinos, pertence a uma mulher ${ }^{267}$, enquanto que o nome que ele declarou para as autoridades brasileiras consta em um registro diferente de identificação.

Deste episódio, é preciso refletir que "Alexandre" ou "Serge" tem sua identidade contestada pelas autoridades e uma investigação foi feita. Apesar de todas as evidências que constam no dossiê citado, e do histórico de Serge, não consta que ele esteve envolvido em atividades repressivas ou de oposição ao regime castrense. O mais curioso é que não foi interrogado na ocasião em que esteve diante das autoridades na fronteira.

Consta que Serge sempre teve empresas no Rio de Janeiro, no Amapá e em Belém do Pará; há de se questionar por qual motivo ele não foi inquerido após todo esse episódio conflituoso em Uruguaiana, nem sequer para buscar informações de "Alexandre" - se este existiu ou não, se era Serge ou alguém tentando se passar por ele.

Os procedimentos padrão do agentes de segurança diferem muito do habitual nesse caso. Como já demonstrado na Tese, muitas pessoas eram detidas para averiguações por portar livros "comunistas"; uma pessoa sem documento de identificação, apresentando apenas uma correspondência, conseguiu "ludibriar" as autoridades? O que motivou os agentes não levar adiante investigações sobre Alexandre/Serge? Os mesmos questionamentos se aplicam para o caso de Manuel: a questão do número de seu registro ser diferente do informado, e o fato de estar viajando de Buenos Aires com um francês que estava ilegal na Argentina, não chamaram a atenção de ninguém durante o episódio? Miguel também não foi interrogado, ou

\footnotetext{
${ }^{266}$ STF aprova pedido de extradição de terrorista francês. Diário do Grande ABC. 16/06/2000. Disponível em: http://www.dgabc.com.br/Noticia/313406/stf-aprova-pedido-de-extradicao-de-terrorista-frances

${ }^{267}$ Como se trata de informação pessoal, e a mulher cujo número de DNI condiz com o apresentado por Manuel Angel não é citada em documentos pesquisados, tampouco foi encontrado qualquer vestígio de envolvimento dessa pessoa, com o tema e objeto de estudo desta Tese, optou-se por omitir seu nome.
} 
se foi interrogado seus registros não estão no Arquivo Nacional junto com os demais, principalmente junto ao dossiê sobre o caso.

A participação do cônsul privativo nesse caso é um diferencial, já que ele foi, inclusive, investigado por isso. Ney Floriano Faria de Corrêa foi graduado na Escola Superior de Guerra, segundo o relatório final da CNV, "sabidamente ligado ao SNI"268 e com contatos importantes entre as autoridades do governo. Casado com Alice Faria Corrêa, que esteve envolvida em um dossiê acerca de um pastor muito conhecido em Uruguaiana nos anos 1970 e 1980.

O pastor Orvandil Barbosa foi radialista em Uruguaiana, seu programa tinha grande audiência na cidade, era monitorado pois costumava fazer declarações polêmicas e provocativas ao governo. Em uma ocasião declarou que: "Se Jesus estivesse vivo seria subversivo". Segundo o relatório sobre as atividades do pastor, Alice Faria Corrêa teria declarado em um evento social que concordava com a afirmação do pastor. $O$ casal era vizinho de Orvandil, e não foi confirmado pela repressão a simpatia da esposa do cônsul com essa ou outras declarações do pastor. Ainda em seu relatório - produzido pela Polícia Federal - constam dados sobre o cônsul:

\footnotetext{
"Mantém constantes contatos, oficiais e pessoais, com as autoridades brasileiras em Uruguaiana, inclusive o General Mário Ramos de Alencar, Comandante da $2^{\mathrm{a}}$ Brigada de Cavalaria Motorizada em Uruguaiana.

Segundo suas declarações, mantém contato com elementos do SNI". ${ }^{269}$
}

Ainda em 1976, Ney ajudou com os trâmites de outra pessoa: Adyr Dora Fernandes. Natural de Uruguaiana, Adyr viajava de Buenos Aires para o Rio de Janeiro. Quando chegou em Uruguaiana foi realizar os trâmites de emigração acompanhada pelo cônsul privativo, após a devolução dos documentos pessoais de Adyr, os dois saíram sem passar pela fiscalização brasileira para a apresentação obrigatória de sua bagagem ${ }^{270}$. Não há explicação para essa ocorrência no documento citado - ao que consta, Adyr não estava envolvida com a repressão ou era considerada "subversiva". A partir dos episódios envolvendo as atividades do cônsul, se percebe que ele tinha um comportamento excêntrico em suas atividades profissionais, já que não é função acompanhar pessoas em seus trâmites aduaneiros.

\footnotetext{
${ }^{268}$ BRASIL. Comissão Nacional da Verdade. Relatório/Comissão Nacional da Verdade. - Brasília: CNV, 2014. Volume I. Tomo I. Parte II As estruturas do Estado e as graves violações de direitos humanos. Capítulo 5 A participação do Estado em graves violações de direitos humanos no exterior. p. 193.

269 AC_ACE_93049 76. Orvandil Barbosa (Reverendo em Uruguaiana/RS). Ministério da Justiça Departamento de Polícia Federal. Arquivo Nacional.

270 AC_ACE_103460_76. Dr. Ney Faria Corrêa -Cônsul do Brasil em Paso de los Libres/Argentina. Presidência da República - Serviço Nacional de Informações Agência Porto Alegre. 19/05/1976.
} 
Considerando essas particularidades apontadas e ocorrências diversas em Uruguaiana e Paso de los Libres, a intenção foi mostrar que inúmeras conexões ocorreram nessa fronteira; que o controle é exaustivo de ambos os lados, que esses, quando de interesse comuns efetuam "favores", mesmo que não seja o protocolado pelos Estados. Em casos como o de Ney, que atuava fora de sua alçada profissional, ao menos daquela que se divulga para a sociedade, afere-se que o Estado criou mecanismos distintos e subjetivos para suas instituições. Ao instituir novamente os consulados privativos, há a descaracterização dos critérios estabelecidos pelo Ministério das Relações Exteriores, pois um profissional de carreira é substituído por quem "melhor possa atender os interesses do Estado". Afere-se, portanto, que os interesses do governo brasileiro eram de controlar determinadas zonas e os agentes que nela atuavam. 


\section{ESTRUTURA REPRESSIVA NA FRONTEIRA URUGUAIANA-PASO DE LOS LIBRES}

De fato, o Estado sob a base do TdE tinha um caráter dual, conforme Bobbio, o normativo e o discricionário. O normativo, de Direito, formalmente sob domínio das leis, e o "Estado discricionário" atua com "base em um mero juízo de oportunidade", o qual, no caso em tela, era de atuar livremente, sem atender à legalidade, para destruir o inimigo político. ${ }^{271}$ "La dictadura introdujo un cambio sustancial en la lógica represiva: la desaparición forzada de personas y los centros clandestinos dejaron de ser una de las formas de la represión y pasaron a ser la modalidade represiva por excelencia del poder". ${ }^{272}$ A intenção era aterrorizar a parcela da população que se propunha oposição ao regime imposto. Por meio de atividades secretas, mas que se espalhavam nas parcelas da sociedade que eram alvo da repressão política, o medo funcionava como motor de controle social. Tanto a Argentina quanto o Brasil, guardada as devidas proporções e peculiaridades na implantação do terror, se serviram do medo para controlar os ditos "inimigos" e, dessa forma, ao anular seus opositores, alcançavam a sociedade como um todo, que não seria persuadida por esses grupos.

Dentro da lógica do terror estatal criaram-se as prisões clandestinas, os chamados centros de detenção clandestinos ou "chupaderos". Tamanha era brutalidade e violência praticada nessa prisões que ficaram conhecidas na Argentina como chupaderos pois, além da tortura física e psicológica aplicada, testemunhos de sobreviventes dão conta que nessas prisões seu corpo era dilacerado e sua "alma chupada". Essa alcunha está diretamente ligada à tortura e busca de informação pelo torturador, que buscava "chupar" todas as informações do torturado.

A fronteira Uruguaiana - Paso de los Libres era controlada tanto no aspecto logístico, de conhecimento público, quanto por atividades secretas. Não foi uma logística implementada em todo o território, quer brasileiro ou argentino, mas em locais estratégicos. A fronteira estudada nesta Tese foi uma dessas regiões, em que o Estado agiu de modo normativo e discricionário.

As prisões clandestinas eram lugar de interrogar os prisioneiros, por meio de violência física e psicológica, ao mesmo tempo em que serviam como exemplo para a manutenção do regime. Na Argentina, logo após o golpe a quantidade de sequestros e desaparecimentos foi ampliada significativamente, muitos realizados durante o dia. Dessa forma, os grupos de

\footnotetext{
${ }^{271}$ BOBBIO, Norberto. Democracia e segredo. 1. ed. São Paulo: Editora Unesp, 2015. p. 9.

${ }^{272}$ GARAÑO, Santiago; PERTOT, Werner. Detenidos-aparecidos. 1. ed. Buenos Aires: Biblos, 2007. p. 25.
} 
oposição tornavam-se cientes de que o governo agia de forma dual, já que as informações sobre os desaparecidos se reverberavam entre a militância.

Diante desta realidade, as ações só eram secretas do ponto de vista legal, pois com a quantidade significativa de desaparecimentos era impossível esconder tais atividades. Um exemplo invisível: o campo, a tortura e os desaparecidos são a presentificação da ausência. Sobre essa lógica: "El eje del mecanismo desaparecedor era obtener la información necesaria para multiplicar las desapariciones hasta acabar con 'el enemigo' [...]. En consecuencia, la tortura era la clave, el eje sobre el que giraba toda la vida del campo". 273

A tríade do terror - sequestro, tortura e desaparecimento - foi a metodologia criminal utilizada pelos Estados sob intervenção militar nos anos 1970. Com base na Doutrina de Segurança Nacional e tendo como eixo uma comunidade repressiva, composta na Argentina pelo Servicio de Informaciones del Estado (SIDE) e no Brasil pelo SNI - que reunia as informações de todos os outros órgãos de segurança do país e, com a articulação das ditaduras do Cone Sul, a centralização esquematizada pela DINA no Chile -, as informações e a tríade do terror se fizeram presentes em todo o território. Dessa forma, uma perseguição sem precedentes se articulou no Cone Sul. Esta Tese percebe as prisões clandestinas como um dos pilares mais significativos do terror de Estado, visto que esses locais operacionalizavam a teoria que amparava essas ditaduras - por meio da tortura, conseguiam informações acerca do “inimigo", e depois desapareciam com os corpos; se não tem corpo, não há crime?! As prisões serviam, efetivamente, para obter informação através de tortura, eliminar os "inimigos" e disseminar o terror nos opositores por meio dos desaparecimentos. Essa é a chave analítica usada para compreender o processo histórico dos casos tratados na Tese, ou seja, para além da questão da violência em si, ou como mote de entendimento. Uma abordagem que contempla a questão das articulações e conexões com fins de manutenção de um poder autoritário e terrorista, que alicerça essa manutenção por meio dos desaparecidos, ou seja, quando os “ausentes se tornam presentes" 274 é que o Terrorismo de Estado se consolida.

É na conjuntura de TdE que os casos analisados nessa Tese estão inseridos, frutos de operações binacionais realizadas em um local pensado e preparado para tais ocorrências. A estrutura repressiva presente em Paso de los Libres e Uruguaiana é a reverberação da implantação paulatina de uma logística de terror estatal, desde a definição das fronteiras como áreas sensíveis ao tema segurança até a prática de sequestros clandestinos, em que agentes de

273 CALVEIRO, Pilar. Poder y desaparición: los campos de concentración en Argentina. 1. ed. 6. reimp. Buenos Aires: Colihue, 2008. p. 61.

${ }^{274}$ SARLO, Beatriz. Tempo presente: notas sobre a mudança de uma cultura. Rio de Janeiro: José Olympio, 2005. 
ambos os países atuavam juntos. Esse capítulo tem como objetivo auxiliar o entendimento dessas conexões repressivas binacionais, tratando das prisões clandestinas e "inimigos": as prisões clandestinas como prática do terror e clandestinidade do Estado, e os "inimigos" enquanto grupos que eram foco, no período e região estudada, de busca e detenção clandestina.

\subsection{A prisão clandestina e o trânsito de "inimigos"}

Paso de los Libres e Uruguaiana contavam com um aparato de segurança bem estruturado e com considerável número de agentes, tanto no âmbito militar quanto no civil. “Una frase local resume la situación: 'Acá hay más milicos que gente' dicen los pobladores del lugar para dar cuenta de la massiva presencia militar". ${ }^{275}$

Além de unidades militares e agências de polícias (Polícia Federal e Gendarmeria Nacional), nessa região estava localizado um centro clandestino de detenção. A existência de um local como esse é a síntese da repressão inédita que ocorreu nos anos 1970 nessa fronteira. A região estava sobrepujada tanto no aspecto normativo quanto no secreto da repressão.

A Argentina implementou durante os anos 1970 entre 340 e 400 centros de detenção clandestinos; das 23 províncias argentinas, ao menos 11 contaram com esse tipo de prisão, localizadas estrategicamente e cada uma com características próprias, "Cada cárcel dependió de su posición dentro de un sistema global de represión nacional, lo suficientemente flexible como para adaptarse a la trama de relaciones de poder" ${ }^{276} \mathrm{O}$ número de prisões não é exato, assim como o de desaparecidos, pois para que se determine um local como centro de detenção clandestino é preciso que haja uma denúncia, e nem sempre existem sobreviventes ou outras testemunhas para denunciar - assim como muitos sobreviventes não denunciaram sua detenção. A CONADEP recebeu 8.960 denúncias, mas o número estimado de pessoas que passaram pelas prisões, segundo diferentes organizações de direitos humanos é de 15 mil à 20 mil pessoas. E o número de desaparecidos na Argentina é estimado em 30 mil pessoas, conforme diversas organizações de direitos humanos. No Brasil, oficialmente tem-se número por volta de 500 mortos/desaparecidos, porém com a difusão das comissões e comitês pela verdade, esse número será ampliado. Somente no caso da Guerrilha do Araguaia que até então contabilizava 69 mortos/desaparecidos, atualmente se projeta que esse número seja de mais de

\footnotetext{
${ }^{275}$ GRIMSON, A. La nación en sus límites - Contrabandistas y exilados en la frontera Argentina-Brasil. Barcelona: Editorial Gedisa S/A, 2003. p. 187.

${ }^{276}$ GARAÑO, Santiago; PERTOT, Werner. Detenidos-aparecidos. 1. ed. Buenos Aires: Biblos, 2007. p. 27.
} 
360. Bem como o número de camponeses e indígenas, que até o momento não estão nas listas oficias do Estado. ${ }^{277}$

\subsubsection{La Polaca, la chacra}

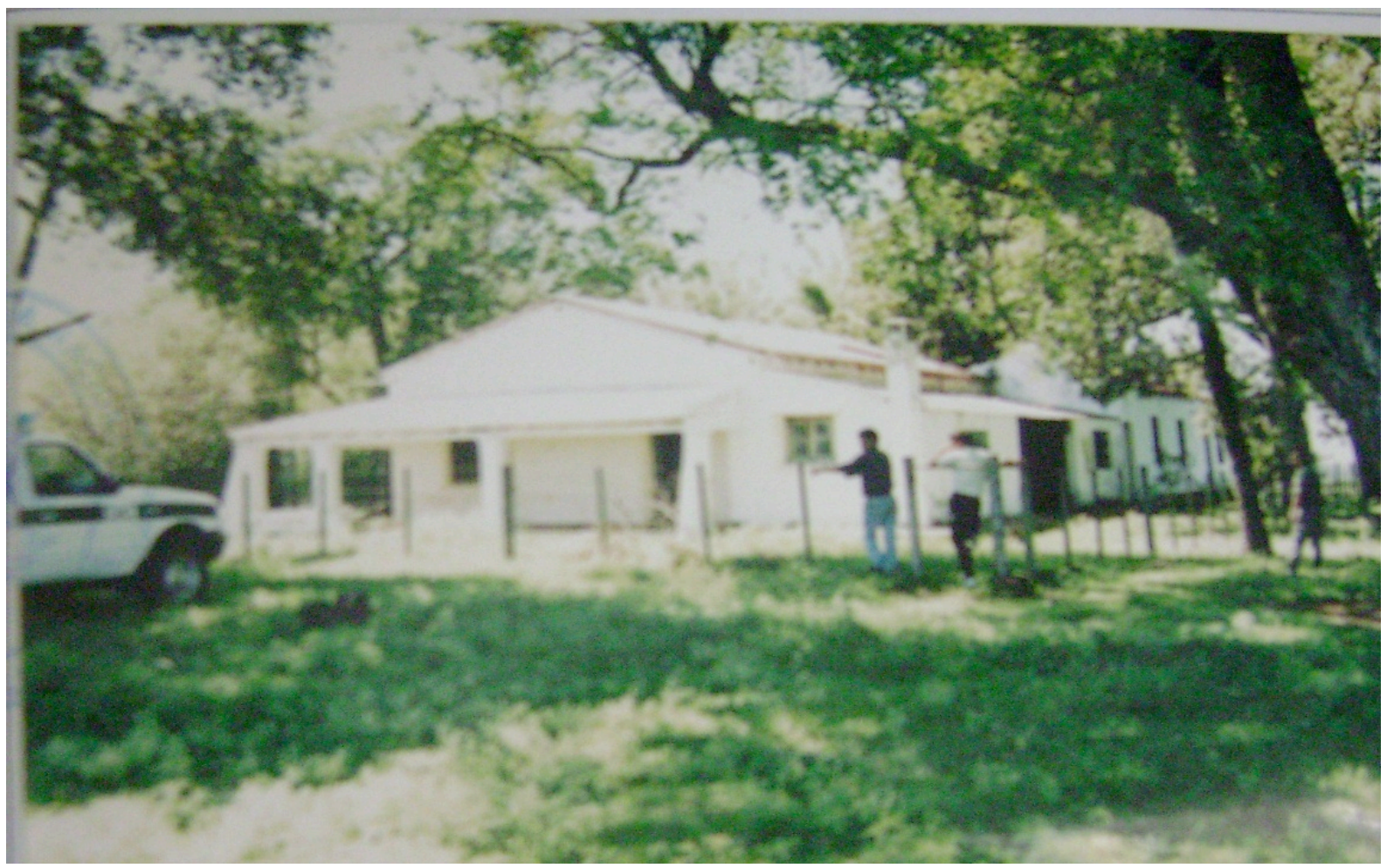

Figura 7 - Vista da casa principal da estância La Polaca, Juzgado Federal argentino, 15 de novembro de 2004. Fonte: Juzgado Federal de Paso de los Libres (2004).

As prisões clandestinas faziam parte do esquema repressivo organizado sistematicamente pelos militares, e foram chave na implementação do terror de Estado: "los centros de detención [...] constituyeron el presupuesto material indispensable de la política de desaparición de personas" ${ }^{278}$. A responsabilidade pelos “chupaderos" era do Batalhão 601 (B601). Em Paso de los Libres funcionava o Destacamento 123 (D123), unidade militar subordinada ao B601. Conforme Mariano:

\footnotetext{
${ }^{277} \mathrm{Na}$ Comissão de Anistia do Ministério da Justiça encontram-se por volta de 360 pedidos de anistia acerca de mortos/desaparecidos na Guerrilha do Araguaia. O número de camponeses mortos/desaparecidos, conforme a Comissão Camponesa da Verdade é de 1.196, relatório disponível em: http://www.mpabrasil.org.br/biblioteca/livros/relatorio-final-comissao-camponesa-da-verdade.

${ }^{278}$ CONADEP. Nunca más: informe de la Comision Nacional sobre la Desaparición de Personas. 8. ed. 5. reimp. Buenos Aires: Eudeba, 2013. p. 59.
} 
O cérebro do Terrorismo de Estado Argentino (TEA) era o Batalhão de Inteligência 601, o B. 601, cuja sede ficava na esquina das ruas Callao e Viamonte, em Buenos Aires. O B. 601 articulava os serviços de espionagem, centralizando as informações. ${ }^{279}$

O Batalhão de Inteligência 601 tinha sob sua responsabilidade a articulação dos serviços de espionagem, declaradamente um serviço de informações e também a execução de operações, não apenas no território argentino mas com agentes atuando em outros países. Vale ressaltar que operações, nesse contexto, foram as práticas de sequestro, tortura e desaparecimento. Contava em seus quadros com os considerados especialistas em interrogatórios e repressão - era o B601 que designava em qual centro de detenção clandestina um "interrogador" iria atuar e também quanto tempo permaneceria. Em geral os interrogadores atuavam em diversos chupaderos.

Em 2010 o Archivo Nacional de la Memoria entregou para a justiça argentina uma lista com nomes de 915 civis e 108 suboficiais que atuaram no B601. Porém, estimava-se que o número de agentes passasse de 6 mil, ainda que não todos atuassem nas ações repressivas. ${ }^{280}$ Em 2013 foi entregue para a justiça a lista considerada oficial, pois a assinatura é de um chefe de inteligência do Exército, César Milani ${ }^{281}$. Nesta lista constam 4.297 nomes. Destes 345 militares, 2353 que atuaram em diferentes lugares do país, e 1599 civis que atuaram na sede do Batalhão 601 na capital da Argentina entre os anos 1976 e $1983 .{ }^{282}$ Após a divulgação deste documento foi possível compreender o tamanho da estrutura repressiva que o B601 comandava.

O ápice da implantação de centros de detenção clandestinos, sob comando do B 601, ocorreu nos dois primeiros anos após o golpe, de 1976 à 1978, período no qual foram alugadas ou tomadas por empréstimo diversas fazendas ou casas, bem como utilizadas estruturas militares para esse fim. ${ }^{283}$ Sobre os objetivos dos “chupaderos", Zarankin afirma:

\footnotetext{
${ }^{279}$ MARIANO, S. Nilson. Montoneros no Brasil - Terrorismo de Estado no seqüestro-desaparecimento de seis guerrilheiros argentinos. Porto Alegre: PUCRS, 2006. Dissertação, Mestrado em História - PUCRS. Porto Alegre, p. 49.

${ }^{280} \mathrm{http}: / /$ tiempoargentino.com/nota/72436/aportan-un-nuevo-listado-del-batallon-601

281 Este documento contém seis páginas e está disponível em: http://www.desaparecidos.org/arg/tort/listas/601a.pdf

${ }^{282} \mathrm{https}$ ://leyendadeltiempo.wordpress.com/la-lista-del-batallon-601/

${ }^{283}$ Cf. GUAZZELli, Cesar Augusto Barcellos. História Contemporânea da América Latina: 1960-1990. 2. ed. Porto Alegre: Editora da UFRGS, 2004. Cf. PASCUAL, Alejandra L. Terrorismo de Estado - A Argentina de 1976 a 1983. Florianópolis: UFSC, 1997. Tese, Doutorado em Direito - UFSC. Florianópolis, 1997. Cf. ROMERO, A. Luis. História Contemporânea da Argentina. Rio de Janeiro: Jorge Zahar Ed. 2006. Cf. STEINKE, Sabrina. Apontamentos sobre a transição democrática argentina. Anais do XXVI Simpósio Nacional de História. ANPUH. São Paulo, julho de 2011. p.8.
} 
Os Centros Clandestinos de Detención (CCD'S), utilizados por la dictadura militar en Argentina entre 1976 y 1983, para destruir la movilidad, aplicación de tormentos, falta de alimentos, condiciones climáticas extremas (frio o calor), prohibición de comunicación con otras personas, sustitución del nombre por um numero, entre otras, son dispositivos que tienen, principalmente, como foco de acción directa cuerpo y mente del detenido. ${ }^{284}$

A famigerada "guerra contra a subversão" mantinha esses centros como meio e fim dos propósitos pretendidos pelos articuladores do golpe. A relevância das prisões clandestinas é imprescindível para compreender esse processo histórico. Esses locais representavam, na prática, o que a teoria que deu substrato ao golpe propagava. O Batalhão 601 articulou a consumação efetiva da Doutrina de Segurança Nacional. Em Paso de los Libres, o B601 estave presente por meio do Destacamento 123 e de seus agentes que atuaram na repressão nesta região.

A boataria acerca da existência de uma prisão clandestina em Paso de los Libres foi assunto recorrente na cidade e região, tema que era transmitido no "boca em boca" pelos funcionários da aduana. Foi na aduana que a autora desta Tese ouviu pela primeira vez as histórias da repressão ocorridas nessa fronteira. Os Gendarmes comentam com certa naturalidade supostas ocorrências repressivas no local durante os anos de ditadura, como se estivessem contando um "causo". Todas as vezes que a autora desta Tese indagou-lhes se dariam uma declaração formal sobre o tema responderam: "es chiste, broma", e em seguida mudavam de assunto. Para além da aduana, era muito comentado na cidade a existência de um relato, que teria sido produzido por um ex-agente civil do Destacamento 123, em que denunciava um local que serviu de prisão clandestina e como funcionou a logística repressiva em Paso de los Libres.

Em 2004, o argentino Carlos Fidel Waern, que teria escrito tal relato, foi convidado para participar de um programa televisivo para, a princípio, comentar a situação política local. No intervalo comercial desse programa, o entrevistador fez perguntas acerca do período em que Waern trabalhou para o D123. Entre os questionamentos, a existência desse relato. $\mathrm{O}$ entrevistado respondeu as perguntas e afirmou ter escrito sobre a prisão clandestina e a atuação do D123. As declarações feitas durante o intervalo do programa de televisão foram veiculadas pelo jornalista em seu programa, e a história da prisão clandestina se tornou pública e midiática.

${ }^{284}$ ZARANKIN, Andrés; NIRO, Claudio. La materialización del sadismo. Arqueologia de la arquitectura de los Centros Clandestinos de Detención de la dictadura militar argentina (1976-1983). Pg. 164. In.: ZARANKIN, Andrés; FUNARI, Pedro Paulo (Comp.). Arqueologia de la represión y la resistência en America Latina: 1960-1980. Córdoba: Encuentro Grupo Editor, 2006. 
Uma reportagem do jornal "SEPA" 285 delineou ocorrências repressivas em Paso de los Libres. A prisão denunciada por Waern, e presente na reportagem do periódico, é uma fazenda de criação de gado, a chamada La Polaca. Entre o segundo semestre de 1976 e novembro de 1983, esta estância esteve cedida gratuitamente para o Destacamento 123 do Exército argentino.

Após a exposição na mídia das atividades repressivas ocorridas na fazenda, deu-se início no Juzgado Federal Argentino de Paso de los Libres um processo para averiguar as atividades da estância La Polaca enquanto esteve cedida ao Destacamento $123 .{ }^{286} \mathrm{Na}$ Argentina, o Juiz é também reponsável pela investigação, e o processo judicial começa com as investigações - não há um inquérito prévio, como no Brasil.

O Juzgado Federal de Paso de los Libres começou a investigação por causa do relato feito por Carlos Fidel Waern. Conforme o processo, foi a declaração de um ex-agente civil que integrou os grupos de tarefas durante o período ditatorial mais recente, que colocou em pauta a existência deste centro de detenção clandestino em Paso de los Libres. Até então, Carlos era desacreditado na cidade por ser alcoólatra, porém o detalhamento dado em sua fala na televisão, bem como o conteúdo do manuscrito, agregados com as desconfianças acerca de uma repressão mais intensa na região, fizeram com que a investigação fosse aberta. ${ }^{287}$

A princípio, Carlos negou ser o autor, porém o manuscrito foi submetido à perícia, confirmando sua autoria. Importantes revelações foram feitas no relato, destacando a estrutura militar na Argentina e sua ampliação após a instauração do Processo de Reorganização Nacional. São descritos os operativos e a hierarquia militar repressiva. O relato, em diversas passagens, demonstra as relações das redes sociais em que ele estava inserido. Waern expõe a existência de um processo complexo e extremamente organizado.

285 "La Polaca, un campo de concentración y exterminio en Paso de los Libres". Jornal SEPA, p. 3-5, jul. 2004.

${ }^{286}$ Esse processo foi objeto de análise da dissertação de mestrado da autora desta Tese, a causa investigava se as informações veiculadas na mídia acerca da estância La Polaca eram verídicas. Na dissertação examinou-se as estratégias de defesa utilizadas no decorrer do processo, a dissertação tratou da história desse processo e da história dos crimes investigados nele. Detalhadas essas reportagens e confrontadas as ocorrências denunciadas por Waern na dissertação, bem como todos os pormenores sobre a fazenda La Polaca. Para a construção do processo histórico da pesquisa aqui apresentada, fez-se necessário retomar discussões e ideias da dissertação de mestrado da autora, com intuito de adensar as questões analisadas nesta Tese. Cf. STEINKE, Sabrina. Agentes da Ditadura Argentina nos trilhos da Justiça: embates diante de um processo crime de lesa humanidade. Porto Alegre: PUCRS, 2010. Dissertação, Mestrado em História - PUCRS. Porto Alegre. 2010.

287 ARGENTINA. Primeira Instancia de Paso de los Libres/Corrientes. Ministério Público Federal. Waern, Carlos Fidel y otros s/ supuesta comisión delitos de lesa humanidad. Expediente no: 1.78.239/04. 28-0804. Fls. 598. 
A concepção inicial do relato tem caráter de denúncia. $\mathrm{O}$ autor inicia a narrativa comentando sobre o Processo de Reorganização Nacional e vai construindo paulatinamente as etapas dos acontecimentos que ele presenciou. Aponta nomes de diversas pessoas envolvidas e as tarefas executadas por esses, até que encerra seu relato demonstrando como uma fazenda de criação de gado foi utilizada como centro de detenção clandestino.

Sobre a utilização da fazenda enquanto prisão, Waern dá detalhes do processo, desde a captura de um suspeito até o funcionamento da prisão. Consta que a princípio as pessoas eram detidas e "interrogadas" na própria aduana, em uma sala chamada "Local 13" - essa sala tem os vidros pintados de branco e atualmente encontra-se fechada. Conforme o relato, com o passar do tempo, a repressão ficou mais intensa em Paso de los Libres, devido a chegada dos "marcadores", e a necessidade de arrumar outro local para interrogatórios foi latente. Foi então que a fazenda La Polaca foi emprestada ao D123.

Com a intenção de que os sequestradores não fossem identificados, a vítima era levada até a fazenda com os olhos vendados até uma parte do caminho, onde outro carro estava aguardando, veículos da inteligência que os levava ao destino: a prisão clandestina. A fazenda era constituída por uma casa de quatro quartos e um porão, ao lado havia outra edificação que era utilizada como cozinha e local de descanso dos agentes. A casa permanecia discreta, por estar rodeada de muitas árvores, uma parte de eucaliptos, e um canavial. Carlos também escreveu que do portão de entrada até a casa o caminho percorrido era de cerca de 500 metros. Nenhum movimento dos agentes era realizado sem comunicação prévia, bem como não era possível que estranhos tivessem acesso, por estar sempre com os portões trancados e estava localizada no final da estrada. ${ }^{288}$

A justiça ao confrontar as informações do relato com os documentos da fazenda, como plantas, desenhos elaborados com base nas informações topográficas contidas na escritura da fazenda, não teve dúvidas de que o local apontado por Carlos era mesmo a fazenda La Polaca.

Sobre prisioneiros, Waern sustenta que os interrogatórios eram executados no período da noite, com raras exceções ocorrendo durante o dia. Também detalha as torturas que eram praticadas no local, como "teléfono de campaña" e "picana eléctrica". "Se llegó a tener hasta seis prisioneros encapuchados, encadenados a una cama (sin colchón y con los flejes en contacto con es cuerpo desnudo). No les daba de comer, apenas agua y acompañarlo al

${ }^{288}$ ARGENTINA. Primeira Instancia de Paso de los Libres/Corrientes. Ministério Público Federal. Waern, Carlos Fidel y otros s/ supuesta comisión delitos de lesa humanidad. Expediente $\mathbf{n}^{\mathbf{0}}$ : 1.78.239/04. 28-0804. Fls. 520-521. 
baño". ${ }^{289}$ Carlos afirma que por volta de cem prisioneiros passaram pela La Polaca, e que era uma prisão de "trânsito", a maioria dos detidos passavam poucas horas no local e depois eram transferidos para outras prisões. Segundo Carlos, seria um lugar de "selección”.

Dois grupos de centro de detenção clandestino foram categorizados pela CONADEP, com base nos testemunhos de pessoas que passaram por esses locais:

Lugar de Reunión de Detenidos (LRD): Centros donde los detenidos eran mantenidos en general por periodos considerables de tiempo hasta que se decidia su destino definitivo.

Lugar transitorio (LT): El tiempo de detención era - salvo excepción - corto. A estos lugares el detenido llegaba inmediatamente después del secuestro o, si así se determinaba, en el periodo previo a su liberación o a su puesta a disposición del Poder Ejecutivo Nacional. ${ }^{290}$

Carlos aponta em suas experiências na La Polaca que poucos detidos passaram mais de dois dias no local, e também relata as torturas praticadas ali. O relato aponta que já havia um local para um primeiro "interrogatório" na própria aduana, o Local 13, uma sala entre os demais escritórios do centro aduaneiro. Plausível o relato de Waern, chamava a atenção uma sala com os vidros pintados e movimentação suspeita, tão evidente ao público em geral. Dessa forma a utilização da La Polaca como prisão foi providencial. Tirava o foco da aduana e estava localizada em local não distante deste terminal, além de estar situada muito próxima da margem do Rio Uruguai, o que fazia com que o trânsito em frente fosse praticamente inexistente. Durante o andamento do processo acerca da La Polaca um rapaz deu seu testemunho dizendo ter sido preso e torturado naquela estância.

Em agosto de 2005, Luís Rolón procurou a Fiscalía Federal de Goya. Em 1978, Luís prestava serviços em uma unidade militar de Monte Caseros, na província de Corrientes. Durante um treinamento com intuito de combater guerrilha foi solicitado que os soldados desenhassem um local que eles conheciam para que a capacidade de reconhecimento de cada um fosse testada. Luís resolveu desenhar o Regimiento de Monte Caseros, quando um suboficial viu seu desenho chamou-o de subversivo e em seguida foi levado para um carro modelo falcón com pessoas que ele não conhecia e que pareciam civis, já que nunca os tinha visto no destacamento militar. Imediatamente foi encapuzado, em seguida o carro estacionou e ele começou a ser torturado, retornaram à viagem até que chegaram no que ele chama de

${ }^{289}$ ARGENTINA. Primeira Instancia de Paso de los Libres/Corrientes. Ministério Público Federal. Waern, Carlos Fidel y otros s/ supuesta comisión delitos de lesa humanidad. Expediente no: 1.78.239/04. 28-0804. Fls. 521.

${ }^{290}$ CONADEP. Nunca más: informe de la Comision Nacional sobre la Desaparición de Personas. 8. ed. 5. reimp. Buenos Aires: Eudeba, 2013. p. 83. 
"destino", onde foi torturado intensamente, foi retirado desse local por uns dias e depois retornou. Rolón pediu que seus antecedentes fossem investigados, pois disse nunca ter feito parte de qualquer reunião política. De fato, foi comprovada a inocência de Rolón: ${ }^{291}$

\begin{abstract}
Al comprobar mi inocencia me comunican que me van a volver al Regimiento entonces me suben al vehículo sin capucha diciéndome que no mire para tras pero al doblar en la tranquera pude ver y reconocer el lugar de mi detención, a donde me torturaban y era "La Polaca" en Paso de los Libres y puedo asegurar que en ese lugar había otras personas detenidas y torturadas, ahí me llevan al Regimiento de Monte Caseros donde estuve un año y cinco meses detenido y luego me llevan a un Consejo Militar en Córdoba donde obtengo mi libertad. ${ }^{292}$
\end{abstract}

Rolón esteve em Paso de los Libres e fez reconhecimento da La Polaca. Antes da visita ao local, ele descreveu a estrutura interna da casa; ainda no depoimento ele reconheceu por fotos a entrada da estância. Várias diligências foram feitas até a estância La Polaca durante as investigações. O pesquisador Nilson Mariano esteve lá e inclusive tirou medidas do porão $^{293}$. Jair Krischke também esteve na estância junto com a esposa de Lorenzo Ismael Viñas. Rolón é a única testemunha que denunciou torturas na La Polaca até o momento. A prisão de Luis Rolón foi equivocada, assim como ocorreu com outras pessoas - os casos de erro são estimados em 25\%, considerando os 30.000 detidos-desaparecidos o número de equívocos seria em torno de 7.500 pessoas $^{294}$.

Carlos Fidel Waern, sozinho, não projetava a estruturação de um centro de detenção clandestino, nem esquematizou as prisões e torturas ocorridas no local que foi seu endereço profissional por mais de três anos. Também, sós não estavam os homens que ele acusa ${ }^{295}$. Uma prisão clandestina não se implementa por si só, ou com um só ator. Calveiro aponta que para compreender o fenômeno das prisões clandestinas é preciso que se faça referência a alguns atores políticos que coexistiam nesses locais, seja "administrándolos o padeciéndolos". 296

291 ARGENTINA. Primeira Instancia de Paso de los Libres/Corrientes. Ministério Público Federal. Waern, Carlos Fidel y otros s/ supuesta comisión delitos de lesa humanidad. Expediente n ${ }^{\mathbf{0}}: \mathbf{1 . 7 8 . 2 3 9 / 0 4}$. 28-0804. Fls. 5325.

292 Ibidem, fls. 1290.

${ }^{293}$ MARIANO, S. Nilson. Montoneros no Brasil - Terrorismo de Estado no seqüestro-desaparecimento de seis guerrilheiros argentinos. Porto Alegre: PUCRS, 2006. Dissertação, Mestrado em História - PUCRS. Porto Alegre, p. 94.

${ }^{294}$ DUHALDE, Eduardo Luis. El Estado Terrorista argentino. 1. ed. Ciudad Autónoma de Buenos Aires: Colihue, 2013. p. 338.

${ }^{295}$ STEINKE, Sabrina. Agentes da Ditadura Argentina nos trilhos da Justiça: embates diante de um processo crime de lesa humanidade. Porto Alegre: PUCRS, 2010. Dissertação, Mestrado em História - PUCRS. Porto Alegre. 2010. p. 60-65.

296 CALVEIRO, Pilar. Poder y desaparición: los campos de concentración en Argentina. 1. ed. 6. reimp. Buenos Aires: Colihue, 2008. p. 7. 
Esse foi o funcionamento desse centro clandestino de detenção na fronteira. No final dos anos 1970 os Montoneros eram os mais buscados pela repressão, por ser a organização que ainda estava ativa e tinha ainda uma certa relevância no cenário político Argentino e do Cone Sul. Havia, sim, outros grupos políticos ou indivíduos, sem vínculos com organizações políticas, que também foram alvo da repressão. São, porém, os montoneros objeto desta análise por sua relevância e pela existência de fontes sobre eles na fronteira.

\subsection{Motoneros}

A existência de uma prisão clandestina em Paso de los Libres de 1976 até 1983 aponta para a configuração ampla da repressão como um todo, e pontual no que tange um grupo específico. Quem era o principal alvo dessa "guerra contra a subversão"? Ademais de entender que, em época de Doutrina de Segurança Nacional qualquer um poderia ser considerado "inimigo", "suspeito", como Luís Rolón, por exemplo, é sabido que alguns grupos eram o foco principal.

Nos anos 1960 impulsionados pela experiência cubana e a ação de Che Guevara na Bolívia, surgiram na Argentina as primeiras organizações guerrilheiras, em um primeiro momento sem muita reverberação em seus campos de atuação, que era o político social. Advindas principalmente de organizações de trabalhadores, sindicalizadas ou não, foram se transmutando a partir das experiências vivenciadas e da conjuntura política. Entre os anos de 1959 e 1968, através da luta armada rural três grupos tentavam se implantar: Los Uturuncos, Ejército Guerrillero del Pueblo (EGP) e Fuerzas Armadas Peronistas (FAP). No começo dos anos 1970 havia sete grupos estruturados atuando na Argentina: Fuerzas Armadas Revolucionarias (FAR), Fuerzas Argentinas de Liberación (FAL), Ejército Revolucionario del Pueblo (ERP), Guerrilla para el Ejército de Liberación (GEL), Descamisados e Montoneros,

além das FAP, que seguiam estruturadas. ${ }^{297}$ Mas essas foram experiências particulares de luta armada e distintas do que foi vivenciado pelos grupos de esquerda dos anos 1970. As organizações de viés político peronista confluíram nos Montoneros da metade dos anos 1960 em diante, permanecendo com maior expressão o ERP e os Montoneros.

${ }^{297}$ GASPARINI, Juan. Montoneros: final de cuentas. 2. ed. 1. reimp. La Plata: De la Campana, 2008. p.23. 
De 1970 até 1973 os atos de violência e grande repercussão das ações armadas desses dois grupos se evidenciaram, principalmente os Montoneros. O sequestro e assassinato de Aramburu foi o ato mais emblemático dessa faceta do "braço armado do peronismo"298 e da luta armada em si. Sarlo aponta que esse ato de "justiça/vingança” é o que definiu quem eram os montoneros e no que eles se diferenciavam de outros grupos guerrilheiros, Vezzetti e Gasparini $^{299}$ apontam esse como um ato fundador da luta armada pelos Montoneros. Aramburu era a presentificação de tudo que os Montoneros lutavam contra, de uma ideologia que combatiam ${ }^{300}$. O sequestro e "julgamento" de um ex-presidente, que era visto pelos Montoneros como a representação do exílio de Perón e da repressão aos peronistas, foi reverberado como um ato de justiça e vingança, que demonstrou que os Montoneros estavam dispostos ser a via que abriria caminho para uma Argentina mais inclusiva, mesmo que isso custasse sacrifício pessoal de seus militantes.

Dentre os grupos guerrilheiros, os Montoneros foram os que alcançaram de forma mais exitosa se inserir na sociedade, e conseguiram que outros grupos de oposição política se agregassem aos seus quadros - exceto o ERP, que se manteve independente. De 1971 em diante os Montoneros foram consolidando sua atuação no campo da militância social e ampliando sua abrangência, tanto que se tornaram um dos grupos mais fortes da Argentina, e certamente o mais emblemático. Buscaram mobilização em distintos setores, tanto em subúrbios como em universidades, e em escala menos avançada nos sindicatos, por meio da Juventude Peronista. Ao mesmo tempo que os Montoneros cresciam, o presidente Onganía vinha perdendo campo político de forma substancial: logo após o Aramburazo, foi deposto e a Junta dos Comandantes nomeou o General Roberto Levingston que governou até março de 1971. O cenário político se tornou muito conflituoso desde então:

${ }^{298}$ Uma ofensiva montonera no final de maio de 1970 sequestrou Pedro Eugenio Aramburu que foi um dirigente odiado pelos peronistas, pois havia derrubado Perón em 1955. A operação contou com dois guerrilheiros disfarçados de oficiais militares que invadiram seu apartamento, do lado de fora esperavam três carros. Foi levado e mantido em cárcere privado em uma casa próxima de Buenos Aires, foi interrogado e condenado pelo "tribunal revolucionário" com a sentença de morte por fuzilamento. Seus crimes: morte de 27 civis e oito militares que haviam sido inocentados no Conselho de Guerra, mas Aramburu não respeitou essa decisão; repressão ao movimento peronista; profanação do túmulo e desaparecimento dos restos de Evita; campanha pública contra os dirigentes montoneros; anulação de conquistas sociais implementadas por Perón e política liberal. No comando dessa ação estavam alguns dos fundadores dos Montoneros, Mario Firmenich, Fernando Luis Abal Medina e Esther Norma Arrostito. Cf. SARLO, Beatriz. La pasión y la excepción. 1. ed. Buenos Aires: Siglo Veinteuno Editores. 2003. p. 139-153.

${ }^{299}$ Cf. GASPARINI, Juan. Montoneros: final de cuentas. 2. ed. 1. reimp. La Plata: De la Campana, 2008. Cf. VEZZETTI, Hugo. Sobre la violencia revolucionaria: memorias y olvidos. 1. ed. Buenos Aires: Siglo Veintiuno Editores, 2009b.

${ }^{300}$ SARLO, Beatriz. Tempo presente: notas sobre a mudança de uma cultura. Rio de Janeiro: José Olympio, 2005. p. 135. 
As discrepâncias em torno de como enfrentar as organizações armadas e os protestos sociais eram crescentes e anunciavam futuros dilemas. Ao mesmo tempo em que foram criados um fórum anti-subversivo e tribunais especiais para julgar os guerrilheiros, alguns setores do Estado e as Forças Armadas iniciaram uma repressão ilegal: sequestro, tortura, desaparecimento e assassinatos de militantes. ${ }^{301}$

Nos anos que se seguiram ocorreram diversas ações armadas, principalmente dos Montoneros e do ERP. Em realidade, o embate entre guerrilha armada e Forças Armadas se intensificou, as organizações armadas se incutiram nos movimentos populares e a repressão respondia a altura. A luta armada usava como justificativa a violência praticada pelo Estado para corroborar suas ações, e eram apoiados por diversos setores que acreditavam ser esse o caminho para o fim dos sucessivos golpes e para a implementação de uma política com viés abrangente e social.

Essa resposta positiva, de parcelas da sociedade, inicialmente deu margem para que a confiança na efetividade da luta armada em abordar conflitos fosse propulsora de diversas ações armadas, ao mesmo tempo em que a repressão aumentava consideravelmente. Nesse sentido, os Montoneros foram se distanciando de uma parte considerável de seus simpatizantes. Ao mesmo tempo em que ampliavam a militarização de suas ações, perdiam apoio popular e incitavam uma repressão cada vez mais intensa das Forças Armadas,

El proceso de militarización de las organizaciones y la consecuente desvinculación de la lucha de masas tuvieron dos vertientes principales: por una parte el intento de construir, como actividad prioritaria, un ejército popular que se pretendia con las mismas características de un ejército regular, por otra la represión que, sobre todo en el caso de Montoneros, la fue obligando a abandonar el amplio trabajo de base desarrollado entre 1972 y $1974 .^{302}$

Porém, o que foi considerado por uma parte dos Montoneros como linha a ser seguida - a da violência - também foi o que contribuiu para seu esfacelamento. Aos poucos foram sucumbindo; inclusive, à época do golpe de 1976, já não estavam tão articulados e estruturados como nos tempos de apogeu:

Montoneros pasaría de una época jalonada por la actividad politica de masas entre 1973 y 1974, donde impulsó agrupaciones como la Juventud Peronista, la Juventud Trabajadora Peronista, la Unión de Estudiantes Secundarios, la Juventud Universitaria Peronista y la Agrupación Evita, a un momento de repliegue, reorganización y creciente aislamiento entre 1975 y $1976 .{ }^{303}$

\footnotetext{
${ }^{301}$ ROMERO, A. Luis. História Contemporânea da Argentina. Rio de Janeiro: Jorge Zahar Ed. 2006. p. 178.

${ }^{302}$ CALVEIRO, Pilar. Poder y desaparición: los campos de concentración en Argentina. 1. ed. 6. reimp. Buenos Aires: Colihue, 2008. p. 16-17.

${ }^{303}$ CAMPOS, Esteban. Memoria, ensayos y polémicas. El balance de la experiencia montonera en los años 1980.

Topoi, v. 14, n. 26, p. 11, jan./jul. 2013.
} 
A volta para a clandestinidade e a militarização do grupo foram fatores que contribuíram para seu paulatino processo de desmembramento. Os montoneros permaneceram um grupo muito forte, mas já não tinham o apoio da sociedade com que contavam alhures principalmente após o golpe, já que o militante Montonero foi taxado como combatente, mesmo que não tivesse participado de treinamento ou ações armadas. Inclusive, a "guerra contra a subversão" foi um dos pontos mais difundidos pela Junta Militar como uma das justificativas para o golpe de 1976.

Vezzetti aponta que a experiência montonera tem sido objeto de diversas análises nos últimos anos, com um olhar para além do viés "ação e reação" e da luta armada em si e no “matar o morir por la revolución". ${ }^{304}$ Quando se tenta encontrar as ascendências da violência na Argentina recente, em geral, se alcança uma narrativa ligada a tradição peronista que sustenta a versão de que as organizações armadas foram uma reação às políticas de Estado. Nesse ponto, tanto Vezzetti quanto Calveiro ${ }^{305}$ apontam três momentos que impulsionaram essa reação e, principalmente, a utilização da violência no campo político: "el bombardeo a Plaza de Mayo y el derrocamiento de Perón en 1955, y cristalizó en el golpe reaccionario de 1966. En ese relato, un hilo continuo hilvana el desarrollo de las luchas, desde la Resistencia peronista hasta la guerrilla montonera ${ }^{\text {,306. }}$.

Porém essa visão não abrange a complexidade desse movimento, bem como não explica, por si, como se deu essa militarização de grupos que a princípio eram de cunho político. Ou seja, a transformação de uma luta no campo político para uma luta políticomilitar. Ocorreu um distanciamento de ações de cunho político para confrontos armados. Conforme Vezzetti, é para além de ação e reação que se entende essa violência guerrilheira. É também assim que podemos perceber de modo mais amplo a atuação desses militantes, em particular e como um grupo.

Nesse ponto, Vezzetti aponta uma perspectiva inovadora para essa análise, uma linha de pensamento que abarca essa questão de modo político/social com enfoque abrangente, saindo do tão difundido "ação/reação", que sim, ajuda explicar as circunstâncias que fizeram de ações armadas algo "aceitável” socialmente - pelo menos por um tempo. Porém, entender os Montoneros (e os demais grupos armados) e a experiência armada de indivíduos se torna lugar comum se olharmos apenas para a questão da "ação/reação", como um processo uno

\footnotetext{
${ }^{304}$ VEZZETTI, Hugo. Sobre la violencia revolucionaria: memorias y olvidos. 1. ed. Buenos Aires: Siglo Veintiuno Editores, 2009b. p. 61.

${ }^{305}$ Cf. CALVEIRO, Pilar. Política y/o violencia: una aproximación a la guerrilla de los años setenta. 1. ed. Buenos Aires: Siglo Veintiuno Editores, 2013. Cf. VEZZETTI, op. cit.

${ }^{306}$ VEZZETTI, op. cit., p.61.
} 
tanto do grupo, como dos indivíduos envolvidos. Seguindo uma opção com enfoque apenas em violência e ação e reação, ingenuamente podemos nos encaminhar para a análise maniqueísta de um processo, que como todos os processos históricos tem suas complexidades. A perspectiva de análise da Tese é no campo político e social, para além de narrativas que apontam uma relação de bem versus mal.

O distanciamento popular dos Montoneros foi crucial para sua derrocada como grande grupo armado. A militarização ante a politização do movimento fez com que as rupturas ocorressem de forma significativa. Os quadros já não dialogavam como outrora, bem como a população já não apoiava mais as táticas guerrilheiras. Obviamente que, ainda, não está se tratando da questão do aniquilamento dos montoneros. Quando o termo derrocada é utilizado, é no sentido político, enquanto opção saudada e amparada por diversos setores. Fato dado que a repressão das Forças Armadas foi o que causou o fim de grupos armados, no sentido estrito - foi a repressão que acabou com esses grupos quando matou a maioria dos militantes.

Outro fator preponderante para o começo da derrocada dos Montoneros e que impulsionou a guerra contra a luta armada, foi o estremecimento das relações com Perón. Isso vinha ocorrendo de forma crescente, desde seu retorno do exílio na Espanha, e terminou em rompimento entre ambos:

La ruptura pública entre Perón y los Montoneros se produjo el $1^{\circ}$ de mayo [1974],
apenas dos meses antes de la muerte del general, que ocurrió el $1^{\circ}$ de julio de ese
mismo año. Si en vida de Perón había sido imposible poner bajo control a los
sindicatos, al empresariado y a la guerrilla, a su muerte los enfrentamientos
sociales y políticos se agudizaron hasta niveles extraordinarios. La pugna se desató
sin intermediación posible.

De 1974 em diante, a repressão aos grupos guerrilheiros começou a se fortalecer e conquistar apoio popular. A violência cresceu vertiginosamente, em embates de diversos níveis: entre os peronistas de direita e esquerda, os grupos armados aumentaram a guerrilha, bem como entre os paramilitares e a repressão. As ações de sequestro, tortura e morte de militantes se espalhavam por todo o país. "En agosto de 1974 [...] el Ejército asesinó a dieciséis guerrilleros del ERP que intentaban copar un regimiento. [...] En septiembre, Montoneros pasó a la clandestinidad y recrudeció su accionar armado". ${ }^{308}$

\footnotetext{
${ }^{307}$ CALVEIRO, Pilar. Política y/o violencia: una aproximación a la guerrilla de los años setenta. 1. ed. Buenos Aires: Siglo Veintiuno Editores, 2013. p. 47.

${ }^{308}$ Ibidem, p. 48.
} 
A repressão não aconteceu apenas após o golpe em 1976; a desestruturação dos grupos armados já era objetivo das Forças Armadas e já vinha sendo executada de modo secreto. Uma das bandeiras do Proceso de Reorganización Nacional era acabar com a subversão. O golpe de 1976 é emblemático por diversos fatores, mas principalmente porque pela primeira vez as três forças militares da Argentina foram unânimes e atuaram juntas de modo sistemático e organizado. As Forças Armadas estavam agindo de forma extremamente política, diferente das outras ocasiões, já que desde 1930 envergavam um cunho militarista aos golpes.

Em 1976 estavam atuando ainda na Argentina o ERP e os Montoneros. Após o golpe, apesar do forte controle de segurança implantado contra os "subversivos", os Montoneros intensificaram ao máximo que puderam suas ações armadas. Entre março e maio de 1976 suas campanhas militares realizaram, somente em Buenos Aires, segundo dados do grupo, a morte de 87 pessoas e recuperação de $101 \operatorname{armas}^{309}$. As ações se intensificaram em 1976 e 1977, porém ao mesmo tempo que se realizavam uma média de pelo menos uma operação por dia, o número de militantes que morriam e/ou desapareciam era muito mais elevado. Em dois anos a repressão das Forças Armadas eliminou em torno de 4.500 militantes montoneros. O ERP, quatro meses após o golpe, estava praticamente dizimado - Roberto Santucho, o dirigente do ERP, “caiu” em julho de 1976, quando a maioria dos militantes também já havia "desaparecido" nos centros de detenção clandestinos instalados pelas Forças Armadas.

Os montoneros resistiram um pouco mais, até por ter número maior de militantes. Em 1979, foi lançada a contraofensiva montonera. Apesar de estar em amplo descenso no campo político e militar, esse último intento focava, principalmente, os montoneros que estavam no exterior, planejavam ações de "fora para dentro", ao articularem-se desde o exterior para depois retomar a luta na Argentina, bem como angariar novos militantes aos seus quadros. A Contraofensiva Montonera posta em marcha em 1979 foi esperançada pela conjuntura política, visto que o regime estava passando por uma crise significativa, “[...] a liderança montonera ponderou que a interferência pontual da vanguarda guerrilheira, mediante ações político-militares aplicadas com precisão cirúrgica, serviria para agudizar as contradições internas do regime". 310

\footnotetext{
${ }^{309}$ Montoneros: Resumen de la campaña. Revista Evita Montonera, a. 2, n. 13, p. 21, abr./maio 1976. Disponível em: http://www.ruinasdigitales.com/revistas/Evita\%20Montonera\%2013.pdf

${ }^{310}$ FERNANDÉZ, Jorge C. Resistir es vencer: o Brasil e a Contraofensiva Montonera, 1978-1980. In: PADRÓS, Enrique S (Org.) Dossiê Ditaduras de Segurança Nacional no Cone Sul. Revista do Programa de PósGraduação em História, Porto Alegre, v. 19, n. 35, p. 212, jul. 2012.
} 
As publicações montoneras desde 1978 apontavam para essa contraofensiva, estrategicamente focada em dois pontos: político e militar. A revista "Estrella Federal", do Ejército Montonero, em setembro de 1978 tinha na capa "Preparar la contraofensiva", um editorial assinado por Mario Firmenich intitulado "Los desastres en que la dictadura ha sumergido al país ya inundan los despachos militares”, e apontava a crise econômica que a Argentina estava enfrentando sinalizava para um bom momento no campo político para aumentar a resistência. Os sindicatos estavam aos poucos se revigorando e articulando novamente. Firmenich, nesse editorial, mostrava os caminhos no campo político a serem seguidos pelos montoneros, "Debemos mantener la resistencia para hacer fracasar la nueva estrategia gorila, que pretende consolidar-se en la situación actual, y debemos preparar la contraofensiva popular para forzar la retirada de los militares" ${ }^{\text {311 }}$. Firmenich focava seu discurso no campo político.

Já o chefe do Ejército Montonero Horácio Mendizabal, na mesma revista, assinou texto intitulado "El objetivo del Ejército Montonero es: reorganizarse u alistarse para contraatacar", indicando que os militantes não estavam aniquilados, apesar do significativo número de baixas, e que mantinham capacidade operativa. Nessa mesma linha, de aumentar a adesão militar ao movimento, Campliglia também aponta a necessidade de "engrossar filas" por meio de propaganda. ${ }^{312}$

Em outubro de 1978, durante a reunião do Consejo Nacional del Partido Montonero, se articulou a estratégia da contraofensiva, com base nos documentos do partido de 1976. Esta estratégia impulsionou as já evidentes contradições entre os montoneros, conforme aponta Gasparini: "Los desprendimientos resultaban inevitables porque los papeles montoneros contrastaban como el día y la noche con lo que pasaba entre el cielo y la tierra" "313. É consenso na historiografia acerca do tema que a contraofensiva foi uma ação equivocada, desde a análise da conjuntura propagada pela Conducción Nacional até a estratégia ofensiva proposta. "La represión disminuía cuantativamente al haber menos blancos en el país. Pero no en calidad: los buscaban uno a uno. La relación de fuerzas cambiaba para peor. A partir del '77, la ofensiva enemiga, lejos de agotarse saldría a perseguirlos decididamente fuera de las fronteras". 314 As condições que foram apresentadas para a contraofensiva estavam equivocadas - apesar da crise no campo político e econômico do governo ditatorial, no que

\footnotetext{
${ }^{311}$ Los desastres en que la dictadura ha sumergido al país ya inundan los despachos militares. Revista Estrella Federal, n. 5, p. 4, set. 1978.

${ }^{312}$ Preparar la contraofensiva. Revista Estrella Federal. Revista Estrella Federal, n. 5, set. 1978.

${ }^{313}$ GASPARINI, Juan. Montoneros: final de cuentas. 2. ed. 1. reimp. La Plata: De la Campana, 2008. p. 184.

${ }^{314}$ Ibidem, p. 167.
} 
concerne à repressão, essa não tinha recrudescido, do mesmo modo que os montoneros não contavam com apoio da sociedade para ações táticas e no campo político a atuação tinha sido deixada de lado em prol da militarização, o que os enfraqueceu enquanto uma via alternativa para a sociedade.

Dentre as ações dos militares para combater a contraofensiva montonera está o Operativo Murciélago, que objetivava ações fora da Argentina, sob responsabilidade do B601. Conforme Mariano:

\begin{abstract}
Organizada pelo coronel Carlos Alberto Tepedino, a operação concentrava-se em dois cruzamentos fronteiriços, os mais utilizados pelos Montos: Paso de los LibresUruguaiana (Rio Grande do Sul), e Las Cuevas, entre a província argentina de Mendoza e Los Andes (Chile) [...]Agentes morcegos do B. 601 agiam fora da Argentina, seguindo uma das estratégias da Operação Condor, a de infiltrar espiões nas embaixadas, nos consulados, nas companhias aéreas, nas empresas multinacionais. Entre dezembro de 1978 e janeiro de 1981, o coronel Jorge Ezequiel Suárez Nelson foi agregado militar em Brasília. ${ }^{315}$
\end{abstract}

O Batallón 601, durante a ditadura, funcionou como uma associação ilícita que se dedicou a cometer crimes de lesa humanidade:

El batallón 601 tenía por debajo de su estructura la llamada Central de Reunión, que tenía a cargo "Grupos de Tareas" que eran periféricos a este y la información que recolectaban se transmitía a la Central y posteriormente al Batallón, desde allí se organizaban y se implementaban operativos, comandados por la dependencia de cada zona y se sometía a las personas detenidas a interrogatorios para obtener la mayor cantidad de información. ${ }^{316}$

No processo $^{317}$ que investiga três ex-agentes do B601 - Leandro Sanchez Reisse, Ruben Osvaldo Bufano e Arturo Silzle - está comprovada a participação efetiva desta organização militar em operações no exterior: "El batallón 601 llevo a cabo operaciones clandestinas en Brasil, Peru y México. En el marco de la contraofensiva montonera y como parte del Plan Condor "318. De certa forma, a contraofensiva montonera impulsionou as atividades do B 601 no exterior, por meio do Operativo Murciélago, e para que essas ações fossem executadas, utilizou-se da logística da Operação Condor.

\footnotetext{
${ }^{315}$ MARIANO, S. Nilson. Montoneros no Brasil - Terrorismo de Estado no seqüestro-desaparecimento de seis guerrilheiros argentinos. Porto Alegre: PUCRS, 2006. Dissertação, Mestrado em História - PUCRS. Porto Alegre, p. 51.

${ }^{316}$ ARGENTINA. Poder Judicial de la Nación. Juzgado Nacional en lo Criminal y Correccional Federal $n^{\circ} 4$. "Baca Jorge y otros s/ privación ilegal de la libertad personal. 21/09/2012. p. 2.

317 Tramita no Tribunal Federal n ${ }^{\circ} 6$ da Capital Federal (Buenos Aires) processo que investiga sequestros de empresários durante a ditadura, realizados sob comando do B 601.

318 https://www.fiscales.gob.ar/lesa-humanidad/batallon-de-inteligencia-601-juicio-oral-contra-tres-represorespor-secuestros-extorsivos/
} 


\subsection{Desaparecimentos e exílios}

Dos cidadãos argentinos desaparecidos no Brasil, primeiramente foram cinco apontados pela Comissão Especial sobre Mortos e Desaparecidos Políticos ${ }^{319}$ : Norberto Armando Habegger; Horácio Domingo Campiglia; Mónica Susana Pinus de Binstock; Lorenzo Ismael Viñas e Jorge Oscar Adur. Com a publicação do relatório da $\mathrm{CNV}^{320}$, outros quatro foram agregados: Antonio Luciano Pregoni; Enrique Ernesto Ruggia; Liliana Inés Goldenberg e Eduardo Gonzalo Escabosa, totalizando nove argentinos mortos/desaparecidos no Brasil. Dos nove, seis desapareceram no ano de 1980, todos montoneros; desses seis, Liliana e Eduardo "cometeram suicídio na iminência de serem presos na fronteira Brasil-

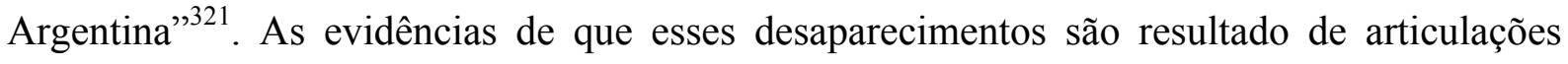
repressivas entre países latinos são enfáticas, além de terem sido assumidos enquanto conexões repressivas pelo Estado brasileiro por meio do relatório da Comissão Nacional da Verdade.

Após o golpe de 1976, um grande número de argentinos deixou o país:

[...] uma considerável parcela dos cidadãos argentinos se viu forçada a deixar seus lares, afazeres e cotidiano para partir em direção ao desterro. O fenômeno do exílio não somente era um "efeito" do terror de Estado, mas também uma ferramenta usada pelos militares para livrar-se de opositores indesejáveis. ${ }^{322}$

Geralmente a escolha dos argentinos era sair para França, Itália, Espanha - o Brasil servia como passagem em muitos casos. Muitos precisaram permanecer ou escolheram assim por diferentes motivos; é sabido, porém, que a maioria não tinha essa intenção. "Para alguns o Brasil seria apenas um lugar de passagem. Outros pensavam em ficar algum tempo até terem melhores condições econômicas e emocionais para seguir viagem ao México ou a algum país europeu". 323

319 BRASIL. Secretaria Especial de Direitos Humanos. Comissão Especial sobre Mortos e Desaparecidos Políticos. Direito à verdade e a memória: Comissão Especial sobre Mortos e Desaparecidos Políticos. Brasília: Secretaria de Direitos Humanos, 2007.

${ }^{320}$ BRASIL. Comissão Nacional da Verdade. Relatório/Comissão Nacional da Verdade. - Brasília: CNV, 2014.

${ }^{321}$ BRASIL. Comissão Nacional da Verdade. Mortos e desaparecidos políticos/Comissão Nacional da Verdade. Brasília: CNV, 2014. 1996 p. - (Relatório da Comissão Nacional da Verdade; v. 3) p. 1915.

${ }^{322}$ FERNÁNDEZ, Jorge Christian. O exílio argentino no sul do Brasil e a conexão binacional repressiva entre Argentina e Brasil. In.: PADRÓS, Enrique Serra (Org.). Cone Sul em tempos de ditadura: reflexes e debates sobre a história recente. Porto Alegre: Evangraf/UFRGS, 2013. p. 206.

323 QUADRAT, Samantha Viz. Da Argentina para o Brasil: de uma ditadura a outra. In: (Org.). Caminhos cruzados: história e memoria dos exílios latino-americanos no século XX. Rio de Janeiro: Editora FGV, 2011.p. 173. 
O intenso trânsito de "subversivos", principalmente nos anos 1970, na fronteira Uruguaiana-Paso de los Libres pode ser explicado por dois motivos: localização estratégica e o fato de a Argentina ter sido o último país, do Cone Sul, a sofrer golpe nos anos 1970, ao mesmo tempo em que o Brasil publicizava a abertura democrática. O número de militantes de diversas nacionalidades refugiados na Argentina era elevado por ser ainda um país democrático, em um Cone Sul militarizado. No sentido inverso, após o golpe argentino, muitos destes militantes procuram o Brasil como refúgio. Essas experiências são exílios - nos casos desta Tese, exílios políticos. Exílio é deslocamento; os homens se deslocam por inúmeras causas. É uma experiência tão antiga quanto a humanidade, sendo que esses deslocamentos podem ser forçados ou por motivações pessoais.

Nesta pesquisa, foram encontrados casos de militantes políticos que foram forçados deixar seus países em busca de segurança em outros. Pessoas que, ao perceber o cerco repressivo, partiram para o exílio, mesmo que não fossem considerados "subversivos", pois de algum modo estavam ligados e/ou tinham contato com militantes políticos.

Devido às circunstâncias políticas, é sabido que a grande maioria dessas pessoas ingressava de modo clandestino ou com visto de turista - eram raros os que pediam asilo em outro país. No caso do Brasil, muitos utilizaram o país como lugar de passagem, com intuito de seguir viagem, principalmente, para o continente europeu. Alguns acabaram permanecendo temporadas mais extensas, mas ainda assim sem oficializar esta situação.

O número de argentinos no Brasil foi intensificado, principalmente após o golpe de 1976. Existiu um "tripé” de exílios: Brasil - Chile - Argentina. Até o golpe de 1973 no Chile, esse país era o mais recebia brasileiros e argentinos. Para os brasileiros, a Argentina servia de “corredor" - lógica que se inverte, ao ser implantado o golpe chileno, uma vez que os lá refugiados passaram a voltar para a Argentina. Em 1976 - e até antes disso - um dos "caminhos" foi o Brasil:

[...] desde o início da escalada da violência política na Argentina, antes mesmo do golpe de 1976, a ditadura brasileira assistiu, não sem preocupação, a um movimento diferente do que até então estava acostumada: a chegada de argentinos que buscavam abrigos em outras terras. A ditadura brasileira acompanhava com atenção os passos dos países vizinhos. [...] A vinda de argentinos para o Brasil não era motivo de preocupação apenas para o governo brasileiro; a ditadura na Argentina também acompanhava os passos de seus cidadãos. Nutria a mesma preocupação: a decisão de permanecer num país vizinho apontava para um possível retorno. ${ }^{324}$

324 QUADRAT, Samantha Viz. Da Argentina para o Brasil: de uma ditadura a outra. In: (Org.). Caminhos cruzados: história e memoria dos exílios latino-americanos no século XX. Rio de Janeiro: Editora FGV, 2011. p. 170. 
Conforme aponta Quadrat ${ }^{325}$, nos casos de exílio de argentinos no Brasil podem ser identificadas duas gerações. Um primeiro momento após 1966, devido a "Revolução Argentina"; esse exílio era composto principalmente por intelectuais. A segunda geração de exilados no Brasil foi formada por uma pluralidade de cidadãos, que passaram a chegar antes mesmo do golpe de 1976 naquele país. Motivados pelas medidas repressivas autorizadas pelo governo ainda democrático e por outras ações da Triple A, pessoas de diferentes idades, níveis sociais, e formação social e política buscaram asilo no país.

As ondas de exilados brasileiros, geradas a partir de 1964, são uma das evidências mais palpáveis do terrorismo de Estado imposto no Brasil pelos governos militares. Após o golpe, muitos cidadãos brasileiros foram buscar refúgio longe de seu país, incluindo aqueles que foram expulsos. A Doutrina de Segurança Nacional era a base ideológica da ditadura, que causou o exílio de muitas personalidades públicas, artistas, intelectuais e estudantes. Exílios do medo e do terror, imposto não só no seu país mas na região que o cerca. Exílios e fugas foram formas de resistência e segurança, utilizadas pelos militantes políticos. Essas fugas tinham como causa a política governamental calcada na defesa do Estado contra os "inimigos internos".

O exílio é motivado por questões políticas; porém, nem todos os exilados foram militantes políticos. Yankelevich comenta,

\footnotetext{
Entre os exilados, uma parte estava integrada por militantes com uma clara adesão política, mas uma percentagem importante dos que decidiram e puderam exilar-se o fez por um temor lógico à repressão, apesar de não ser o que as ditaduras consideravam "subversivos": entre eles, amigos e familiares de detidos ou de "desaparecidos", [...] indivíduos que haviam realizado atividades de tipo sindical ou intelectual, [...] professores universitários, estudantes, jornalistas, gente vinculada ao mundo da cultura e das artes. ${ }^{326}$
}

Os casos estudados no próximo capítulo desta Tese são de exílios políticos, dois com clara adesão militante: Lorenzo Isamel Viñas e padre Jorge Oscar Adur atuavam no grupo Montoneros. Cristina Gloria Fiori de Vivo, ao que consta, não tinha ligação com grupos militantes, mas mesmo assim foi vítima de uma conexão repressiva.

${ }^{325}$ QUADRAT, Samantha V. Memórias do exílio argentino no Brasil. In: X Encontro Nacional de História Oral. Testemunhos: História e Política. Universidade Federal de Pernanbuco (UFPE) Centro de Filosofia e Ciências Humanas. Recife/PE. 26-30 de abril de 2010.

326 YANKELEVICH, Pablo. Estudar o exílio. In: QUADRAT, Samantha Viz (Org.). Caminhos cruzados: história e memoria dos exílios latino-americanos no século XX. Rio de Janeiro: Editora FGV, 2011. p. 16. 


\section{A POLTRONA 11}

Aclara que la declarante que antes de que viajara Lorenzo tomó nota del número de colectivo que era 7825 y el número de pasaje 93034, asiento 11 y que luego por averiguaciones se entera que el asiento $n^{\circ} 11$, la Operación Cóndor, le asignaba a las personas sospechosas que había que detenerlas, también se enteró el tener acceso al Legajo $n^{\circ} 400$ del Padre Adur, ante la CONADEP, que al sacerdote Adur también le habian asignado el asiento $n^{\circ} 11$ en la empresa General Urquiza. ${ }^{327}$

Durante os anos de terrorismo de Estado, a província de Corrientes estava sob o comando do Segundo Cuerpo del Ejército - Zona de Defensa II. O território correntino era dividido em duas subzonas, 23 e 24. Paso de los Libres estava sob a jurisdição da subzona 24 em que operava o Destacamento de Inteligência 123. Segundo levantamento da Procuración General de la Nación, até o ano de 2009 esta subzona concentrou, presumidamente, 33 vítimas de crimes contra a humanidade.

Este capítulo trata de três casos, incluindo o de Lorenzo Ismael Viñas e do padre Jorge Oscar Adur, ambos desaparecidos na mesma data, porém em horários diferentes. Ainda nesta etapa são abordados os “marcadores” e um agente da repressão, “Turco Julían”, acusado de diversos crimes contra a humanidade, e que atuou na fronteira Uruguaiana-Paso de los Libres. Aborda, por fim, os emblemáticos casos de Margarita Mengol Villas de Moroz e Cristina Gloria Fiori, detidas em Uruguaiana através de uma ação colaborativa entre policiais argentinos e brasileiros.

\subsection{Os agentes do Batalhão 601}

A estrutura repressiva na Argentina contava com um sistema chamado de “marcadores”, cujo responsável era o Batalhão 601. Os "marcadores” eram pessoas que, ao serem capturadas pelos agentes da repressão, colaboravam com seus algozes - "marcavam" supostos subversivos, além de fornecer informações sobre companheiros e locais de reuniões. Essas pessoas atuavam sob as ordens de um "agente morcego"; esse, por sua vez, agia no Operativo Murciélago, onde atuavam civis e militares torturando e assassinando pessoas. Esse operativo era responsável pelas atividades repressivas no exterior. Um "agente morcego" deveria ter muita experiência em tortura e facilidade para deslocamentos constantes. ${ }^{328}$

\footnotetext{
${ }^{327}$ ARGENTINA. Primeira Instancia de Paso de los Libres/Corrientes. Ministério Público Federal. Waern, Carlos Fidel y otros s/ supuesta comisión delitos de lesa humanidad. Expediente n ${ }^{\mathbf{0}}: \mathbf{1 . 7 8 . 2 3 9 / 0 4}$. 28-0804. Fls. 632.

${ }^{328}$ Argentina. "Riveros, Santiago Omar s/privacion ilegal de la libertad, tormentos, homicidios y otros". Juzgado Federal de San Martín. Causa no 4012.
} 
Paso de los Libres contou com a presença de pelo menos um desses agentes. Conhecido como “El Turco Julián”, era um dos mais conhecidos e experientes na repressão Argentina, e exerceu atividades em diversos centros de detenção clandestinos. Conforme Grimson, o sistema de marcadores funcionava da seguinte forma:

[...] A mediados de 1978 y probablemente hasta 1982, se instalo en la cabecera
argentina del puente internacional un control clandestino, oculto, conocido como el
"sistema de los marcadores". Los llamados "marcadores" (o también "dedos
duros") eran cuadros de organizaciones armadas que habian sido secuestrados y
torturados por el Ejército (o en otros casos por la Armada) y que habian,
supuestamente, decidido colaborar con los militares para salvar su vida. [...] el
sistema de marcadores que consistía en que los "quebrados" [marcadores] debian
reconocer en los pasos fronterizos a compañeros de su organización, delatarlos y
facilitar de ese modo su secuestro y posterior desaparición. ${ }^{329}$

Uma das "marcadoras" que atuou na fronteira Uruguaiana-Paso de los Libres foi Chela. Seu nome real é Silvia Noemi Tolchinsky, foi tenente na organização Montoneros e conhecia grande parte dos militantes desse movimento. Ela também trabalhou junto com a Condução Nacional do grupo, e era uma das mais bem informadas sobre a estrutura, ações e militantes "montos".

A prisão de "Chela" aconteceu em 9 de setembro de 1980. Ela tentava sair da Argentina para exilar-se no México, mas foi presa em Las Cuevas, próximo ao Chile. A sua detenção ocorreu, conforme relato dela:

La empleada de migraciones retuvo los documentos de todos los pasajeros [...]. Durante una hora aprox. nos tenían a todos los pasajeros y el microbús no se [palavra ilegível]. Luego me llamaron aparte, me hicieron unas preguntas y me pidieron que reconozca mi equipaje. Lo revisaron en un cuarto aislado. De pronto me doy cuenta que el microbús había partido con el resto de pasajeros, en ese momento me llevan aparte, me desnudan, me encañonan con un revolver, me golpean e insultan. ${ }^{330}$

Depois disso, ela esteve presa, seguidamente, em três fazendas. Em várias ocasiões ficou algemada e enquanto era interrogada por agentes do Batalhão 601 escutava gritos de outros prisioneiros. ${ }^{331}$ Situação comum em prisões clandestinas, quem ouve a tortura alheia também está sendo torturado, por meio da tortura do outro, ao imaginar que certamente vai passar pela mesma situação. Do mesmo modo, em muitas sessões de tortura outros

\footnotetext{
${ }^{329}$ GRIMSON, A. La nación en sus límites - Contrabandistas y exilados en la frontera Argentina-Brasil. Barcelona: Editorial Gedisa S/A, 2003. p. 187.

${ }^{330}$ ARGENTINA. Primeira Instancia de Paso de los Libres/Corrientes. Ministério Público Federal. Waern, Carlos Fidel y otros s/ supuesta comisión delitos de lesa humanidad. Expediente $\mathbf{n}^{\mathbf{0}}: \mathbf{1 . 7 8 . 2 3 9 / 0 4}$. 28-0804. Fls. 1024.

${ }^{331}$ Ibidem, fls. 1025-1026.
} 
prisioneiros eram obrigados a assistir a violência praticada - há vários casos em que chamavam o companheiro de uma mulher e a estupravam na frente dele.

Nem todos os sequestrados passavam por tortura, principalmente os que aceitavam “colaborar" com a repressão. A colaboração poderia ser apenas informativa, participar de emboscadas para capturar antigos companheiros ou, como, Silvia, atuar na "marcação". Conforme seu depoimento à Subsecretaria de Direitos Humanos do Ministério do Interior da Argentina, ela conta o que tinha de fazer:

[...] me sentaban en una oficina de migraciones, me traían toda la documentación
de los pasajeros y con álbum de fotos me hacian reconocer gente. Durante todos los
meses que estuvo no hubo ningún secuestro en ese puesto [Paso de los Libres].
Prácticamente todos los vecinos sabian que yo era una detenida, puesto habian
pasado otros secuestrados en mis mismas condiciones.

No depoimento, Silvia diz que não houve sequestro enquanto ela esteve em Paso de los Libres, período compreendido entre julho de 1981 e março de 1982. Não se tem registros de desaparecimentos, porém não se pode afirmar que não ocorreu nenhum sequestro enquanto ela atuou em Paso de los Libres. Isto porque Silvia pode não ter tomado conhecimento - ela não era a única "marcadora" no local -, ou elegeu omitir essa informação. Caso tenha omitido, há a hipótese de fazê-lo por defesa, já que poderia ser acusada de participação e cumplicidade.

Os "marcadores" são culpabilizados de ambos os lados: pela repressão e pelos antigos companheiros. Pelos agente repressivos, muitos consideravam essas pessoas "fracas" e não confiáveis. Entre os antigos companheiros, a culpa atribuída era por não haver resistido. Dessa forma, ocorre uma dupla negação de dignidade. Em muitos relatos da CONADEP, está saliente a "falta de dignidade" de um "marcador". Em realidade, até os sobreviventes de uma prisão clandestina podem se culpar, pois sobreviveram enquanto milhares morreram - caso de Silvia, que além de sobreviver, casou-se com um dos repressores.

Sobre o local em que Silvia permanecia, o escritório de migração, abaixo na planta da aduana $^{333}$ identifica-se como era o caminho das pessoas que ingressavam no Brasil. Ônibus, automóveis e motos precisavam ocupar o único estacionamento do local. Então, as pessoas dirigiam-se para a área entre o Cuerpo $C$ e o Cuerpo $B$ para fazer os trâmites migratórios. Os

332 ARGENTINA. Primeira Instancia de Paso de los Libres/Corrientes. Ministério Público Federal. Waern, Carlos Fidel y otros s/ supuesta comisión delitos de lesa humanidad. Expediente no: 1.78.239/04. 28-0804. Fls. 1028.

${ }^{333}$ Essa planta baixa já está presente na tese, porem considerou-se importante repetir aqui pois é em um novo contexto, importante para compreender como funcionava a logística aduaneira. Essa planta é parte do acervo de documentos utilizados na dissertação de mestrado da autora desta tese. 
"marcadores" ficavam atrás do Cuerpo $C$ (indicado com um $\mathrm{X}$ na imagem). Como o estacionamento era cercado, não existia a possibilidade de desembarcar de um veículo sem passar em frente ao local que servia para a repressão.

Nesse mesmo prédio, ocorriam interrogatórios de detidos pela repressão, antes da utilização da fazenda La Polaca. Portanto, enquanto Silvia esteve ali, provavelmente não ocorreram torturas e interrogatórios no prédio em que ele atuava como "marcadora", pois já havia outro local para essa finalidade, a fazenda La Polaca.

Ao relatar sua estadia em Paso de los Libres, Silvia revela muitas informações importantes. Entre as pessoas com as quais ela afirma ter tido contato está "Turco Julian", corroborando com o depoimento de Carlos Fidel Waern: "Personal de Paso de los Libres: en el traslado y durante todo el destino en Paso de los Libres mes por medio. El Turco Julían cuyo nombre verdadero era Julio Simon [...]". ${ }^{334}$

As pesquisas de Nilson Mariano apontam que Silvia e "Turco Julian” viajaram para Paso de los Libres juntos em julho de 1981:

Em julho de 1981, Turco Julián e Silvia viajaram de avião de Buenos Aires a Libres, onde ela foi apresentada ao comandante do Destacamento 123 de Inteligência do Exército (o ramal do B. 601), tenente-coronel António Herminio Simón. Silvia foi hospedada numa casa na Rua Brasil, no lado argentino, a qual descreveu como "lúgubre". 335

Comprovada a presença de uma "marcadora" e de um dos mais renomados agentes da repressão na fronteira Uruguaiana-Paso de los Libres, entende-se que nesse local uma estrutura de prisão - sequestro - desaparecimento, típica do Operativo Murciélago e das atividades da Operação Condor, estava implementada.

Além de "Chela"/Silvia, ao menos outro "marcador" atuou nessa fronteira. Hector Amilcar Archetti chegou em janeiro de 1981, e quando Silvia foi embora ele continuou na cidade"336. "En setiembre de 1981 vuelven a traer Archetti a Paso de los Libres, donde estamos en la misma casa hasta que me trasladan en marzo de 1982, él permanece en Paso de los Libres". ${ }^{337}$ Archetti conforme a investigação em Paso de los Libres já havia atuado nesta fronteira. Hector, tinha como codinome "El Petiso”, advogado fundou a Agrupación de

\footnotetext{
${ }^{334}$ ARGENTINA. Primeira Instancia de Paso de los Libres/Corrientes. Ministério Público Federal. Waern, Carlos Fidel y otros s/ supuesta comisión delitos de lesa humanidad. Expediente no : 1.78.239/04. 28-0804. Fls. 1029.

${ }^{335}$ MARIANO, S. Nilson. Montoneros no Brasil - Terrorismo de Estado no seqüestro-desaparecimento de seis guerrilheiros argentinos. Porto Alegre: PUCRS, 2006. Dissertação, Mestrado em História - PUCRS. Porto Alegre, p. 84.

${ }^{336}$ ARGENTINA, op. cit., fl. 1027.

${ }^{337}$ Ibidem, fl. 1028.
} 
Abogados Peronistas de La Plata, atuava defendendo presos políticos, militante considerado do braço intelectual dos montoneros, realizava reuniões em sua casa. Se exilou no México e voltou para Argentina para atuar na contraofensiva montonera. Foi sequestrado aos 45 anos, em Las Cuevas - Mendoza no dia 20 de setembro de 1980, foi visto pela primeira vez após o sequestro na fronteira Uruguaiana-Paso de los Libres onde, segundo informações de agentes da repressão atuou como "marcador", também foi visto no centro de detenção clandestino Campo de Mayo. ${ }^{338}$

Silvia Tolchinsky, como os demais que colaboraram com a repressão, foi considerada traidora por muitos companheiros, não apenas por “entregar" militantes, mas também por ter casado com um agente da ditadura: Claudio Gustavo Sacgliussi, ex-agente civil do Batalhão 601.

\begin{abstract}
O infortúnio de Silvia Tolchinsky dividiu os Montoneros. Uns a culparam por ter servido de marcadora - uma covardia perante os que se suicidaram ingerindo a cápsula de cianureto para evitar o risco de não aguentar a tortura e se tornar um delator - e, especialmente, por haver se casado com um repressor. Outro grupo absolveu Silvia, considerando que ela foi uma das tantas vítimas do Terrorismo de Estado Argentino, uma prova viva de como a ditadura triturou corpos e mentes. ${ }^{339}$
\end{abstract}

O casal começou uma relação amorosa quando ela estava presa em uma das fazendas antes de ir para Paso de los Libres. Em 1982 quando foi libertada, fugiu com Claudio para Barcelona na Espanha. ${ }^{340}$ Seu marido foi acusado na causa "Scagliusi, Claudio y otros s/ privación ilegítima de la libertad"; entre outros delitos, Claudio é acusado de participar da operação que sequestrou Mónica Susana Pinus de Binstock, no Rio de Janeiro. Silvia era prima de Mónica.

\footnotetext{
${ }^{338}$ ARGENTINA. Expte. no 16307/06 Guerrieri Pascual Oscar y otros s/ Privación ilegal de la libertad personal' - JUZGADO NACIONAL EN LO CRIMINAL Y CORRECCIONAL FEDERAL No 4 - 18/12/2007. fl. 457. ${ }^{339}$ MARIANO, S. Nilson. Montoneros no Brasil - Terrorismo de Estado no seqüestro-desaparecimento de seis guerrilheiros argentinos. Porto Alegre: PUCRS, 2006. Dissertação, Mestrado em História - PUCRS. Porto Alegre, p. 86.

${ }^{340}$ MITCHELL, José. Segredos à direita e à esquerda na ditadura militar. Porto Alegre: RBS Publicações, 2007. p. 106-107.
} 


\subsection{Turco Julian: o senhor da morte}

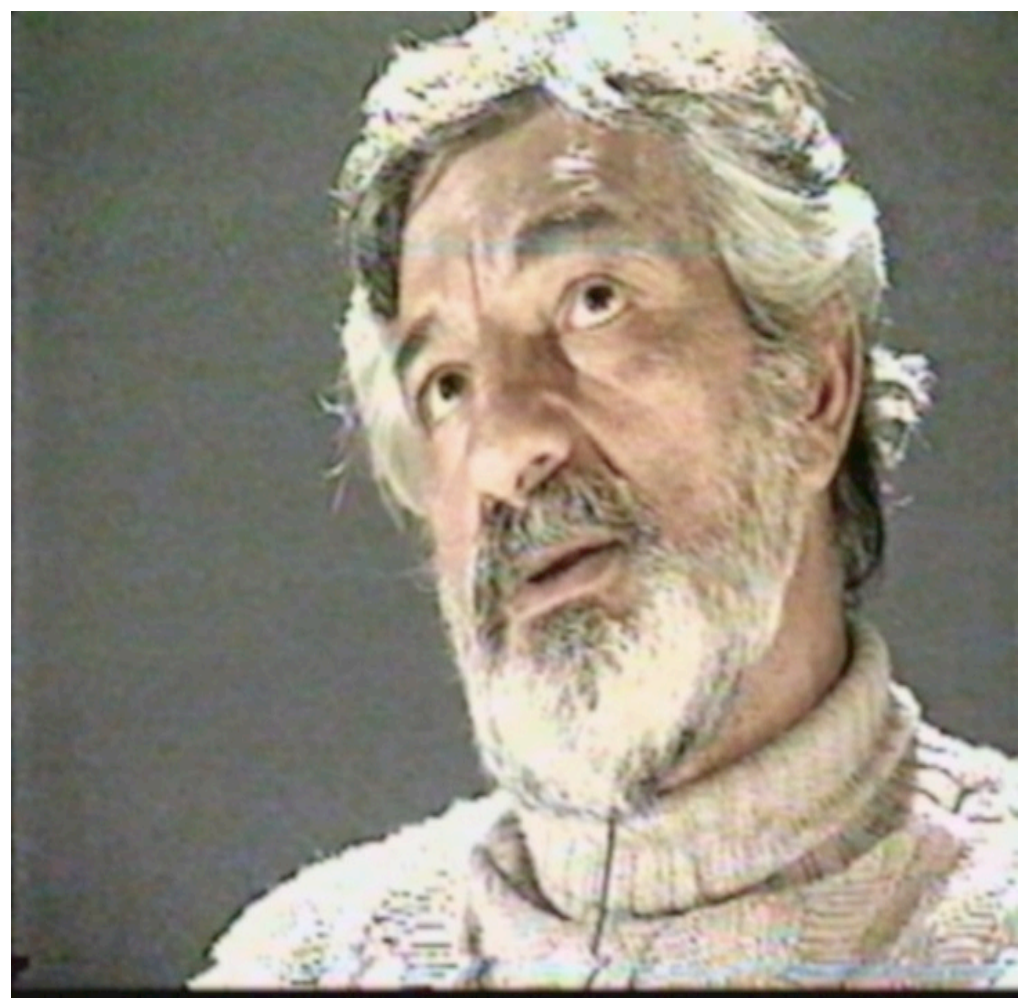

Figura 8 - Júlio Héctor Simon - "El turco Julían"

Fonte: Banco de dados Perfil.com (2013).

Os especialistas em repressão atuavam em diversos locais. Era comum passarem temporadas em cidades/prisões clandestinas para treinar outros agentes ou para intensificar as atividades de sequestro, tortura e desaparecimento. Eram chamados conforme a "necessidade", ou seja, a avaliação de que em determinado local um especialista seria útil. Julio Héctor Símon, o “Turco Julían”, passou por inúmeras prisões clandestinas na Argentina.

Antes de ser agente do Batalhão 601, foi policial federal. Conhecido também como "Senhor da morte", admitiu que torturou e matou pessoas durante sua passagem pelo B 601. ${ }^{341}$ Confome Mariano: "Turco Julían foi um dos mais abnegados repressores, assumindo as vilanias que a atividade pressupunha naquele contexto de Terrorismo de Estado",342.

\footnotetext{
${ }^{341}$ MARIANO, S. Nilson. Montoneros no Brasil - Terrorismo de Estado no seqüestro-desaparecimento de seis guerrilheiros argentinos. Porto Alegre: PUCRS, 2006. Dissertação, Mestrado em História - PUCRS. Porto Alegre, p. 51-54.

${ }^{342}$ Ibidenm, p. 53.
} 
Carlos Fidel Waern o cita em seu depoimento como um dos mais dedicados agentes. Também é lembrado por outras pessoas que declararam na causa "La Polaca"343, como Gabriel Link. Este ex-militar relatou que via civis e militares saindo do Destacamento em carros, aparentemente em comitivas e afirma recordar-se "claramente" que el "Turco Julían" entraba a la madrugada habitualmente a cambiar las patentes de un auto, que esta persona era sin duda quién mayor poder tenia sobre el jefe del Destacamento „344, ele era o único que, antes de entrar, não precisava bater na porta do escritorio do chefe, demonstrando sua influencia na estrutura repressiva na região fronteiriça.

O responsável pela ponte internacional, Pedro Augustín Pasteris, tinha conhecimento dos interrogatórios em um escritório no prédio da Aduana. $\mathrm{O}$ escritório era utilizado por três ou quatro civis, homens e mulheres, e entre esses havia um homem conhecido como "el Turco”, que ademais do escritório também circulava pelos escritórios da Gendarmeria, Sanidad. Mais tarde, Pedro soube que este homem era "Turco Julían", 345 Já Ruben Oscar Guardiola executava tarefas na Aduana e declarou ter conhecido Turco Julián, no escritório das forças armadas, en el inverno de 1981 le mostraron a una persona que le dijeron se trataba del "Turco Julian", circulaba por todos lados, andaba armado y se jactaba de ello. $^{346}$

$\mathrm{Na}$ aduana circulavam (e ainda circulam) muitas crianças pedindo esmolas, devido ao fluxo permanente de pessoas no local. Guardiola contou que em uma tarde de inverno rigoroso, Julían doou a sua própria jaqueta para um desses meninos. Ele também comentou que o repressor tinha uma postura arrogante, mas gostava de contar piadas e rir com pessoas que trabalhavam com ele e até com funcionários de outras repartições. ${ }^{347}$ Turco Julian tinha uma vida cotidiana comum, muito parecida com as de outras pessoas com quem convivia, grande parte sem saber que ele era um torturador. Um comportamento normal e cotidiano e que, de maneira nenhuma, arrefece suas atividades enquanto torturador. Segundo Sarlo, vários repressores nazistas que assassinavam judeus, ao retornar para casa ao fim do dia "ouviam

${ }^{343}$ Devido a peculiaridade dos casos tratados nessa Tese e da importância de alguns depoimentos e passagens, considerou-se relevante usar documentos da dissertação de mestrado, e discutir também na Tese de doutorado pautas que estiveram presentes em trabalho anterior da autora, para melhor entendimento das experiências analisadas nesta Tese. Dessa forma, foram repetidas partes de depoimentos, presentes na dissertação de mestrado da autora desta Tese, que são importantes para entender o contexto e a inserção de determinados agentes. Essa repetição de fontes se dá, por não haver outras disponíveis nos acervos pesquisados pela autora.

344 ARGENTINA. Primeira Instancia de Paso de los Libres/Corrientes. Ministério Público Federal. Waern, Carlos Fidel y otros s/ supuesta comisión delitos de lesa humanidad. Expediente no: 1.78.239/04. 28-0804. Fls. 579.

345 Ibidem, fl. 1323.

${ }^{346}$ Idem, fl. 2371.

${ }^{347}$ Idem, fl. 2372. 
uma sinfonia de Beethoven regida por Wilhelm Furtwängler e cobriam seus filhos de carinho". ${ }^{348}$ A maioria dos torturadores, em qualquer lugar, tem uma vida normal, constituem famílias, participam de atividades na comunidade em que estão inseridos. "Um sujeito ser, ao mesmo tempo, um assassino e um bom pai não é um fato incomum"349.

O modo de ser de Turco Julían em público, não atenua suas atividades criminosas. Ao mesmo tempo que era um "contador de piadas" e sensibilizava-se com meninos carentes, foi um torturador. Além da acusação na investigação em Paso de los Libres, ele foi réu e condenado em outra causa: "Simón, Julio Hector y otros s/ privación ilegítima de la libertad, etc. - causa $\mathrm{N}^{\mathrm{o}} 17.768$ ".

Os delitos cometidos por ele foram crime contra a humanidade, privação ilegal de liberdade duplamente agravada por violência e ameaças e tormentos agravados cometidos contra perseguidos políticos. Segundo consta na apelação de sua defesa em 14 de junho de 2005, a Justiça afirma que Turco Julían:

[...] haber secuestrado en la tarde del 27 de noviembre de 1978 a José Liborio Poblete Rosa en la Plaza Miserere [Buenos Aires] y en horas de la noche, a la esposa de este, Gertrudis Marta Hlaczik, y a la hija de ambos, Claudia Victoria Poblete [...]. Todos ellos fueron llevados al centro clandestino de detención conocido como "El Olimpo", donde el matrimonio[refere ao casal sequestrado] fue torturado por distintas personas entre las que se encontraba Simón. Allí permanecieron unos dos meses, hasta que fueron sacados del lugar, sin tenerse, hasta ahora, noticias de su paradero. ${ }^{350}$

Jair Krischke ${ }^{351}$ conta mais sobre as atividades do "Senhor da Morte":

Que por las conexiones que tenían los Derechos Humanos de Brasil y Argentina, tomaron conocimiento de la existencia de una persona que se hacía llamar el "Turco Julian", que integraba un grupo de tareas, popularmente denominado "patota", que esta se dedicaba a la represión especialmente "marcador" en esta región con esta función. [...] que tenían la inquietud de tomar fotos de esta persona $y$ entrevistarse con él y si lograban con las autoridades brasileñas su detención, enterándose que era custodia de un curandero brasileño famoso llamado

"Garrincha", además se enteran que tenia una novia en un prostíbulo con la que se

\footnotetext{
${ }^{348}$ SARLO, Beatriz. Tempo presente: notas sobre a mudança de uma cultura. Rio de Janeiro: José Olympio, 2005. P. 164.

${ }^{349}$ Ibidem, p. 164.

${ }^{350}$ PROCURADORIA GERAL DA NAÇÃO - SUPREMA CORTE. Recurso de hecho: Simón, Julio Héctor y otros s/ provación ilegítima de la libertad, etc. - causa $\mathbf{N}^{0}$ 17.768. 14-06-2005. f. 01-02.

${ }^{351}$ Jair Krischke é advogado e ex-presidente do Movimento de Justiça e Direitos Humanos, "organizou uma rede solidária de igrejas, ordens religiosas, colégios e outros locais de esconderijos, ajudou a salvar um grande número de uruguaios e argentinos". Cf. MITCHELL, José. Segredos à direita e à esquerda na ditadura militar. Porto Alegre: RBS Publicações, 2007.
} 
entrevistaron, razón por la cual se entera que el Turco Julian decide venir a vivir a Paso de los Libres. ${ }^{352}$

Mariano acrescenta que Julío Héctor Simón atuou na prisão clandestina El Atlético, localizada em San Telmo, bairro de Buenos Aires. Essa prisão era conhecida por atuação de repressores anti-semitas; conforme o autor, Julian era um deles: "Ele gostava de torturar judeus ao som de marchas nazistas. Nos anos 80, foi guarda-costas do brasileiro Carlos Eustáquio Barbosa, o Garrincha, que atraiu multidões na cidade de Uruguaiana [...] prometendo curas milagrosas. ${ }^{353}$

Após o fim do golpe na Argentina, em 1983, Julían foi viver em Uruguaiana, e trabalhava como guarda-costas do médium Garrincha:

Numerosos tours ofrecian viaje, alojamiento y la visita al manosanta. Recibía unos
1500 peregrinos por día y cobraba la atención. Como todos los de su profesión
generó polémicas y despertó veneración y adhesiones incondicionales. Fue
calificado de santo y de charlatán. En 1985 se instala en Buenos Aires, en un
galpón en la calle Avellaneda 1473 , en el barrio de Caballito y continúa
atendiendo. Ahora los avisos en los diarios ofrecen "Garrincha. Seminarios y
conferencias sobre la doctrina Espiritista fundada por Allan Kardec. Inscripción
limitada". La policía lo detuvo y fue entonces que fundó una entidad denominada
"Sendero de Fe" y la inscribió en el Registro Nacional de Culto, y ya no tuvo más
problemas con la ley.

A passagem desse agente da repressão por Uruguaiana, durante e depois do golpe argentino, é emblemática - primeiro como agente da repressão, e depois como segurança de uma das figuras "mais famosas" e polêmicas de Uruguaiana.

352 ARGENTINA. Primeira Instancia de Paso de los Libres/Corrientes. Ministério Público Federal. Waern, Carlos Fidel y otros s/ supuesta comisión delitos de lesa humanidad. Expediente no: 1.78.239/04. 28-0804. Fls. 630.

353 MARIANO, S. Nilson. As garras do Condor: como as ditaduras militares da Argentina, do Chile, do Uruguai, do Brasil, da Bolívia e do Paraguai se associaram para eliminar adversários políticos. Petrópolis, RJ: Vozes, 2003. p. 45.

${ }^{354}$ Disponível em: http://www.cuco.com.ar/garrincha.htm 


\subsection{Lorenzo Ismael Viñas}

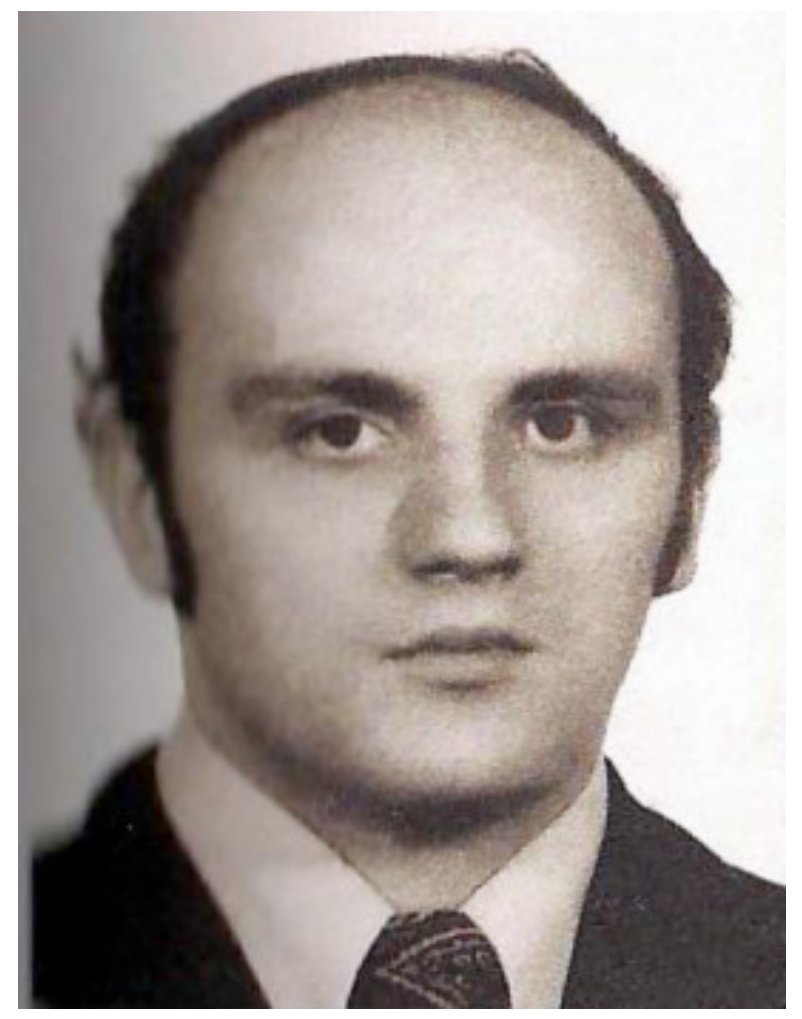

Figura 9 - Lorenzo Ismael Viñas.

Fonte: Arquivo Nacional (2013).

26 de junio de 1980, iban a viajar juntamente con su hija a la ciudad de Rio de Janeiro, a último momento Lorenzo le disse qye no es conveniente viajar con su pequena hija, ya que la nena tenía 26 días, Lorenzo viaja solo y con documento falso, con el nombre de Néstor Manuel Ayala. ${ }^{355}$

Lorenzo Ismael Viñas desapareceu quando fugia da Argentina - sua intenção era chegar na Europa, para isso viajou de Buenos Aires com destino ao Rio de Janeiro em junho de 1980. Como muitos, não conseguiu terminar a viagem. Lorenzo tinha 25 anos quando desapareceu, e era estudante universitário. Sua família militava: seu pai David Viñas era um escritor muito conhecido e estava exilado na Espanha em 1980, e sua irmã Maria Adelaida Viñas desapareceu em 1976 junto com seu companheiro Carlos Andres Goldemberg.

A esposa de Lorenzo, Claudia Olga Allegrini, prestou depoimento na causa que investigava se a estância La Polaca foi uma prisão clandestina, pois como Lorenzo desapareceu entre Paso de los Libres e Uruguaiana é possível que tenha passado por este

355 ARGENTINA. Primeira Instancia de Paso de los Libres/Corrientes. Ministério Público Federal. Waern, Carlos Fidel y otros s/ supuesta comisión delitos de lesa humanidad. Expediente $\mathbf{n}^{\mathbf{0}}$ : 1.78.239/04. 28-0804. Fls. 631. 
chupadero. Em seu depoimento, Cláudia conta que Lorenzo era militante peronista na Juventude Universitária Peronista. Em 14 de novembro de 1974 foi preso, e quando libertado foi para o México junto com Cláudia. Já em 1977, os Montoneros convidaram o casal para voltar; os dois passaram dois anos no Brasil e em junho de 1979 ingressaram na Argentina por Foz do Iguaçu. A família de Claudia vivia na cidade de Paraná-Entre Rios - assim que chegaram em Buenos Aires eles foram para a casa dos familiares de Cláudia, que ficou grávida. A filha do Lorenzo, Maria Paula, nasceu no dia 20 de maio de $1980 .{ }^{356}$

Conforme a Comissão especial sobre Mortos e Desaparecidos Políticos, Lorenzo pretendia morar na Itália. Embarcou em um ônibus da empresa Pluma com destino ao Rio de Janeiro, no dia 26 de junho de 1980, quando desapareceu. Sua esposa Cláudia viajou para o Rio de Janeiro como tinham combinado, mas não encontrou Lorenzo. Passou a buscar informações, e a empresa Pluma lhe disse que Lorenzo havia embarcado mas não passou de Uruguaiana. ${ }^{357}$

Alguns autores já trataram do caso de desaparecimento de Lorenzo Ismael Viñas. Mariano afirma que Lorenzo viajou no ônibus da Pluma número 7825, com bilhete 93.304 e sua poltrona era de número $11^{358}$. Mariano entrevistou a esposa de Lorenzo e trata do caso no seu livro e na sua dissertação de mestrado ${ }^{359}$. Fernandez, em sua tese de doutorado, que tem como objeto de estudo os argentinos exilados no Brasil, comenta o caso de Lorenzo. Esse autor trabalha com a hipótese de que os órgãos da repressão podem ter obtido informações na empresa de ônibus, pois sabiam muitos detalhes acerca da viagem dos considerados "subversivos". 360

Já Mitchell entrevistou José Antônio Hahn, diretor da Polícia Federal em Uruguaiana quando do sequestro de Lorenzo, portanto contempla outra perspectiva sobre o caso. O delegado nega que o sequestro tenha ocorrido em Uruguaiana ou que tenha acontecido colaboração entre as instituições de segurança na fronteira, "Ele [Hahn] rejeita a acusação

${ }^{356}$ ARGENTINA. Primeira Instancia de Paso de los Libres/Corrientes. Ministério Público Federal. Waern, Carlos Fidel y otros s/ supuesta comisión delitos de lesa humanidad. Expediente $\mathbf{n}^{\circ}$ : 1.78.239/04. 28-0804. Fls. 631.

${ }^{357}$ BRASIL. Secretaria Especial dos Direitos Humanos. Comissão Especial sobre Mortos e Desaparecidos Políticos. Direito à verdade e à memória: Comissão Especial sobre Mortos e Desaparecidos Políticos. Brasília: Secretaria Especial dos Direitos Humanos, 2007. p.441.

${ }^{358}$ MARIANO, S. Nilson. As garras do Condor: como as ditaduras militares da Argentina, do Chile, do Uruguai, do Brasil, da Bolívia e do Paraguai se associaram para eliminar adversários políticos. Petrópolis, RJ: Vozes, 2003. p. 71.

359 Ibidem. Montoneros no Brasil - Terrorismo de Estado no seqüestro-desaparecimento de seis guerrilheiros argentinos. Porto Alegre: PUCRS, 2006. Dissertação, Mestrado em História - PUCRS. Porto Alegre, 2006.

${ }^{360}$ FERNANDEZ, Jorge C. Anclaos en Brasil: a presença argentina no Rio Grande do Sul (1966-1989). Porto Alegre: UFRGS, 2011 Tese (Doutorado em História) - Programa de Pós-Graduação em História da UFRGS. Universidade Federal do Rio Grande do Sul, Porto Alegre, 2011. 
contra os militares porque era o responsável pela segurança na fronteira em Uruguaiana e garante que ninguém, nem os militares, teria coragem de praticar um sequestro na sua área, sem sua autorização"361. Ao mesmo tempo, nega este acontecimento, ou seria responsabilizado.

Para tratar do presente caso, esta Tese se fundamenta no processo da esposa de Lorenzo, Cláudia Allegrini, e da filha Maria Paula Viñas, na Comissão Especial de Mortos e Desaparecidos Políticos da Secretaria de Direitos Humanos da Presidência da República; nos documentos da CONADEP; no inquérito da Polícia Federal em Uruguaiana sobre ocorrências repressivas na última ditadura em Uruguaiana; e também nos processos argentinos "Riveros, Santiago Omar y otros por la privación ilegal de la libertad, tormentos, homicídio e etc. do Juzgado Federal en lo criminal y correlacional no 2 de San Martín" e "Scagliusi, Claudio y otros s/ privación ilegítima de la libertad”. Estes últimos com documentos inéditos acerca do caso.

${ }^{361}$ MITCHELL, José. Segredos à direita e à esquerda na ditadura militar. Porto Alegre: RBS Publicações, 2007. p. 104. 


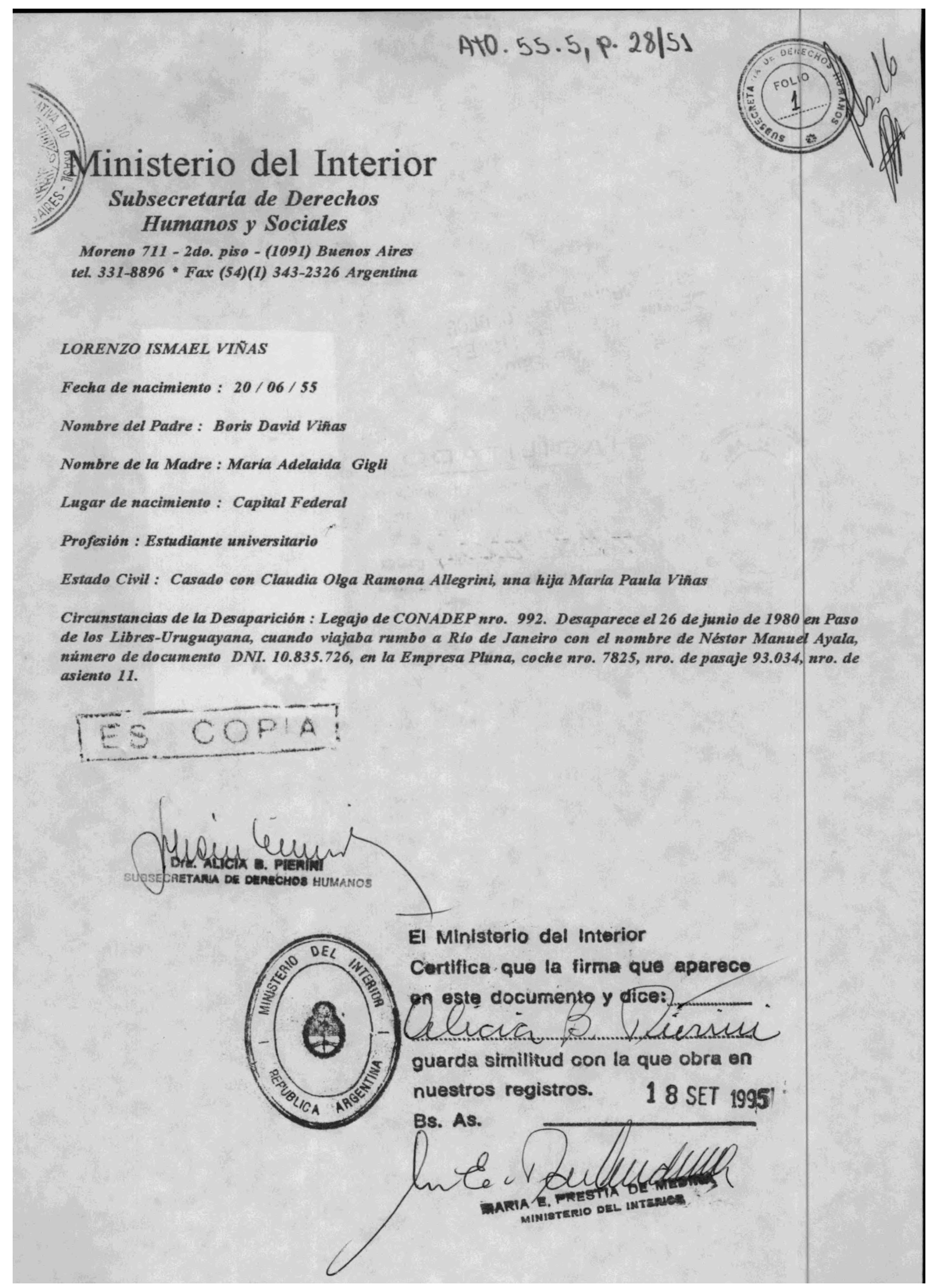

Figura 10 - Ficha de Lorenzo Ismael Viñas.

Fonte: Arquivo CONADEP (1995). 
Conforme o depoimento dado na CONADEP por sua companheira Claudia, Lorenzo desapareceu em Uruguaiana, já que ela, quando foi procurá-lo no Brasil, obteve a informação da empresa Pluma que ele "passou" a fronteira.

A volta de Lorenzo e Cláudia para a Argentina em 1979 ocorreu por conta da contraofensiva montonera, porém após o nascimento de Maria Paula a situação se tornou insustentável. Com plano de fugir para a Europa, Lorenzo combinou de viajar para o Rio de Janeiro separado de Cláudia. Foi o que fez, como destacado no seu processo na CONADEP. Viajou no dia 26 de junho de 1980, e desapareceu em Uruguaiana. O Estado brasileiro reconheceu seu desaparecimento em 2005, quando sua família foi indenizada.

O delegado Hahn enviou uma carta para a Comissão Especial sobre Mortos e Desaparecidos Políticos contestando essa decisão. Ele sugere que o pedido foi feito tendo em vista apenas aspectos financeiros, e que a família teria dito que o desaparecimento ocorreu em Uruguaiana pois o Brasil paga indenizações. Segundo Hahn:

Quero informar que, na época, ano de 1979 a 1981 , eu era o servidor público
responsável pelo controle da entrada de todos os passageiros de ônibus que
ingressaram no país pela ponte internacional que liga Paso de los Libres e
Uruguaiana. Tão logo surgiu a notícia do sequestro de Viñas, supostamente em
Uruguaiana, passei a investigar a hipótese com intensidade e afinco. Nenhuma pista
foi encontrada de que Lorenzo Ismael Viñas tivesse entrado no Brasil, do ônibus,
por Uruguaiana. ${ }^{362}$

O que chama atenção na fala do delegado aposentado é ele declarar que investigou com afinco e intensidade o caso e não ter averiguado com a empresa Pluma sobre a viagem de Lorenzo. Afinal, Cláudia, ao indagar à empresa sobre o assunto, foi informada de que Lorenzo atravessou a fronteira, mas não passou de Uruguaiana.

Em 2008, a Procuradoria da República em Uruguaiana, por meio do Procurador Ivan Cláudio Marx, solicitou à Polícia Federal que investigasse sobre ocorrências repressivas em Uruguaiana e Paso de los Libres. Entre os testemunhos acerca do caso de Lorenzo, há o de Jair Krischke:

[...] Lorenzo saí de Santa Fé rumo ao Rio de Janeiro no ônibus da empresa brasileira Pluma, veículo $n^{\circ} 7825$, passagem $n^{\circ} 93.034$, assento $n^{\circ} 11$; QUE portando a cédula de identidade $\mathrm{n}^{\mathrm{o}}$ 10.835.726 em nome de Nestor Manoel Ayala; QUE é nesse trajeto que Lorenzo Ismael Viñas desaparece; QUE isso fica claro no processo aberto em Buenos Aires, na sentença do Dr. Cláudio Bonadio, Juiz Federal Argentino, quando se reporta: "Y se cree que desapareció en el cruce fronterizo... presumiblemente del

\footnotetext{
${ }^{362}$ Brasil. BR_DFANBSB_ATO_0055_0006. Assunto: Lorenzo Ismael Viñas. Folha 170.
} 
lado brasileño, dado que la empresa de colectivos mencionada informó que según sus registros la víctima habia cruzado la frontera". ${ }^{363}$

Fato dado entre todos os pesquisadores acerca do tema é que Lorenzo desapareceu na fronteira de Uruguaiana e Paso de los Libres. Apesar do ex-delegado Hahn negar veementemente que o sequestro ocorreu em Uruguaiana, os indícios apontam que Lorenzo foi sequestrado em uma operação típica do Condor e nesta fronteira. Conforme o relatório final da Comissão Nacional da Verdade:

LOCAL DE DESAPARECIMENTO E MORTE

Entre Paso de los Libres e Uruguaiana, fronteira Brasil-Argentina. IDENTIFICAÇÃO DA AUTORIA

1. CADEIA DE COMANDO DO(S) ÓRGÃO(S) ENVOLVIDO(S) NO DESAPARECIMENTO E NA MORTE 1.1. CENTRO DE INFORMAÇÕES DO EXÉRCITO (CIE)

Presidente da República do Brasil: general de Exército João Figueiredo Ministro do Exército: general de Exército Walter de Albuquerque Pires Chefe do CIE: general de Brigada Geraldo Araújo de Ferreira Braga Comandante do III Exército: general de Exército Antonio Bandeira

Chefe do Estado-Maior do III Exército: general de Brigada Henrique Domingues 1.2. SERVIÇO NACIONAL DE INFORMAÇÕES (SNI)

Presidente da República do Brasil: general de Exército João Figueiredo Ministro do Exército: general de Exército Walter de Albuquerque Pires Chefe do SNI: general de Brigada Octávio Aguiar de Medeiros Chefe da Agência do SNI em Porto Alegre: coronel Carlos Alberto Ponzi. ${ }^{364}$

Em 1994, Silvia Noemi Tolchinksy enviou uma carta para Claudia, na qual afirma ter encontrado com Lorenzo em três ocasiões. No primeiro encontro entre Silvia e Lorenzo, estavam os dois presos na mesma sala, e ele contou que estava neste local havia mais de 90 dias, mostrou fotos de sua filha e dizia estar muito preocupado com sua esposa. Conta também que Lorenzo foi torturado violentamente e resistira. Um segundo encontro aconteceu em uma espécie de refeitório, onde Lorenzo voltou a falar da esposa e da filha. O terceiro e derradeiro encontro aconteceu quando ele estava sendo "transladado", Silvia diz que ele parecia contente e que ela estava convencida de que iam matá-lo, apesar de ser dito que ele ia ser liberado; esta foi a última vez que Silvia viu Lorenzo. Na mesma carta que ela enviou para Claudia, ela diz acreditar ter visto o padre Jorge Adur. Não confirma, pois devido a aparência

\footnotetext{
${ }^{363}$ Serviço Público Federal. MJ-Departamento de Polícia Federal Delegacia de Polícia Federal em Uruguaiana DPF/UGA/RS. Inquérito policial: 0116/2008-4-DPF/UGA/RS. Folha 170. 22/06/2009.

${ }^{364}$ BRASIL. Relatório Comissão Nacional da Verdade (CNV). Volume III Mortos e desaparecidos politicos. Brasília: Comissão Nacional da Verdade, 2014. p. 1957.
} 
e as perguntas que foram feitas à pessoa que ela acredita ser o padre não pode ter certeza, assim como tem certeza de que esteve com Lorenzo. ${ }^{365}$

Silvia chegou em Paso de los Libres em julho de 1981. Ela não cita a data exata em que encontrou com Lorenzo, que desapareceu em junho de 1980. Diante deste quadro, se o primeiro encontro ocorreu logo que Silvia chegou na fronteira Uruguaiana-Paso de los Libres, então Lorenzo permaneceu vivo por mais de um ano. Considerando que ele disse estar no local por mais de três meses, pode-se concluir que Lorenzo foi sequestrado na fronteira, transladado para outro, ou outros locais, e depois retornado para Paso de los Libres, onde foi visto pela última vez.

\subsection{Padre Jorge Oscar Adur}

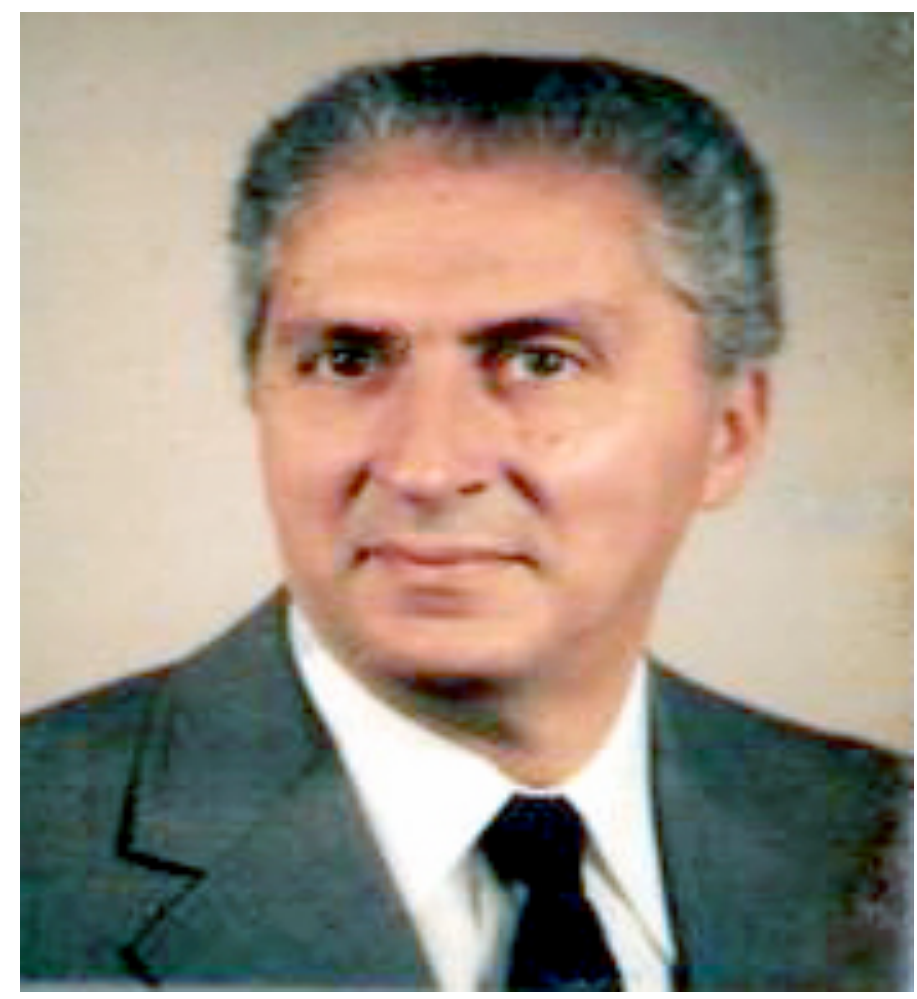

Figura 11 - Padre Jorge Oscar Adur.

Fonte: Arquivo Nacional (2013).

Dentro dos montoneros, havia um grupo ligado à Igreja católica, e entre seus dirigentes havia homens que debatiam com a alta hierarquia: Firmenich, Montoro, Perdía e Roberto Mendizábal, entre outros que vieram, principalmente, do grupo Descamisados. É

365 MARIANO, S. Nilson. As garras do Condor: como as ditaduras militares da Argentina, do Chile, do Uruguai, do Brasil, da Bolívia e do Paraguai se associaram para eliminar adversários políticos. Petrópolis, RJ: Vozes, 2003. p. 74-78. 
sabido que a cúpula católica na Argentina tinha ligações com a ditadura, e provavelmente por isso nunca respondeu aos pedidos de diálogo e tentativa de pacificação proposto pelos montoneros. Porém, era parte do projeto da contraofensiva montonera contar com apoio desta instituição religiosa, pois já tinham enviado cartas ao Papa João Paulo II, e:

[...] se aventuraron aun más: enviaron una carta al cardenal Jean Villot, secretario de Estado del Vaticano [...] para animar a los católicos a unirse al Ejército Montonero; este (sin ser entidad confesional) había establecido una capellanía y designado al padre Jorge Adur como capellán de la misma. ${ }^{366}$

Jorge Oscar Adur nasceu em Nogoyá, Entre Rios, em 19 de março de 1932. Estudou na Escuela Apostólica de Religiosos Asuncioistas de Olivos em Buenos Aires. Estudou também filosofia e teologia, em 1970 fundou Juventudes Independientes Católicas e se uniu ao Sacerdotes do Terceiro Mundo. Adur trabalhava na capital Buenos Aires e em Olivos, e era admirado pelo jovens montoneros. Considerado esquerdista, sua situação ficou insustentável após o golpe. O seminário onde atuava foi invadido em julho de 1976, e dois seminaristas foram levados, contando ainda hoje na lista de desaparecidos: Raul Eduardo Rodríguez e Antonio Di Pietro. ${ }^{367}$

Padre Adur foi para a França, passando por Roma, com ajuda do Monsenhor Pío Laghi, em julho de 1976. Em Paris, denunciava as violações aos direitos humanos ocorridas na Argentina. Em 1978 foi declarado capelão dos montoneros e uma carta sua foi publicada na revista "Estrella Federal":

\begin{abstract}
Carta al pueblo argentino
En esta carta quiera hacerles participes de mi decisión de asumir, personal y públicamente, la capellanía del Ejército Montonero y responder, así, al pedido expreso de su comandancia [...] Pero es también, y sobre todo, la Iglesia que busca la justicia y lo debe practicar lo que me lleva a mostrar a mi pueblo mi voluntad irrenunciable de acompañar a aquellos que asumen, integralmente, la lucha por la liberación de nuestra querida patria. Pongo entonces, mi sacerdocio y mi vida religiosa en la Iglesia al servicio de todos, porque la más alta expresión de la caridad a la cual tendemos los cristianos se expresa en la política, como un instrumento social exigido por la justicia. Este servicio es junto a aquellos que se entregan con la mas alta abnegación y enfrentando heroicos riesgos. ${ }^{368}$
\end{abstract}

366 TARRUELA, Alejandro C. El largo adiós de los montoneros: de las sombras de los setenta al presente kirchnerista. Buenos Aires: Javier Vergara Editor, 2012. p. 78-79.

${ }^{367}$ Cf. MARIANO, S. Nilson. As garras do Condor: como as ditaduras militares da Argentina, do Chile, do Uruguai, do Brasil, da Bolívia e do Paraguai se associaram para eliminar adversários políticos. Petrópolis, RJ: Vozes, 2003. Cf. TARRUELA, op. cit. Cf. HERNANDEZ, 2011.

${ }^{368}$ Los desastres en que la dictadura ha sumergido al país ya inundan los despachos militares. Revista Estrella Federal, n. 5, p. 25, set. 1978. 
Maria Aracelia Adur, irmã de Jorge, ingressou, em 1996, com um processo de indenização na Comissão Especial sobre Mortos e Desaparecidos Políticos brasileira, e teve seu pedido deferido no ano seguinte. Desde então, o padre Adur foi reconhecido pelo Estado brasileiro como desaparecido político. Nos documentos que fazem parte do processo, consta que no final de junho de 1980 Adur entrou em contato com sua irmã na Argentina, marcando um encontro com ela no Rio de Janeiro - ele pretendia encontrar o Papa João Paulo II, que estaria em visita ao Brasil.

Jorge Oscar Adur não foi direto ao Rio de Janeiro para encontrar sua irmã. Henandez aponta o trajeto feito por ele:

Logo no início de junho de 1980 , Adur, alistado na COE [contraofensiva montonera
no exterior], retornou clandestino para a Argentina, usando uma técnica que os
Montoneros chamavam de contraseguimiento e que visava despistar possíveis
inimigos no seu encalço. Assim, vindo de Paris, Adur desembarca em São Paulo, de
onde seguiria por via terrestre para Porto Alegre, Passo Fundo para, finalmente,
passar a fronteira com a Argentina na região do Alto Uruguai. ${ }^{369}$

Já em Buenos Aires, não avisou sua irmã que estava na Argentina. Por medida de segurança, ele ficou entre 10 e 14 dias na Argentina até se dirigir para Porto Alegre. Iria de ônibus até a capital gaúcha e de lá para o Rio de Janeiro. Maria Aracelia Adur conta que esperou por ele sete dias, mas ele não apareceu. Jorge saiu de Buenos Aires na noite de 26 de junho de 1980, embarcou em um ônibus da empresa General Urquiza usando documento falso em nome de Pedro Ramón Altamirano, número 4.066.191, mas nunca chegou ao destino ${ }^{370}$.

Jorge Oscar Adur não era vigiado somente na Argentina, suas correspondências eram interceptadas e, possivelmente seus disfarces conhecidos. Nas pesquisas no Arquivo Nacional, a autora desta Tese encontrou documento do SNI, datado de pouco mais de dois meses antes de seu sequestro/desaparecimento, com o seguinte teor:

Assunto: Atuação de subversivo estrangeiro

Funcionário da Cúria Arquidiocesana de São Paulo, comentou, em 17 de abril de 1980, ter D. Paulo Evaristo Arns recebido um telex do México, assinado pelo Capelão do Movimento Peronista Montonero R P Jorge Oscar Adur.

Solicita, segundo o funcionário, a colaboração de D. Paulo para esclarecer e denunciar o desaparecimento do dirigente do peronismo montonero Horácio Campiglia e de Susana Pinos, de Morstoque (?), que teria ocorrido em 11 de março de 1980 , no trajeto Panamá para o Rio de Janeiro, via Caracas. ${ }^{371}$

\footnotetext{
${ }^{369}$ HERNANDEZ, 2011. p. 394.

370 BRASIL. BR_DF_ANBSB_ATO_0048_0005. Interessado Maria Aracelia Adur. Assunto: Jorge Oscar Adur/Argentina. Arquivo Nacional. 1997. Folha 125.

${ }^{371}$ BRASIL. AC_ACE_70407_80. Assunto: atuação de subversivo estrangeiro. 18 de abril de 1978. Folha 2.
} 
O nome correto de Susana é Mónica Suzana Pinus de Binstock, militante montonera, prima de Silvia Noemi Tolchinsky. Horácio e Suzana foram presos em uma operação do Plano Condor no Rio de Janeiro, ao desembarcar no aeroporto internacional - eles vinham do México e pretendiam viver no Brasil, segundo o relatório da $\mathrm{CNV}$, as investigações conluíram que Mónica desapareceu em 12 de março de 1980 no Rio de Janeiro, ao desembarcar. Seu desaparecimento foi classificado pela CNV nas atividades da Operação Condor.

A instituição de um capelão para o Ejército Montonero era para além do cunho espiritual - era um papel político. Jorge Adur era um militante conhecido e atuante, mas talvez não estivesse ciente do quão amalgamadas estavam as ditaduras do Cone Sul, e dos sérios riscos que corria em suas viagens. Mesmo na clandestinidade, com documentos falsos, vários militantes foram pegos. Sobre a atuação do padre Adur,

Nosotros creamos en 1978 la figura de la Capellanía en el Ejército Montoneros con
una finalidad política. La idea principal tenía que ver con una gestión que
estábamos haciendo para lograr el reconocimiento como fuerza beligerante por
parte de Naciones Unidas. Planteábamos que desde ese lugar podiamos llegar a
discutir el tema de los presos en la Argentina. ${ }^{372}$

Padre Jorge Adur não participou de operações militares, não era esse o objetivo de um capelão. Adur era parte orgânica do projeto montonero da contraofensiva. Um projeto que não deu certo como um todo,

El padre Adur no se incorporó como un militante montonero; él se incorporó como capellán con el permiso y consentimiento de su orden, que era la Congregación de los Padres de la Asunción. Él no se clandestinizó, el superior de su orden lo autorizó formalmente. Él celebró misas con grupos de compañeros. ${ }^{373}$

Acerca das circunstâncias do desaparecimento de Adur, na causa "Riveros, Santiago Omar y otros por la privación ilegal de la libertad, tormentos, homicídio e etc." foi utilizada uma lista de passageiros fornecida pela empresa Urquiza. Tal lista continha os dados de quem viajava no mesmo dia e horário que Adur. Esta lista comprova que Adur, usando sua identidade falsa de Pedro Ramón Altamirano, embarcou no ônibus da empresa e sua poltrona era a $11 . .^{374}$

\footnotetext{
${ }^{372}$ WORNAT, Olga. Nuestra Santa Madre: historia pública y privada de la Iglesia Católica argentina. Buenos Aires: Ediciones B, 2002. p. 69.

${ }^{373}$ Ibidem, p. 68.

${ }^{374}$ ARGENTINA. Juzgado Federal en lo criminal y correlacional $n^{\circ} 2$ de San Martín. "Riveros, Santiago Omar y otros por la privación ilegal de la libertad, tormentos, homicídio e etc. ". 31-10-2005.
} 


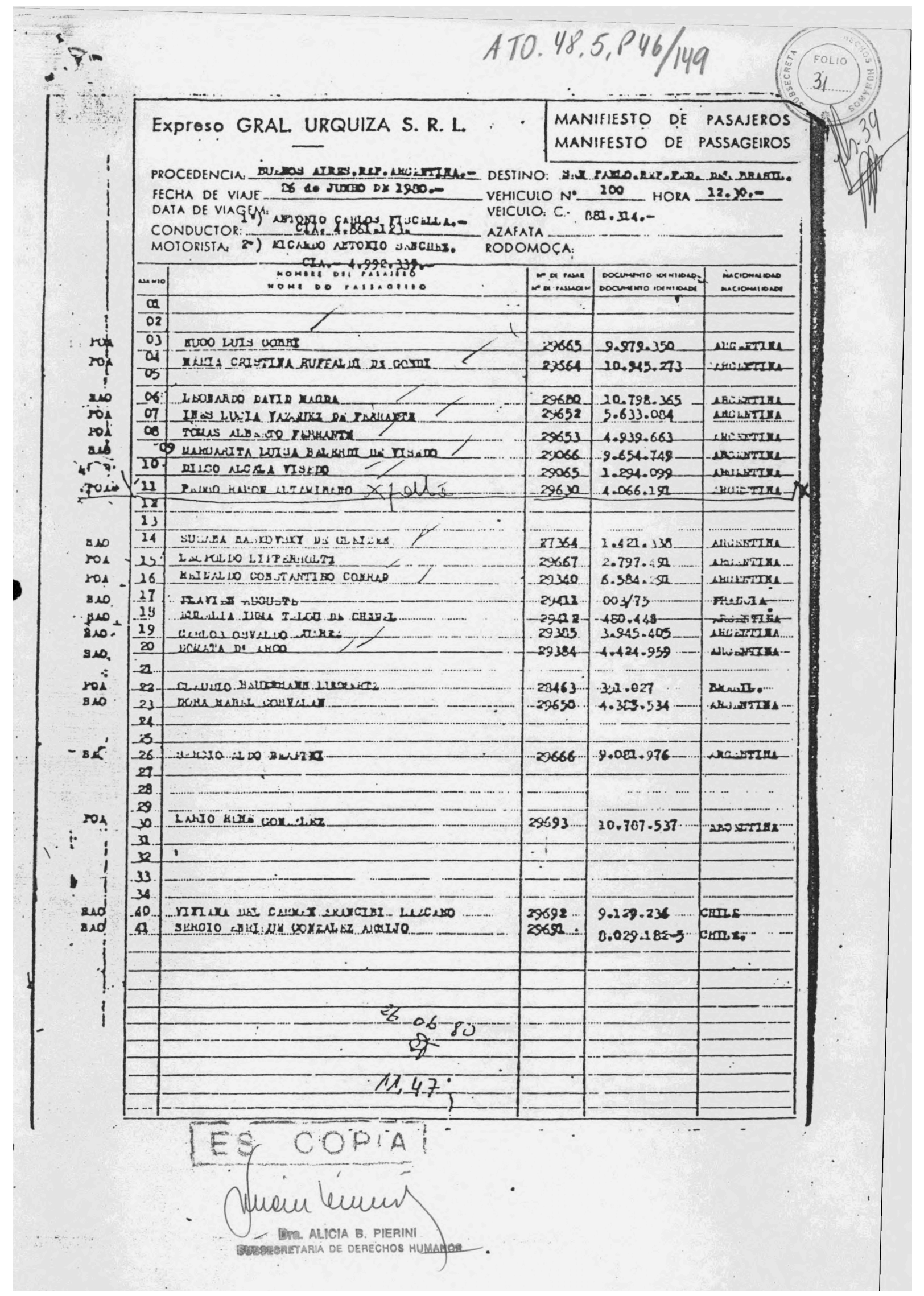

Figura 12 - Lista de passageiros do ônibus em que Jorge Oscar Adur viajava quando desapareceu. Fonte: Juzgado Federal de Paso de los Libres (2005). 
De posse desta lista o Juzgado solicitou diligências com intuito de tomar depoimentos dos passageiros do ônibus. Foram localizados e interrogados três passageiros da lista acima, número quantitativamente pequeno mas que produzem informações suficientes sobre o ocorrido. Essa lista está disponível no processo brasileiro acerca do desaparecimento de Adur, os depoimentos não. São inéditos, e trazem evidências que adicionadas às já conhecidas sobre o caso, demonstram sua veracidade. Três depoimentos diante de ocorrências repressivas é um número significativo, por não ser de fácil localização todos os passageiros. Considera-se que muitos passageiros poderiam ter usado documentos falsos assim como Adur, o que inviabiliza que sejam encontrados. Três pessoas que se dispõe a depor em um processo crime lesa humanidade, que não envolve um familiar, amigo ou conhecido é significativo.

Uma passageira disse ter feito muitas viagens de ônibus para o Brasil, e esta em específico já havia ocorrido há muito tempo, portanto não lembrava de nada de diferente que pudesse ter ocorrido. Os outros dois depoentes narram que lembram de uma viagem em 1980, e que por conta supostamente de drogas um homem teria ficado detido na fronteira. Nora Mabel Corvalan contou:

[...] cuando estaban en Paso de los Libres en la Provincia de Corrientes, el personal de aduana hizo descender del micro a todos los pasajeros para controlar los papeles y las valijas. En ese lugar permanecieron durante una hora aproximadamente a raíz de que revisaron todo el micro y además una persona quedó detenida alli porque aparentemente le habian secuestrado droga. ${ }^{375}$

Nora ainda relatou que chamou sua atenção o tempo que passaram na fronteira, que foi muito, mas como era sua primeira viagem nesse trajeto não sabia como se davam esses trâmites e demora. Ela, então, questionou um casal que estava no ônibus e esses lhe disseram que um homem havia sido preso por porte de drogas. Nora não viu quem era o homem que foi preso. $^{376}$

Já Leonardo David Magda lembrou que fez uma viagem para São Paulo com intuito de encontrar sua mãe. Conforme Leonardo, o ônibus da empresa Urquiza saiu do terminal do bairro de Once. Ele lembra que neste lugar um homem chamou a atenção dele "porque estaba vestido con un camperón de cuero [...] estaba con otro hombre más, que luego no subió al micro, con el cuchichiaba en la terminal y miraban raro, eran como misteriosos". Leonardo estava na poltrona 6 e diz que esse homem, da campera sentou depois dele. Adur estava na poltrona 11. O homem que chamou a atenção de Leonardo aparentemente viajava sozinho.

\footnotetext{
${ }^{375}$ ARGENTINA. Juzgado Federal en lo criminal y correlacional no 2 de San Martín. "Riveros, Santiago Omar y otros por la privación ilegal de la libertad, tormentos, homicídio e etc.". 31-10-2005. fl. 461.

${ }^{376}$ Ibidem, fl. 461.
} 
Quando chegaram em Paso de los Libres, a Gendarmeria entrou no ônibus como se estivesse buscando algo ou alguém - não era o procedimento aduaneiro embarcar no ônibus, principalmente a Gendarmeria - os agentes pediram que algumas pessoas desembarcassem. Leonardo diz que teve a impressão de que alguma denúncia tinha sido feita, pois não revistaram todos os passageiros, chamaram pontualmente poucas pessoas, ele estima que quatro. Enquanto estes passageiros tinham desembarcado os agentes revistaram o ônibus, e "sacaron un objeto del cenicero del pasajero de campera de cuero, no pudiendo ver el dicente que fue que sacaron de alli". ${ }^{377}$

Leonardo finaliza seu depoimento declarando que o homem da campera de couro ficou detido na fronteira, e os demais passageiros seguiram viagem normalmente, não viu briga ou ouviu gritos por conta da provável detenção do passageiro, e também alegou não ser capaz de descrever fisicamente este homem. ${ }^{378}$

Desse modo, dois testemunhos de pessoas que estavam na mesma lista de passageiros que o padre Adur destacam que um homem foi preso na fronteira, apesar de não recordar exatamente de todo o episódio. É muito provável que Adur seja o homem da campera, por toda a descrição, e principalmente pelos dados da passagem e a declaração de Leonardo que afirma este homem estar sentado alguns bancos após o dele, que era o número seis.

Segundo o relatório final da CNV,

\section{LOCAL DE DESAPARECIMENTO E MORTE}

Entre as cidades de Paso de los Libres e Uruguaiana, na fronteira entre a Argentina e o Brasil.

IDENTIFICAÇÃO DA AUTORIA

1. CADEIA DE COMANDO DO(S) ÓRGÃO(S) ENVOLVIDO(S) NA MORTE OU DESAPARECIMENTO

1.1 CENTRO DE INFORMAÇÕES DO EXÉRCITO (CIE)

Presidente da República do Brasil: general de Exército João Figueiredo Ministro do Exército: general de Exército Walter de Albuquerque Pires Chefe do CIE: general de Brigada Geraldo Araújo de Ferreira Braga Comandante do III Exército: general de Exército Antonio Bandeira

Chefe do Estado Maior do III Exército: general de Brigada Henrique Domingues 1.2 SERVIÇO NACIONAL DE INFORMAÇÕES (SNI)

Presidente da República do Brasil: general de Exército João Figueiredo Ministro do Exército: general de Exército Walter de Albuquerque Pires Chefe do SNI: general de Brigada Octávio Aguiar de Medeiros

Chefe da Agência do SNI em Porto Alegre: coronel Carlos Alberto Ponzi ${ }^{379}$

\footnotetext{
${ }^{377}$ ARGENTINA. Juzgado Federal en lo criminal y correlacional no 2 de San Martín. “Riveros, Santiago Omar y otros por la privación ilegal de la libertad, tormentos, homicídio e etc. ”. 31-10-2005. fl. 463.

378 Ibidem, fls. 463-464.

${ }^{379}$ BRASIL. Relatório Comissão Nacional da Verdade (CNV). Volume III Mortos e desaparecidos politicos. Brasília: Comissão Nacional da Verdade, 2014. p. 1960.
} 
O desaparecimento do padre Jorge Oscar Adur reverberou na imprensa, foi matéria de diversos jornais como no "Jornal do Brasil", que publicou a manchete: "Justiça e Paz procura padre argentino que sumiu no Sul"; de acordo com a matéria, o caso foi denunciado pelos montoneros e a Polícia Federal estava investigando, mas até aquele momento não havia registro de entrada ou saída do padre no Brasil. ${ }^{380}$

O Movimento Peronista Montonero publicou um panfleto de 10 páginas em seguida do desaparecimento do padre Jorge Oscar Adur, intitulado: "Padre Jorge Adur: Compromiso Cristiano por la liberación. Exigimos la aparición con vida del sacerdote Jorge Adur”. Consta de uma biografia da vida do padre Adur, onde nasceu, como se formou e então passa a comentar sobre a militância política e seus pressupostos políticos e cristãos. Contempla, também, uma carta escrita pelo então secretário geral dos montoneros Mário Firmenich ao episcopado argentino, em que descreve as propostas da condução nacional dos montoneros. $\mathrm{O}$ que se destaca neste panfleto é a descrição dos objetivos da viagem de Jorge Adur para a Argentina e depois ao Brasil:

\footnotetext{
Su misión en la Argentina

En su viaje a la Argentina, el Padre Jorge llevaba una misión que abarcaba tres tipos de tareas diferentes.

Tareas de solidaridad con familiares de presos y detenidos desaparecidos. Siempre fue para Jorge motivo de especial preocupación llevar su palabra de aliento a los que sufren las consecuencias de la represión, y en esta oportunidad volvió a reiterar su vocación solidaria aún a riesgo de su vida.

Tareas vinculadas a la actividad de los grupos cristianos argentinos con motivo de la visita del Santo Padre, Juan Pablo II a Brasil.

Hacer llegar a mano de los obispos integrantes del Episcopado Argentino la carta que, con fecha 29 de mayo de 1980, elevara el Movimiento Peronista Montonero a las máximas autoridades eclesiásticas argentinas. ${ }^{381}$
}

Tanto Lorenzo Ismael Viñas como padre Jorge Oscar Adur militavam no grupo montoneros. Claramente tinham objetivos diferentes: Lorenzo estava passando pelo Brasil em fuga, Adur estava em missão pelo projeto montonero. Assim como a contraofensiva fracassou, as viagens de Lorenzo e Adur também fracassaram.

Está presente que os casos de sequestro/desaparecimento de ambos não foi atividade de um só governo. As evidências de que colaborações repressivas ocorriam nesta fronteira estão mais que demonstradas - tanto do ponto de normativo, como de modo secreto. Lorenzo

\footnotetext{
${ }^{380}$ Jornal do Brasil. Justiça e Paz procura padre Argentino que sumiu no Sul. 6 de agosto de 1980.

${ }^{381}$ Movimento Peronista Montonero. Padre Jorge Adur: compromiso Cristiano po la liberación. Exigimos la aparición con vida del sacerdote Jorge Adur. Argentina, 1980. p.7.
} 
e Adur viajavam na poltrana 11; segundo Mariano ${ }^{382}$, é possível que esse número de poltrona fosse o escolhido para os suspeitos que viajavam com direção ao Brasil, visto que o sistema de "marcadores" atuava em diferentes cidades e locais.

A Comissão Nacional da Verdade analisou estes dois casos. Lembrando que a Comissão Especial Sobre Mortos e Desaparecidos Políticos já havia analisado estes casos e o Estado brasileiro assumiu a responsabilidade no sequestro e desaparecimento de ambos, inclusive indenizando as famílias.

Para a CNV, padre Jorge Oscar Adur foi um caso no âmbito da Operação Condor; já o de Lorenzo Ismael Viñas foi um caso no contexto de sistemáticas violações de direitos humanos. De acordo com a resolução sobre o caso de Lorenzo Ismael Viñas:

\begin{abstract}
Diante das investigações realizadas, conclui-se que Lorenzo Viñas desapareceu em 26 de junho de 1980 na fronteira entre Brasil e Argentina, em contexto de sistemáticas violações de direitos humanos. Recomenda-se a continuidade da cooperação entre Brasil e Argentina para o esclarecimento da prisão ilegal e do desaparecimento de Lorenzo Viñas, assim como a continuidade das investigações sobre as circunstâncias do caso, para a identificação e responsabilização dos demais agentes envolvidos. $^{383}$ [grifo da autora]
\end{abstract}

Já a resolução relativa ao padre Jorge Oscar Adur afirma que:

Diante das investigações realizadas, conclui-se que Jorge Oscar Adur desapareceu no dia 26 de junho de 1980, entre as cidades de Paso de los Libres e Uruguaiana, região fronteiriça Argentina- Brasil, no marco da coordenação repressiva empreendida por autoridades brasileiras e argentinas, denominada Operação Condor. Recomenda-se a retificação da certidão de óbito de Jorge Oscar Adur, assim como a continuidade das investigações sobre as circunstâncias do caso, para a localização de seus restos mortais e a identificação e responsabilização dos agentes envolvidos. $^{384}$ [grifo da autora]

Não há, no relatório da CNV, justificativa para essa resolução diferente entre ambos os casos. Para além de questionar o trabalho da comissão, ressalta-se que o local onde ocorreram os sequestros/desaparecimentos estava preparado para operações repressivas conjuntas. Ambos se deram no mesmo contexto, com as mesmas conexões repressivas que utilizavam a mesma estrutura logísitica. Tanto Lorenzo quanto Jorge Adur tinham perfil de pessoas consideradas "perigosas", portanto, independente das conclusões finais da comissão, esta Tese

\footnotetext{
${ }^{382}$ MARIANO, S. Nilson. Montoneros no Brasil - Terrorismo de Estado no seqüestro-desaparecimento de seis guerrilheiros argentinos. Porto Alegre: PUCRS, 2006. Dissertação, Mestrado em História - PUCRS. Porto Alegre, p. 78.

${ }^{383}$ BRASIL. Relatório Comissão Nacional da Verdade (CNV). Volume III Mortos e desaparecidos politicos. Brasília: Comissão Nacional da Verdade, 2014. p. 1958.

${ }^{384}$ Ibidem, p. 1961.
} 
advoga que ambos foram casos incutidos nas atividades de terrorismo de Estado e conexões repressivas do Brasil e Argentina, e contemplam características que os colocam no marco da Operação Condor.

\subsection{Margarita e Cristina: sequestro binacional}

Um dos casos mais curiosos ocorridos em Uruguaiana foi a tentativa de sequestro de Margarita Mengol Villas de Moroz e o efetivo de Cristina Gloria Fiori, ocorrido em novembro de 1979. Policiais civis gaúchos colaboraram com militares argentinos, na tentativa de sequestrar as duas mulheres em Uruguaiana. Margarita é cidadã espanhola, e Cristina é nascida na Argentina.

Conforme o relatório do Departamento de Polícia Federal, no dia 17 de novembro de 1979, Cristina foi detida ilegalmente por dois policiais brasileiros e um argentino ${ }^{385}$. Margarita foi para a Espanha e a argentina desapareceu. O delegado de Polícia Federal em Uruguaiana, José Antonio Hahn, afirma que: "Eu havia promovido à responsabilização criminal de dois policiais estaduais que haviam tido ainda a ousadia de realizar um sequestro em território brasileiro para entregar o sequestrado aos argentinos" ${ }^{386}$ Os arquivos do Serviço Nacional de Informações compreendem quatro relatórios sobre o caso. Segundo esses documentos, o que ocorreu foi um sequestro binacional, com colaboração entre agentes de instituições de segurança do Brasil e Argentina.

No dia 17 de novembro de 1979, dois policias civis brasileiros e um argentino, utilizaram um veículo da Delegacia de Polícia local, para procurar duas mulheres, supostamente argentinas, que estavam hospedadas em um hotel no centro de Uruguaiana, o Hotel Palace. Uma destas mulheres foi presa no local e a outra fugiu. ${ }^{387}$

Em 23 de novembro, seis dias após a realização desta ação conjunta, quatro policias federais de Uruguaiana, solicitaram permissão, ao policial responsável pela Aduana, para capturar e levar as duas mulheres para a Argentina. Junto estava um policial argentino que "descuidadamente, disse que uma das procuradas já se encontrava presa em seu país". ${ }^{388}$ Quatro dias depois, agentes da Polícia Federal prenderam uma dessas mulheres que estava

\footnotetext{
385 Serviço Público Federal. Mininistério da Justiça. Departamento de Polícia Federal - Divisão de Polícia Federal em Uruguaiana/RS. 28 de novembro de 1979.

386 Ministério Público Federal. Procuradoria da República no Rio Grande do Sul. PRM-URU-RS00011734/2011. fl. 211.

387 BRASIL. Serviço Nacional de Informações. AC_ACE_5367_80. Atuação da polícia Argentina em território brasileiro - Uruguaiana/RS. 08 de dezembro de 1979.

${ }^{388}$ Ibidem.
} 
escondida em uma casa, e foi transferida para Porto Alegre. O delegado da Polícia Federal confirmou que ocorreu uma operação conjunta, entre policiais brasileiros e argentinos, em Uruguaiana em 17 de novembro de $1979 .{ }^{389}$

Este é um dos primeiros documentos que foram liberados sobre o caso, em que todos os nomes estavam tarjados, e com informações desencontradas. Após a Lei de Acesso à Informação, os nomes que eram tarjados nos documentos do Arquivo Nacional foram divulgados. Assim, verifica-se que as cidadãs procuradas pela polícia Argentina eram Margarita Mengol Villas de Moroz e Cristina Gloria Fiori de Vivo. O dono do Hotel Palace era Vivaldino Dornelles da Costa.

Os argentinos, que seriam casados com as duas procuradas, chamam-se: Oscar Alfredo Mendes e Juan Gualberto Gamarra. Esse caso teve repercussão na mídia na época, e a Polícia Federal interrogou os envolvidos no caso. Porém esses depoimentos só foram liberados recentemente para consulta no Arquivo Nacional.

No mesmo relatório, há informação de que houve duas tentativas normativas, para que essa ação fosse executada. Há um informe do dia 14 de novembro de 1979, afirmando que pela segunda vez o pedido de permissão para buscas de ambas cidadãs tinha sido negado. Nesta data dois argentinos, ditos funcionários da Gendarmeria, pediram para falar com o supervisor do serviço de migração, queriam informações sobre "as argentinas Margarita Moroz e Cristina de Vino, procuradas na Argentina por furtos e outros delitos. Foram informados que deveriam proceder por vias legais, ao que responderam que não estavam querendo agir ilegalmente, mas apenas informar sobre a estada delas no Brasil." ${ }^{\text {390 }}$

Conforme o proprietário do Hotel Palace, localizado no centro da cidade de Uruguaiana, os quatro se hospedaram no dia $1^{\circ}$ de novembro de 1979 como dois casais: Oscar e Margarita, Juan e Cristina. Somente os documentos dos homens foram utilizados para registro no hotel. No dia 17 de novembro, dois policiais civis brasileiros e um policial com uniforme azul e amarelo foram até o hotel no começo da tarde, procurando por duas argentinas.

Vivaldino, o dono do Hotel, afirmou que haviam duas estrangeiras hospedadas em seu hotel, mas que não tinha documentos delas. Oscar Mendes, que estava perto, ouviu a conversa e foi conversar com os policiais, declarou não ser casado com Margarita, mas que tinha feito o registro assim por ser mais fácil a hospedagem. Os policiais confirmaram que se tratavam das

\footnotetext{
389 BRASIL. Serviço Nacional de Informações. AC_ACE_5367_80. Atuação da polícia Argentina em território brasileiro - Uruguaiana/RS. 08 de dezembro de 1979.

${ }^{390}$ BRASIL. Serviço Nacional de Informações. APA_ACE_878_79. fl. 12.
} 
mulheres que eles estavam procurando e foram procurá-las nos quartos. Margarita não se encontrava no hotel, e os policiais levaram os documentos e pertences dela; Cristina estava no banho e foi levada pelos agentes brasileiros e o argentino. $\mathrm{O}$ dono do hotel contou que sua filha, um funcionário e um hóspede foram testemunhas do caso. ${ }^{391}$

Oscar e Juan também prestaram depoimento. O relato dos dois é parecido; segundo eles, conheceram as moças na cidade, e começaram relacionamento amoroso. Os dois viviam em uma pensão em Uruguaiana. Pediram para que pudessem viver com Margarita e Cristina na pensão, mas não foi permitido, então hospedaram-se no Hotel Palace no começo de novembro e não sabiam detalhes da vida pregressa das duas.

A Polícia Federal não perguntou que atividades as mulheres exerciam na cidade e eles não comentaram sobre isso. Sobre o dia 17 de novembro, Oscar disse que estava com Juan e Margarita em frente ao hotel quando viu o carro da Polícia Civil estacionando e três pessoas que estavam no carro se dirigiram ao hotel. Ele entrou para saber do que se tratava, e enquanto isso Juan e Margarita "se ausentaram". Foi informado pelos policiais que as duas eram procuradas por crime de furto na Argentina. Ele acompanhou os policiais até seu quarto e de Juan, e afirma que depois disso só encontrou Juan e Margarita após uma semana. ${ }^{392}$

Juan difere em um aspecto do depoimento de Oscar; segundo esse depoimento, quando Oscar percebeu os policiais chegando no hotel, "fez um sinal" indicando que ele saísse com Margarita, o que Juan fez. Daí em diante, Juan conta sobre a semana que passou com Margarita, em que eles se hospedaram em uma pensão em Uruguaiana. Ao encontrar com Oscar, foi informado que Cristina estava presa na Argentina. Margarita saiu da pensão acompanhada por Oscar e Juan foi para Paso de los Libres. ${ }^{393}$

Margarita foi presa na casa de um casal argentino, conhecidos dela, após ter se encontrado com Oscar. Ao que consta nos documentos sobre sua prisão, a Polícia Federal chegou na casa onde ela estava junto com seu companheiro, e segundo Oscar foi a última vez que ele a viu. ${ }^{394}$

A revista Veja publicou reportagem sobre o caso, sob o título: "Sequestro: Basta querer, em 24 horas o delegado apurou tudo”, em clara referência ao sequestro dos uruguaios ocorrido um ano antes em Porto Alegre ${ }^{395}$. A matéria começa traçando um paralelo entre os dois casos de prisão ilegal de estrangeiros no Rio Grande do Sul. Conforme a revista: o

\footnotetext{
${ }^{391}$ BRASIL. Serviço Nacional de Informações. APA_ACE_878_79. Atuação da polícia Argentina em território brasileiro - Uruguaiana/RS. 28 de novembro de 1979 . fls. 10.

392 Ibidem, fl. 16.

${ }^{393}$ Idem, fl. 20.

${ }^{394}$ Idem, fl. 22.

395 Já tratado nesta Tese no segundo capítulo, item 2.3.
} 
delegado José Antônio Hahn recebeu um telegrama da Interpol que pedia a prisão de Cristina e Margarita, em quatro dias de investigação Margarita foi localizada, e então a PF foi informada do sequestro de Cristina. Em uma nota oficial Hahn admitiu a possibilidade de uma ação ilegal. Ao mesmo tempo o superintende de Serviços Policiais Luis Carlos Carvalho da Rocha "expediu a informação definitiva: os agentes Rocha e Peixe tinham participado do sequestro e em consequência disso já estavam afastados de suas funções. Ao mesmo tempo, abriu-se um inquérito policial no qual os dois agentes foram indiciados por "exercício arbitrário ou abuso do poder". 396

O "Jornal do Brasil" publicou, no final de dezembro, reportagem intitulada: "Resgate da Argentina: Ex-amante de militar iria morrer em 79". A matéria levanta hipótese de que Margarita e Cristina haviam tido relacionamento amoroso com agentes da repressão argentinos; logo, sabiam muito sobre essas atividades, motivo pelo qual foram vítimas dessa operação binacional. O jornal cita uma suposta conversa - já que não há, na reportagem, qual fonte teria declarado - entre o delegado Hahn e o comandante do Regimento da Brigada de Cavalaria de Alegrete:

[...] general Evaraldo Reis, o chamou [o delegado Hahn] ao quartel e lhe disse: "Delegado, o senhor fez o que tinha de fazer. Mas, agora, como é que fica se tivermos que, no futuro, fazer operações veladas? Hahn desconversou, alegando desconhecer o que eram operações veladas". ${ }^{397}$

Ambas publicações destacam o papel do delegado Hahn, mas não adensam sobre o desaparecimento de Cristina. O "Jornal do Brasil" apresenta a hipótese de sequestro por um suposto relacionamento com repressores, mas não passa de uma frase sobre isso. A matéria foi publicada 12 anos após o sequestro, e não cita fonte alguma sobre as suposições.

Os dois policiais brasileiros envolvidos foram Antonio Carlos Rocha e Hélio Alves Peixe. O policial argentino foi identificado apenas como Sub-Comissário "Mazi”. Em 2009, a Polícia Federal em Uruguaiana convocou Rocha e Peixe para depor ${ }^{398}$, por conta de um pedido de abertura de inquérito pelo Procurador da República Ivan Cláudio Marx. Esse

\footnotetext{
${ }^{396}$ Sequestro: Basta querer, em 24 horas o Delegado apurou tudo. Revista Veja, 5 de dezembro de 1979. p. 33. Acervo Museu de Comunicação Social Hipólito José da Costa.

${ }^{397}$ Resgate da Argentina. Ex-amante de militar iria morrer em 79. Jornal do Brasil. 29 de dezembro de 1991. p. 8. Acervo do Movimento Justiça e Direitos Humanos.

398 Esses depoimentos não estão disponíveis para consulta em nenhum acervo, a autora desta Tese teve acesso aos autos do processo, via Procuradoria da República.
} 
inquérito investigava as ocorrências repressivas em Uruguaiana após a promulgação da Lei de Anistia (de 28 de agosto de 1979). ${ }^{399}$

Antonio Carlos Rocha comentou sobre o sequestro de Cristina; ele afirma ter apenas localizado as argentinas, atendendo a um pedido da Polícia Federal daquele país. Seu papel teria sido somente de alertar as autoridades argentinas. Foi condenado e demitido da Polícia Civil, mas posteriormente absolvido e reintegrado ao efetivo policial, e transferido antes de 1980. Os dois policias responderam a denúncia do Ministério Público por abuso de autoridade; condenados, eles recorreram e foram absolvidos. Ao afirmar que seu papel foi o de alertar as autoridades argentinas, fica compravada a troca de informações entre os agentes de segurançaa pública de ambos os países. Peixe disse que não declararia nada, pois o que tinha de falar já havia sido dito no processo que ele respondeu à época do ocorrido, e que foi absolvido. $^{400}$

Fernandez, em sua tese de doutorado, analisou o caso de Margarita e Cristina. Ele intitula o item como: "A banalização do Condor: o estranho caso de Cristina Fiori de Vina". Para esse pesquisador essa ação pode ter sido uma ajuda entre colegas, ambos agentes da repressão, e que estavam convencidos que suas atividades estariam amparadas pelo aparato estatal que vingava no período. Fernandez advoga que foi uma operação ilegal, e que seguiu a metodologia da Operação Condor, mas alerta que não há comprovação de que houve ordem de superiores para a execução do sequestro. ${ }^{401}$

Ainda segundo as considerações deste pesquisador, caso não tenha sido uma atividade da Operação Condor, foi a banalização desta, [...]uma aberrante ação criminosa, agora despojada da justificativa ideológica que lhe dava sustentáculo moral entre seus defensores e adeptos. Uma reverberação de atividades que eram corriqueiras na Argentina, onde agentes da repressão usavam o aparato estatal para fins pessoais, como matar desafetos ou roubar. ${ }^{402}$

Nessa Tese a hipótese de que houve uma "banalização" das atividades do Plano Condor, defendida por Fernandez, não é totalmente descartada; porém, não se sabe se houve uma ordem superior ou não, já que casos como o de Lorenzo Ismael Viñas e Jorge Oscar Adur não há registro de uma ordem - explícita - de algum superior.

\footnotetext{
399 Ministério Público Federal. Procuradoria da República no Rio Grande do Sul. PRM-URU-RS00011734/2011. fl. 179.

${ }^{400}$ Ibid. fl. 172.

${ }^{401}$ FERNANDEZ, Jorge C. Anclaos en Brasil: a presença argentina no Rio Grande do Sul (1966-1989). Porto Alegre: UFRGS, 2011 Tese (Doutorado em História) - Programa de Pós-Graduação em História da UFRGS. Universidade Federal do Rio Grande do Sul, Porto Alegre, 2011. p. 363.

${ }^{402}$ Ibidem, p. 363.
} 
Cristina desapareceu aos 33 anos em uma operação cooperativa entre agentes de instituições públicas de segurança, sob custódia da Polícia Civil gaúcha, a qual prendeu-a no Hotel Palace. Junto com os policiais civis estava um agente de segurança argentino. Caso tenha sido, de fato, uma "banalização" do Condor, tal condição não faz com que esse episódio seja desconsiderado do plano de ação de tal cooperação, bem como é importante para compreender a repressão na fronteira Uruguaiana-Paso de los Libres no final da década de 1970.

Margarita vive na Espanha e, em 2013, deu entrevista para o jornal "Zero Hora”. Nessa reportagem, ela conta uma versão para os acontecimentos de 1979. Foi salva com ajuda do delegado Hahn, que investigou o caso, e do cônsul espanhol em Porto Alegre, que forneceu os documentos e a viagem para a Espanha.

Margarita disse na entrevista que tem muitos segredos para revelar sobre o caso, porém não avançou nas informações já conhecidas pelos documentos existentes sobre esse fato. Quando fugiu para a Espanha, ela deixou na Argentina os pais, o marido e dois filhos. Margarita contou que foi para Uruguaiana para fugir de acusações na Argentina, das quais seria inocente, ela não diz que acusações são estas. Era casada com um policial que foi preso acusado de matar o filho de um militar. Seu marido aconselhou-a fugir, pois corria o risco de ser presa também. Ela alega ter conhecido Cristina na viagem até Uruguaiana, e que descobriram o paradeiro delas após uma ligação que ela fez para seu filho, o qual era monitorado sem que ela soubesse.

Margarita diz, sobre o paradeiro de Cristina: "Jamais soube o que aconteceu depois que os policiais da Argentina e do Brasil a tiraram do hotel à força, levando dinheiro, joias e minha documentação, jamais recuperada". Ela comenta que o custo de ter salvado sua vida foi seus filhos, que ficaram na Argentina, crescerem acreditando que ela os tinha abandonado, pois só pode se reencontrar com sua família depois de 20 anos. ${ }^{403}$ Apenas o fato dela ter declarado onde conheceu Cristina é "novidade" no caso. Vale ressaltar que ela não comenta sobre esse episódio - essa entrevista é uma rara exceção.

403 Sobrevivente de ação clandestina da Operação Condor conta detalhes sobre sequestro de argentina em Uruguaiana. Jornal Zero Hora, 25 de maio de 2013. Disponível em: http://zh.clicrbs.com.br/rs/noticias/noticia/2013/05/sobrevivente-de-acao-clandestina-da-operacao-condorconta-detalhes-sobre-sequestro-de-argentina-em-uruguaiana-4148644.html 


\section{CONCLUSÕES}

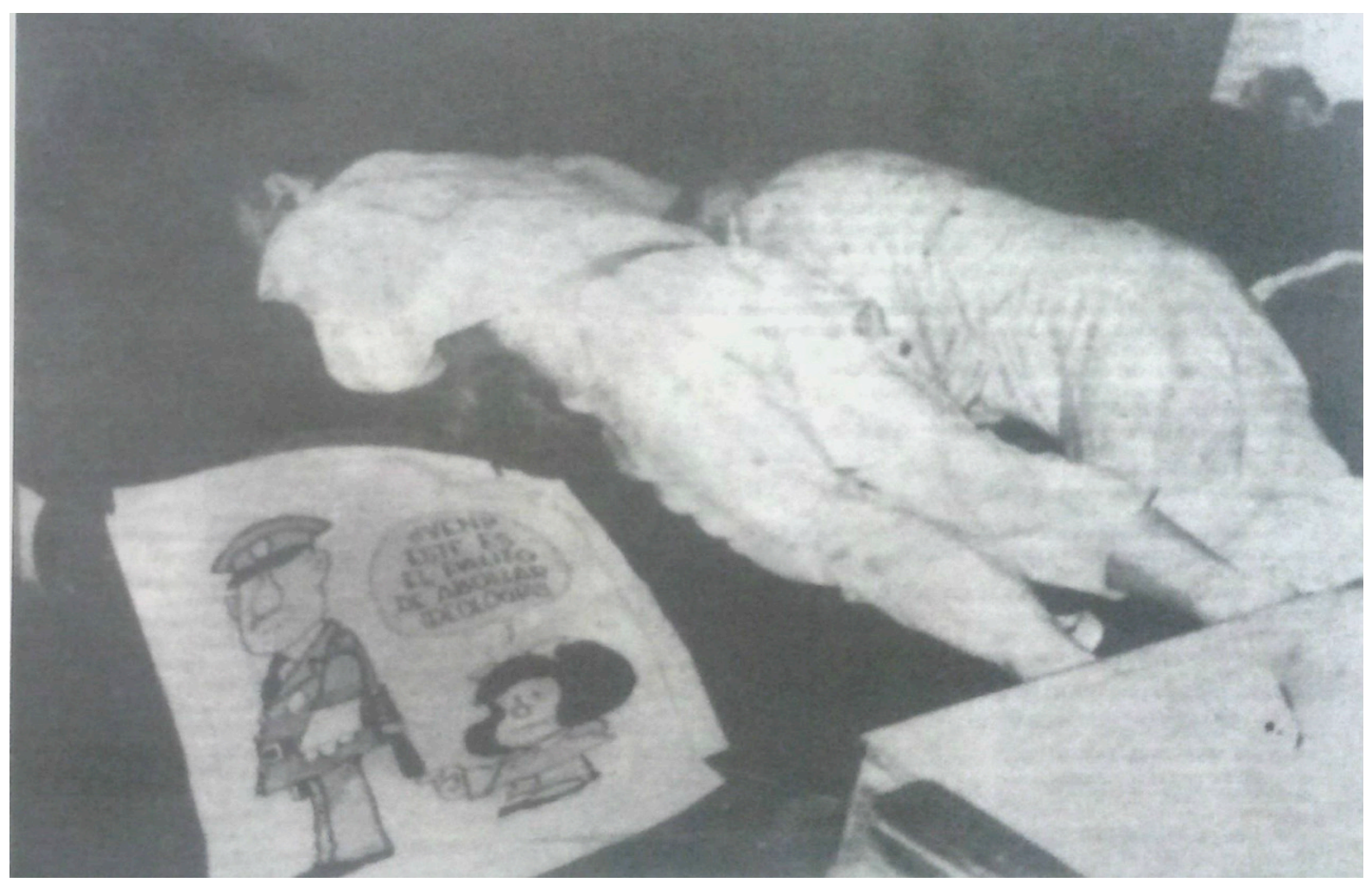

Figura 13 - Foto publicada no Diário Página 12.

Fonte: Garulli, Charlier e Caraballo (2011, p. 91).

"É importante colocar as imagens em relação, pois elas não falam de forma isolada" ${ }^{404}$ A associação imagética apresentada acima fora montada pela repressão argentina, e cobria os corpos de suas vítimas fuziladas com um pôster da charge do Quino, no famigerado caso "La noche de los palotinos". Três padres e dois seminaristas, pertencentes à comunidade Palotina, foram assassinados na madrugada de 4 de julho de 1976. Os religiosos foram mortos dentro da Paróquia de San Patrício, localizada no bairro de Belgrano, na cidade de Buenos Aires, e as primeiras pessoas que adentraram a igreja, na manhã seguinte, se depararam com os corpos - nas paredes e tapetes, as inscrições que diziam: "Esto les pasa por envenenar la mente de la juventud ${ }^{\prime 405}$.

A epígrafe desta Tese é parte dessa inscrição, emblemática para demonstrar o apagamento da democracia argentina. Fazer essa montagem entre epígrafe e conclusão, entre dibujo e apropriação deste, com intuito de retratar a repressão, é entender por meio de

${ }^{404}$ DIDI-HUBERMAN, Georges. Georges Didi-Huberman: “yo no se lo que es arte”. Entrevista realizada por Cecília Macón. La Nación, ADN Cultura, 31 de outubro de 2014. p. 08. Tradução da autora desta Tese.

405 CONADEP. Nunca Más: el caso de los Padres Palotinos. Disponível em: http://www.desaparecidos.org/arg/conadep/nuncamas/356.html 
imagens o terror de Estado implantado pela Ditadura de Segurança Nacional na argentina, e que esteve presente também no Brasil, Chile, Uruguai, Paraguai e Bolívia, os participantes da Operação Condor.

Esta Tese analisou as atividades do Terrorismo de Estado praticado nas Ditaduras de Segurança Nacional do Cone Sul em um espaço delimitado: a fronteira Uruguaiana-Paso de los Libres. A Tese demonstrou o caráter da cooperação repressiva nessa fronteira no final dos anos 1970 e como esta foi uma região emblemática na repressão do Cone Sul, no último ciclo de suas ditaduras. A fronteira, aqui, é uma zona de contato e tensão, uma "fronteira manejada" conforme as especificidades políticas.

Desta forma, a construção da Tese se deu, no primeiro momento, demonstrando que as mais recentes ditaduras do Cone Sul foram baseadas na Doutrina de Segurança Nacional e na prática do terrorismo de Estado. Estes dois conceitos são essenciais para se entender a diferença entre os acontecimentos, do golpe contra a democracia dos anos 1970 e os ocorridos anteriormente na região.

Os movimentos antidemocráticos dos mais recentes governos ditatoriais do Cone Sul basearam-se sobre dois pilares, um "teórico" e outro instrumental: a Doutrina de Segurança Nacional e o terror de Estado. A existência de um "inimigo interno", defendido e difundido por essa Doutrina, é um diferencial importante, pois colocava os cidadãos também como responsáveis pela manutenção da "ordem estatal", ao mesmo tempo em que alguns eram “culpados" por dela discordarem. Ao incutir essa ideia, com inspiração na DSN, na sociedade, ganharam apoio de parcelas socias, para o segundo passo: golpe contra a democracia.

Uma estrutura repressiva foi montada com base em organizações já existentes e novos modos de atuação. Mecanismos de informações aprimorados, pactos entre instituições de segurança e as prisões clandestinas foram novas formas de agir das ditaduras dos anos 1970.

Os sequestros, prisões, torturas e principalmente os desaparecimentos/mortes impõe o terror em diversos setores da sociedade. Ao mesmo tempo em que tentaram "calar" quem atuava contra as ditaduras, não permitiam que demais parcelas sociais soubessem de suas atividades repressivas ocultas. As ações subterrâneas de violência não chegavam ao grande público, mas os parceiros de ação contra as ditaduras "sabiam" o que ocorria, por meio do desaparecimento/morte de pessoas de suas relações. Nem todos os casos de tortura, morte, desaparecimento, enfim, dos crimes cometidos pelos governos dos anos 1970 no Cone Sul foram ocultos. Muitos foram publicizados; em geral a justificativa era de tratar-se de um caso pontual. Ou seja, não seria o modus operandi, apenas uma ação isolada de agentes estatais. 
Essas duas faces, normativa e discricionária, instituíram-se em amálgama com a Doutrina de Segurança Nacional, o terrorismo de Estado com intuito de fortalecer e manter o governo ditatorial através do medo e do terror, voltado principalmente aos "inimigos", além de outras formas de controle social, como a censura. Diferentes em suas implantações, Brasil, Chile e Argentina utilizaram estes pilares para gerir suas mais recentes ditaduras. $\mathrm{O}$ terrorismo de Estado foi difundido entre os países da região, com intuito de fortalecer as atividades repressivas em âmbito regional. E, dentre estas, a implementação de estrutura que atendeu às ações da Operação Condor no Rio Grande do Sul. A Tese demonstra como o território gaúcho foi essencial para o aparato repressivo, e como sua complexa organização institucional funcionou na fronteira de Uruguaiana e Paso de los Libres.

Acerca da fronteira estudada na Tese, tratou-se da construção da Ponte Internacional, a qual mudou significativamente o cotidiano dos habitantes dos dois lados da fronteira, tornando-se espaço, simultaneamente, de esperança para os que tentavam fugir da ditadura argentina e de cooperação repressiva da Operação Condor. Foi essa ponte que facilitou o "cruze de fronteira", ao mesmo tempo em que foram instaladas diversas instituições de controle aduaneiro. Reconstruir esse processo, o antes e depois da ponte, possibilitou compreender a região, contextualizar e debater o modus operandi da repressão que ali foi perpetrada no final dos anos 1970.

A fronteira Uruguaiana-Paso de los Libres é uma "fronteira manejada", pois se ajusta conforme as especificidades. Nela, ao mesmo tempo em que há integração, há tensionamento. Nos anos 1970, a fronteira era, também, ideológica. Ou seja, ao mesmo tempo em que agentes estatais atuavam para garantir a segurança de seu território e cidadãos, agiam em conjunto com os agentes "vizinhos" contra as pessoas que deveriam proteger. O caráter mais relevante da repressão é transnacional, pois não se guiará pela nacionalidade da vítima, mas pela cooperação interestatal estabelecida pela Operação Condor - que, com outras características, já existia anteriormente na região.

Esta Tese tornou possível demonstrar e entender como esteve "manejada" de modo normativo a estrutura de coerção e repressão construída em Uruguaiana e Paso de los Libres. Estas atividades, apresentadas como normativas. Ou seja, atividades que não foram silenciadas e/ou apagadas, as que estão documentadas e, em um grau mais acessível aos pesquisadores, bem como não eram ocultas da sociedade. 
A Tese apresentou casos de repressão ocorridos na fronteira Uruguaiana-Paso de los Libres no contexto da Operação Condor na região. Foi o caso de Jacques Souza Coimbra, que não fora analisado por outro trabalho acadêmico e está aqui demonstrado com documentação do Ministério das Relações Exteriores, Arquivo Nacional e Arquivo Público Mineiro. As atividades do cônsul Ney Corrêa em Uruguaiana, também tratadas pela primeira vez, ajudaram a compreender como estava estruturada essa fronteira em termos de trânsito de pessoas, fugas, prisões e conexões repressivas normativas.

A Tese também demonstrou a existência de casos ocultos, os discricionários, de como a repressão subterrânea funcionou, quem nela atuou e quais foram os grupos políticos mais visados por ela. Foi demonstrado que em Paso de los Libres foi instalado um centro de detenção clandestino, a fazenda La Polaca, emprestada ao Exército argentino, que serviu para interrogar - nisso entende-se tortura física e psicológica - pessoas sequestradas na aduana. Instalar uma prisão clandestina em Paso de los Libres revela a importância deste "passo de fronteira" para o sistema repressivo argentino, e do Cone Sul. La Polaca, além de servir para os interrogatórios, também foi um local de trânsito, onde os presos aguardavam até ser encaminhados para outras prisões, também clandestinas, em outros pontos da Argentina.

Ao comprovar a existência desta prisão, e que no Rio Grande do Sul também havia centros repressivos com o mesmo caráter, fica demonstrado ter havido na fronteira Uruguaiana-Paso de los Libres um elo da vasta cadeia repressiva da Operação Condor. Com base nas ocorrências analisadas, a fronteira nesse contexto esteve manejada no âmbito normativo na margem brasileira, já que as ocorrências desse modo foram mais intensas em Uruguaiana, ao passo que em Paso de los Libres as atividades ocultas eram praticadas com mais intensidade. Operavam juntos, em colaboração, com protagonismo argentino nos casos ocultos, e brasileiro, nos normativos.

A região de fronteira não é uma região de equilíbrio entre os lados argentino e brasileiro, quer na vida cotidiana, quer na repressão política. Assim, no período em tela, a Argentina mantinha uma repressão ativa que, embora secreta, era de conhecimento dos ativistas políticos. Já em Uruguaiana, devido a serem diferentes as circunstâncias políticas do Brasil (vide abertura), a repressão era mais discreta, o que dava um ar de normalidade que não correspondia à realidade. Como se demonstrou nesta Tese, nos anos da Operação Condor não havia segurança de integridade física e liberdade individual ao se cruzar a ponte para aqueles considerados inimigos políticos pelos regimes militares argentino e brasileiro. 
Esta Tese teve como corte temporal o final dos anos 1970, quando os principais perseguidos na região em estudo eram militantes Montoneros, grupo guerrilheiro argentino. Esse grupo tornou-se prioridade para a repressão argentina por dois motivos: foi o único grupo que ainda resistia, com certa organização; e pela ocorrência da contraofensiva montonera, última e frustrada acão, de tentar derrubar o governo ditatorial. A resposta dos militares argentinos ao desafio montonero foi o Operativo Murciélago, atividade de caráter transnacional, alcançando especialmente o Brasil e o México nas Américas e, na Europa, a França e a Espanha. Os chamados "agentes morcegos", grandes especialistas em perseguição e tortura, atuaram em Paso de los Libres, tanto na aduana argentina, instalada em uma das extremidades da ponte sobre o rio Uruguai, como na fazenda La Polaca.

Os depoimentos de Silvia Noemy Tolchinsky e Júlio Héctor Símon, e as narrativas acerca da presença de ambos em Paso de los Libres, comprovam que "marcadores" atuaram na aduana. Por meio do estudo da atuação desses dois agentes, visualiza-se o cotidiano de coerção fronteiriço. Silvia garantiu ter visto e conversado com Lorenzo Ismael Viñas em seu depoimento para a CONADEP, que serviu de prova para os processos judiciais de reparação no Brasil e na Argentina, e para o processo que criminaliza militares e civis que atuaram no âmbito da Operação Condor, que tramita em Buenos Aires. Já “Turco Julián”, agente morcego e um dos mais emblemáticos torturadores da Argentina, confessou ter atuado em Paso de los Libres. Ele manteve estreita relação com Uruguaiana, onde se tornou figura "folclórica" devido à sua vestimenta - um chapéu e casaco, ambos pretos, mesmo no verão e seu suposto envolvimento com uma conhecida prostituta da cidade. Após o fim da ditadura na Argentina, "Turco Julián” permaneceu algum tempo em Uruguaiana, até voltar a seu país, onde foi preso por graves violações aos direitos humanos.

Jorge Oscar Adur e Lorenzo Ismael Viñas foram vítimas de conexões repressivas impostas no âmbito da Operação Condor. Pelas evidências documentais e pelas características de ambos os casos - local da ocorrência, aparato utilizado pelos repressores e circunstância simultânea com o funcionamento do Operativo Murciélago -, eles foram vítimas de ações da Operação Condor. Casos já admitidos na Argentina como parte desta verdadeira internacional da repressão, por meio do processo judicial que investigou as atividades praticadas no âmbito do Plano Condor. Do mesmo modo, que o caso de Lorenzo Isamel Viñas faz parte do processo acerca dessa mesma sociedade entre ditaduras que está tramitando em Roma. 
O caso de Margarita Mengol Villas de Moroz e Cristina Gloria Fiori, em novembro de 1979, provavelmente também foi uma ocorrência do Plano Condor, uma "banalização" talvez, como apontado na tese de Jorge Fernandez, intitulada "Anclaos en Brasil: a presença argentina no Rio Grande do Sul (1966-1989)"; ainda assim, foi uma operação com todas as características de repressão utilizadas no âmbito dessa rede, uma vez que os agentes argentinos e brasileiros utilizaram a estrutura e a formalização deste pacto de terror para sequestrar ambas. Nesse ponto, considera-se que ambas, até o momento, não militavam contra o regime, e isso poderia atestar que não foi um caso do Plano Condor, porém quando se utiliza essa estrutura para fins, que sejam, pessoais, ela está imbricada nestas atividades.

Conforme analisado nesta pesquisa, é importante salientar que a estrutura repressiva de Uruguaiana e Paso de los Libres não foi um produto da Operação Condor. Como comprovado nesta Tese, já existia repressão e troca de informações entre as instituições de controle de fronteira. É Importante ressaltar que ao instituir Uruguaiana como área de segurança nacional a logística se transmuta, com o prefeito passando a ser escolhido pelo governo e reduzindo-se o espaço democrático na cidade, o que favoreceu o acobertamento das atividades repressivas.

Com a formalização desta organização internacional do terror, a estrutura foi utilizada e as ações clandestinas foram intensificadas, justificadas pelo alto número de tentativas de fugas de militantes neste local. Em geral, a Operação Condor não foi responsável por estruturar, mas sim, por intensificar e tornar mais eficiente o modo de atuação da repressão em locais específicos. No que concerne à implementação de novidades desse empreendimento repressivo, destaca-se a logística de troca de informações e colaborações que ocorreram após assinado o pacto em Santiago do Chile. Conclui-se, portanto, que faziam parte da Operação Condor as atividades operacionais de repressão política, nos anos finais da década de 1970, na região fronteiriça de Uruguaiana-Paso de los Libres. Repressão essa que caracterizou-se por uma dualidade: em parte tinha caráter normativo, e em parte discricionário. 


\section{REFERÊNCIAS}

\section{PRIMÁRIAS}

\section{1 - Argentina:}

ARGENTINA. Juzgado Federal en lo criminal y correlacional no 2 de San Martín. "Riveros, Santiago Omar y otros por la privación ilegal de la libertad, tormentos, homicídio e etc.".

ARGENTINA. Primeira Instancia de Paso de los Libres/Corrientes. Ministério Público Federal. Waern, Carlos Fidel y otros s/ supuesta comisión delitos de lesa humanidad. Expediente $n^{o}: 1.78 .239 / 04$.

ARGENTINA. Poder Judicial de la Nación. Juzgado Nacional en lo Criminal y Correccional Federal n 4. "Baca Jorge y otros s/ privación ilegal de la libertad personal. 21/09/2012.

ARGENTINA. Expte. no 16307/06. 'Guerrieri Pascual Oscar y otros s/ Privación ilegal de la libertad personal' - JUZGADO NACIONAL EN LO CRIMINAL Y CORRECCIONAL FEDERAL No 4 - 18/12/2007.

Ejército Argentino. RC-9-1: Operaciones contra elementos subversivos (Proyecto). Ejército Argentino 1975. Reservado Ejemplar número 157.

Ejército Argentino. RE - 9 - 51 Instrucción de lucha contra elementos subversivos". Buenos Aires, Ejército Argentino. 1976.

Movimento Peronista Montonero. Padre Jorge Adur: compromiso Cristiano po la liberación. Exigimos la aparición con vida del sacerdote Jorge Adur. Argentina, 1980.

PROCURADORIA GERAL DA NAÇÃO - SUPREMA CORTE. Recurso de hecho: Simón, Julio Héctor y otros s/ provación ilegítima de la libertad, etc. - causa $N^{o} 17.768$. 14-06-2005. 


\section{2 - Brasil:}

\section{Arquivos}

\section{a) Arquivo Nacional}

ACE_ACE 58818-73. Entrada e saída de brasileiros por Paso de los Libres. Informe 283/CIEx. 11/11/1973. Arquivo Nacional.

AC_ACE_93049_76. Orvandil Barbosa (Reverendo em Uruguaiana/RS). Ministério da Justiça - Departamento de Polícia Federal. Arquivo Nacional.

AC_ACE_103460_76. Dr. Ney Faria Corrêa -Cônsul do Brasil em Paso de los Libres/Argentina. Presidência da República - Serviço Nacional de Informações Agência Porto Alegre. 19/05/1976.

APA_ACE 7108_84. Professores detidos em Paso de los Libres. Porto Alegre, 26/11/1975. Ministério da Justiça Departamento de Polícia Federal Superintendência Regional no Rio Grande do Sul. Arquivo Nacional.

APA_ACE_6455_83 Ruy Barbosa de Andrade Bizarro. Porto Alegre, 18/05/1977. Ministério da Justiça Departamento de Polícia Federal Superintendência Regional no Rio Grande do Sul. Arquivo Nacional.

APA_ACE_3253_81. Alexandre Mario Berar. 02/07/1976. Presidência da República. Serviço Nacional de Informações (SNI) Agência Porto Alegre. Arquivo Nacional.

"Diante dos acordos Videla-Figueiredo o PACTO DO CONE SUL". Fundo SNI Documento AC_ACE_16680_81.

BR_AN_BSB_VAZ_021A_0090. Viagem planejada por Luiz Carlos Prestes. Ministério Aeronáutica Quarta Zona Aérea Quartel-General 2a Seção. 04 de Março de 1968. Arquivo Nacional.

BRASIL. Casa Civil da Presidência da República. Arquivo Nacional. ACE 32.368. Prisão de Jeferson Cardim e seu filho. 20/01/1971.

BRASIL. Casa Civil da Presidência da República. Arquivo Nacional. ACE L00058919. Atividades do M19 na fronteira. 01/11/1985. 
BRASIL. Casa Civil da Presidência da República. Arquivo Nacional. Correspondência do Movimento Peronista Montonero. AC_ACE 16680_81.01/06/1981.

BRASIL. BR_DFANBSB_ATO_0055_0006. Assunto: Lorenzo Ismael Viñas.

BRASIL. BR_DF_ANBSB_ATO_0048_0005. Interessado Maria Aracelia Adur. Assunto: Jorge Oscar Adur/Ārgentina. Arquivo Nacional. 1997.

BRASIL. AC_ACE_70407_80. Assunto: atuação de subversivo estrangeiro. 18 de abril de 1978.

BRASIL. Serviço Nacional de Informações. AC_ACE_5367_80. Atuação da polícia Argentina em território brasileiro - Uruguaiana/RS. 08 de dezembro de 1979.

BRASIL. Serviço Nacional de Informações. APA_ACE_878_79. Atuação da polícia Argentina em território brasileiro - Uruguaiana/RS. 28 de novembro de 1979.

CASA CIVIL PRESIDÊNCIA DA REPÚBLICA - ARQUIVO NACIONAL. Os presidentes e a ditadura militar. Rio de Janeiro, 2001.

\section{b) Arquivo Público Mineiro}

Arquivos da Polícia Política acervo do período 1927 a 1982. Movimento guerrilheiro marçoabril de 1968. Pasta 0348. Rolo 022. Documento 05. Acervo: Arquivo Público Mineiro (APM).

Arquivos da Polícia Política acervo do período 1927 a 1982. Documentações e comunicações diversas sobre presos políticos. Dezembro de 1968 - Abril de 1970. Pasta 0058. Rolo 006. Documento 329. 03/07/1969. Acervo: Arquivo Público Mineiro (APM).

Arquivos da Polícia Política acervo do período 1927 a 1982. Presos Políticos. Agosto $1969-$ Novembro de 1971. Pasta 0060. Rolo 006. Documento 238 e 239. Acervo: Arquivo Público Mineiro (APM). LAQUE, João Roberto. Pedro e os lobos: os anos de chumbo na trajetória de um guerrilheiro urbano. Vega Editora Ltda. 2010. "Orvil - Tentativas de tomada de poder" disponível em: http://www.averdadesufocada.com/images/orvil/orvil_completo.pdf

Jornal do Brasil. Jovens queriam assaltar escola e fundar "República das Rosas" em Barbacena. 05 de abril de 1968. Arquivos da Polícia Política acervo do período 1927 a 1982. Pasta 0348. Rolo 022. Documento 05. Acervo: Arquivo Público Mineiro (APM). 


\section{c) Câmara Municipal de Uruguaiana}

Câmara Municipal de Uruguaiana. $1^{\circ}$ Período Legislativo. Sessão Ordinária. Ata número 05. 08 de maio de 1980. Uruguaiana/RS.

Câmara Municipal de Uruguaiana. Ata número 10. 19 de Abril de 1968. Uruguaiana/RS.

Câmara Municipal de Uruguaiana. Ofício número 2/68. 02 de maio de 1968. Uruguaiana/RS.

Câmara Municipal de Uruguaiana. Carta Deputado Aldo Fagundes para o Presidente da Câmara Municipal de Uruguaiana Nivaldo Soares. Pasta documentos recebidos 1968. 31 de maio de 1968.

d) Ministério da Justiça - Departamento de Polícia Federal - Delegacia de Polícia Federal em Uruguaiana

Serviço Público Federal. MJ-Departamento de Polícia Federal Delegacia de Polícia Federal em Uruguaiana - DPF/UGA/RS. Inquérito policial: 0116/2008-4-DPF/UGA/RS. Folha 170. 22/06/2009.

Serviço Público Federal. Ministério da Justiça. Departamento de Polícia Federal - Divisão de Polícia Federal em Uruguaiana/RS. 28 de novembro de 1979.

\section{e) Ministério das Relações Exteriores}

BRASIL. Ministério das Relações Exteriores (MRE). Pedido de repatriação. Jacques Coimbra. Telegramas recebidos da Embaixada em Buenos Aires 1973. 08/03/1973. Acervo MRE.

BRASIL. Ministério das Relações Exteriores (MRE). Repatriação Jacques Coimbra. Telegramas recebidos da Embaixada em Buenos Aires 1973. 11/04/1973. Acervo MRE.

BRASIL. Secretaria de Estado das Relações Exteriores. Jacques de Souza Coimbra detenção. Telegramas enviados para a Embaixada em Buenos Aires 1973. 14/05/1973. Acervo MRE. 


\section{f) Ministério Público Federal. Procuradoria da República no Rio Grande do Sul}

Ministério Público Federal. Procuradoria da República no Rio Grande do Sul. PRM-URURS-00011734/2011. fls. 211.

Ministério Público Federal. Procuradoria da República no Rio Grande do Sul. PRM-URURS-00011734/2011

\section{g) Movimento Justiça e Direitos Humanos}

Resgate da Argentina. Ex-amante de militar iria morrer em 79. Jornal do Brasil. 29 de dezembro de 1991.

\section{h) Museu de Comunicação Social Hipólito José da Costa.}

Sequestro: Basta querer, em 24 horas o Delegado apurou tudo. Revista Veja, 5 de dezembro de 1979.

\section{3- Arquivos digitais}

Ata disponível em: http://www.documentosrevelados.com.br/condor-2/operacao-condor/atade-fundacao-da-operacao-condor-2/ acesso em 20 de janeiro de 2012.

CONADEP. Nunca Más. El caso de los Padres Palotinos. Disponível em: http://www.desaparecidos.org/arg/conadep/nuncamas/356.html

Documentos Revelados. http://www.documentosrevelados.com.br/condor-2/operacaocondor/documento-revela-cooperacao-entre-as-ditaduras-do-brasil-e-do-chile/

http://cidades.ibge.gov.br/xtras/perfil.php?lang=\&codmun=432240 acesso em 14 de setembro de 2014.

http://www2.transportes.gov.br/bit/02-rodo/9-pontesviadutos/pontes/pt_divisa/br_arg_uruguaiana/GPTARGBR.HTM Acesso em 20/04/2014.

Informações disponíveis em: http://www.torturanuncamaisrj.org.br/MDDetalhes.asp?CodMortosDesaparecidos=271. 
Programa Escolas Bilíngues de Fronteira. Disponível em:

http://portal.mec.gov.br/seb/arquivos/pdf/Escolafronteiras/doc_final.pdf. Março/2008.

\section{4- Imprensa}

3,6 milhões de argentinos estiveram aqui em 1980. O Jornal de Uruguaiana. Uruguaiana/RS, 31/12/1980 e 01/01/1981, número 36, ano 1. Retrospectiva 1980.

A “invasão" argentina mudou a cidade. O Jornal de Uruguaiana. Uruguaiana/RS, 31/12/1980 e 01/01/1981, número 36, ano 1. Retrospectiva 1980.

Arquivo digital do jornal argentino El País, disponível em: http://elpais.com/diario/1980/08/07/internacional/334447219_850215.html

Em um dia Uruguaiana recebeu mais de 2.500 turistas argentinos. João o Jornal do Povão. Uruguaiana/RS, 08/05/1980, número 34, ano 1.

Festivamente comemorado o $15^{\circ}$ aniversário da Revolução de 1964. Jornal Ilustrado. Uruguaiana, 05 de abril de 1979, ano 2, número 71.

Jornal do Brasil. Justiça e Paz procura padre Argentino que sumiu no Sul. 6 de agosto de 1980.

"La Polaca, un campo de concentración y exterminio en Paso de los Libres". Jornal SEPA. Capa - p. 03 -05. 19 de julio de 2004.

Muita expectativa em torno das restrições argentinas. João o Jornal do Povão. Uruguaiana/RS, 18/07/1980, número 51, ano 1.

\section{5- Legislação}

BRASIL. Diário Oficial da União. Seção I. 25 de setembro de 1944.

BRASIL. Presidência da República. Decreto No 14.666 de 06 de Dezembro de 1930. Disponível em: http:/www2.camara.leg.br/legin/fed/decret/1930-1939/decreto-19466-6dezembro-1930-561324-publicacaooriginal-84927-pe.html

Lei 5.449 de 04 de Junho de 1968. Disponível em: http://www.planalto.gov.br/ccivil_03/leis/1950-1969/L5449.htm acesso em 20/06/2014. 


\section{6- Relatórios}

Brasil. Comissão Nacional da Verdade. Mortos e desaparecidos políticos/Comissão Nacional da Verdade. Brasília: CNV, 2014. - (Relatório da Comissão Nacional da Verdade; v. 3)

Brasil. Comissão Nacional da Verdade. Relatório / Comissão Nacional da Verdade. - Brasília: CNV, 2014. Volume I. Tomo I. Parte II As estruturas do Estado e as graves violações de direitos humanos. Capítulo 5 A participação do Estado em graves violações de direitos humanos no exterior.

Brasil. Comissão Nacional da Verdade. Relatório / Comissão Nacional da Verdade. - Brasília: CNV, 2014. Volume I. Tomo II. Parte IV Dinâmica das graves violações de direitos humanos: Casos emblemáticos, locais e autores. O Judiciário. Capítulo 16. A autoria das graves violações de Direitos Humanos.

BRASIL. Relatório Comissão Nacional da Verdade (CNV) Volume III Mortos e desaparecidos políticos. Brasília: Comissão Nacional da Verdade, 2014.

BRASIL. Secretaria Especial de Direitos Humanos. Comissão Especial sobre Mortos e Desaparecidos Políticos. Direito à verdade e a memória: Comissão Especial sobre Mortos e Desaparecidos Políticos. Brasília: Secretaria de Direitos Humanos, 2007.

COMISSÃO CAMPONESA DA. VERDADE. RELATÓRIO FINAL. VIOLAÇÕES DE DIREITOS NO CAMPO. 1946 a 1988. Brasília, dezembro de 2014.

Relatório da Comissão Nacional da Verdade - GT Operação Condor com os detalhes e documentos do caso de Edmur disponível em: http://www.cnv.gov.br/images/pdf/publicacaoes/claudio/publicacoes_edmur_pericles.pdf.

Relatório final Comissão da Verdade. Mortos e Desaparecidos 1970-1971.

Relatório final Comissão da Verdade. Mortos e Desaparecidos junho de 1973- abril de 1974.

\section{SECUNDÁRIAS}

\section{1- Livros}

ASEFF, Marlon Gonsales. Retratos do exílio: solidariedade e resistência na fronteira. Santa Cruz do Sul, RS: EDUNISC, 2009. 
BELLOTO, Heloísa. Arquivos permanentes: tratamento documental. Rio de Janeiro: FGV, 2007.

BOBBIO, Norberto. A era dos direitos. Rio de Janeiro: Elsevier, 2004.

BRUNET, R. (Org.) Les mots de la Géographie - Dictionnaire critique. Montpellier-Paris, RECLUS.

CALLONI, Stella. Operación Condor: los años del lobo. 1. ed. Buenos Aires: Peña Lillo Ediciones Continente, 1999.

CALVEIRO, Pilar. Poder y desaparición: los campos de concentración en Argentina. 1. ed. 6. reimp. Buenos Aires: Colihue, 2008.

CALVEIRO, Pilar. Política y/o violencia: una aproximación a la guerrilla de los años setenta. 1. ed. Buenos Aires: Siglo Veintiuno Editores. 2013.

COGGIOLA, Oswaldo. Governos militares na América Latina. São Paulo: Contexto, 2001.

CONADEP. Nunca más: informe de la Comision Nacional sobre la Desaparición de Personas. 8. ed. 5. reimp. Buenos Aires: Eudeba, 2013.

COMBLIN, Joseph. A ideologia da segurança nacional: o poder militar na América Latina. Trad. de Veiga Fialho. 3. ed. Rio de Janeiro: Civilização Brasileira, 1980.

CUNHA, Luiz Cláudio. Operação Condor. O Sequestro dos Uruguaios. Uma reportagem dos tempos da ditadura. Porto Alegre: L\&PM, 2008.

DINGES, John. Os anos do Condor: uma década de terrorismo internacional no Cone Sul. 1 ed. São Paulo: Companhia das Letras, 2005.

DREIFUSS, René Armand. 1964: a conquista do Estado. Petrópolis, RJ: Vozes, 1986.

DUHALDE, Eduardo Luis. El Estado terrorista argentino. 1. ed. Ciudad Autónoma de Buenos Aires: Colihue, 2013.

FAORO, Raymundo. Os donos do poder. São Paulo: Editora Globo/EDUSP, 1975. v. 2. 
FOUCHER, M. (1989). Fronts et frontières - Un tour du monde géopolitique. Paris: Fayard, 1991.

GARAÑO, Santiago; PERTOT, Werner. Detenidos-aparecidos. 1. ed. Buenos Aires: Biblos, 2007.

GARULLI, Liliana; CHARLIER, Noemí; CARABALLO, Liliana, M. Dictadura (19761983): testemonios y documentos. Buenos Aires: Eudeba, 2011.

GASPARINI, Juan. Montoneros: final de cuentas. 2. ed. 1. reimp. La Plata: De la Campana, 2008.

GOTTMANN, J. (1973). The significance of territory. Charlottesville: University Press of Virginia, 1992.

GRIMSON, A. La nación en sus límites - Contrabandistas y exilados en la frontera Argentina-Brasil. Barcelona: Editorial Gedisa S/A, 2003.

GOFFMAN, E. Estigma: notas sobre a manipulação da identidade deteriorada. 4. ed. Rio de Janeiro: Zahar, 1988.

GUAZZELLI, Cesar Augusto Barcellos. História Contemporânea da América Latina: 1960-1990. 2. ed. Porto Alegre: Editora da UFRGS, 2004.

GUERRA, C.; NETTO, M.; MEDEIROS, R. Memórias de uma guerra suja. Rio de Janeiro: Topbooks, 2012.

GUGLIALMELLI, Juan. Argentina-Brasil: enfrentamiento o alianza para la liberación. Estratégia, Buenos Aires, n. 36, 1975.

IANNI, Octavio. Imperialismo e cultura. Petrópolis, RJ: Vozes, 1976.

LEAL, Vitor Nunes. Coronelismo, enxada e voto. São Paulo: Editora Alfa-Omega, 1976.

MARIANO, S. Nilson. As garras do Condor: como as ditaduras militares da Argentina, do Chile, do Uruguai, do Brasil, da Bolívia e do Paraguai se associaram para eliminar adversários políticos. Petrópolis, RJ: Vozes, 2003. 
MARTORELL, Francisco. Operación Cóndor: el vuelo de la muerte. Santiago: LOM Ediciones, 1999.

MITCHELL, José. Segredos à direita e à esquerda na ditadura militar. Porto Alegre: RBS Publicações, 2007.

MOTTA, Rodrigo Patto Sá. Em guarda contra o perigo vermelho: o anticomunismo no Brasil (1917-1964). São Paulo: Perspectiva, 2002.

NOVARO, Marcos; PALERMO, Vicente. A Ditadura Militar argentina 1976-1983: do golpe de Estado à restauração democrática. São Paulo: Editora da Universidade de São Paulo, 2007.

O’DONNELL. Guillermo. Contrapuntos: ensayos escogidos sobre autoritarismo y democratización. Buenos Aires: Paidós, 2004.

PADRÓS, Enrique Serra; VIVAR, Jorge Eduardo Enríquez. Memórias da Resistência e da Solidariedade: o Movimento de Justiça e Direitos Humanos contra as ditaduras do Cone Sul e sua conexão repressiva. Porto Alegre: Ed. ASF, 2013.

PELLEGRINI, Enrique. Paso de los Libres: crónicas y ensayos. Buenos Aires: López Libreros, 1974.

RAFFESTIN, C. (1980). "O território e o poder" In: Por uma geografia do poder. São Paulo: Ática, 1993.

ROMERO, A. Luis. História Contemporânea da Argentina. Rio de Janeiro: Jorge Zahar Ed. 2006.

RUBIO, Gladis Dora Mango; AGUIRRE, Delia Antonia Guadalupe. Paso de los Libres: história, espacio y memoria. 1. ed. Corrientes: Moglia Ediciones, 2007.

SARLO, Beatriz. Tempo presente: notas sobre a mudança de uma cultura. Rio de Janeiro: José Olympio, 2005.

SARLO, Beatriz. La pasión y la excepción. 1. ed. Buenos Aires: Siglo Veinteuno Editores, 2003.

SILVA, Golbery C. Geopolítica do Brasil. Rio de Janeiro: José Olympio, 1967. 
SINGLY, F. O eu, o casal e a família. Trad. de Magda Bigotte Figueiredo. Lisboa: Publicações Dom Quixote, 2000.

STARLING, Heloísa Maria Gurgel. Os senhores das gerais: os novos inconfidentes e o golpe de 1964. Petrópolis, RJ: Vozes, 1986.

TARRUELA, Alejandro C. El largo adiós de los montoneros: de las sombras de los setenta al presente kirchnerista. Buenos Aires: Javier Vergara Editor, 2012.

TÉRCIO, Jason. A espada e a balança: crime e política no banco dos réus. Rio de Janeiro. Jorge Zahar Editor, 2002.

TURNER, Frederick Jackson. The frontier in american history. New York: Dover, 1996.

VEZZETTI. Hugo. Pasado y presente: guerra, dictadura e sociedade en la Argentina. Buenos Aires: Siglo Veintiuno Editores, 2009a.

. Sobre la violencia revolucionaria: memorias y olvidos. Buenos Aires: Siglo Veintiuno Editores, 2009b.

VILLALOBOS, Sergio R. Breve historia de Chile. Santiago do Chile: Editorial Universitaria S.A., 1983.

WORNAT, Olga. Nuestra Santa Madre. historia pública y privada de la Iglesia Católica Argentina. Buenos Aires: Ediciones B, 2002.

ZARANKIN, Andrés; NIRO, Claudio. La materialización del sadismo. Arqueologia de la arquitectura de los Centros Clandestinos de Detención de la dictadura militar argentina (19761983). In.: ZARANKIN, Andrés; FUNARI, Pedro Paulo (Comp.). Arqueologia de la represión y la resistência en America Latina: 1960-1980. Córdoba: Encuentro Grupo Editor, 2006.

\section{2 - Capítulos de livros}

AGUIRRE, D. Cuando en Paso de los Libres habia Puerto. IN.: RUBIO, Gladis Dora Mango; AGUIRRE, Delia Antonia Guadalupe. Paso de los Libres: História, espacio y memoria. $1^{\mathrm{a}}$ ed. Corrientes: Moglia Ediciones, 2007. 
ANTUNES, Priscila. Ditaduras militares e institucionalização dos serviços de informações na Argentina, no Brasil e no Chile. In.: FICO... [et al.] Ditadura e democracia na América Latina: balanço histórico e perspectivas. Rio de Janeiro: Editora FGV, 2008.

BORGES, Nilson. A Doutrina de Segurança Nacional e os governos militares. In.: FERREIRA, Jorge e DELGADO, Lucília de A. N. O tempo da ditadura: regime militar e movimentos sociais em fins do século $X X$. Rio de Janeiro: Civilização Brasileira, 2009. (O Brasil Republicano; v.4).

CATELA, Ludmila da Silva. O mundo dos arquivos. In.: REATEGUI, Felix (Org.), Justiça de Transição - Manual para a América Latina. Brasília/Nova Iorque: Ministério da Justiça/ICTJ, 2011. p. 379-401.

CASTELLO, R. Iara. Áreas de fronteira: Territórios de integração, espaços culturalmente identificados? In.: CASTELLO, R. Iara; HAUSEN, C. Ennio et tal. Práticas de integração nas fronteiras: temas para o MERCOSUL. Porto Alegre: Ed. da Universidade/UFRGS, Instituto Goethe/ICBA, 1995.

FERNÁNDEZ, Jorge Christian. O exílio argentino no sul do Brasil e a conexão binacional repressiva entre Argentina e Brasil. In.: PADRÓS, Enrique Serra (org). Cone Sul em tempos de ditadura: reflexões e debates sobre a história recente. Porto Alegre: Evangraf/UFRGS, 2013.

FICO, Carlos. O golpe de 1964 e o papel do governo dos EUA. In.: FICO, Carlos... [et al.] org. Ditadura e Democracia na América Latina. Rio de Janeiro: Editora FGV, 2008.

FRANK, Robert. Questões para as fontes do presente. In: CHAUVEAU, Agnès; TÉTART, Philippe (org.). Questões para a história do presente. Bauru, SP: EDUSC, 1999.

HOBSBAWM, Eric. O presente como História. In: HOBSBAWM, Eric. Sobre história. São Paulo: Companhia das Letras, 1998.

KRISCHKE, Jair. O Brasil inspirou a Operação Condor. In.: SILVA, Haike R. Kleber (org.). A luta pela anistia. São Paulo: IMESP, 2010.

KNAUSS, Paulo; OLIVEIRA, Camila Costa. Usos do passado e arquivos da polícia política. In.: QUADRAT, Samantha Viz (org.). Caminhos cruzados: história e memoria dos exílios latino-americanos no século XX. Rio de Janeiro: Editora FGV, 2011. pp. 289-300. 
LAFFONT, Roberto; MEYER, Philippe. O exemplo da Argentina. In.: TOSI, Giuseppe; FERREIRA, Lúcia de Fátima (orgs.). Contrarrevolução na América Latina: subversão military e instrumentalização dos sindicatos, da cultura, das Igrejas -Tribunal Russell II. João Pessoa: Editora UFPB, 2014.

PA, Alfredo Boccia. Los “archivos del horror"del Paraguay: los papeles que resignificaron la memoria del stronismo. In.: FICO... [et al.] Ditadura e democracia na América Latina: balanço histórico e perspectivas. Rio de Janeiro: Editora FGV, 2008.

PADRÓS, Enrique Serra; MARÇAL, Fábio Azambuja. O Rio Grande do Sul no cenário da coordenação repressive de segurança nacional. In.: PADRÓS... [et. al.] Ditadura de Segurança Nacional no Rio Grande do Sul (1964-1985): História e Memória. 2a ed., rev. e ampl. Porto Alegre: Corag, 2010 -V. 3.

, Enrique Serra. Repressão e violência: segurança nacional e terror de Estado nas ditaduras latino-americanas. In.: FICO... [et al.] Ditadura e democracia na América Latina: balanço histórico e perspectivas. Rio de Janeiro: Editora FGV, 2008.

, Enrique Serra. Conexão repressiva internacional: o Rio Grande do Sul e o Brasil na rota do Condor. In: PADRÓS, Enrique Serra et al. (orgs.). A ditadura de Segurança Nacional no Rio Grande do Sul (1964-1985): história e memória. Conexão Repressiva e Operação Condor. Porto Alegre: Corag, 2009. v. 3.

, Enrique S. A história e a memória confiscada: o tempo presente e as ditaduras de segurança nacional. In: Clínicas do Testemunho: reparação psíquica e construção de memórias. Porto Alegre: Criação Humana, 2014.

QUADRAT, Samantha V. A ditadura civil-militar em tempo de (in)definições (1964-1968). In.: MARTINHO, Francisco C. P. Democracia e ditadura no Brasil. Rio de Janeiro: EdUERJ, 2006.

, Samantha Viz. Da Argentina para o Brasil: de uma ditadura a outra. In.: QUADRAT, Samantha Viz (org.). Caminhos cruzados: história e memoria dos exilios latinoamericanos no século XX. Rio de Janeiro: Editora FGV, 2011. pp.169-204.

RUBIO, G. Paso de los Libres una reivindicación a la libertad. IN.: RUBIO, Gladis Dora Mango; AGUIRRE, Delia Antonia Guadalupe. Paso de los Libres: História, espacio y memoria. $1^{\mathrm{a}}$ ed. Corrientes: Moglia Ediciones, 2007.

RUBIO, G.; GUADALUPE, D. La singularidade del Paso. IN.: RUBIO, Gladis Dora Mango; AGUIRRE, Delia Antonia Guadalupe. Paso de los Libres: História, espacio y memoria. $1^{\mathrm{a}}$ ed. Corrientes: Moglia Ediciones, 2007. 
VICENTE, Maria de Fátima. Violência de Estado e resistência (s). In.: OCARIZ, Maria Cristina (org). Violência de Estado na ditadura civil-militar brasileira (1964-1985): efeitos psíquicos e testemunhos clínicos. São Paulo: Escuta, 2015.

YANKELEVICH, Pablo. Estudar o exílio. In.: QUADRAT, Samantha Viz (org.). Caminhos cruzados: história e memoria dos exílios latino-americanos no século XX. Rio de Janeiro: Editora FGV, 2011. pp.11-30.

\section{3- Dissertações e teses}

AVILA, Arthur Lima de. E da fronteira veio um pioneiro: a frontier thesis de Frederick Jackson Turner (1861-1932). Dissertação de Mestrado - PPGHIST/UFRGS, Porto Alegre, 2006.

BAUER, Caroline Silveira. Avenida João Pessoa, 2050 - 3 o andar: Terrorismo de Estado e ação de polícia política do Departamento de Ordem Política e Social do Rio Grande do Sul (1964-1982). Dissertação de mestrado Programa de Pós-Graduação em História da Universidade Federal do Rio Grande do Sul. UFRGS, Porto Alegre, 2006.

COSTA, Alex Jacques. Seguindo ordens, cruzando campos: o governador e capitão general Dom Diogo de Souza e a política do Império Português para o Rio da Prata (1808 - 1811). Dissertação de mestrado. Pontifícia Universidade Católica do Rio Grande do Sul - PUCRS. Porto Alegre, 2010.

CHINDEMI, Julia Valeria. Las tradiciones de frontera internacional em Rio Grande del Sur: un análisis em la larga duración. Dissertação de Mestrado. UnB. 1999.

DÁVILA, Maria de Lourdes Brondani. A ponte internacional Brasil-Argentina: limites e possibilidades da política de boa vizinhança. Dissertação de Mestrado. Pós-Graduação em História. IFCH Pontifícia Universidade Católica do Rio Grande do Sul. PUCRS. Porto Alegre, 1994.

FERNANDEZ, Jorge C. Anclaos en Brasil: a presença argentina no Rio Grande do Sul (1966-1989). Porto Alegre: UFRGS, 2011 Tese (Doutorado em História) - Programa de PósGraduação em História da UFRGS. Universidade Federal do Rio Grande do Sul, Porto Alegre, 2011.

GARCIA, Graciela Bonassa. O domínio da terra: conflitos e estrutura agrária na campanha rio- grandense oitocentista. Dissertação de Mestrado - UFRGS, Porto Alegre, 2005. 
MARIANO, S. Nilson. Montoneros no Brasil - Terrorismo de Estado no seqüestrodesaparecimento de seis guerrilheiros argentinos. Porto Alegre: PUCRS, 2006. Dissertação, Mestrado em História - PUCRS. Porto Alegre, 2006.

MORAES, Thiago Aguiar de. "Entreguemos a emprêsa ao povo antes que o comunista a entregue ao Estado": os discursos da fração "vanguardista" da classe empresarial gaúcha na revista "Democracia e Emprêsa" do Instituto de Pesquisas Econômicas e Sociais do Rio Grande do Sul (1962-1971). 2012. Dissertação (Programa de Pós-Graduação em História) Pontifícia Universidade Católica do Rio Grande do Sul, Porto Alegre.

PADRÓS, Enrique Serra. Como el Uruguay no hay...Terror de Estado e Segurança Nacional - Uruguai (1968-1985): do Pachecato à Ditadura Civil-Militar. Porto Alegre: UFRGS, 2005. Tese, Doutorado em História - UFRGS. Porto Alegre, 2005.

PASCUAL, Alejandra L. Terrorismo de Estado - A Argentina de 1976 a 1983.Florianópolis: UFSC, 1997. Tese, Doutorado em Direito - UFSC. Florianópolis, 1997.

REIS, Ramiro José. Operação Condor e o sequestro dos uruguaios nas ruas de um porto não muito alegre. Porto Alegre: UFRGS, 2012 Dissertação (Mestrado em História) - Programa de Pós-Graduação em História da UFRGS. Universidade Federal do Rio Grande do Sul, Porto Alegre, 2012.

STEINKE, Sabrina. Agentes da Ditadura Argentina nos trilhos da Justiça: embates diante de um processo crime de lesa humanidade. Porto Alegre: PUCRS, 2010. Dissertação, Mestrado em História - PUCRS. Porto Alegre. 2010.

THOMPSON FLORES, Mariana F. da C. Crimes de fronteira: a criminalidade na fronteira meridional do Brasil (1845-1889). Porto Alegre: PUCRS, 2012. Tese de doutorado em História. Programa de Pós-Graduação em História PUCRS.

\section{4- Artigos}

CAMPOS, Esteban. Memoria, ensayos y polémicas. El balance de la experiencia montonera en los años 1980. Topoi, V.14, n 26, Jan/Jul 2013, p. 6-17.

CERVEIRA, Neusa R. P. Rumo à Operação Condor-Ditadura, tortura e outros crimes. Projeto História, São Paulo, no 38, p. 97-118. Junho de 2009.

COLVERO, Ronaldo Bernardino e SOARES, Luiz Francisco Matias. Uruguaiana: a estância como fronteira. Estudios históricos - CDHRP. No 3. Deciembre de 2009. 
FERNANDES, Ananda S. A perseguição além fronteira: os orgãos de repressão $e$ espionagem da ditadura brasileira para o controle dos exilados no Uruguai. Estudios Historicos, $\mathrm{n}^{\circ}$ 1. CDHRP. Mayo 2009.

FERNANDEZ, Jorge C. A banalização da Operação Condor: o estranho caso de Cristina Fiori de Vina, novembro de 1979. In: XXVI Simpósio Nacional de História: Anpuh 50 anos, 2011, São Paulo. Anais do XXVI Simpósio Nacional da Anpuh - Associação Nacional de História. São Paulo: ANPUH-SP, 2011.

MELLO, S. L. A identidade uma tentativa de aproximação. In: Anais do I Encontro Interdisciplinar Sobre Identidade. São Paulo: Boletim do Grupo de Pesquisa sobre Identidade Social, 1983.

ROMERO, Luis A. A memória, o historiador e o cidadão. A memória do Proceso argentino e os problemas da democracia. TOPOI, v.8, n. 15, jul.-dez. 2007, p. 9-23.

SACCHETTI, F. E. Antônio. Fronteiras - novos conceitos questões fronteiriças. Grupo de estudo e reflexão estratégica. Cadernos Novais. $N^{0}$ 6. Jul-Set. 2003. Edições Culturais da Marinha. Lisboa.

STEINKE, Sabrina. Fronteira Brasil-Argentina, relações estabelecidas por meio de uma prisão clandestina. Revista Múltipla - Ano XVII - vol. 26 - no 34, junho de 2013.

, Sabrina. Apontamentos sobre a transição democrática argentina. Anais do XXVI Simpósio Nacional de História. ANPUH. São Paulo, julho de 2011. p.8.

QUADRAT,Samantha Viz. Operação Condor: o "Mercosul" do Terror. Estudos IberoAmericanos. PUCRS, v. XXVIII, n.1, p. 167-182. Porto Alegre. Junho 2002.

, Samantha Viz. Memórias do exílio argentino no Brasil. X Encontro Nacional de História Oral. Testemunhos: História e Política. Universidade Federal de Pernanbuco (UFPE) Centro de Filosofia e Ciências Humanas. Recife/PE. 26-30 de abril de 2010.

\section{5- Jornais e revistas}

DIDI-HUBERMAN, Georges. Georges Didi-Huberman: “yo no se lo que es arte”. Entrevista realizada por Cecília Macón. La Nación, ADN Cultura, 31 de outubro de 2014. 
FERNANDÉZ, Jorge C. Resistir es vencer: o Brasil e a Contraofensiva Montonera, 19781980. In.: PADRÓS, Enrique S (org.) Dossiê Ditaduras de Segurança Nacional no Cone Sul. Revista do Programa de Pós-Graduação em História. v. 19. no 35, Porto Alegre: PPGH, jul. 2012.

"Hermanos" por Abdias Silva. Jornal Correio do Povo, quarta-feira, 21 de maio de 1947. Disponível em: http://www.cpovo.net/jornal/A114/N236/HTML/Seculo.htm acesso em 12 de janeiro de 2014 às $9 \mathrm{~h}$.

Los desastres en que la dictadura ha sumergido al país ya inundan los despachos militares. Revista Estrella Federal. Número 05. Setembro/1978.

Montoneros: Resumen de la campaña. Revista Evita Montonera, ano2, $\mathrm{n}^{\mathrm{o}}$ 13, abril-maio de 1976.

Preparar la contraofensiva. Revista Estrella Federal. Número 05. Setembro/1978.

QUINTANA, G. A. Archives of the Security Services of Former Repressive Regimes". Janus, $\mathrm{N}^{\mathrm{o}} 2,1998$, p. 7-23.

Sobrevivente de ação clandestina da Operação Condor conta detalhes sobre sequestro de argentina em Uruguaiana. Jornal Zero Hora. 25 de maio de 2013. Disponível em: http://zh.clicrbs.com.br/rs/noticias/noticia/2013/05/sobrevivente-de-acao-clandestina-daoperacao-condor-conta-detalhes-sobre-sequestro-de-argentina-em-uruguaiana-4148644.html

\section{6- Sites}

http://www.viomundo.com.br/politica/luiz-claudio-cunha-as-garras-do-brasil-na-operacaocondor.html acesso em 08 de Julho de 2012.

http://operamundi.uol.com.br/conteudo/noticias/30470/operacao+condor+neto+resgatado+pel as + avos + da + praca + de + maio + e + filho + de + chilenos + .shtml acesso em 08 de agosto de 2013 às 9h.

http://www.urgente24.com/208030-baltasar-garzon-que-la-sombra-de-noemi-molfino-lealcance.

http://www.uruguaiana.rs.gov.br.

http://www.radiolt12.com.ar/vernota.asp?id_noticia=56367 acesso em 13 de janeiro de 2014. 
STF aprova pedido de extradição de terrorista francês. Diário do Grande ABC. 16/06/2000. Disponível em: http://www.dgabc.com.br/Noticia/313406/stf-aprova-

http://www.cuco.com.ar/garrincha.htm

https://www.fiscales.gob.ar/lesa-humanidad/batallon-de-inteligencia-601-juicio-oral-contratres-represores-por-secuestros-extorsivos/ 
ANEXOS 